\title{
A CAPACIDADE NORMATIVA DE CONJUNTURA NO DIREITO ECONÔMICO: O DÉFICIT DEMOCRÁTICO DA REGULAÇÃO FINANCEIRA
}

Tese apresentada à Faculdade de Direito da Universidade de São Paulo (USP), sob a orientação do Prof. Dr. Eros Roberto Grau, como requisito parcial para a obtenção do título de Doutor em Direito Econômico e Financeiro.

Candidato: Jean Paul Cabral Veiga da Rocha

\author{
Universidade de São Paulo \\ Faculdade de Direito \\ Depto. de Direito Econômico e Financeiro
}

São Paulo, junho de 2004 
Banca Examinadora 
Para Elô. 
"Under a democratic form of state capitalism, the state [...] is based on institutions which prevent the bureaucracy from transforming its administrative position into an instrument of power and thus laying the basis for transshaping the democratic system into a totalitarian one."

Frederick Pollock, "State Capitalism"

"The passing of market-economy can become the beginning of an era of unprecedented freedom. Juridical and actual freedom can be made wider and more general than ever before; regulation and control can achieve freedom not only for the few, but for all. Freedom not as an appurtenance of privilege, tainted at the source, but as a prescriptive right extending far beyond the narrow confines of the political sphere into the intimate organization of society itself. Thus will old freedoms and civic rights be added to the fund of new freedom generated by the leisure and security that industrial society offers to all. Such a society can afford to be both just and free"

Karl Polanyi, The Great Transformation 


\section{AGRADECIMENTOS}

Tive, ao longo dos últimos onze anos, desde quando iniciei os primeiros estudos para meu projeto de iniciação científica, financiado também pela FAPESP, o privilégio de ter como orientador o Professor Eros Roberto Grau, que parte agora para uma nova e especial missão pública: o exercício da interpretação autêntica do direito no Supremo Tribunal Federal. Sua visão interdisciplinar e progressista do Direito Econômico e seu pioneirismo no desenvolvimento, entre nós, da nova hermenêutica, deixaram marcas indeléveis na minha formação. A origem do presente trabalho está nas suas instigantes aulas no curso de pós-graduação sobre a "capacidade normativa de conjuntura no Direito Econômico", que desde o meu terceiro ano da Faculdade ele gentilmente me permitia assistir. Foi graças também aos inúmeros projetos acadêmicos que ele coordenou que eu tive a oportunidade de participar de seminários com Michel Troper, Mario Losano, Michel Miaille, Franck Moderne e Gérard Marcou, dentre outros importantes nomes do direito contemporâneo - oportunidade que contribuiu imensamente para o presente trabalho. Não posso deixar de agradecer também pela oportunidade que tive, durante três semestres, de atuar como monitor da disciplina Direito Econômico no curso de graduação, sob sua supervisão, no âmbito do estágio do Programa de Aperfeiçoamento do Ensino da USP (PAE-USP).

Este trabalho pôde ser realizado graças também ao apoio de instituições, professores, amigos e familiares. Gostaria, portanto, de agradecer:

Aos colegas do Núcleo Direito e Democracia do CEBRAP, especialmente aos coordenadores do projeto, professores Ricardo Terra e Marcos Nobre. Os seminários que realizamos ao longo dos últimos anos, sob a sua orientação, foram fundamentais para minha formação e decisiva para a elaboração desta tese. Tenho encontrado no CEBRAP, desde quando fui bolsista do seu Programa de Formação de Quadros Profissionais, sob a orientação acadêmica do Prof. José Arthur Giannotti, um ambiente plural de intensa provocação intelectual, que tem influenciado imensamente minhas atividades de pesquisa e ensino.

A todos aqueles que colaboraram para viabilizar minha temporada como Visiting Scholar na Yale Law School, onde pude concluir minha pesquisa e a redação da tese em meio a um ambiente acadêmico no mínimo excitante e extraordinárias condições de trabalho. A Paulo Todescan Lessa Mattos e Caio Mário da Silva Pereira Neto, um agradecimento especial pelo apoio e pelas discussões que temos tido, nos últimos anos, sobre os dilemas e tensões do Estado Regulador brasileiro.

À Fundação de Amparo à Pesquisa do Estado de São Paulo (FAPESP) pelo indispensável apoio financeiro, e ao seu consultor ad hoc, pelas críticas e sugestões apresentadas durante a vigência da bolsa. 
À Escola de Direito de São Paulo da Fundação Getulio Vargas (FGV-EDESP), na figura de seu diretor, Prof. Ary Oswaldo Mattos Filho, e de seus vice-diretores, Prof. Antonio Angarita e Prof. Paulo Goldschmitt, pelo apoio institucional que permitiu meu afastamento para conclusão da tese e pelo constante estímulo. Aos colegas da mesma Escola, em especial ao Prof. Esdras Borges Costa, querido companheiro dos estudos de metodologia do ensino, pelas empolgantes discussões sobre jurisprudência e pelos comentários aos estudos de casos da tese. Agradecimento especial também a Conrado Hübner Mendes e Luciana Gross Cunha, que assumiram importantes projetos na Escola durante minha ausência.

Aos professores Mônica Hermann e Régis Fernandes de Oliveira, integrantes da Banca do Exame de Qualificação, pelas críticas e sugestões apresentadas ao projeto de pesquisa, que procurei ao máximo incorporar no trabalho.

Ao professor Carlos Ari Sundfeld e aos colegas da Sociedade Brasileira de Direito Público (SBDP), pela oportunidade de discutir várias das idéias aqui desenvolvidas num ambiente de grande estímulo e liberdade intelectual,

Aos professores José Eduardo Faria, Ronaldo Porto Macedo Jr. e José Reinaldo de Lima Lopes, e aos colegas do Projeto PET-CAPES da Faculdade de Direito da USP, do qual fui bolsista, pelo estímulo intelectual constante nos seminários que também contribuíram enormemente para minha formação.

Aos professores Jerry Mashaw, Susan Rose-Ackerman e Barbara Safriet, da Yale Law School, pelos comentários e sugestões que me levaram a repensar uma série de pontos importantes do trabalho.

A Otávio Yazbek, Tiago Cortez, Diogo Coutinho e José Rodrigo Rodriguez, pelo diálogo acadêmico de alto nível e pelo apoio imprescindível nos últimos meses da redação.

A Camila Duran Ferreira, minha assistente de pesquisa, pelo trabalho incessante e competente de levantamento de dados e de decisões judiciais.

A Mariana Prado e Márcio Grandchamp, pela gentil acolhida em New Haven e nos encontros acadêmicos de Yale.

A Virgílio Afonso da Silva e Marco Aurélio Sampaio, pelas nossas intermináveis discussões sobre a separação dos poderes.

A Valdenberg e Maria Luísa, pelo apoio e estímulo extraordinários, desde o começo.

A meus pais, Cícero e Tereza, e aos pais da Eloá, Valentim e Maria Joana, pelo apoio durante todos esses anos, e especialmente nos últimos três meses.

A Eloá, que participou e participa de tudo na minha vida, a ela dando sentido. E ao Guilherme, que me enche de esperança.

Por fim, gostaria de dedicar esse trabalho à memória de José Resende Pacheco e de meu avô, João Cícero Laurentino da Rocha. 


\section{SUMÁRIO}

Introdução

$\begin{array}{llllll}\text { Capítulo I } & \text { REGULAÇÃO } & \text { FINANCEIRA } & \text { E } & \text { DIREITO PÚBLICO } & 11\end{array}$ BRASILEIRO

1. Estado de mãos atadas: a doutrina clássica da separação dos poderes 11

2. A peculiaridade da regulação financeira: a moeda como instituição 36 social

3. O déficit democrático da regulação financeira 64

Capítulo II SEPARAÇÃO DOS PODERES E $\quad$ CONTROLE 71 DEMOCRÁTICO

1. Da constituição-norma à constituição-máquina: a separação dos poderes 71 como equilíbrio

2. Separação dos poderes e democracia deliberativa 86

3. A máquina em movimento: o controle judicial da burocracia 108

$\begin{array}{lll}\text { Capítulo III ESTUDO DE CASOS } & 116\end{array}$

1. Quatro dificuldades para a análise da jurisprudência constitucional 116

2. A tensão entre racionalidades 125

3. Os poderes normativos da burocracia: reconhecimento sem controle 143

4. Controle judicial e participação democrática 164

5. Controle de constitucionalidade, burocracia e democracia deliberativa 171

$\begin{array}{lll}\text { Capítulo IV DIREITO ECONÔMICO E DEMOCRACIA } & 175\end{array}$

1. O falso consenso: a construção dos cânones do direito público brasileiro 175

2. Para além do controle judicial: constituição máquina e imaginação 191 constitucional

$\begin{array}{ll}\text { BIBLIOGRAFIA } & 196\end{array}$

$\begin{array}{ll}\text { RESUMÉ } & 203\end{array}$

$\begin{array}{ll}\text { ABSTRACT } & 204\end{array}$ 


\section{INTRODUÇÃO}

A regulação financeira, especialmente a regulação bancária, tem um papel central na organização a vida social. As modernas técnicas regulatórias, altamente sofisticadas, são o resultado de décadas de evolução. Elas exigem técnicos especializados, orçamentos específicos e uma estrutura institucional complexa. Mais que isso: para promover as regulações sistêmica e prudencial, os reguladores necessitam de amplos poderes normativos - uma capacidade normativa de conjuntura.

A atribuição de tais competências a órgãos que não contam com a legitimidade das urnas é considerada por alguns autores uma espécie de anomalia no Direito Constitucional. Para outros, ao contrário, ela é um elemento necessário do desenho institucional do Estado Regulador contemporâneo. É nesse ponto que se cruzam os debates sobre o processo de burocratização da vida social e sobre o desenvolvimento dos cânones do direito ocidental, especialmente a doutrina da separação dos poderes.

A juridificação das esferas sociais suscita o tema do déficit democrático da formulação de políticas pela burocracia. A presente tese desenvolve, a partir do modelo de democracia deliberativa de Jürgen Habermas, a premissa normativa segundo a qual o controle judicial é necessário para garantir a legitimidade democrática do processo administrativo normativo. Como o cidadão comum não dispõe nem do conhecimento técnico nem dos meios materiais necessários para acompanhar o processo de tomada de decisões, o controle judicial deveria funcionar como um mecanismo de controle democrático da regulação financeira.

A tese analisa esse déficit democrático a partir da jurisprudência constitucional do Supremo Tribunal Federal (STF) relativa à separação dos poderes e às disputas doutrinárias sobre delegação legislativa e poder regulamentar. Os estudos de caso, focados no sistema financeiro, buscam investigar se a atuação do STF tem garantido de forma adequada um equilíbrio entre a racionalidade tecnocrática e as exigências normativas de uma democracia deliberativa. 
Dentro dessa proposta da análise, qual pode ser o papel do pensamento jurídico? Para utilizar a consagrada terminologia de $\mathrm{Hart}^{1}$, uma análise do ponto de vista interno limitar-se-ia a descrever o regime jurídico do Conselho Monetário Nacional e do Banco Central do Brasil, analisar a constitucionalidade e a legalidade das normas produzidas por esses órgãos etc. Já uma análise do ponto de vista externo ocupar-se-ia, por exemplo, do papel da elite da burocracia econômica na reformulação do sistema financeiro nacional a partir do golpe de 64. A tradição positivista sempre confinou o direito naquela primeira perspectiva, interna. Alguns sociólogos têm insistido no extremo oposto.

O presente projeto parte da premissa segundo a qual é tarefa do pensamento jurídico superar essa dicotomia. Tenta, portanto, acompanhar essa proposta metodológica, nos seguintes termos:

(a) No âmbito dogmática do direito público brasileiro, realizar uma análise do ponto de vista interno (formal) do poder regulamentar do $\mathrm{CMN}$ e do $\mathrm{BCB}$, à luz do princípio da separação dos poderes, combinando perspectivas clássicas e contemporâneas debates clássicos as noções de lei em sentido formal, lei em sentido material, norma, regulamento, delegação legislativa, dentre outras;

(b) Numa perspectiva interdisciplinar, discutir, a partir da concepção de moeda enquanto instituição social - e não uma mera mercadoria --, a relação da separação dos poderes com os princípios liberal e democrático, a legitimidade da regulação financeira, a tensão entre democracia e tecnocracia, entre racionalidade formal e racionalidade material;

(c) Articular as duas linhas de pesquisa numa análise do poder regulamentar das autoridades monetárias brasileiras após a Constituição de 1988, a partir das seguintes hipóteses de trabalho:

(i) a "separação dos poderes" foi e continua sendo um mito, pelo menos para o pensamento jurídico-político dominante;

\footnotetext{
${ }^{1}$ The Concept of Law, 2nd. ed., Oxford University Press, 1994, p. 89.
} 
(ii) a dinâmica do capitalismo contemporâneo exige uma atividade normativa de conjuntura (o mercado financeiro não pode esperar uma normatização oriunda do Legislativo), o que torna irrealista essa doutrina tradicional;

(iii) a centralização de poderes normativos na burocracia econômica, afeta, em tese, o princípio liberal e o princípio democrático;

(iv) só uma nova concepção - realista - do regulamento, que rompa com a visão tradicional da separação dos poderes tem condições de viabilizar, ao mesmo tempo, a compreensão da nova realidade jurídica, e a criação de meios (interpretação jurídica e reforma institucional) de defesa do indivíduo contra a atuação estatal e de controle democrático da regulação financeira. 


\section{CAPÍTULO I}

\section{REGULAÇÃO FINANCEIRA E DIREITO PÚBLICO BRASILEIRO}

1. O Estado de mãos atadas: a doutrina clássica da separação dos poderes

A crescente atuação do Estado sobre a economia, representada pelo fenômeno da “inflação normativa", ${ }_{1}^{1}$ deixa perplexa a doutrina jurídica tradicional, fortemente apegada a postulados do constitucionalismo clássico.

O princípio da separação dos poderes, elevado à condição de verdadeiro mito do Estado de Direito, serve de couraça a um pensamento jurídico-político que reluta em aceitar a constitucionalidade das normas editadas por órgãos do Poder Executivo. Dentre estes, ocupam lugar especial o Conselho Monetário Nacional (CMN) e o Banco Central do Brasil (BCB), criados no bojo da modernização autoritária promovida durante o regime político instaurado em 1964.

Dotados de numerosas competências, definidas principalmente na Lei de Reforma Bancária de 1964 (Lei no 4595/64)², esses dois órgãos governamentais editam, em curtos lapsos, um grande número de normas que regulamentam uma infinidade de transações ${ }^{3}$ econômicas, alterando desde a política monetária até os contratos de consórcio. Esse seu poder normativo, apesar da contestação oriunda da doutrina jurídica dominante, é efetivo — os agentes econômicos e os órgãos estatais respeitam e acatam essas normas.

\footnotetext{
${ }^{1}$ A expressão é utilizada por Eros Roberto Grau (“Crítica e defesa da legalidade”, in $O$ direito posto e $o$ direito pressuposto, São Paulo: Malheiros, 1996, p. 136). Como registra o autor, foi Carnelutti quem primeiro fez a analogia com a inflação monetária, ao cunhar a expressão "inflação legislativa".

2 Por exemplo: disciplinar o crédito e as operações creditícias em todas as suas formas; determinar a percentagem máxima dos recursos que as instituições financeiras poderão emprestar a um mesmo cliente ou grupo de empresas; regulamentar as operações de redesconto e de empréstimo efetuadas com quaisquer instituições financeiras públicas e privadas de natureza bancária; estatuir normas para as operações das instituições financeiras públicas; regulamentar as operações de câmbio, inclusive swaps; regular a execução dos serviços de compensação de cheques e outros papéis.

3 "Transação", aqui, não é utilizado no sentido técnico-jurídico.
} 
Essa inflação normativa provocada por órgãos vinculados ao Poder Executivo termina por colocar em xeque o consagrado princípio da separação dos poderes, atribuído a Montesquieu.

Em recente e instigante artigo sobre a "nova separação dos poderes", Bruce Ackerman afirmou: "regulators make law, and we would not want it any other way". Essa afirmação não seria de forma alguma aceita por uma parte significativa da comunidade jurídica brasileira. Entre nós, no debate jurídico-político sobre os poderes da burocracia reguladora, sempre prevaleceu a doutrina que nega ao regulamento toda e qualquer possibilidade de criar restrições à liberdade e à propriedade que já não estejam previamente delineadas em alguma lei. Assim, o regulamento, tido como fonte secundária do direito, não poderia criar obrigações de fazer ou não fazer. Somente a lei, fonte primária do direito, poderia fazê-lo. ${ }^{5}$ A versão mais radical dessa doutrina, de forte caráter liberal, vai ainda mais além e chega a sustentar que os atos normativos emanados dos órgãos reguladores têm, na nova ordem constitucional brasileira, um caráter meramente infra-regulamentar, já que o regulamento propriamente dito só poderia ser editado pelo Presidente da República e pelos Ministros de Estado. ${ }^{6}$

A doutrina predominante no direito público brasileiro distingue a função normativa primária, que inova a ordem jurídica, da função normativa secundária, que não realiza essa inovação. Atualmente, no Brasil, o Poder Executivo exerce aquela primeira função através das medidas provisórias (decorrente de atribuição constitucional) e de leis delegadas (decorrente de delegação legislativa). Edita ele também atos normativos secundários, por atribuição constitucional, que não inovam a ordem jurídica: os regulamentos ${ }^{7}$.

\footnotetext{
${ }^{4}$ Bruce Ackerman, "The new separation of powers", Harvard Law Review 113 (2000), p. 695.

${ }^{5}$ Cf. Celso Antônio Bandeira de Mello, Curso de Direito Administrativo, $12^{\mathrm{a}}$ ed. rev., atual. e ampl., São Paulo: Malheiros, 2000, pp. 296-303.

${ }^{6}$ Geraldo Ataliba, "Delegação normativa (limites às competências do CMN e do Bacen)", Revista de Direito Público 98 (1991), p. 59.

${ }^{7}$ Cf. Clèmerson Merlin Clève, Atividade Legislativa do Poder Executivo no Estado Contemporâneo e na Constituição de 1988, São Paulo: RT, 1993, p. 131; e Carlos Mário da Silva Velloso, "Delegação Legislativa - a Legislação por Associações”, in Temas de Direito Público, Belo Horizonte: Del Rey, 1997, pp. 40-438. Do mesmo autor, "Do poder regulamentar", ibid., pp. 439-456.
} 
Entende-se, também, que a atual constituição brasileira consagrou o princípio da indelegabilidade legislativa, ainda que não haja, em seu texto, disposição literal neste sentido $^{8}$.

Considerado um corolário do princípio da separação dos poderes, o princípio da indelegabilidade legislativa tem três premissas fundamentais. ${ }^{9}$ A primeira delas é a máxima delegata potestas delegari non potest - a atribuição constitucional de competências (legislativa, executiva ou jurisdicional) seria o resultado de uma delegação do legislador constituinte. Assim, o órgão estatal não poderia criar uma nova delegação e repassar sua competência a outro órgão. A segunda premissa é o princípio da representação política. O órgão legislativo, representante eleito do povo, teria o poder-dever de exercer a função legislativa. A terceira premissa é o princípio da supremacia da constituição - a decisão de distribuição de competências pelo constituinte não pode ser desrespeitada pela decisão do legislador ordinário, o que fundamenta o controle de constitucionalidade, especialmente a possibilidade de o Judiciário anular as delegações legislativas.

A regra da indelegabilidade legislativa, juntamente com a concepção estrita do poder regulamentar, faz com que o caráter inovador das normas editadas pela burocracia reguladora não seja aceito por parte importante dos doutrinadores: ou se lhes reconhece a validade, quando se considera que elas não inovam o ordenamento, ou são elas consideradas ilegais ou inconstitucionais, quando têm a pretensão de inovar.

Os doutrinadores do Direito Público brasileiro têm apresentado duas reações básicas ao agigantamento dos poderes da burocracia econômica. A primeira delas, caudatária do pensamento jurídico liberal descrito supra, consiste em sustentar uma interpretação rígida do princípio da separação dos poderes, o que implica a inconstitucionalidade das normas editadas pela burocracia. A segunda, que poderia ser chamada de vanguardista, tenta reformular categorias e esquemas interpretativos, assumindo a premissa - realista - de que a complexidade técnica das atribuições da burocracia exige que lhe seja conferido um poder normativo de conjuntura.

\footnotetext{
${ }^{8}$ Geraldo Ataliba, "Delegação Normativa (Limites às Competências do CMN e do BACEN)", in Revista de Direito Público 98 (1991), pp. 50-69.

${ }^{9}$ Sigo, aqui, a exposição de Carlos Roberto de Siqueira Castro, O Congresso e as Delegações Legislativas, Rio de Janeiro: Forense, 1986, pp. 40 e ss. Mas excluí a última premissa desenvolvida pelo autor: a cláusula do devido processo legal, doutrina de controle da legalidade do poder regulamentar de polícia do Estado, desenvolvida nos EUA.
} 
Aquela primeira corrente doutrinária pode ser sintetizada da seguinte forma: ${ }^{10}$

(1) Num Estado Democrático de Direito (que consagra o princípio liberal e o princípio democrático), há o governo das leis, e não o governo dos homens;

(2) Fundamental, para tanto, é o princípio da legalidade; ${ }^{11}$

(3) Segundo o princípio constitucional da legalidade, ninguém deverá fazer ou deixar de fazer algo senão em virtude de lei;

(4) Lei é o resultado do processo legislativo, ou seja, é produzida pelo Parlamento (= órgão legislativo) (lei em sentido formal - daí a tautologia da definição);

(5) Somente a lei é fonte primária, ou seja, só ela pode inovar a ordem jurídica, criando obrigações de fazer e não fazer (= lei em sentido material: preceito genérico e abstrato que impõe restrições - novas - à liberdade e à propriedade);

(6) A delegação legislativa só não é inconstitucional quando estiver explícita no texto da Constituição;

(7) Esse princípio impede a edição de preceitos de caráter legislativo (lei em sentido material) sob o rótulo de regulamento;

(8) Os únicos regulamentos permitidos pela Constituição seriam os de execução, ou seja, aqueles que visam à fiel execução da lei, sem a criação de novos direitos ou obrigações;

(9) Foi justamente para evitar a usurpação da função legislativa que a Constituição de 1988, instaurando um regime liberal-democrático, estabeleceu, no artigo 25 do Ato das Disposições Constitucionais Transitórias, a revogação de "todos os dispositivos legais que atribuam ou deleguem a órgão do Poder Executivo

${ }^{10}$ Cf. Celso Antônio Bandeira de Mello, "Regulamento e Princípio da Legalidade", Revista de Direito Público 96 (1990), e Curso de Direito Administrativo, ob. cit., pp. 294 e ss.; Geraldo Ataliba, "Poder Regulamentar do Executivo", Revista de Direito Público 57-58 (1981), pp. 184-208, e "Delegação Normativa (Limites às Competências do CMN e do BACEN)", Revista de Direito Público 98 (1991), pp. 5069. Cf. também Luís Roberto Barroso, "Disposições Constitucionais Transitórias (natureza, eficácia e espécie), Delegações Legislativas (validade e extensão), Poder Regulamentar (conteúdo e limites)", Revista de Direito Público 23 (1990), pp. 69-80, e "Apontamentos sobre o princípio da legalidade", in Temas de direito consittucional, Rio de Janeiro: Renovar, 2001, pp. 165-188; Clèmerson Merlin Clève, Atividade legislativa do Poder Executivo no Estado contemporâneo e na Constituição de 1988, São Paulo: RT, 1993, p. 131. Um comentário relativamente recente sobre as agências reguladoras é taxativo: o poder normativo de todas elas é inconstitucional, exceto o da ANEEL e da ANATEL, previstas na Constituição (Ives Gandra Martins, “A Constituição e as agências regulatórias", Valor Econômico, 31.05.2001, p. B-2).

${ }^{11}$ Constituição Federal de 1988 , art $5^{\circ}$ :

“Art. $5^{\circ}$ Todos são iguais perante a lei, sem distinção de qualquer natureza, garantindo-se aos brasileiros e aos estrangeiros residentes no País a inviolabilidade do direito à vida, à liberdade, à igualdade, à segurança e à propriedade, nos termos seguintes:

“[...] II - ninguém será obrigado a fazer ou deixar de fazer alguma coisa senão em virtude de lei;" 
competência assinalada pela Constituição ao Congresso Nacional”, inclusive no que se refere a "ação normativa";

(10)As resoluções do $\mathrm{CMN}$, publicadas pelo $\mathrm{BCB}$, em sua grande parte, extrapolam esse limite, configurando um escandaloso exercício de poder legislativo.

Segundo essa concepção, regulamento é "ato administrativo normativo veiculado por decreto expedido no exercício de função regulamentar, contendo as disposições dirigidas aos subordinados do editor, regulando (disciplinando) o modo de aplicação das leis administrativas, cuja execução lhe incumbe". ${ }^{12}$

Constrói-se, assim, a interpretação segundo a qual o princípio da separação dos poderes - uma das "cláusulas pétreas"13 - teria, no direito brasileiro, mais rigidez do que em outros países democráticos. Tal posição resultaria do próprio texto da Constituição, que só admitiria a edição de regulamentos para a "fiel execução da lei"

A Constituição estabelece que é competência privativa da União legislar sobre o sistema monetário, a política de crédito, câmbio, seguros e transferência de valores ${ }^{15}$, sendo que as operações de crédito do setor público só podem ser objeto de resolução do Senado Federal. ${ }^{16}$ Para o CMN e o BCB restaria tão somente a função de fiscalizar o cumprimento das leis editadas pelo Senado e pelo Congresso.

${ }^{12}$ Geraldo Ataliba, "Poder regulamentar do Executivo", ob. cit., p. 187.

${ }^{13} \mathrm{CF}$ art. 60 , parágrafo $4^{\circ}$, III: proíbe que seja objeto de deliberação a proposta de emenda constitucional tendente a abolir a separação dos poderes.

14 “Art. 84 Compete privativamente ao Presidente da República:

"[...] IV - sancionar, promulgar e fazer publicar as leis, bem como expedir decretos e regulamentos para a sua fiel execução;"

${ }^{15}$ Art. 22, VI e VII.

16 “Art. 52 Compete privativamente ao Senado Federal:

"[...] V - Autorizar operações externas de natureza financeira, de interesse da União, dos Estados, do Distrito Federal, dos Territórios e dos Municípios;

"VI - fixar, por proposta do Presidente da República, limites globais para o montante da dívida consolidada da União, dos Estados, do Distrito Federal e dos Municípios;

"VII - dispor sobre os limites globais e condições para as operações de crédito externo e interno da União, dos Estados, do Distrito Federal e dos Municípios, de suas autarquias e demais entidades controladas pelo Poder Público federal;

"VIII - dispor sobre os limites e condições para a concessão de garantia da União em operações de crédito externo;

"IX - estabelecer limites globais e condições para o montante da dívida mobiliária dos Estados, do Distrito Federal e dos Municípios". 
Implícito na nova ordem constitucional estaria, portanto, o princípio da vedação da delegação legislativa. Todas as constituições republicanas anteriores, com exceção da Carta de 1937, continham expressamente a norma que vedava a qualquer um dos Poderes delegar funções a outro. Esse texto normativo não se repetiu na Constituição de 1988, mas essa corrente doutrinária entende que o princípio da vedação decorreria logicamente do princípio da separação dos poderes. Uma evidência de que a Constituição não admite o poder normativo das autoridades monetárias brasileiras nem de quaisquer outros órgãos administrativos estaria no já referido art. 25 do Ato das Disposições Constitucionais Transitórias (ADCT):

“Art. 25 Ficam revogados, a partir de cento e oitenta dias da promulgação da Constituição ${ }^{17}$, sujeito este prazo a prorrogação por lei, todos os dispositivos legais que atribuam ou deleguem a órgão do Poder Executivo competência assinalada pela Constituição ao Congresso Nacional, especialmente no que tange a:

"I - ação normativa"

O texto constitucional parece ser claro: trata-se de uma revogação explícita das leis que davam competências normativas ao $\mathrm{CMN}$ e ao $\mathrm{BCB}$, dentre outros órgãos da Administração Pública. A lei (=lei em sentido formal) que seria necessária para prorrogar a vigência dessas competências só foi promulgada em junho de $1990^{18}$, portanto, depois do prazo de cento e oitenta dias. ${ }^{19}$

Do ponto de vista técnico-jurídico, não teria ocorrido a prorrogação. Já que não se pode prorrogar a vigência de leis já revogadas, a lei editada em junho de 1990 estaria na verdade criando nova delegação legislativa, o que seria inconstitucional na nova ordem, que veda a delegação.

Entretanto, a questão complica-se com a constatação de que dentro do prazo de cento e oitenta dias foi editada uma medida provisória ${ }^{20}$ que pretendia realizar a necessária prorrogação. Esta medida provisória só foi aprovada pelo Congresso após o decurso daquele prazo de cento e oitenta dias. Considerando-se que a exigência do art. 25 do

\footnotetext{
${ }^{17}$ Como é sabido, a Constituição foi promulgada em 5 de outubro de 1988.

${ }^{18}$ Lei 8056, de 28 de junho de 1990.

${ }^{19}$ O prazo expirou na primeira semana de abril de 1990, seis meses após a promulgação.

${ }^{20}$ Medida Provisória 45, de 31 de março de 1989.
} 
ADCT era de lei em sentido formal, ainda que se aceitasse que a prorrogação pudesse ser feita por medida provisória convertida em lei - algo bastante questionável -, a prorrogação não teria sido efetuada, pois a medida provisória não foi convertida em lei tempestivamente.

Uma segunda reação da doutrina do direito público brasileiro ao agigantamento dos poderes normativos da burocracia estatal caminha num sentido inverso. Do ponto de vista dogmático, essa reação não é homogênea. Ela é desenvolvida por autores isolados que seguem caminhos distintos. Não chega, portanto, a construir uma nova interpretação dominante sobre a capacidade normativa de conjuntura. Apesar dessas diferenças, seu traço comum é o rompimento com o discurso jurídico-político tradicional da separação dos poderes - sempre calcado na leitura convencional de Montesquieu e na versão da doutrina da separação dos poderes que a ele se costuma atribuir. Essas construções dogmáticas são aqui designadas de vanguardistas, no sentido de que introduzem uma mudança fundamental na concepção predominante da doutrina da separação dos poderes.

Dois exemplos serão aqui resumidos. Trata-se de duas construções doutrinárias que se excluem uma à outra, apesar de enfrentarem o mesmo problema: o dogma da vedação da delegação legislativa no direito brasileiro, reforçado pelo art. 25 do ADCT. Não esgotam, obviamente, o rol de interpretações alternativas que vêm sendo desenvolvidas nos últimos dez anos, mas representam argumentações originais e importantes no contexto do debate sobre o poder normativo da burocracia. Mais que isso, elas demonstram os dois caminhos fundamentais que se apresentam para a construção de uma doutrina que, ao mesmo tempo, possa reconhecer e controlar a capacidade normativa de conjuntura: (i) a aceitação da delegação legislativa como decorrente de mutação constitucional ou (ii) a ampliação do poder regulamentar para além do regulamento de mera execução da lei.

A primeira delas, elaborada por Tercio Sampaio Ferraz Junior, ${ }^{21}$ parte da premissa de que o princípio da legalidade teria passado por um processo de mutação constitucional, o que exigiria o entendimento da legalidade numa dupla perspectiva: (i) legalidade

${ }^{21}$ Passo a resumir, aqui, a argumentação do autor, desenvolvida em Tercio Sampaio Ferraz Jr., "Agências reguladoras: legalidade e constitucionalidade", Revista Tributária e de Finanças Públicas 35 (2000), pp. $143-158$. 
condicional (de bloqueio); (ii) legalidade legitimadora (de legitimação de objetivos). ${ }^{22}$ Sob inspiração da cibernética, a distinção entre lei como estrutura condicional e a lei como estrutura finalística seria uma forma de pensar a validade normativa incorporando a relação meio/fim. Assim, considera-se que "uma norma valida outra, condicionalmente, se preestabelece condições que devem ser respeitadas e nestas condições localiza a validade da norma subseqüente, independentemente se os fins normativos são ou não atingidos". ${ }^{23}$ Já a validação finalística exige a solidariedade entre fins preestabelecidos vinculantes e meios adequados, daqueles primeiros dependentes. É ao identificar no texto legal essas duas formas de validação que o intérprete pode trazer à luz o novo sentido do princípio da legalidade. $^{24}$

Essa construção permite ao autor desenvolver a legalidade legitimadora não como limite, mas como um instrumento de exercício da atividade administrativa, que deve ser avaliada de acordo com sua eficiência. Isso exige uma compreensão da discricionariedade que extrapole o mero juízo de oportunidade, passando a envolver um juízo de realidade, ou seja, a "avaliação de políticas de implementação de objetivos, de adequação dos meios escolhidos em face dos fins propostos". 25

A introdução formal do princípio da eficiência no art. 37 da Constituição ${ }^{26}$ veio confirmar esse novo sentido da legalidade, trazendo consigo a base para o que o autor denomina de delegação instrumental. ${ }^{27}$ Sendo um princípio fim, que impõe resultados, e não um princípio meio, que impõe limites, a eficiência permite ler de forma mais ampla o art. 174 da Constituição ${ }^{28}$, que se refere ao Estado enquanto agente normativo e regulador da atividade econômica, reforçando a tese de que é válida a delegação de poder às agências sem que se viole o princípio da irrenunciabilidade do poder-dever de legislar, contido no art. 25 do ADCT. $^{29}$ Diante da complexidade das matérias e relações a serem reguladas, a

\footnotetext{
${ }^{22}$ Ibid., pp. 152 ss.

${ }^{23}$ Ibid., p. 153.

${ }^{24}$ Ibid., p. 153.

${ }^{25}$ Ibid., p. 154.

26 “Art. 37 A administração pública direta e indireta de qualquer dos Podres da União, dos Estados, do Distrito Federal e dos Municípios obedecerá aos princípios de legalidade, impessoalidade, moralidade, publicidade e eficiência e, também, ao seguinte: [...]"

${ }^{27}$ Ibid., p. 150.

28 “Art. 174 Como agente normativo e regulador da atividade econômica, o Estado exercerá, na forma da lei, as funções de fiscalização, incentivo e planejamento, sendo este determinante para o setor público e indicativo para o setor privado.[...]"

${ }^{29}$ Ibid., p. 150.
} 
exigir, do Estado regulador, uma crescente especialização técnica, “é impossível exigir-se eficiência da Administração sem dar-lhe competência para alocar fins específicos e encontrar meios correspondentes". ${ }^{30}$ Se o Estado regulador é responsável pela consecução de resultados, pela relação solidária de meios e fins, pelo êxito de sua ação, ele não pode executar sua tarefa sem a delegação instrumental.

A construção que Tercio Sampaio Ferraz Junior desenvolve para o fundamento constitucional da delegação instrumental para órgãos reguladores é acompanhada de uma preocupação com o controle dessa delegação, ou com os limites que a própria eficiência impõe. Ele esclarece que ela não é nem delegação de fiel cumprimento da lei nem lei delegada, mas uma forma de delegação criada no direito brasileiro a partir da introdução do princípio da eficiência no texto constitucional. ${ }^{31} \mathrm{O}$ limite inicial seria o estabelecimento de uma diretriz para uma política setorial pelo Poder Legislativo. A delegação instrumental ocorre para que a Administração escolha os fins tecnicamente viáveis e os meios adequados. Em outras palavras, é o órgão político que toma a decisão política fundamental a serviço da qual se estabelece a delegação instrumental ao órgão regulador. ${ }^{32} \mathrm{O}$ controle judicial do mérito da regulações seria amplo, abrangendo os atos discricionários, já que estes também têm a eficiência como pressuposto. Em outras palavras, mesmo os atos discricionários poderiam ser controlados a partir do critério de sua adequação aos objetivos políticos setoriais determinados em lei. ${ }^{33}$

A segunda construção trazida aqui como exemplo da parcela vanguardista da doutrina brasileira foi desenvolvida por Eros Roberto Grau. ${ }^{34}$ Ela é imbuída do mesmo realismo da construção anterior, reconhecendo a inovação jurídica operada por órgãos como o CMN:

"O exercício da capacidade normativa de conjuntura estaria, desde a visualização superficial dos arautos da 'separação' de poderes, atribuído ao Poder Legislativo, não ao Poder Executivo. A doutrina brasileira tradicional do direito administrativo,

\footnotetext{
${ }^{30}$ Ibid., p. 151.

${ }^{31}$ Ibid., p. 154.

${ }^{32}$ Ibid., p. 154.

${ }^{33}$ Ibid., p. 157.

${ }^{34}$ Passo a expor aqui a construção doutrinária de Eros Roberto Grau, em "Crítica da 'separação dos poderes': as funções estatais, os regulamentos e a legalidade no Direito brasileiro, as leis-medida", in $O$ direito posto $e$ o direito pressuposto, São Paulo: Malheiros, 1996, pp. 167-190.
} 
isolando-se da realidade, olimpicamente ignora que um conjunto de elementos de índole técnica, aliado a motivações de premência e celeridade na conformação do regime a que se subordina a atividade de intermediação financeira, tornam o procedimento legislativo, com seus prazos e debates prolongados, inadequado à ordenação de matérias essencialmente conjunturais. No que tange ao dinamismo do sistema financeiro, desconhece que o caráter instrumental da atuação de seus agentes, e dele próprio, desenha uma porção da realidade à qual não se pode mais amoldar o quanto as teorias jurídicas do século passado explicavam. Por isso não estão habilitados, os seus adeptos, a compreender o particular regime de direito a que se submete o segmento da atividade econômica envolvido com a intermediação financeira. Não é estranho, assim, que essa doutrina - no mundo irreal em que se afaga - não avance um milímetro além da afirmação, por exemplo, de que todas as resoluções do Conselho Monetário Nacional, editadas pelo Banco Central do Brasil, são inconstitucionais!"35

Ao contrário de Tercio Sampaio Ferraz, porém, Eros Grau rejeita a solução formal da delegação legislativa. Prefere, antes, ampliar o conceito de poder regulamentar. O caminho adotado para isso é a reformulação do princípio da legalidade, que passa a ser concebido como reserva de lei em termos relativos, ou reserva da norma. ${ }^{36}$

Fundamental para essa proposta é o conceito de norma jurídica, que é definida como um preceito abstrato, genérico e inovador da ordem jurídica, impondo-se por força própria, autônoma. ${ }^{37}$ Esta primariedade da norma não se confunde com a originariedade, $\mathrm{o}$ significa que não deixa de ser primário um preceito que integra um ordenamento derivado ou um preceito que seja emanado com fundamento em uma atribuição de poder normativo conferida a órgão que ordinariamente não o detenha. ${ }^{38}$

Em contraposição a uma classificação orgânica ou institucional das funções estatais, que abrange a função legislativa, a executiva e a jurisdicional, o autor adota uma classificação material:

(1) função normativa - e não legislativa: produção de normas jurídicas;

\footnotetext{
${ }^{35}$ Ibid. p. 173.

${ }^{36}$ Ibid., p. 184.

${ }^{37}$ Ibid., p. 178.

${ }^{38}$ Ibid., p. 178.
} 
(2) função administrativa: execução de normas jurídicas;

(3) função jurisdicional: aplicação das normas jurídicas.

Segundo essa concepção, o autor, seguindo Renato Alessi, toma lei e norma como noções distintas:

“[Lei é] toda estatuição, embora carente de conteúdo normativo, expressa, necessariamente com valor de estatuição primária, pelos órgãos legislativos ou por outros órgãos delegados daqueles.

“A lei não contém, necessariamente, uma norma. Por outro lado, a norma não é necessariamente emanada mediante uma lei. E, assim, temos três combinações possíveis: a lei-norma, a lei não-norma, e a norma não-lei. ${ }^{\text {39 }}$

A lei é tomada, aqui, como lei em sentido formal. Essa linha de argumentação pretende refutar a afirmação - já corriqueira - segundo a qual o Poder Executivo tem exercido função legislativa, com a derrogação do princípio da separação dos poderes.

Fundamental para tanto é conceber o regulamento como uma estatuição primária, mesmo que não emanado de poder originário. Os regulamentos são preceitos derivados porque se fundam sobre uma atribuição de poder normativo contida explícita ou implicitamente na Constituição ou em uma lei (= lei em sentido formal). O exercício da função regulamentar pelo Executivo não decorre, portanto, de uma delegação de função legislativa, nem do poder discricionário da Administração. Seu fundamento é a atribuição de potestade normativa material.

A função estatal normativa é gênero do qual a função legislativa, que tem como titular o Poder Legislativo, é espécie, pois o Executivo e o Judiciário também exercem espécies de função normativa: funções regulamentar e regimental. ${ }^{40}$

A distinção entre lei e norma confere ao principio da legalidade ${ }^{41}$ uma dupla dimensão. Não há somente a reserva da lei, mas também a reserva da norma (que pode ser legal, regulamentar ou regimental).

${ }^{39}$ Ibid., p. 179. A obra de Alessi citada é o Principii di diritto amministrativo, $4^{\mathrm{a}}$. ed., v. I, Milano: Giuffrè, 1978, pp. 5-7 e 14.

${ }^{40}$ Ibid., pp. 180-181. 
A legalidade absoluta é historicamente consagrada em relação à liberdade do indivíduo (a), à limitação ao poder de tributar do Estado (b), e à liberdade de indústria e comércio (c):

(a) Não há crime sem lei anterior que o defina, nem pena sem prévia cominação legal ${ }^{42}$

(b) É vedado ao Estado exigir ou aumentar serviço público sem lei que o estabeleça, ${ }^{43}$

(c) É assegurado a todos o livre exercício de qualquer atividade econômica, independentemente de autorização de órgãos públicos, salvo nos casos previstos em lei. ${ }^{44}$

Em todos esses casos, a Constituição se refere à lei em sentido formal, o que não acontece no texto do art. $5^{\circ}$, II: "ninguém será obrigado a fazer ou deixar de fazer alguma coisa senão em virtude de lei" - trata-se, aqui, de um princípio relativo. Se assim não fosse, por que haveria a necessidade de repeti-lo especificamente em outros artigos da Constituição? O que o art. $5^{\circ}$ estipula é uma reserva da "lei" em sentido amplo, ou mais exatamente, a reserva da norma, o que não impede a atribuição implícita ou explícita ao Executivo para, no exercício de função normativa (regulamentar), inovar a ordem jurídica, criando direitos e deveres inéditos para os indivíduos. Só esta interpretação teleológica permite visualizar a fundamentação da função normativa

“[...] na vocação do ordenamento jurídico a realizar-se como um todo, para o que é indispensável a atuação da função normativa em sua globalidade, isto é, das funções legislativa, regulamentar e regimental, e não apenas da primeira delas." ${ }^{\text {"45 }}$

Nessa linha de argumentação, é possível sustentar a existência de três tipos de regulamento no direito positivo brasileiro:

${ }^{41} \mathrm{CF}$ art. $5^{\circ}$, II, referido supra, nota $\mathrm{n}^{\mathrm{o}} 18$.

${ }^{42} \mathrm{CF}$ art. $5^{\circ}$, XXXIX.

${ }^{43} \mathrm{CF}$ art. 150, I.

${ }^{44} \mathrm{CF}$ art. 170 , parágrafo único.

${ }^{45}$ Ibid., p. 186. 
(1) regulamentos de execução: visam à fiel execução da lei;

(2) regulamentos autorizados - e não "delegados", como quer a doutrina tradicional: não decorrem de delegação, mas sim de simples autorização explícita que o Legislativo concede para o exercício de função regulamentar da qual o Executivo já é titular;

(3) regulamentos autônomos: decorrem de atribuição implícita - se a Constituição estabelece fins, os meios são presumidos. ${ }^{46}$

O poder regulamentar do $\mathrm{CMN}$ e do $\mathrm{BCB}$ seria principalmente da segunda espécie. O seu reconhecimento é um primeiro passo para o seu controle. A postura da doutrina tradicional, que simplesmente ignora o poder regulamentar da burocracia econômica, por considerá-lo inconstitucional, bloqueia o debate sobre o seu controle democrático.

Como se viu, as duas construções doutrinárias aqui resumidas exemplificam a busca de caminhos alternativos para fundamentação e o controle da capacidade normativa de conjuntura. ${ }^{47}$ A primeira, pela delegação legislativa instrumental, a segunda, pela

\footnotetext{
${ }^{46} \mathrm{O}$ autor toma o exemplo do art. 21, XII, da Constituição, que permite à União conceder serviços públicos. Embora não haja atribuição explícita de poder regulamentar, ele é indispensável para que se criem regras sobre a exploração desses serviços. Ibid., p. 188.

${ }^{47}$ Há vários trabalhos que sustentam a constitucionalidade do poder normativo dos órgãos reguladores e uma releitura da separação dos poderes, mas a doutrina predominante, como já referido, é no sentido contrário. Como exemplos de construções doutrinárias vanguardistas, ver Carlos Ari Sundfeld, "Serviços públicos e regulação estatal: introdução às agências reguladoras", in Carlos Ari Sundfeld (coord.), Direito Administrativo Econômico, São Paulo: Malheiros, 2000, pp. 17-38; Diogo de Figueiredo Moreira Neto, "Agências reguladoras (descentralização e deslegalização)", in Mutações do Direito Administrativo, 2a . ed., Rio de Janeiro: Renovar, 2001, pp. 149-184; Simone Lahorgue Nunes, Os fundamentos e os limites do poder regulamentar no âmbito do mercado financeiro, Rio de Janeiro: Renovar, 2000; Alexandre Aragão, "As agências reguladoras independentes e a separação de poderes - uma contribuição da teoria dos ordenamentos setoriais”, Revista dos Tribunais 786 (2001), pp. 11-56; Sérgio Varella Bruna, Agências reguladoras: poder normativo, consulta pública, revisão judicial, São Paulo: RT, 2003. Anteriormente à Constituição de 1988, destaca-se o trabalho de Sérgio Ferraz, "Regulamento", in 3 estudos de direito, São Paulo: RT, 1977, pp. 105-126 (contrário à tese da delegação legislativa, sustentando a existência do regulamento autônomo, ainda que decorrente do costume constitucional, por ser o poder regulamentar inerente à Administração, a quem a Constituição conferiria, ainda que implicitamente, as potestades necessárias para o cumprimento de um dever que ela própria, Constituição, impôs ao Poder Executivo). Ver também L. G. Paes de Barros Leães, Mercado de Capitais \& Insider Trading, São Paulo: RT, 1982: o autor sustenta que a Constituição de 1969 (art. 81,V: competência do Presidente da República para "dispor sobre a estruturação, atribuições e funcionamento dos órgãos da administração") consagrava os regulamentos de organização, que seriam regulamentos independentes. Resenha a construção jurisprudencial norte-americana dos poderes coeficientes que, reformando a non-delegation doctrine, permitiu nos Estados Unidos a edição do que a tradição continental denomina de regulamentos autorizados (para os americanos, é muito mais "delegado" do que autorizado). Apesar de reconhecer a inadequação desta doutrina para o Brasil, sustenta que o fato de nossas instituições do mercado de capitais serem plasmadas à imagem e semelhança das americanas implica a necessidade da adoção, entre nós, dos regulamentos autorizados. Aliás, do começo ao fim a argumentação do autor baseia-se na necessidade prática e na efetividade, como bem ilustra o trecho seguinte, extraído da pág. 27: "A legislação dos mercados financeiros e de capitais obedeceu a processo pouco habitual em nossa técnica
} 
ampliação do poder regulamentar - inclusive pelo reconhecimento da existência do regulamento autônomo no direito brasileiro.

Esse debate exclui, obviamente, a possibilidade de delegação legislativa decorrente de expressa previsão constitucional (delegação legislativa nominada) - é o caso da lei delegada na atual Constituição brasileira. ${ }^{48} \mathrm{O}$ problema está na validade de delegações efetuadas pela legislação infraconstitucional (delegação inominada). ${ }^{49}$

Pode-se questionar se as delegações inominadas ou não formais podem ser consideradas fórmulas ampliativas do poder regulamentar do Executivo. Neste ponto, há divergências na doutrina. Alguns autores não aceitam a delegação como fundamento do poder regulamentar. Este seria atribuído ao Executivo diretamente pela Constituição, ainda que de forma implícita ${ }^{50}$, ou seria decorrência do poder discricionário da Administração ${ }^{51}$.

O entendimento da delegação legislativa é fundamental para a concretização do princípio da legalidade em sua dupla dimensão: legalidade como preeminência da lei e legalidade como reserva da lei. A primeira, relacionada à hierarquia das normas, a segunda, à distribuição de competências. A reserva de lei pode ser material (admissão de regulação por atos materialmente legislativos) e formal, absoluta e relativa (admissão da atuação subjetiva integradora do aplicador da norma). No Brasil, de modo geral, o princípio da legalidade é entendido como reserva de lei quanto à criação de deveres e

legislativa, o que por certo explica a atitude de suspicácia a vários de seus mais interessantes expedientes. A sua plasticidade custou a encontrar eco (se é que já encontrou plenamente) em nossos pretórios, que brandiam conceitos venerandos tais como a preservação da organização constitucional, a manutenção do princípio da separação dos poderes e a supremacia da lei no Estado de Direito. Espíritos mais sensíveis chegaram até a falar em 'tirania do Executivo'. Devemos convir que as reações aqui lembradas são de pouco prestadio, ante a eficácia total desse corpo de normas específicas a disciplinar segmento importante da economia nacional há mais de dois lustros. Mas devem ser lembradas quando se pensa, como ora o fazemos, em estudar o seu espírito e a sua estrutura normativa" (grifei) - eficácia, aqui, foi obviamente usada no sentido sociológico de efetividade. Também para o período anterior à atual Constituição, ver Carlos Roberto Siqueira Castro, O Congresso e as delegações legislativas, ob.cit.

${ }^{48}$ CF 1988, art. 68.

49 Segundo uma outra classificação, as delegações podem ser formais e não formais, o que termina equivalendo àquela primeira dicotomia (Clèmerson Merlin Clève, A atividade legislativa do Poder Executivo, ob. cit. p. 127).

${ }^{50}$ Eros Roberto Grau, “Crítica da 'separação dos poderes': as funções estatais, os regulamentos e a legalidade no Direito brasileiro, as leis-medida", in O Direito Posto e o Direito Pressuposto, São Paulo: Malheiros, 1996, pp. 167 a 199, e Carlos Medeiros Silva, “O Poder Regulamentar e sua Extensão”, Revista Forense 130 (1950), p. 339.

${ }^{51}$ Clenício da Silva Duarte, “Os Regulamentos Independentes”, Revista de Direito Público 16 (1951), p. 94. 
obrigações, e como preeminência de lei nos demais domínios das relações públicas e privadas. $^{52}$

Por outro lado, a discussão sobre os fundamentos do poder regulamentar é o complemento necessário para aquele processo de concretização, particularmente no que se refere ao poder normativo, ou capacidade normativa de conjuntura, de órgãos como o Conselho Monetário Nacional, o Banco Central, e as polêmicas agências reguladoras.

A relação entre lei e regulamento, entre delegação legislativa e ampliação do poder regulamentar tem sido o eixo da discussão dogmática sobre a distribuição de competências normativas no Direito Público brasileiro. Aquela relação é considerada ora de complementação, ora de exclusão recíproca. ${ }^{53}$

Já se sugeriu também a busca do sentido constitucional da indelegabilidade legislativa - flexibilizando-a, mediante a "importação" das doutrinas americanas do filling up details e da delegation with standards, que propõem, respectivamente, a admissão de delegação como regulamentação de normas gerais editadas pelo Legislativo, e a delegação explícita com limites dados pelo poder delegante. ${ }^{54}$ É o que defende Carlos Roberto de Siqueira Castro, que aponta oito requisitos e características da delegação legislativa ${ }^{55}$ :

(1) previsão na Constituição ou em lei formal;

(2) ato expresso de delegação da competência normativa;

(3) transferência da função legislativa originária do Poder Legislativo a comissão especial do Congresso ou a órgão ou agente de outro poder do Estado;

(4) limitações fixadas pelo Poder delegante;

(5) possibilidade de revogação e indelegabilidade da delegação;

(6) preservação de idêntica competência delegada pelo Poder delegante;

(7) controle político do órgão delegante sobre a legislação delegada;

52 Cf. Luís Roberto Barroso, "Disposições Constitucionais Transitórias (natureza, eficácia e espécie), Delegações Legislativas (validade e extensão), Poder Regulamentar (conteúdo e limites)", ob. cit., e "Apontamentos sobre o princípio da legalidade", ob. cit.

${ }^{53}$ Cf. Carlos Roberto de Siqueira Castro, O Congresso e as Delegações Legislativas: limites do poder normativo do Executivo, Rio de Janeiro: Forense, 1986.

54 Também não é objetivo do texto desenvolver essas duas doutrinas "importadas", mas simplesmente registrar sua existência.

${ }^{55}$ Ibid., p. 95 (grifos meus). 
(8) controle jurisdicional sobre a observância pela autoridade delegada das condições e limites estabelecidos pelo Poder Legislativo no ato da delegação.

No entanto, esta última posição tem sido minoritária na doutrina. A indelegabilidade continua sendo entendida de forma absoluta, como sempre quis a doutrina brasileira de forte tendência liberal. Sérios problemas são criados para a ordem democrática e para o próprio prestígio da dogmática constitucional, pois não faltam exemplos, na história das instituições brasileiras, da extensão do poder regulamentar, ou da delegação legislativa ${ }^{56}$ :

1859 - O Regulamento 737, de 25 de novembro, que funcionou como a lei processual brasileira por mais de meio século;

1922 - Decreto 15.783, de 8 de novembro: o Código de Contabilidade da União (com 926 artigos);

1933 - Criação do Departamento Nacional do Café;

1933 - Criação do Instituto do Açúcar e do Álcool (IAA);

1939 - O Decreto 4.857, de 9 de novembro, que tratou dos registros públicos;

1945 - Criação da Superintendência da Moeda e do Crédito (SUMOC);

1947 - a Lei 154, de 25 de novembro, alterou o imposto de renda, e convocou, em seu art. 27, o Poder Executivo a regulamentá-la, o que foi feito pelo Decreto 24.239, de 22 de dezembro do mesmo ano (com 206 artigos);

1952 - Criação do Instituto Brasileiro do Café (IBC);

1953 - Criação do Conselho Nacional do Petróleo;

1956 - o Decreto 38.744, de $1^{\circ}$ de fevereiro, criou o Conselho de Desenvolvimento, com poderes que utilizou para elaborar o Plano de Metas;

1957 - Criação do Conselho de Política Aduaneira;

1967 - Criação da Superintendência e Conselho Nacional da Borracha;

1962 - Criação do Conselho Nacional de Telecomunicações;

${ }^{56}$ Cf. Carlos Medeiros Silva, "O Poder Regulamentar e sua Extensão”, ob. cit., p. 339; Carlos Roberto de Siqueira Castro, $O$ Congresso e as Delegações Legislativas, ob. cit., p. 97; e Alberto Venâncio Filho, A intervenção do Estado no domínio econômico, Rio de Janeiro: FGV, 1968. 
1964 - Criação do Conselho Monetário Nacional e do Banco Central;

1964 - Criação do Banco Nacional de Habitação (BNH);

1966 - Criação do Conselho Nacional de Turismo;

1966 - Criação do Conselho Nacional de Seguros Privados.

Essa doutrina liberal, predominante na cultura jurídica brasileira, é desafiada a todo momento pela profusão de normas jurídicas sem as quais o mercado se desestruturaria e o Estado não teria como intervir no domínio econômico também para perseguir outras finalidades que não a mera preservação do sistema econômico.

Um exemplo recente pode ilustrar o que foi dito. Quando, em julho de 2003, o governo do Presidente Luís Inácio Lula da Silva anunciou ao País um programa de microfinanças e de microcrédito, o Conselho Monetário Nacional (CMN) limitou a 2\% ao mês as taxas de juros a serem cobradas pelos bancos comerciais, no âmbito do programa criado, que visava a beneficiar a população de baixa renda e os microempreendedores. ${ }^{57}$ Em outras palavras, o CMN, e não o Congresso Nacional, "legislou", tabelando os juros relativos a certos tipos de operação bancária.

Levada a suas últimas conseqüências, aquela doutrina jurídica inviabilizaria um importante programa de democratização do acesso ao crédito, num país já famoso pelas maiores taxas de juros do mundo.

Entretanto, não é necessário buscar exemplos de inovação da ordem jurídica em ocasiões excepcionais como essa. O exercício dessa capacidade normativa de conjuntura ${ }^{58}$ que inova a ordem jurídica, não ocorre somente em intervenções estatais de caráter "social" ou extraordinário, conforme a hegemonia política ou a crise do momento. Ele é constante. Por mais paradoxal que pareça, é uma atuação conjuntural de caráter

\footnotetext{
${ }^{57}$ Resolução 3.109 , de 24 de julho de 2003, art. $1^{\circ}$, II.

${ }^{58}$ Cf. Eros Roberto Grau, "Capacidade Normativa de Conjuntura", in: Enciclopédia Saraiva de Direito, v. 13, São Paulo: Saraiva, 1977, pp. 48-50: "Desenvolve-se assim, mediante a edição de normas emanadas do Poder Executivo, seja da administração centralizada, seja de alguns de seus entes autônomos, uma dinâmica capacidade normativa, com o que se confere resposta à exigência de produção imediata de normas jurídicas, que as flutuações da conjuntura econômica estão, a todo o tempo, a impor. A essa potestade, em função da qual tais normas são geradas dentro de um clima de dinamismo e flexibilidade adequados à realidade, é que denominamos capacidade normativa de conjuntura" (grifos meus). Ver, também, do mesmo autor, "Crítica da 'separação dos poderes': as funções estatais, os regulamentos e a legalidade no Direito brasileiro, as leismedida", in: O Direito Posto e o Direito Pressuposto, ob. cit., pp. 167 a 199 (especialmente as pp. 172-173).
} 
estrutural. Em outras palavras, trata-se de uma forma de atuação reguladora do Estado indispensável para a preservação da estrutura do mercado financeiro, independentemente do grupo político-partidário que exerce a hegemonia no aparato estatal. $\mathrm{O}$ dia-a-dia dos bancos, seu próprio modo ordinário de funcionar, é condicionado, em cada detalhe, por uma enorme quantidade de normas produzidas pelo órgão regulador do sistema financeiro. As mais conhecidas dizem respeito a atuações da autoridade monetária que constam de qualquer manual de economia.

Tome-se o exemplo do depósito compulsório. Dos três instrumentos clássicos de política monetária, é o que possui claramente uma estrutura jurídica de caráter normativo. Difícil seria imaginar a execução da política monetária sem essa forma jurídica, sem essa flexibilidade, sem essa possibilidade de inovar a ordem jurídica, de restringir a liberdade econômica, a qualquer momento, rapidamente.

No mês seguinte ao anúncio do programa de microcrédito, o BCB reduziu de $60 \%$ para 45\% a alíquota dos recolhimentos compulsórios sobre os depósitos à vista dos bancos. O fundamento legal dessa atuação é encontrado na Lei 4595/64:

“Art. 10. Compete privativamente ao Banco Central do Brasil:

“[...] III - determinar o recolhimento de até $100 \%$ (cem por cento) do total dos depósitos à vista e de até $60 \%$ (sessenta por cento) de outros títulos contábeis das instituições financeiras [...]"

O texto da Circular 3.199, de 08 de agosto de 2003, que permitiu a redução, confirma sua natureza normativa, ou seja, geral e abstrata. Alterando os arts. $4^{\circ}$ e $5^{\circ}$ da Circular 3.169, de 19 de dezembro de 2002, ela determinou quais passariam a ser a base de cálculo e a alíquota para o cálculo do recolhimento compulsório:

"Art. $4^{\circ} \mathrm{A}$ base de cálculo da exigibilidade do recolhimento compulsório e do encaixe obrigatório sobre recursos à vista corresponde à média aritmética dos VSRs apurados no período de cálculo, deduzida de $\mathrm{R} \$ 44.000 .000,00$ (quarenta e quatro milhões de reais). ${ }^{59}$

“Art. 5 A exigibilidade de recolhimento compulsório e de encaixe obrigatório

59 "VSR": "valor sujeito a recolhimento". 
sobre recursos à vista é apurada aplicando-se a alíquota de $45 \%$ (quarenta e cinco por cento) sobre a base de cálculo de que trata o art. $4^{\circ}$."

Se um regulamento de uma autoridade qualquer restringisse o direito de propriedade e a liberdade econômica dos fabricantes de geladeiras, impondo-lhes uma cota máxima de produção, provavelmente haveria um consenso na comunidade jurídica acerca do caráter inovador - e inconstitucional - de tal norma. Ela restringiria, claramente, de forma fundamental, direitos dos agentes econômicos. Ora, no âmbito da regulação financeira, essa restrição é a própria regra, é elemento essencial do quadro regulatório. A regulação do depósito compulsório é uma limitação fundamental do negócio dos bancos, da sua capacidade de fazer empréstimos e de multiplicar moeda.

Somente a falta de compreensão desse fenômeno pode justificar a afirmação de que normas como essa não inovam a ordem jurídica, de que elas vinculariam somente a Administração Pública, ou de que elas consubstanciaram meros regulamentos de execução, dedicados a tecnicalidades neutras. Definitivamente, essas e outras normas editadas pelo órgão regulador do mercado financeiro, em todo o mundo, que fazem parte do cotidiano das instituições financeiras, são muito mais do que regulamentos de execução. Simplesmente não poderia ser diferente, sob pena de se abandonar à sua própria lógica autodestruidora o mercado financeiro e, conseqüentemente, todo o sistema econômico.

O depósito compulsório é apenas o exemplo mais difundido de normas de intervenção no domínio econômico por direção, ${ }^{60}$ no âmbito do mercado financeiro. Se tomarmos as normas de competência em vigor no direito brasileiro, veremos que há uma grande quantidade de competências atribuídas ao Conselho Monetário Nacional (CMN) e ao Banco Central do Brasil (BCB), concentrando-se, naquele primeiro, as competências normativas, e, neste último, as competências de execução e de fiscalização.

$\mathrm{O}$ quadro $\mathrm{n}^{\circ} 01$ abaixo apresenta mais alguns exemplos dessas competências. $\mathrm{O}$ critério usado para a classificação é formal, priorizando-se a estrutura de cada norma jurídica. Como se percebe facilmente, do ponto de vista funcional, encontram-se misturados os instrumentos clássicos de política monetária, de controle do crédito, de

${ }^{60}$ Conforme a conhecida classificação de Eros Roberto Grau (A ordem econômica na Constituição de 1988, $7^{\mathrm{a}}$. ed., rev. e atual., São Paulo: Malheiros, 2002, pp. 174-177). 
política cambial, de supervisão e regulação prudenciais, de controle do meio circulante, além de competências que permitem a criação de instrumentos de preservação da estabilidade do mercado financeiro. O critério de classificação é o seguinte: (a) atos normativos (= normas jurídicas, preceitos genéricos e abstratos); (b) atos concretos e específicos de competência discricionária; (c) atos concretos e específicos vinculados.

As poucas competências indicadas no quadro ainda não são suficientes para demonstrar que o texto normativo legal confere ao $\mathrm{CMN}$ e ao $\mathrm{BCB}$ competências para inovar a ordem jurídica. Embora formalmente o desenho criado pela Lei 4.595/64 estabeleça uma divisão de tarefas entre $\mathrm{CMN}$ e $\mathrm{BCB}$, é necessário não se deixar enganar por esse formalismo. Segundo o depoimento de um ex-presidente do BCB,

“[n]a prática, todavia, não é bem assim. As decisões já chegam prontas ao $\mathrm{CMN}$, que se tornou, ao longo do tempo, um conselho que homologa com pompa as decisões tomadas no âmbito da bem menos conhecida Comissão da Moeda e do Crédito (Comoc). $\mathrm{Na}$ Comoc, o BC preside, seus diretores votam, e também três secretários do Ministério da Fazenda (o secretário executivo, o do Tesouro e o de Política Econômica), além do secretário executivo do Planejamento e o presidente da CVM. Batendo chapa, e fazendo as contas, os 'ortodoxos' ganham todas". 61

A atuação de caráter normativo do $\mathrm{BCB}$, portanto, é relevantíssima. Além das resoluções do $\mathrm{CMN}$, que veiculam duas decisões técnicas, ocorre com regularidade uma delegação formal, via resolução, para que o BCB trate de determinadas matérias. ${ }^{62}$

São tantas e tão variadas as normas editadas pela burocracia econômica que se torna difícil resenhá-las. Tome-se o exemplo das regras de contabilidade. Elas não são meras regras técnicas, que detalham obrigações já previamente desenhadas na Lei 4595/64. O que a lei prevê é que o CMN pode criar normas gerais de contabilidade para as instituições financeiras. Embora não seja comum afirmar isso em textos jurídicos, não é difícil perceber que normas contábeis podem significar, em certos casos, normas sobre o próprio direito de propriedade, bem como sobre a liberdade contratual, uma vez que o

${ }^{61}$ Gustavo Franco, “A área econômica”, Veja, 08.01.2003, p. 66.

${ }^{62}$ O que ocorreu, por exemplo, em 1991, quando a Resolução 1.857, de 15.08.1991, autorizou, na época, o $\mathrm{BCB}$ a "fixar percentual e condições para o recolhimento, a título de encaixe obrigatório, sobre recursos captados pelas Caixas Econômicas”. 
patrimônio é, em última instância, a sua própria expressão contábil. Como apontou Max Weber, ${ }^{63}$ a técnica contábil foi fundamental para o desenvolvimento do capitalismo, ao permitir a quantificação da riqueza e, conseqüentemente, o planejamento estratégico da empresa capitalista.

Os exemplos poderiam se multiplicar indefinidamente. Mediante resoluções, circulares, cartas-circulares, comunicados e portarias a burocracia econômica altera a política monetária, expande ou contrai o crédito, interfere nos contratos privados (consórcios, financiamento no âmbito do mercado imobiliário, importação de bens, contratos bancários, cartões de crédito, leasing, factoring), restringe ou estimula a entrada de capital estrangeiro e impõe limites ao endividamento dos Estados e Municípios. ${ }^{64}$ Desde o início de sua atuação, em 1965, O CMN e o BCB já editaram milhares de normas. Os quadros abaixo ilustram a dimensão quantitativa das diferentes funções que o Congresso e a burocracia exercem. No quadro $\mathrm{n}^{\mathrm{o}} 02$, encontramos atos normativos e atos administrativo concretos e específicos do $\mathrm{CMN}$ e do $\mathrm{BCB}$. O quadro $\mathrm{n}^{\circ} 03$ realiza a comparação da produção normativa agregada do Congresso e da burocracia (CMN/BCB).

\footnotetext{
${ }^{63}$ Max Weber, Economy and society: an outline of interpretative sociology, ed. by Guenther Roth and Claus Wittich, vol.1, New York: Bedminster Press, 1968, pp. 96 e 99.

${ }^{64}$ Para um levantamento e uma análise do impacto político das medidas mais importantes relativas às finanças estaduais e municipais, ver Lourdes Sola et. al., "Banco central, autoridade política e governabilidade democrática", in Lourdes Sola/Eduardo Kugelmas/Laurence Whitehead (orgs.), Banco central: autoridade política e democratização - um equilíbrio delicado, Rio de Janeiro, FGV, 2002, pp. 113159.
} 


\section{Quadro no 01: Competências do CMN e do $\mathrm{BCB}^{65}$}

\begin{tabular}{|c|c|c|c|}
\hline $\begin{array}{c}\text { Órgãos/ } \\
\text { Competências }\end{array}$ & $\begin{array}{c}\text { Atos Normativos } \\
\text { (capacidade normativa de } \\
\text { conjuntura) }\end{array}$ & $\begin{array}{l}\text { Atos Concretos e } \\
\text { Específicos } \\
\text { (competência } \\
\text { discricionária) }\end{array}$ & $\begin{array}{l}\text { Atos Concretos e } \\
\text { Específicos } \\
\text { (vinculados) }\end{array}$ \\
\hline CMN & $\begin{array}{l}\text { - disciplinar o crédito em todas } \\
\text { as suas modalidades } \\
\text { - limitar as taxas de juros e } \\
\text { qualquer outra forma de } \\
\text { remuneração de serviços } \\
\text { financeiros } \\
\text { - determinar a percentagem } \\
\text { máxima dos recursos que as } \\
\text { instituições financeiras } \\
\text { poderão emprestar a um } \\
\text { mesmo cliente ou grupo de } \\
\text { empresas } \\
\text { - expedir normas gerais de } \\
\text { contabilidade a serem } \\
\text { observadas pelas } \\
\text { instituições financeiras } \\
\text { - estipular índices e outras } \\
\text { condições técnicas sobre } \\
\text { encaixes, imobilizações e } \\
\text { outras relações patrimoniais, a } \\
\text { serem observadas pelas } \\
\text { instituições financeiras } \\
\text { - delimitar o capital } \\
\text { mínimo das instituições } \\
\text { financeiras privadas } \\
\text { - estipular as reservas } \\
\text { legais }\end{array}$ & & \\
\hline BCB & & $\begin{array}{l}\text { - realizar operações de } \\
\text { redesconto e empréstimo } \\
\text { a instituições financeiras } \\
\text { bancárias } \\
\text { - autorizar o } \\
\text { funcionamento de } \\
\text { cooperativas de crédito de } \\
\text { qualquer tipo }\end{array}$ & $\begin{array}{l}\text { - exercer a fiscalização } \\
\text { das instituições } \\
\text { financeiras e aplicar as } \\
\text { penalidades previstas } \\
\text { - promover a intervenção } \\
\text { ou a liquidação } \\
\text { extrajudicial das } \\
\text { instituições financeiras } \\
\text { públicas não federais e } \\
\text { nas privadas } \\
\text { - efetuar o controle dos } \\
\text { capitais estrangeiros }\end{array}$ \\
\hline
\end{tabular}

${ }^{65}$ Cf. Lei $4595 / 64$, arts. $4^{\circ}$ e $10^{\circ}$. Embora a legislação do sistema financeiro nacional seja, obviamente, muito mais ampla, é na lei de 1964 que encontramos a estrutura básica da regulação financeira brasileira. 


\begin{tabular}{|c|c|c|c|c|c|c|}
\hline ANO & Resolução & Circular & Carta-circd & nicadd & jun & Comu.Conj \\
\hline 2003 & 108 & 54 & 42 & 1155 & 2 & 0 \\
\hline 2002 & 153 & 103 & 89 & 1453 & 3 & 0 \\
\hline 2001 & 107 & 52 & 41 & 1006 & 2 & 0 \\
\hline 2000 & 129 & 64 & 59 & 906 & 0 & 0 \\
\hline 1999 & 97 & 102 & 58 & 634 & 1 & $\overline{0}$ \\
\hline 1998 & 126 & 56 & 52 & 569 & 1 & 0 \\
\hline 1997 & 109 & 66 & 69 & 539 & 1 & 0 \\
\hline 1996 & 122 & 80 & 101 & 482 & 2 & 0 \\
\hline 1995 & 89 & 120 & 82 & 571 & 1 & 0 \\
\hline 1994 & 99 & 135 & 92 & 693 & 1 & 0 \\
\hline 1993 & 67 & 135 & 88 & 510 & & 2 \\
\hline 1992 & 85 & 150 & 98 & 471 & & 2 \\
\hline 1991 & 107 & 235 & 107 & 383 & & 12 \\
\hline 1990 & 107 & 308 & 84 & 262 & & 4 \\
\hline 1989 & 113 & 148 & 0 & 0 & & \\
\hline 1988 & 122 & 137 & 0 & 0 & & \\
\hline 1987 & 198 & 174 & 1 & 3 & & \\
\hline 1986 & 166 & 120 & & & & \\
\hline 1985 & 84 & 76 & & & & \\
\hline 1984 & 102 & 71 & & & & \\
\hline 1983 & 106 & 86 & & & & \\
\hline 1982 & 64 & 79 & & & & \\
\hline 1981 & 49 & 74 & & & & \\
\hline 1980 & 79 & 109 & & & & \\
\hline 1979 & 87 & 76 & & & & \\
\hline 1978 & 48 & 53 & & & & \\
\hline 1977 & 46 & 33 & & & & \\
\hline 1976 & 57 & 44 & & & & \\
\hline 1975 & 40 & 39 & & & & \\
\hline 1974 & 43 & 21 & & & & \\
\hline 1973 & 33 & 30 & & & & \\
\hline 1972 & 33 & 21 & & & & \\
\hline 1971 & 40 & 21 & & & & \\
\hline 1970 & 37 & 19 & & & & \\
\hline 1969 & 23 & 8 & & & & \\
\hline 1968 & 26 & 14 & & & & \\
\hline 1967 & 35 & 41 & & & & \\
\hline 1966 & 31 & 48 & & & & \\
\hline 1965 & 14 & 21 & & & & \\
\hline
\end{tabular}

\section{Quadro no 02: Produção normativa do CMN e do $\mathrm{BCB}^{66}$}

${ }^{66}$ A pesquisa das normas do CMN e do BCB foi realizada no site do Banco Central (http://www.bcb.gov.br). As espécies normativas pesquisados foram os seguintes: (i) resoluções; (ii) circulares; (iii) cartas-circulares; (iv) comunicados; (v) decisões conjuntas; e, (viii) comunicados conjuntos. As resoluções são de competência do $\mathrm{CMN}$ e as circulares, por sua vez, são de competência da diretoria colegiada do Banco Central. Os departamentos do BCB são os responsáveis pela edição das cartas-circulares e dos comunicados. A decisão conjunta assim como o comunicado conjunto são emitidos pela CVM e pelo BCB. Para o melhor uso do sistema de busca no site, foi realizada a pesquisa ano a ano (1965-2003), restringindo-se os termos a cada tipo de ato normativo. O levantamento de dados foi finalizado em abril de 2004. 


\begin{tabular}{|c|c|c|}
\hline ANO & $\mathrm{CN}$ & $\mathrm{CMN} / \mathrm{BCB}$ \\
\hline 2003 & 7 & 1361 \\
\hline 2002 & 6 & 1801 \\
\hline 2001 & 12 & 1208 \\
\hline 2000 & 3 & 1158 \\
\hline 1999 & 10 & 892 \\
\hline 1998 & 12 & 804 \\
\hline 1997 & 11 & 784 \\
\hline 1996 & 8 & 787 \\
\hline 1995 & 12 & 863 \\
\hline 1994 & 11 & 1020 \\
\hline 1993 & 11 & 802 \\
\hline 1992 & 5 & 806 \\
\hline 1991 & 9 & 844 \\
\hline 1990 & 15 & 765 \\
\hline 1989 & 32 & 261 \\
\hline 1988 & 1 & 259 \\
\hline 1987 & 3 & 376 \\
\hline 1986 & 4 & 286 \\
\hline 1985 & 2 & 160 \\
\hline 1984 & 5 & 173 \\
\hline 1983 & 3 & 192 \\
\hline 1982 & 1 & 143 \\
\hline 1981 & 1 & 123 \\
\hline 1980 & 2 & 188 \\
\hline 1979 & 3 & 163 \\
\hline 1978 & 4 & 101 \\
\hline 1977 & 4 & 79 \\
\hline 1976 & 3 & 101 \\
\hline 1975 & 2 & 79 \\
\hline 1974 & 6 & 64 \\
\hline 1973 & 2 & 63 \\
\hline 1972 & & 54 \\
\hline 1971 & 5 & 61 \\
\hline 1970 & 4 & 56 \\
\hline 1969 & & 31 \\
\hline 1968 & 3 & 40 \\
\hline 1967 & 1 & 76 \\
\hline 1966 & 1 & 79 \\
\hline 1965 & 9 & 35 \\
\hline
\end{tabular}

\section{Quadro nº 03: Comparação produção normativa do Congresso Nacional e $\mathrm{BCB} / \mathrm{CMN}^{67}$}

\footnotetext{
${ }^{67}$ Este segundo quadro a comparação direta agregada entre a produção normativa do Congresso Nacional $(\mathrm{CN})$ e do Conselho Monetário Nacional (CMN) e Banco Central do Brasil (BCB). A primeira coluna traz o total de atos normativos produzidos pelo Congresso Nacional de 1965 a 2003: são emendas constitucionais, leis complementares e leis ordinárias. A segunda coluna, por sua vez, reúne os atos do $\mathrm{CMN}$ e $\mathrm{BCB}$, produzidos entre 1965 a 2003, que são resoluções, circulares, cartas-circulares, comunicados, decisões e comunicados conjuntos.
} 
Em todos esses casos, são criadas importantes restrições a princípios jurídicos como liberdade contratual, propriedade privada, livre iniciativa, livre concorrência, e mesmo ao princípio federativo. Em nome da racionalidade econômica, do combate à inflação e da estabilidade do sistema bancário, ou, num sentido oposto, em resposta a demandas do sistema político, à reivindicação de crescimento econômico, aos reclamos pela democratização do crédito e pela redução dos spreads bancários, todas as semanas pode-se assistir a uma série de normas que, embora não sejam provenientes do Poder Legislativo, alteram o estatuto da liberdade e da propriedade de pessoas físicas e jurídicas, visando à manutenção da estrutura do mercado ou ao alcance de objetivos políticos.

Deve-se insistir no paradoxo: embora de caráter conjuntural e, muitas vezes, efêmero ou experimental, essas normas exercem um indispensável papel na manutenção da estrutura do mercado financeiro. Essa capacidade normativa de conjuntura é funcional para o sistema econômico. A burocracia altamente qualificada que a exerce tem sua legitimidade reconhecida pelos agentes econômicos, que raramente se valem dos mecanismos jurídicos tradicionais para questionar a validade das normas editadas. À margem dos sagrados cânones do direito público brasileiro, as normas, por assim dizer, profanas que regem o mercado financeiro demonstram ter uma efetividade de fazer inveja à mais tradicional e respeitosa regra de qualquer código.

Se estivéssemos diante de um fenômeno passageiro, talvez a capacidade normativa de conjuntura não significasse nenhum problema para a democracia. Se a regulação financeira não passasse de um conjunto de tecnicalidades desprovidas de importância para o cidadão comum, provavelmente a alienação do direito público brasileiro não seria tão grave.

A moeda e o crédito, entretanto, não se encontram apenas no coração do sistema econômico. Da sua regulação adequada depende a própria coesão social. O contraste gritante entre a indiferença do formalismo jurídico e essa verdade básica de nossa sociedade, organizada em torno dos valores e da racionalidade de um mercado regulado, radicaliza o déficit democrático da burocracia reguladora. Diante desse quadro, faz-se necessária uma reflexão que, a partir da revelação do significado social da regulação financeira, oriente o pensamento jurídico para a busca de uma alternativa à racionalidade 
tecnocrática que nos oprime. Sem essa reflexão, desorientados, poderíamos sucumbir à tentação de resgatar a liberdade perdida por meio da opção mais fácil: pelo bloqueio dos poderes da burocracia, voltar ao laissez faire.

2. A peculiaridade da regulação financeira: a moeda como instituição social

O estudo comparado dos sistemas financeiros revela uma imensa diversidade institucional. Em cada país, distintas são as fórmulas adotadas para o estatuto e as características dos bancos centrais, as metas e instrumentos de política monetária, a regulamentação e a supervisão prudenciais e a fiscalização das instituições bancárias e não-bancárias, os sistemas de proteção dos depósitos, o tratamento conferido aos bancos estrangeiros, as instituições de fomento e de financiamento do desenvolvimento, o mercado de capitais, a relação empresa-banco e o regime dos fundos de pensão. ${ }^{68}$

Embora os bancos centrais venham atraindo boa parte das atenções, a multiplicidade de funções e de órgãos dos sistemas financeiros demonstra que o seu papel é melhor definido quando já foi escolhida a estrutura regulatória mais adequada para um determinado país. ${ }^{69}$

A evolução dos sistemas financeiros tornou inadequada a estrutura das agências regulatórias em muitos países. O surgimento de conglomerados financeiros, a inovação financeira $^{70}$, a complexidade crescente da atividade bancária, a obsolescência dos critérios convencionais de distinção entre tipos de firmas financeiras, e a internacionalização das

\footnotetext{
${ }^{68}$ Ver Carlos Kawall Ferreira, Maria Cristina Penido de Freitas e Gilson Schwartz, "Formato institucional do sistema monetário e financeiro: um estudo comparado", in: Marcos Antonio Macedo Cintra e Maria Cristina Penido de Freitas (org.), Transformações institucionais dos sistemas financeiros: um estudo comparado, São Paulo: Fapesp/Fundap, 1998, pp. 113-144.

${ }^{69}$ Passo a seguir, aqui, a argumentação de Charles Goodhart et al., Financial regulation: why, how and where now?, London and New York: Routledge, 1998, pp. 142-188.

${ }^{70}$ Cf. Robert Guttmann, How credit-money shapes the economy: the United States in a global economy, NewYork: M. E. Sharpe, 1994, particularmente o cap. 11, "Regulatory overhaul and the restructuring of U.S. banks", pp. 258-292, no qual o autor discorre sobre a inovação financeira. Ver também, do mesmo autor, "As mutações do capital financeiro", in: François Chesnais (coord.), A mundialização financeira: gênese, custos e riscos, São Paulo, Xamã: 1998, pp. 61-96.
} 
finanças são fenômenos que têm obrigado os formuladores de políticas públicas a enfrentar as seguintes questões: ${ }^{71}$

(a) qual o número apropriado de agências reguladoras?

(b) se não existe uma "mega-agência" regulatória, como repartir as competências?

(c) como garantir a coordenação entre as agências?

(d) a estrutura institucional tem um peso importante nos custos da regulação?

(e) qual o papel das autoridades antitruste?

(f) qual o papel da auto-regulação?

(g) quais os mecanismos institucionais que garantem a cooperação internacional entre agências nacionais?

(h) qual deve ser o grau de independência e de responsabilização (accountability) das agências?

O problema do número de agências, por si só, já é complicadíssimo. A favor da agência reguladora única, costuma-se afirmar que sua "economia de escala" propiciaria custos institucionais menores. Os problemas de competências concorrentes ou duplicadas seriam evitados. Os custos de monitoramento impostos às firmas reguladas diminuiriam. A agência seria de fácil reconhecimento pelos regulados e pelos consumidores. Ela teria uma maior especialização, e estaria sujeita a um maior grau de responsabilização.

Entretanto, os críticos da opção pela agência única sustentam que continuam existindo diferenças funcionais marcantes entre bancos, companhias de seguro e intermediários que operam no mercado de valores mobiliários: o tipo de atividade, de contrato e os efeitos da intermediação em cada caso não são iguais. Desse modo, teriam que surgir, no interior da mega-agência, departamentos especializados, não havendo garantia de que a sua coordenação seria mais eficiente do que aquela exigida entre agências num sistema pluralista. Além disso, a adoção da agência única poderia implicar

${ }^{71}$ Cf. Charles Goodhart, Financial regulation: why, how and where now?, ob. cit., pp. 143-4; James H. Cheek, III. "Approaches to market regulation", in: Fidelis Oditah (ed.), The future for the global securities market: legal and regulatory aspects, Oxford: Clarendon Press, 1996, pp. 243-245. 
uma excessiva burocratização e uma indesejável concentração de poder, eliminando-se a concorrência saudável que há entre as agências num sistema pluralista.

Se rejeitada a opção pela "mega-agência", a discussão volta-se para os critérios de repartição das competências das várias agências criadas. Para tanto, pode ser considerada a distinção entre bancos e instituições não bancárias; entre instituições que têm dimensão sistêmica e instituições que não a têm; entre instituições que envolvem esquemas de proteção ao investidor ou ao depositante e instituições sem essa característica; e entre atacado e varejo. Somam-se a estas questões relativas ao direito antitruste.

Sempre tendo em vista a busca da estabilidade sistêmica e da proteção ao consumidor, uma estrutura institucional pluralista terá um número maior ou menor de agências, dependendo da posição assumida quanto à validade da distinção entre banking, insurance e securities. Portanto, é somente no contexto de uma visão global de um sistema financeiro que se pode pensar o papel do banco central.

Embora não possa ser negada a necessidade de coordenação entre as cúpulas de funcionários responsáveis pela política monetária e pela regulação bancária, a questão de o órgão supervisor estar dentro ou fora da autoridade monetária depende da percepção da adequada distribuição de poder e responsabilidade - o que é histórica e culturalmente contingente. $^{72}$

A estrutura pluralista encontra-se envolvida, portanto, em problemas de conflito (positivo e negativo) de competências. Nos EUA, por exemplo, sete leis ${ }^{73}$ e nove agências federais ${ }^{74}$ compõem a estrutura regulatória do mercado de capitais. Esta fragmentação gera ineficiência, desperdício e insegurança jurídica. Projetos de consolidação legislativa e de

\footnotetext{
${ }^{72}$ Cf. Charles Goodhart, ob. cit., p. 173. Sobre essa questão específica, ver também Charles Goodhart/Dirk Schoenmaker, "Should the functions of monetary policy and banking supervision be separated?", Oxford Economic Papers, New Series 47-4 (1995), pp. 539-560 (argumentando que não há um argumento definitivo que leve à opção pela manutenção das funções de política monetária e regulação/supervisão bancárias nas mãos do banco central ou à sua separação).

73 Securities Act of 1933, Securities Exchange Act of 1934, Public Utility Holding Company Act of 1935, Trust Identure Act of 1939, Investment Company Act of 1940, Investment Advisers Act of 1940 e Securities Investor Protection Act of 1970.

74 Securities and Exchange Comission, Federal Reserve Board, Department of Treasury, Department of Labor, Commodities Future Trading Comission, Office of the Comptroller of the Currency, Federal Deposit Insurance Corporation, Securities Investor Protection Corporation, Pension Benefit Guaranty Corporation (cf. James H. Cheek, III. “Approaches to market regulation”, ob. cit., p. 246).
} 
fusão das agências têm sido discutidos nos últimos vinte anos, mas nenhum foi adotado. ${ }^{75}$ A ausência de uniformidade na legislação e os "instintos naturais de competição regulatória" ${ }^{\text {76 }}$ têm sido combatidos mediante esforços de cooperação institucional.

Ora, se em países do centro do capitalismo internacional a tarefa de regulação do sistema financeiro enfrenta tantas dificuldades, o que se esperar da periferia? Em países como o Brasil, a esperança de democratização do acesso ao crédito e aos serviços financeiros em geral deve vir acompanhada de uma maior reflexão sobre o desenho institucional do sistema financeiro como um todo. A democratização do mercado não pode prescindir de um arcabouço regulatório e de instituições financeiras sólidas. A Constituição foi promulgada há mais de uma década e o art. 192 já foi até mutilado, ${ }^{77}$ mas a tão reclamada regulamentação do sistema financeiro não veio.

A regulação financeira não é peculiar apenas pela complexidade e diversidade de suas configurações institucionais. Apesar da diversidade de modelos, há algo comum a todos eles: os amplos poderes conferidos aos órgãos reguladores. Nos debates travados durante a tramitação do projeto de lei que criou a Financial Services Authority (FSA), a mega-agência reguladora inglesa do mercado financeiro, críticas ressaltavam que a FSA reuniria poderes típicos de "legislator, investigator, prosecutor, judge, jury and executioner" 78

A literatura sobre regulação do mercado financeiro costuma apontar uma série de razões para justificar esses poderes, de caráter, inclusive, "legislativo", ressaltando o interesse público subjacente. Todas elas podem ser subsumidas à rubrica "falhas de mercado". Como essas falhas de mercado, principalmente as externalidades e a assimetria de informações, seriam maiores do que as falhas do Estado-regulador, a regulação externa impor-se-ia sobre a auto-regulação privada calibrada por uma lógica concorrencial. ${ }^{79} \mathrm{~A}$

\footnotetext{
${ }^{75}$ Cf. James H. Cheek, III, ob. cit., p. 245-246.

${ }^{76}$ Idem, p. 247.

${ }^{77}$ Como é sabido, a Emenda Constitucional no 40 revogou todos os incisos da redação original do art. 192, além de ter modificado o caput, trocando a expressão "lei complementar" por "leis complementares". Esta última alteração facilitaria, segundo uma idéia amplamente difundida, que o sistema financeiro fosse finalmente regulamentado, ao permitir que essa regulamentação fosse feita de forma "fatiada".

78 Tyrie, "Forging a regulation sledgehammer", Financial Times, 10 April 2000, apud Alan Page, "Regulating the regulator - a lawyer's perspective on accountability and control", in Eilís Ferran and Charles Goodhart (eds.), Regulating financial services and markets in the twenty first century, Oxford-Portland, Oregon: Hart Publishing, 2001, p. 127.

${ }^{79}$ Cf. Charles Goodhart et al., Financial regulation: why, how and where now?, ob. cit., pp. 3-4.
} 
regulação financeira teria três objetivos principais: ${ }^{80}$ (i) a manutenção da estabilidade sistêmica, (ii) a garantia da segurança e do bom funcionamento das instituições financeiras e (iii) a proteção do consumidor. Considerando-se esses objetivos, sua rationale teria sete componentes: (i) problemas sistêmicos potenciais associados às externalidades; (ii) a correção de outras falhas e imperfeições do mercado; (iii) a necessidade de monitoramento das instituições financeiras e das economias de escala existentes no setor; (iv) a necessidade de garantir a confiança do consumidor de serviços financeiros; (v) a possibilidade de ocorrência de grid lock, com os problemas de seleção adversa e de risco moral a ele associados; (vi) o risco moral decorrente da própria tendência que os governos manifestam de criar ou manter a rede de segurança, mediante mecanismos como o lender of least resort, o seguro de depósito e esquemas de compensação; (vii) a demanda do consumidor por regulação, buscando segurança e custos mais baixos.

As externalidades estão associadas às questões sistêmicas: a regulação para prevenção de problemas sistêmicos (regulação sistêmica) justifica-se na medida em que os custos sociais da quebra de instituições financeiras são superiores aos custos da intervenção estatal. O problema é mais grave no caso dos bancos, devido ao papel que eles exercem no sistema econômico: uma crise no setor bancário pode desestabilizar o esquema de financiamento do setor produtivo e o sistema de pagamentos, levando ao colapso toda a economia.

Os bancos têm uma estrutura patrimonial sui generis: enquanto os empréstimos (ativos) somente são exigíveis depois de um certo prazo, ou seja, têm baixa liquidez, os depósitos (passivos) ficam disponíveis para a demanda a qualquer momento pelo cliente. $\mathrm{O}$ que garante sua força e o valor dos ativos que ele detém, em meio a essa potencial instabilidade, é sua credibilidade. É a crença na higidez dos bancos que lhes permite multiplicar moeda pela concessão de empréstimos e correspondente criação de depósitos. Se esta credibilidade, por qualquer motivo, é abalada, um banco pode não resistir a uma corrida bancária. O problema, porém, não se exaure em uma única instituição. A externalidade diz respeito exatamente à possibilidade de a insolvência de uma instituição

\footnotetext{
${ }^{80}$ Sigo de perto, daqui por diante, David Llewellyn, "The economic rationale for financial regulation", FSA Occasional Paper, London, April 1999. O trabalho de Llewellyn é, em grande parte, uma resposta à crítica liberal que George Benston tem desenvolvido contra a regulamentação dos mercados financeiros ("Regulating financial markets: a critique and some proposals", Hobart Paper n. 135, London: Institute of Economic Affairs, 1998).
} 
bancária contaminar outros bancos, provocando um efeito dominó que compromete o conjunto.

A insolvência de um banco possui um perverso efeito destruidor de riqueza. Como somente os bancos possuem a informação sobre seus clientes, só eles conhecem o valor real de seus ativos. Se uma instituição importante sofre uma corrida bancária, ela é obrigada, para atender aos saques, a transformar rapidamente e com prejuízo ativos ilíquidos em moeda. Se ela quebra, os ativos dos demais bancos podem desgraçadamente experimentar um processo de desvalorização perante terceiros externos a eles. Inseguros, os clientes dessas outras instituições podem correr para também sacar o seu dinheiro, pois sabem que somente os primeiros que assim procederem é que realmente conseguirão efetuar o saque. O grau peculiarmente elevado de integração entre os bancos - decorrente das posições que detêm entre si -, potencializa, portanto, o risco do contágio.

Mesmo que se reconheça um certo exagero nessa preocupação, admitindo-se que seja baixa a probabilidade de a quebra de um banco assumir dimensões sistêmicas, a gravidade de uma insolvência generalizada justificaria per se a regulação sistêmica: "[t]hus, regulation to prevent systemic problems may be viewed as an insurance premium against 'low-probability-high-seriousness'risks". ${ }^{81}$

A gravidade do risco sistêmico não implica que somente ele justifique a regulação financeira. Esta pode e deve estar voltada também para os eventos que não têm dimensão sistêmica, configurando uma regulação prudencial. Dificilmente o cliente médio de um banco é capaz de avaliar a consistência de sua instituição. Buscar essa informação lhe tomaria muito tempo e dinheiro. Mesmo para os mais experientes, não seria uma tarefa fácil acompanhar pari passu, por exemplo, as alterações das posições de um banco que costuma realizar operações de risco acima da média. Entretanto, por que o Estado deveria regular relações que não têm implicação sistêmica? A resposta oferecida pela literatura pró-regulação reside na distinção entre serviços financeiros e serviços não financeiros. É inegável a relevância, para os trabalhadores e consumidores de determinada empresa comercial, da sua falência: perdem-se empregos, os consumidores que realizaram compras recentes jamais verão suas mercadorias etc. Entretanto, não se aceita, por causa disso, nem

\footnotetext{
${ }^{81}$ David Llewellyn, “The economic rationale for financial regulation”, ob. cit., p. 16.
} 
política nem juridicamente, que os revendedores de eletrodomésticos, por exemplo, sejam fortemente regulados como se fossem fornecedores de serviços públicos. É isso, entretanto, que ocorre com as instituições financeiras. Ninguém aceitará a idéia de que elas são prestadoras de serviços públicos, mas elas são objeto de intensa e complexa regulação estatal, independentemente do chamado "risco sistêmico". David Llewellyn aponta sete razões para isso: ${ }^{82}$ (i) instituições financeiras geralmente trabalham com valores maiores; (ii) quando uma empresa não financeira quebra, o consumidor mantém consigo a mercadoria que já comprou e recebeu; (iii) enquanto o produto adquirido de uma empresa não financeira tem seu valor diminuído com o tempo, o que implica a progressiva redução de seu custo de reposição, no caso de um produto financeiro, não somente o valor aumenta com o tempo, como essa é a própria premissa do contrato que o originou; (iv) a transferência de contas de um banco para outros tem custos e desgastes decorrentes dos problemas de transferência de informação entre bancos; (v) as instituições financeiras geralmente desenvolvem com seus clientes uma relação de longo prazo, ao contrário do que ocorre com as transações não financeiras, que se exaurem, por exemplo, com as obrigações de um contrato de compra e venda; (vi) a instituição financeira freqüentemente desenvolve com seu cliente uma relação de confiança, assumindo a gestão de seu patrimônio; (vii) a maioria das quebras de estabelecimentos não financeiros têm pequeno impacto nos consumidores.

Em resumo, o que justificaria a regulação prudencial seria a natureza peculiar dos produtos, serviços e contratos financeiros. ${ }^{83}$ Toda a argumentação de Llewellyn, representativa da literatura favorável à regulação estatal dos mercados financeiros, é construída como uma resposta às críticas que autores como George Benston ${ }^{84}$ fazem a essa regulação. Para Benston, os produtos financeiros nada têm de especial que os distinga das demais mercadorias e serviços. Tal como ocorre com os demais bens, o consumidor de serviços financeiros poderia muito bem ser beneficiado pela concorrência entre as instituições financeiras, pela análise da reputação destas e pela publicidade de informações (disclosure). Haveria sempre, ainda segundo Benston, a possibilidade de o consumidor recorrer ao Judiciário sempre que se considerasse lesado.

\footnotetext{
${ }^{82}$ David Llewellyn, "The economic rationale for financial regulation”, ob. cit., pp. 18-19.

${ }^{83}$ Por razões meramente estilísticas, toda vez que eu utilizar isoladamente os termos "produtos", "serviços" ou "contratos", estarei me referindo, na verdade, ao conjunto de produtos, serviços e contratos financeiros.

${ }^{84}$ George Benston, "Regulating financial markets: a critique and some proposals", Hobart Paper n. 135, London: Institute of Economic Affairs, 1998, apud David Llewellyn, ob. cit., p. 36.
} 
A resposta de Llewellyn consiste não somente em demonstrar os custos e a incerteza do processo judicial, mas principalmente em explicitar os altos custos de transação do consumo de produtos e serviços financeiros. Estes seriam credence goods, ou seja, bens cuja qualidade só pode ser verificada após a sua aquisição, a um custo determinado, podendo ocorrer, inclusive, casos em que nunca será possível para o consumidor avaliar essa qualidade. As transações financeiras envolvem contratos incompletos, ou seja, contratos cujo valor é determinado em grande medida pelo comportamento do fornecedor após a contratação do serviço. Llewellyn dá o exemplo do fundo de pensão, cujo gestor revela-se, depois de algum tempo, incompetente ou desonesto, comprometendo a poupança dos participantes do fundo, que não tinham como identificar esse problema quando nele ingressaram. A racionalidade limitada (bounded rationality) do indivíduo consumidor não permite que ele obtenha e processe de forma satisfatória as informações necessárias para tomar uma decisão e evitar as empresas ou produtos ruins. ${ }^{85}$ Llewellyn oferece, então, um rol extenso de características que distinguiriam os serviços financeiros dos não-financeiros: ${ }^{86}$

(i) os serviços financeiros não são contratados com freqüência, o que impede que o consumidor adquira experiência para lidar com eles;

(ii) um produto financeiro não tem garantia, nem pode ser testado no momento da sua aquisição;

(iii) se a instituição financeira torna-se insolvente durante o vencimento do contrato, o valor deste pode se perder;

(iv) é difícil obter informação sobre a confiabilidade do serviço ou da instituição;

(v) o valor do produto não é claro no momento da aquisição, o que significa que o consumidor não tem como saber, na verdade, se o que ele está adquirindo é bom ou não;

(vi) não há transparência: é difícil checar a veracidade do que o fornecedor alega;

(vii) o valor do serviço ou produto depende do comportamento do fornecedor ao longo do tempo;

(viii) o bem estar futuro do consumidor depende da execução satisfatória do contrato;

\footnotetext{
${ }^{85}$ David Llewellyn, ob. cit., p. 35.

${ }^{86}$ Ibid., pp. 37-38.
} 
(ix) é geralmente fácil para o vendedor de produtos financeiros omitir informações do consumidor ou induzi-lo a erro;

(x) a aquisição de um produto financeiro com freqüência cria uma relação na qual a instituição assume a responsabilidade pela gestão da poupança ou do investimento do cliente;

(xi) a reputação da instituição não ajuda muito o consumidor, pois se algo de desabonador ocorre com ela, comprometendo sua imagem, já pode ser tarde demais para o consumidor reverter a situação e preservar seu patrimônio.

Essa impressionante relação didaticamente fornecida por Llewellyn das características peculiares dos produtos, serviços e contratos financeiros dá uma clara idéia dos altos custos de transação implicados na sua aquisição. A regulação prudencial impõese, portanto, para diminuir a probabilidade de insolvência e de práticas desonestas das instituições financeiras.

A delegação pelos consumidores a agências reguladoras da tarefa de monitoramento das instituições financeiras pode ser considerada racional, em termos econômicos, na medida em que é mais eficiente, devido às economias de escala e à especialização técnica desses órgãos. Se cada consumidor tivesse que realizar esse monitoramento por conta própria, haveria duplicação de tarefas e um enorme investimento de tempo e recursos, totalmente desproporcional em relação à quantidade de aquisições que ele faria.

De tudo o que foi dito até aqui, percebe-se a importância do problema da assimetria de informação para a justificativa da regulação financeira. Consumidores avessos ao risco, conscientes de seu déficit de informação e desconfiados de que há produtos muito ruins no mercado - essas são as condições que levam à diminuição do consumo ou, numa situação extrema, ao colapso do mercado. Trata-se, aqui, do conhecido problema dos "limões" que George Akerlof desenvolveu em seu famoso artigo de 1970. 87 "Limões” (lemons) é a expressão utilizada para designar os carros usados de má qualidade, comprometidos por sérios problemas que não são identificáveis à primeira vista, mas geralmente só quando o

${ }^{87}$ George Akerlof, “The market for 'lemons': quality, uncertainty and the market mechanism”, Quarterly Journal of Economics 84 (1970), pp. 488-500. Outra referência importante é o trabalho de Joseph Stiglitz, Bruce Greenwald e Andrew Weiss, "Information imperfections in the capital market and macroeconomic fluctuations", American Economic Review 74 (1984), pp. 194-199. 
comprador já levou o "limão" - no Brasil diríamos "abacaxi" - para sua garagem. O papel da regulação seria, portanto, estabelecer e zelar por padrões mínimos de qualidade, removendo os "limões" do mercado.

A desconfiança do consumidor tem um fundamento racional. A estrutura peculiar da atividade financeira, lastreada em contratos de longo prazo, cujo valor é indefinido no momento da celebração, cria a oportunidade para que as instituições financeiras adotem estratégias arriscadas e condutas prejudiciais para o consumidor, em busca da rentabilidade maior no curto prazo - contando com a hipótese mais que plausível de que os consumidores individualmente não perceberão isso. Surge, assim, um grid lock: como cada instituição financeira não acredita que suas concorrentes adotarão condutas corretas perante o consumidor, todas elas terminam por agir de forma incorreta. As que não o fazem, deixam o mercado.

Esse processo cria dois efeitos perversos. O primeiro deles, já delineado, é a seleção adversa: as empresas que adotam práticas corretas tendem a deixar o mercado devido à sua insatisfação em relação ao preço que o consumidor desconfiado está disposto a pagar por seus produtos. Em outras palavras, desenvolve-se um tipo de concorrência que deteriora o padrão de qualidade dos produtos financeiros, pois, devido à assimetria de informação, a formação dos preços no mercado tende à média entre os preços dos produtos das "boas" empresas e aqueles das "más" empresas . O segundo é uma forma de risco moral: as instituições com práticas corretas tendem a adotar o comportamento de suas rivais mais lucrativas e menos escrupulosas. Nessa dinâmica, fica difícil acreditar, como faz Benston, que as empresas têm um interesse racional em agir de acordo com os interesses dos seus clientes para, por exemplo, preservar sua reputação.

A regulação impõe-se, portanto, para romper o grid lock, estabelecendo padrões mínimos de conduta e de qualidade que todas as instituições devem seguir. A medida mais inteligente para a definição desses parâmetros pode ser dada pela resposta à seguinte questão: se as instituições tivessem certeza de que seus concorrentes obedeceriam a um mesmo conjunto de regras, que grau de exigência seria razoável e factível impor?

Existe ainda o risco moral criado pela própria atuação estatal: os mecanismos de seguro de depósito, do emprestador de última instância e outras modalidades quaisquer de 
compensação do consumidor, concebidos para a montagem de uma rede de proteção, podem engendrar um comportamento arriscado por parte dos agentes econômicos. Os consumidores, tranqüilizados por contarem com um esquema de compensação, podem ser negligentes na escolha da instituição financeira, privilegiando, na sua decisão, aquelas que prometem maior rentabilidade - mesmo que não sejam as mais confiáveis. As instituições financeiras, por seu turno, também podem se sentir tentadas a assumir riscos maiores, já que contam com a rede de proteção. Isso ocorre, com efeito, porque o agente econômico percebe que a rede de proteção lhe permite repassar o seu risco para terceiros. O papel da regulação aqui é, portanto, diminuir a probabilidade de risco moral. Curiosamente, não se trata, no caso, de uma falha de mercado, mas sim de uma distorção provocada pela própria atuação protetora do Estado.

Por fim, a regulação financeira também é justificada, em termos econômicos, racionais, pela demanda dos consumidores. O consumidor racional aceita assumir - como contribuinte - os custos da estrutura regulatória porque ela lhe diminui os custos de transação, processa e publiciza as informações que ele precisa para tomar decisões, aumenta a segurança de suas transações, supre sua falta de experiência na lide com produtos financeiros. Mais ainda: a regulação lhe aparece como uma alternativa mais eficiente do que a busca de compensação posterior no Judiciário, por exemplo, já que a regulação teria um efeito preventivo. Assim, o consumidor racional não somente aceita a atuação estatal no setor, mas nutre por ela uma demanda: "[i]n effect, a risk-averse consumer may willingly pay a high insurance premium through regulation" ${ }^{88}$

A justificativa de caráter eminentemente econômico desenvolvida por Llewellyn, embora importante, é insuficiente para uma compreensão mais profunda da ampla capacidade normativa de conjuntura que instrumentaliza a regulação financeira. Essa insuficiência deriva do paradoxo inerente ao discurso de Llewelyn: em sua reação à crítica liberal de Benston, ele afirma, a todo momento, sua tentativa de demonstrar que os produtos, serviços e contratos financeiros constituem uma mercadoria sui generis. A forma como faz isso, todavia, é pagando o alto preço de transformar a própria regulação numa mercadoria ordinária, que é "demandada" pelo consumidor.

${ }^{88}$ Ibid. p. 31. 
Em contraposição a essa perspectiva do mainstream da ciência econômica - a do homo oeconomicus -, Karl Polanyi elaborou, com base em estudos de antropologia econômica, uma visão mais ampla da dimensão do econômico. Ele distinguiu dois significados para o termo: o material (substantive) e o formal (formal). ${ }^{89} \mathrm{O}$ significado material do econômico vem da dependência da sobrevivência humana em relação à natureza e àqueles com quem ele convive. Diz respeito à interação do homem com seu meio natural e social, em busca dos meios de satisfação de suas necessidades. O significado formal vem do caráter lógico da relação meio/fim. Refere-se às regras sobre a escolha de meios, que são escassos - a lógica da ação racional. Esta última tornou-se, em torno do conceito de mercado, por um exercício metodológico arbitrário, a própria definição do econômico. O que Polanyi sustenta é que somente o significado material do econômico pode atender à ambição metodológica de construir um quadro mais amplo para a análise do fenômeno econômico:

"The human economy, then, is embedded and enmeshed in institutions, economic and noneconomic. The inclusion of noneconomic is vital. For religion or government may be as important for the structure of economy as monetary institutions or the availability of tools and machines themselves that lighten the toil of labor". 90

O fenômeno econômico, submerso (embedded) nas instituições, só pode ser plenamente compreendido mediante o estudo de suas formas de integração, ou seja, padrões que conferem unidade e estabilidade à economia. Empiricamente, verifica-se que esses padrões são três: reciprocidade, redistribuição e troca. Eles são identificáveis em diferentes setores e níveis da economia. Nenhum deles é dominante de modo a permitir uma classificação empírica dos sistemas econômicos. A cada uma dos padrões correspondem arranjos institucionais que garantem a integração. Isso significa que os padrões de integração não são o resultado da soma de condutas individuais. A idéia de embeddedness leva a sério uma perspectiva institucional da economia: ${ }^{91}$

\footnotetext{
${ }^{89}$ Passo, a partir daqui, a resumir as principais idéias que Polanyi desenvolveu num artigo publicado originalmente em 1957: "The economy as instituted process", republicado em Mark Granovetter and Richard Swedberg (eds.), The sociology of economic life, Oxford: Westview Press, 1984, pp. 29-51.

${ }^{90}$ Ibid., p. 34.

${ }^{91}$ Ibid., p. 35.
} 
"[... If], in any given case, the social effects of individual behaviour depend on the presence of definite institutional conditions, these conditions do not for that reason result from the personal behaviour in question. ${ }^{92}$

A reciprocidade, por exemplo, não pode existir sem um ambiente que esteja organizado simetricamente $;^{93}$ a redistribuição, sem centros de alocação que coordenam a coleta e posterior divisão de bens; as trocas, sem um sistema de formação de preços num mercado. Essas formas de integração não configuram, como faz questão de ressaltar Polanyi, "estágios" de desenvolvimento, mas padrões que se combinam em diferentes sociedades em distintos momentos históricos. A redistribuição, por exemplo, está presente nas tribos primitivas baseadas na caça, nos amplos sistemas de estocagem do Antigo Egito, Suméria, Babilônia e Peru, ${ }^{94}$ no Império Romano tardio, na ex-União Soviética - esta última um exemplo extremado do princípio da redistribuição. ${ }^{95}$ Ela é também claramente uma forma de integração que informa o Welfare State ${ }^{96}$ - aliás, exatamente pelo fato de a ciência econômica alimentar uma concepção tão estreita do econômico é que a racionalidade do Welfare State é considerada "não-econômica".

Essa concepção estreita consiste em tomar a parte pelo todo, ou seja, em assumir como forma universal do econômico o que é tão somente uma de suas manifestações institucionais: o mercado. É mediante essa operação que a ciência econômica predominante reduz o locus da troca ao mercado; o comércio e o dinheiro são falsamente apresentados como funcionais ao sistema de preços do mercado. Segundo Polanyi, a antropologia e a história desmistificam essa redução arbitrária do econômico:

"The long periods of history when reciprocity and redistribution integrated the economy and the considerable ranges within which, even in modern times, they continued to do so, were put out of bounds by a restrictive terminology. ${ }^{97}$

A análise que Polanyi faz das práticas comerciais demonstra como o mercado é apenas uma de suas formas institucionais. Durante milênios, por exemplo, o comércio

\footnotetext{
${ }^{92}$ Ibid., p. 36.

${ }^{93}$ Polanyi baseia-se nos trabalhos de Richard Thurnwald e Bronislaw Malinowski.

${ }^{94}$ Ibid., p. 37.

${ }^{95}$ Ibid., p. 39.

${ }^{96}$ Ibid., p. 37-38.

${ }^{97}$ Ibid., p. 40.
} 
entre impérios era praticado como envio de presentes (gift trade), com base em relações de reciprocidade. O comércio administrado (administered trade), do qual o porto comercial é a maior expressão, também foi bastante comum. Em termos históricos, a prática comercial de caráter necessariamente bilateral, com base num sistema de preços, ou seja, o comércio praticado no âmbito de um mercado, é a terceira forma institucional que surge. A questão que se põe para o estudioso, portanto, é a seguinte: "when and how did trade become linked with markets?". 98

Da mesma forma que o comércio, o dinheiro também só pode ser corretamente compreendido se sua forma geral não for reduzida à forma específica que ele assume no mercado. Uma definição material do dinheiro abrange os usos que determinados objetos quantificáveis têm: pagamento, padrão ou medida de riqueza e troca. A função de pagamento consiste no cumprimento de uma obrigação. Sempre foi muito comum, configurando situações que variavam do pagamento do dote a tributos. A função de contabilização da riqueza foi essencial, por exemplo, para a elasticidade de um sistema redistributivo, ao facilitar o estabelecimento de equivalências entre mercadorias como lã e óleo. Na ausência da forma mercado, a função de troca do dinheiro era secundária:

\footnotetext{
"The surprising reluctance of the great trading peoples of antiquity such as Tyre and Carthage to adopt coins, that new form of money eminently suited for exchange, may have been due to the fact that the trading ports of the commercial empires were not organized as markets, but as 'ports of trade'.,99
}

E mais que isso: o dinheiro tinha finalidades especiais. Objetos distintos podiam ser utilizados para cumprir funções distintas do dinheiro. Polanyi dá o exemplo da Babilônia de Hamurábi, na qual a cevada era o meio de pagamento, a prata, o padrão universal, e ambos eram usados juntamente com lã e óleo como meios de troca. O dinheiro sempre esteve, portanto, submerso nas instituições. Revela-se um fenômeno bem mais complexo do que aquele descrito nos manuais de Economia, nos quais sua complexa e variante forma é reduzida à forma específica que ele assume no mercado. ${ }^{100}$

\footnotetext{
${ }^{98}$ Ibid., pp. 44-45.

${ }^{99}$ Ibid., p. 46.

${ }^{100}$ Ibid., p. 47.
} 
Polanyi não se restringe a rebater a identidade entre comércio e mercado. Sua análise do próprio mercado - como sempre, numa perspectiva material - , revela a diversidade institucional deste, que foi obscurecida pelo conceito formal do mecanismo de preços formados a partir da oferta e da demanda. O preço é visto como uma forma de equivalência característica de economias integradas pela troca. Equivalência é a categoria geral que Polanyi utiliza para descrever como as distintas formas de integração realizam a comparação entre bens. Em sistemas baseados na reciprocidade, o equivalente designa o que é adequado em relação às partes simétricas; no caso da redistribuição, o equivalente designa a relação quantitativa entre bens de diferentes tipos que podem ser aceitos para o pagamento de tributos. O preço nada mais é do que uma nova forma de equivalência, própria do mercado. Historicamente, ele surge a partir das formas de equivalência associadas à reciprocidade e à redistribuição. ${ }^{101}$

O sentido material do econômico desenvolvido por Polanyi implica uma ruptura com o individualismo metodológico que tem caracterizado a ciência econômica. Sua conseqüência mais profunda consiste em revelar o caráter não natural do mercado. Submerso (embedded) na vida social, o mercado nada mais é do que uma das diversas formas institucionais que o econômico pode assumir. Ele não é, como quer o saber econômico mainstream, a própria forma universal do econômico, e nem tampouco possui uma única configuração institucional. Seus elementos podem ser combinados e recombinados de diversas formas, ao mesmo tempo em que ele pode conviver com formas de integração baseadas na reciprocidade e na redistribuição.

Houve, porém, um processo histórico no qual o livre mercado ameaçou emergir com uma força extraordinária, enquanto instância autônoma, submetendo toda a vida social à lógica das trocas, transformando as coisas mais sagradas em meras mercadorias: o trabalho (o homem) e a terra (a natureza). Essa foi a grande transformação que Polanyi descreveu em sua grande obra, publicada em 1944 - a tentativa fadada ao malogro de implantação da utopia de uma economia de mercado auto-regulado. $\mathrm{Na}$ ascensão do liberalismo econômico no século XIX, ele encontrou as raízes da Primeira Guerra Mundial, da Grande Depressão e do fascismo.

${ }^{101}$ Ibid., pp. 48-51. 
Em sua análise, a terra e o trabalho são mercadorias fictícias, ou seja, jamais poderiam ter sido tragadas pelo processo de comodificação pelo que ele chamou de "moinhos satânicos". Trata-se, aqui, de pressupostos normativos de Polanyi, que ele busca ancorar nos estudos de antropologia e história econômica. Na medida em que as forças do mercado tentam transformar o trabalho e a terra em mercadorias ordinárias, a sociedade reage. Ele estuda o caso da evolução da legislação social e do trabalho na Inglaterra Statute of Artificers (1563), a Poor Law (1601), e a Speenhamland Act, revogada em 1834, o que significou a criação de um mercado de trabalho naquele país. A política "anticercamento" dos Tudors e dos primeiros Stuarts é lembrada como uma espécie de protesto contra o uso lucrativo da propriedade fundiária. Polanyi constrói, de forma original e dramática, a narrativa na qual a lógica do mercado transpõe os obstáculos à sua expansão, subordina a própria substância da sociedade às suas leis, e como isso desperta uma reação na forma de políticas e instituições voltadas para a proteção da terra e do trabalho - o "duplo movimento" que caracteriza a história social do século XIX. ${ }^{102}$

O trabalho de Polanyi tem uma importância especial para a regulação financeira. Tudo o que foi dito até aqui se aplica também, segundo ele, à terceira mercadoria fíctícia: o dinheiro. Se em seu importante artigo de 1957 ele apontou o significado material do dinheiro, em contraposição à simplificação formal da teoria dominante, nos capítulos dezesseis e dezessete de $A$ Grande Transformação ele já abordara de forma mais detalhada o tema do dinheiro, ao discorrer sobre o colapso do padrão-ouro e o papel do banco central moderno. ${ }^{103}$ Sua intenção é demonstrar como a atuação desta entidade, inserida no duplo movimento, corresponde a uma tentativa de proteção contra os mecanismos de mercado, a exemplo do que ocorreu com o trabalho e a terra. Com o banco central, porém, o alvo imediato da proteção não é nem o homem nem a natureza, mas o conjunto dos empreendimentos capitalistas produtivos. Polanyi denuncia, assim, um duplo paradoxo: de um lado, os negócios tiveram que ser protegidos do próprio mercado, no qual eles eram gerados, e, de outro, esta própria medida - a centralização do controle da moeda e do crédito no banco central - terminou por contribuir para a derrocada do sistema monetário internacional. $^{104}$

${ }^{102}$ Cf. Karl Polanyi, The great transformation: the political and economic origins of our time, $2^{\text {nd }}$ ed., Boston: Beacon Press, 2001, pp. 71-107.

${ }^{103}$ Ibid., pp. 201-209.

${ }^{104}$ Ibid., p. 201. 
O primeiro paradoxo pode ser explicado pela forma como estava organizada a oferta de moeda na economia de mercado durante o período do padrão-ouro. As empresas estavam vulneráveis a distorções deflacionárias por razões exclusivamente monetárias. Assim, havia o sério risco de que, abandonado à sua própria lógica, o mercado destruísse "seus próprios filhos", ${ }^{105}$ se ocorresse uma escassez prolongada de moeda-mercadoria. Se o sistema baseado nesta última era o único que o livre mercado poderia produzir, forçoso era reconhecer sua incompatibilidade com a produção industrial. ${ }^{106}$

Ao coordenar a oferta de moeda no âmbito nacional, o banco central propiciava a diluição dos efeitos deflacionários por todo o sistema econômico, ${ }^{107}$ preservando o sistema produtivo. Essa coordenação tinha o seguinte significado prático:

“[Reduzir] o automatismo do padrão-ouro a uma mera aparência. Ela [a atuação do banco central] implicava uma moeda administrada de forma centralizada; o mecanismo auto-regulado de oferta de crédito era substituído pela manipulação, ainda que esse artifício não fosse sempre deliberado e consciente. Cada vez mais se reconhecia que o padrão-ouro internacional só poderia funcionar de modo autoregulado às custas da eliminação do banco central. O defensor consistente do padrão- ouro puro que realmente advogava essa medida desesperada era Ludwig von Mises; seu conselho, se tivesse sido seguido, teria transformado as economias nacionais num monte de ruínas". 108

Polanyi credita ao antimercantilismo ${ }^{109}$, até então em voga, os equívocos da teoria monetária liberal: a separação entre política e economia, a concepção da moeda como um categoria exclusivamente econômica. ${ }^{110}$ Sua crítica volta-se especificamente para o

\footnotetext{
${ }^{105}$ Ibid.

${ }^{106}$ Ibid., p. 202.

${ }^{107}$ Ibid., p. 203.

${ }^{108}$ Ibid., p. 204. Na edição brasileira, o argumento foi invertido por um erro de tradução: "O Banco Central reduziu o automatismo do padrão-ouro a uma mera pretensão. Ele significava uma direção central para o meio circulante e a substituição da manipulação pelo mecanismo auto-regulador do fornecimento do crédito..." (A grande transformação: as origens da nossa época, 2a. ed., Rio de Janeiro: Campus, 2000, pp. 231-232, grifos meus). O equívoco vem certamente do fato de que, em inglês, o verbo "to substitute" é usado de forma invertida: "[...] manipulation was substituted for the self-regulating mechanism of supplying credit [...]". Obviamente, não seria necessário o cotejamento com o original em inglês para perceber o equívoco, já que, no contexto da argumentação de Polanyi, da forma que foi traduzida, a frase não faz o menor sentido.

${ }^{109}$ Não é Polanyi quem utiliza a expressão "antimercantilismo", mas José Luís Fiori ("Estados, moedas e desenvolvimento", in José Luís Fiori (org.), Estados e moedas no desenvolvimento das nações, Petrópolis, RJ: Vozes, 1999, pp. 49-85.

${ }^{110}$ Cf. Karl Polanyi, The great transformation, ob. cit., p. 204.
} 
conceito ricardiano de moeda, meramente técnico e politicamente neutro. Para Ricardo e os demais economistas clássicos, a moeda não passava de mais uma mercadoria. ${ }^{111}$

Uma evidência do caráter político da criação do banco central foi o seu apoio pelas classes dirigentes. Embora estas considerassem a atuação de um banco central compatível com o funcionamento do padrão-ouro, era óbvio que as regras deste último não prevaleceriam, por exemplo, se eventualmente a taxa de deflação necessária para manter a estabilidade do câmbio desse um salto abrupto, configurando uma variação insuportável para a sociedade: ${ }^{12}$

"O fato de as moedas serem administradas tornou-se importantíssimo, pois significava que os métodos do banco central eram matéria de política pública (policy), quer dizer, algo sobre o que o corpo político poderia deliberar. Realmente o grande significado institucional da atuação do banco central residiu no fato de que a política monetária foi portanto atraída para a esfera da política (politics)."

O segundo paradoxo apontado por Polanyi é a conseqüência externa da politização das moedas nacionais mediante a atuação do banco central. Em meio à retórica predominante do livre comércio, o protecionismo e o imperialismo ganhavam terreno. Funcionando como um anteparo entre a economia externa e a interna, o banco central permitiu aos países a permanência no "padrão-ouro" sem que se expusessem aos seus efeitos destruidores, mas serviu também para criar as bases de um novo nacionalismo. ${ }^{114}$

O duplo movimento que caracterizou a ascensão e queda do padrão-ouro, culminando com o aumento da intervenção estatal por meio do banco central, é, segundo Polanyi, o que de forma mais dramática e abrupta expressa o colapso da economia de mercado: "o fracasso final do padrão-ouro foi o fracasso final da economia de mercado". 115 Enquanto o protecionismo ligado à terra (tarifas agrícolas) e ao trabalho (a legislação social) estava relacionado a estratos sociais amplos, mas delimitados, o "protecionismo

${ }^{111}$ Ibid., p. 205.

${ }^{112}$ Ibid., p. 206.

${ }^{113}$ Ibid., pp. 206-207.

${ }^{114}$ Ibid., pp. 207-208.

${ }^{115}$ Ibid., p. 209. 
monetário" tinha uma dimensão nacional. O sistema monetário era "a mais forte dentre as forças econômicas a promover a integração da nação": ${ }^{116}$

"O que o homem de negócios, o trabalhador organizado e a dona-de-casa ponderavam, sobre o que o fazendeiro que estava planejando sua safra, os pais que estavam avaliando as oportunidades de seus filhos e os amantes que estavam esperando para se casar refletiam, ao avaliar as perspectivas de vida da época, era mais diretamente condicionado pela política monetária do banco central do que por qualquer outro fator. [...] Politicamente, a identidade da nação era estabelecida pelo governo; economicamente dela estava investida o banco central." ${ }^{117}$

A análise que Polanyi faz do dinheiro e do crédito não desce aos detalhes da regulação financeira, e nem era seu objetivo fazê-lo. Sua relevância consiste em demonstrar o caráter peculiar do dinheiro: mercadoria fictícia, ele é necessariamente objeto da regulação estatal na sociedade complexa e mundializada, sob pena de se comprometer a coesão social.

A análise institucional do dinheiro revela o caráter indispensável e sui generis da regulação financeira. A distinção entre, de um lado, a regulação dos serviços públicos e das atividades econômicas não financeiras (como a produção de petróleo, no Brasil) e, de outro, a regulação do mercado financeiro, pode assim ser vista sobre bases mais amplas do que as fornecidas por Llewellyn e a literatura pró-regulação. Mais do que uma rationale econômica para a regulação financeira, ou do que vagas afirmações relativas ao interesse público subjacente, a regulação do crédito e do dinheiro - e conseqüentemente de todos os agentes e instituições em torno deles organizados - é fundamental para não permitir que os "moinhos satânicos" do mercado triturem a vida dos indivíduos e do setor produtivo. Mais que isso, ela é fundamental para a preservação do tecido social.

Não obstante a clarividência da análise de Polanyi, ${ }^{118}$ o dinheiro ainda continua sendo analisado pela ciência econômica mais prestigiosa como se ele não estivesse

\footnotetext{
${ }^{116}$ Ibid., p. 213.

117 Ibid., p. 214.

${ }^{118}$ Para uma avaliação da atualidade do pensamento de Polanyi e sua relevância para a reflexão sobre a economia internacional, ver o prefácio de Joseph Stiglitz à segunda edição de The great transformation (ob. cit., pp. vii - xvii) e a "Introdução" à mesma edição, escrita por Fred Block (pp. xviii-xxxviiii). Para uma análise bem mais sofisticada, ver José Luís Fiori, “Estados, moedas e desenvolvimento’, ob. cit.
} 
submerso na vida social. Na perspectiva neoclássica, segundo a síntese de Robert Guttmann, ${ }^{119}$ a moeda é mero instrumento técnico que facilita as trocas e a acumulação de riqueza. Trata-se de uma visão meramente funcional, que preserva a coerência da ortodoxia neoclássica em relação às suas premissas: ${ }^{120}$ (a) o homo oeconomicus, que toma decisões de forma racional, comparando custos e benefícios marginais; (b) uma visão do mercado como extensão destas regras de otimização microeconômicas, que levam a um equilíbrio expressado pela intersecção das curvas de oferta e de demanda; (c) o modelo de “equilíbrio geral” de Leon Walras; (d) a possibilidade de substituição dos fatores de produção, a clarividência [perfect foresight] dos agentes econômicos e preços livres no mercado de recursos; (e) ao nível macroeconômico, a adoção destas premissas para mostrar a tendência automática da economia para o pleno emprego, no equilíbrio entre demanda e oferta agregadas.

Como argumenta Guttmann, para que a existência da moeda não perturbe as condições de equilíbrio, o pensamento neoclássico é obrigado a concebê-la como um bem. Assim, do lado da oferta, ela é vista como um estoque controlado de forma exógena pelo banco central. Do lado da demanda, é um ativo que garante liquidez a seus portadores. Ao lado da economia "real" da produção e das trocas desenvolve-se a esfera "monetária", que a complementa, sem distorcer suas condições de equilíbrio. É a teoria quantitativa da moeda que articula as duas esferas. Essa perspectiva faz com que a regulação financeira deixe de ser visualizada em toda sua complexidade.

Na tradição intelectual da Escola Francesa da Regulação ${ }^{121}$ podemos encontrar uma análise que reforça (i) a tese de que a moeda não é uma mera mercadoria e (ii) a sua importância para a coesão social. ${ }^{122}$ A moeda é explicada como um dos componentes do

\footnotetext{
${ }^{119}$ Robert Guttmann, How credit-money shapes the economy: the United States in a global economy, New York: M. E. Sharpe, 1994, pp. 16-17.

${ }^{120}$ Sigo, aqui, de perto, Robert Guttmann, How credit-money shapes the economy, ob. cit., pp. 10-11.

${ }^{121}$ Robert Boyer, em recente balanço da teoria da regulação, ressalta a unidade metodológica de seus vários teóricos, apontando os quatro pilares da teoria: (i) interdisciplinaridade; (ii) uma generalidade que decorre não de uma derivação axiomática, mas de uma progressiva generalização de suas noções de base, construída ao longo de mais de trinta anos de pesquisas; (iii) a historicidade das regulações e dos modos de desenvolvimento; (iv) a ambição de explicar, com o mesmo conjunto de hipóteses, o maior número possível de fatos estilizados, dos anos cinqüenta ao início do século XXI (“Avant-propos à la seconde édition", in: Robert Boyer et Yves Saillard (dir.), Théorie de la régulation: l'état des savoirs, nouvelle édition complétée, Paris: La Découverte, 2002, pp. 10-12).

${ }^{122} \mathrm{O}$ problema da coesão não se limita à análise da moeda. Ele está presente em toda regulação: “Il n'y a reproduction que du problème de la socialisation: comment une cohésion sociale peut-elle exister dans le
} 
quadro institucional que mantém o equilíbrio necessário para a reprodução estável de um sistema econômico. Ela é, portanto, uma das formas institucionais que definem um regime de acumulação, o que pressupõe uma concepção alargada da endogeneidade da moeda: a forma como ocorre sua criação e circulação contribui para determinar um modelo de crescimento de uma economia. A configuração institucional específica, ou seja, um regime monetário ao qual corresponde um regime de acumulação, é composto pela gestão da criação de moeda pelo banco central (política monetária), pela regulamentação do setor bancário (política financeira), pelos mecanismos de empréstimo de última instância para a contenção de crises financeiras, e pelas regras de transferência financeiras entre países. ${ }^{123}$

A sofisticada e elegante teoria monetária de Aglietta e Orléan tenta demonstrar que o fenômeno monetário, "expressão da comunidade como um todo", possui uma ambivalência intrínseca: por um lado, medium de coesão e de pacificação, por outro, fonte de poder e de violência. ${ }^{124}$ Também para eles, portanto, como para Polanyi e Guttmann, não se pode conceber a moeda simplesmente como um instrumento que facilita as trocas. Para comprovar essa tese, eles desenvolvem um quadro teórico composto por dois elementos: a "hipótese mimética" e a teoria da confiança. ${ }^{125} \mathrm{O}$ ponto de partida de sua análise é a "hipótese monetária": toda relação no mercado, mesmo na sua forma mais elementar, pressupõe a existência prévia da moeda. Esta não é, porém, algo estático ou consolidado: “aucune monnaie n'est definitivement instituée”. Devido à hipótese da concorrência entre moedas, a relação monetária é sempre um devenir. A moeda nunca tem sua legitimidade garantida. Sua realidade é dinâmica: “elle n'est rien d'autre que le nom qu’on donne à la règle du jeu social que jouent les acteurs économiques.“ ‘26

A originalidade de sua teoria reside no caráter convencional que ela atribui à riqueza: "a riqueza é o que é desejado por todos os membros do grupo". Com base nos

déchirement des conflits? C'est ce problem que la notion de régulation tente d'assumer" (Michel Aglietta, Régulation et crises du capitalisme, nouvelle édition revue et corrigée, Paris: Odile Jacob, 1997, p. 13).

${ }^{123}$ Cf. Robert Guttmann, "Monnaie et crédit dans la théorie de la régulation", in: Robert Boyer et Yves Saillard, Théorie de la régulation: l'état des savoirs, ob. cit., pp. 85-93.

${ }_{124}$ Michel Aglietta et André Orléan, La monnaie entre violence et confiance, Paris: Odile Jacob, 2002.

${ }^{125}$ Agllietta e Orléan ressaltam que o novo livro não é uma reedição nem uma mera atualização de $L a$ violence de la monnaie, de 1982, no qual o mimetismo monetário e financeiro já estava desenvolvido. Tratase de livro novo, no qual a hipótese mimética aparece desenvolvida com as idéias de confiança e de soberania (Ibid., pp. 7-9).

${ }^{126}$ Ibid., pp. 35-37. 
trabalhos de René Girard, ${ }^{127}$ Aglietta e Orléan desenvolvem a formalização do modelo teórico que busca demonstrar o caráter racional do mimetismo que dá origem à moeda. Essa demonstração é necessária na medida em que o comportamento de imitação é tido como irracional pela ciência econômica convencional.

Em sua busca por riqueza, os indivíduos dão início a um processo de mimetismo que leva a uma polarização unânime, ou seja, à focalização de todos os desejos de riqueza em um único bem. Este bem, até então uma forma privada e provisória de riqueza, adquire uma legitimidade social. É esse processo de "eleição-exclusão" que está na base da origem da moeda. Com suas propriedades estabilizadas pela polarização mimética, a moeda tornase uma instituição que conforma o mercado - esse é o ponto de encontro entre a hipótese mimética e a hipótese monetária. ${ }^{128}$

O segundo movimento de Aglietta e Orléan, além da formalização teórica do mimetismo, é a busca de uma fundamentação empírica para suas hipóteses. Assim como Polanyi - que é diversas vezes referido -, eles apóiam-se na antropologia e na história. ${ }^{129}$ A análise que Marcel Mauss faz dos Maoris demonstra a indistinção, ou mesmo a fusão de coisas e indivíduos que caracteriza as trocas nas sociedades arcaicas:

"Il est net qu'en droit maori, le lien de droit, lien par les choses, est un lien d'âmes, car la chose elle-même a une âme, est de l'âme. D'ou il suit que présenter quelque chose à quelqu'un, c'est présenter quelque chose de soi [...]”. ${ }^{130}$

As trocas configuravam, nos termos de Mauss, um "fato social total" - nelas, a totalidade da sociedade e de suas instituições se fazia presente, o que demonstra, para Aglietta e Orléan, como a economia estava submersa na sociedade - aqui uma referência direta a Polanyi. ${ }^{131}$

\footnotetext{
${ }^{127}$ São os seguintes os trabalhos citados de René Girard: Mensonge romantique et vérité romanesque, Paris: Grasset, 1961; La violence et le sacré, Paris, Grasset, 1972; e Des choses cachées depuis la fondation du monde, Paris, Grasset, 1978.

${ }_{128}$ Michel Aglietta et André Orléan, La monnaie entre violence et confiance, ob. cit., pp. 38-39.

${ }^{129}$ A principal referência deles é o trabalho de Marcel Mauss sobre as trocas nas sociedades arcaicas ("Essai sur le don. Forme et raison de l'échange dans les sociétés archaïques", in: L'Année sociologique, seconde série, 1, 1923-1924, reproduit in Sociologie et Abthropologie, Paris: PUF, 1983, pp. 143-279).

${ }^{130}$ Cf. Marcel Mauss, ob. cit., pp. 160-161, apud Michel Aglietta et André Orléan, ob. cit., p. 40.

${ }^{131}$ Michel Aglietta et André Orléan, ob. cit., p. 41.
} 
Outra característica fundamental das sociedades arcaicas é relativa à dívida. No holismo que as caracteriza, o homem já nasce endividado. Ele tem dívidas para com sua família, sua comunidade e para com os deuses. É essa "dívida primordial" 132 que dá sentido à vida, na medida em que ela expressa sua pertença à sociedade. Ela nunca é paga, e nem deveria, pois a sua continuidade representa a manutenção dos valores da comunidade e a reprodução das suas condições de existência. Os deveres decorrentes dessa dívida - perante os deuses, os ancestrais e o Veda - definem o que é uma vida correta, uma "vida boa". 133

O surgimento das relações mercantis rompe com esses padrões holistas. O econômico emerge das relações sociais. Cria-se entre os indivíduos uma separação: os laços pessoais de reciprocidade, dependência e hierarquia cedem lugar a um mundo de mercadorias e de dívidas voluntárias. No lugar da "dívida primordial", constitui-se a "dívida econômica". ${ }^{134}$ Destacada dos indivíduos que a negociam, a mercadoria torna-se um objeto anônimo, livremente transferível, que visa simplesmente a satisfazer necessidades: não ostenta mais qualquer traço das relações sociais que ela expressava, mas tão somente utilidade. Completada a compra e venda, nenhuma obrigação mais permanece: a dívida assume uma dimensão exclusivamente privada. ${ }^{135}$

Essa transformação ocorre mediante a supressão de direitos e de costumes - um processo violento, que tem nas enclosures da Inglaterra um de seus mais famosos exemplos. Não obstante sua gênese violenta, as relações mercantis têm apresentado um "incrível poder de expansão". Sua legitimidade e supremacia perante as demais relações sociais deriva da relação entre economia mercantil e os valores individualistas. Com a ideologia individualista, a primazia da relação dos homens com os objetos sobre a relação dos homens entre si exerce um fascínio que deve obrigatoriamente ser levado em conta para a compreensão da ambivalência (coesão/violência) do fenômeno monetário moderno. A separação do indivíduo em relação ao outro é acompanhada pela transição da "dívida

\footnotetext{
${ }^{132}$ Sobre a "dívida primordial", a referência é o trabalho de Charles Malamoud sobre a Índia védica ("Croyance, finance, confiance dans l'Inde ancienne", Revue d'économie financière, numéro spécial hors série, novembre 1991, p. 590).

${ }^{133}$ Michel Aglietta et André Orléan, ob. cit., pp. 52-53.

${ }_{134}^{134} \mathrm{Ibid}$., p. 53.

${ }^{135}$ Ibid., p. 43.
} 
primordial" para a "dívida econômica", um processo no qual a moeda tem um papel fundamental: é por meio dela que o indivíduo mercantil se libertará de suas dívidas. ${ }^{136}$

O papel da moeda, entretanto, em muito transcende a mera função de pagamento da dívida econômica. Ela vai ser responsável por trazer o que a relação mercantil separou: “c'est la monnaie qui donne vie sociale à la séparation marchande et c'est dans ce rôle qu'elle trouve son fondement ultime". ${ }^{137}$ A opacidade que a separação cria para as relações individuais é causa de uma incerteza que, somada à imprevisibilidade de eventos exógenos (o risco) e aos ditames da escassez, provoca uma busca por segurança. ${ }^{138}$ Essa busca por proteção manifesta-se como desejo por um objeto, o que Aglietta e Orléan vão chamar de riqueza. Como já referido supra, ela tem para eles um caráter convencional.

Considere-se uma situação elementar em que dois indivíduos mercantis encontramse face-a-face, caracterizada pela indefinição de um princípio monetário legítimo $(\mathrm{F} 1){ }^{139}$ Em tal situação, um indivíduo não tem a certeza de que a moeda que ele recebeu do outro será posteriormente aceita por um terceiro. Nessas condições, fica muito difícil uma forma estável de troca. Em busca de acumulação de riqueza - concretamente, em busca do bem com maior grau de liquidez —, os indivíduos vêem-se envolvidos numa situação indefinida, na medida em que reina a confusão entre mercadorias e moeda: "chercher la richesse, c'est chercher ce qui est désiré par tous, c'est chercher le désirable absolu" ${ }^{140} \mathrm{Se}$ a riqueza não depende de sua forma concreta, como então "descobrir" o objeto cuja acumulação conduz à riqueza, se o outro encontra-se separado, se a opacidade é uma decorrência do individualismo?

É nesse ponto que a hipótese mimética, explicada supra, aparece. A natureza intersubjetiva da riqueza faz com que em F1, a "situação mercantil originária", o mimetismo seja um comportamento fundamental. Todos buscam, na observação e imitação do comportamento alheio, identificar, dentre algumas mercadorias, aquela que será a moeda. Diversos bens disputam esse papel. É uma situação de fracionamento (fractionnement) generalizado. Um exemplo bastante conhecido de F1 foi a hiperinflação

\footnotetext{
${ }^{136}$ Ibid., pp. 48-53.

${ }^{137}$ Ibid., p. 59.

${ }^{138}$ Ibid., pp. 59-66.

139 A denominação "F1", assim como a posterior "F3", é feita em referência a Marx.

${ }^{140}$ Michel Aglietta et André Orléan, La monnaie entre violence et confiance, ob. cit., pp. 70-74.
} 
alemã. De fato, os momentos de profunda crise monetária caracterizam-se por essa incerteza. ${ }^{141}$ Em meio à confusão, há uma luta de todos contra todos, uma disputa pela definição da riqueza, razão pela qual F1 é caracterizada por uma "violência essencial".

Essa "violência essencial" poderia levar à violência física e, no limite, à destruição da sociedade. A hipótese de Aglietta e Orléan, entretanto, na esteira de René Girard - o "teorema girardiano fundamental" -, é de que F1 possui uma dinâmica aleatória que converge para a unanimidade do grupo. Uma vez que se chega a um entendimento generalizado sobre o objeto que representa a riqueza - uma mercadoria que se transforma em moeda -, a "violência essencial" cede lugar à "violência fundadora" (F3). A moeda revela-se, ao final de um processo endógeno, como a forma socialmente reconhecida de riqueza. ${ }^{142}$

F3 tende a se auto-reproduzir. O objeto eleito como símbolo da riqueza é excluído das disputas que caracterizavam F1, adquirindo legitimidade. É essa seqüência de eleiçãoexclusão que forma o núcleo da teoria monetária de Aglietta e Orléan. ${ }^{143}$ Essa legitimidade, entretanto, não é definitiva. A todo momento a moeda é desafiada a prová-la. Em F1, a concorrência dá-se de forma generalizada entre todos os bens, já que não havia moeda. Saindo da argumentação lógica para a evolução concreta das economias mercantis, o que se verifica é uma concorrência entre moedas (F2). Nos termos de Aglietta e Orléan, uma concorrência mimética entre "moedas parciais", situação que eles denominam de "violência recíproca". A concorrência entre moedas reforça a idéia de que a moeda não é uma mercadoria. Enquanto nas formas clássicas de concorrência, o aumento pela demanda de um bem leva ao aumento de seu preço e, conseqüentemente, à diminuição da demanda, com a moeda ocorre exatamente o contrário. Quanto mais ela se consolida como "a" moeda, com o aumento de sua demanda, mais demandada ela será. ${ }^{144}$ A violência que dá origem à moeda traz consigo a confiança desejada pelos indivíduos mercantis, eliminando a incerteza que perturbava suas relações. Violência e confiança constituem, para usar um trocadilho, as duas faces da mesma moeda.

\footnotetext{
${ }^{141}$ Ibid., p. 79.

${ }^{142}$ Ibid., pp. 77-84.

${ }^{143}$ Ibid., p. 84.

${ }^{144}$ Ibid., pp. 87-89.
} 
Essa teoria monetária tem profundas implicações para a justificação da regulação financeira. Se, por um lado, a polarização unânime que dá sustentação à moeda gera a confiança que promete o funcionamento harmônico do mercado, por outro, a moeda é fonte do desejo por dinheiro, elemento que provoca as crises que desorganizam a economia. Essa contradição, que se aguça com a expansão mundial do capitalismo, exige a regulação da moeda pelo poder público para a preservação da confiança: ${ }^{145}$

\footnotetext{
"On saisit donc que le double aspect de la monnaie, à la fois rapport collectif et objet d'appropriation privée, rend radicalment impossible une autorégulation de la monnaie par les échanges marchands. Lorsqu'on a compris que la monnaie est l'operateur de la valeur économique, non pas un objet particulier dont l'échange conférerait une valeur, on a aussi compris que la monnaie requiert une régulation sociale." ${ }^{146}$
}

Diante da necessidade de justificar a regulação financeira, a literatura costuma trazer a seguinte indagação: por que os bancos são especiais? Já vimos, com Llewellyn, a resposta convencional. Vimos, porém, que uma análise mais ampla do fenômeno monetário não somente reforça a rationale econômica para a regulação, como lhe fornece uma justificativa muito mais profunda: a manutenção da coesão social. Se a moeda, na sua ambivalência, é algo especial para a sociedade, os bancos, enquanto agentes econômicos que com ela mantêm uma relação privilegiada, devem ser fortemente regulados. Mais regulados do que os próprios serviços públicos.

De fato, se levamos a sério a especificidade da função dos bancos, que é, em última instância, a criação de moeda, torna-se impensável conceber que eles possam funcionar mediante uma auto-regulação temperada pela lei antitruste, pela legislação de defesa do consumidor e pela atuação compensatória ex post do Judiciário. Como resume Aglietta, “a criação monetária é um ato duplo e indissolúvel por meio do qual a decisão de emprestar não é a transferência de um depósito pré-existente, mas sim a formação de um novo depósito". E complementa, citando Rachline: "os créditos constituem os depósitos" (grifei). ${ }^{147}$

\footnotetext{
${ }^{145}$ Ibid., p. 103.

${ }^{146}$ Ibid., p. 153.

${ }^{147}$ Cf. Michel Aglietta, Macroéconomie financière, vol. 1, 3e. ed., Paris: La Découverte, 2001, p. 70.
} 
Essa verdade básica da criação de moeda mostra porque os bancos são indispensáveis para o financiamento do consumo e do investimento produtivo público e privado. Eles são fornecedores de liquidez em grande quantidade e no momento em que ela é demandada, sem que esta liquidez esteja condicionada à poupança prévia. Na evolução histórica dos sistemas bancários, o Estado assumiu, por meio do banco central, o papel de garantidor final dos depósitos. O acesso dos bancos aos fundos do banco central assistência de liquidez — reforça a justificativa da sua regulação e supervisão por agências estatais. $^{148}$

A regulação financeira restringe a liberdade contratual e o direito de propriedade dos bancos naquilo que é o seu principal negócio: quanto e para quem emprestar dinheiro.

Esse regime jurídico híbrido - meio atividade econômica, meio serviço público ao qual os bancos se submetem na sociedade contemporânea é claramente um reflexo da ambivalência da moeda: de um lado, instituição que permite as trocas econômicas e garante a coesão social, de outro, objeto que permite a acumulação privada de riqueza.

Embora os bancos estejam no centro das atenções - principalmente das preocupações de caráter sistêmico -, o caráter central da moeda numa sociedade complexa contamina, por assim dizer, as demais atividades financeiras não bancárias. As razões para isso são basicamente aquelas mesmas referidas supra, no início desse subcapítulo, que desafiam a estrutura regulatória atualmente existente em diversos países: o surgimento de conglomerados financeiros, a inovação financeira, a complexidade crescente da atividade bancária, a obsolescência dos critérios convencionais de distinção entre tipos de firmas financeiras, e a internacionalização das finanças.

A revogação, cinco anos atrás, do Glass-Steagal Act e, antes disso, a mudança regulatória operada pelos próprios reguladores ao longo de duas décadas, ${ }^{149}$ demonstram a

\footnotetext{
${ }^{148}$ Ibid., pp. 71-73.

149 Promulgado em 1933, no rastro da crise bancária que levou à quebra de cerca de nove mil bancos, durante a Grande Depressão, , o Glass-Steagall Act criou uma separação entre as atividades dos bancos comerciais e o setor de valores mobiliários. A reforma regulatória da década de trinta tornou o mercado financeiro dos E.U.A. altamente regulamentado. Somente em 1999, o Gramm-Leach-Bliley Act extinguiu as barreiras que moldaram durante mais de seis décadas a dinâmica do sistema financeiro norte-americano. A mudança institucional é o resultado visível de uma mudança no processo real econômico, o que já era reconhecido e referendado pelo Federal Reserve, o banco central dos E.U.A.: o importante caso da fusão Citicorp/Travelers, aprovada pelo FED em 1998 - portanto, anteriormente à nova lei --, foi o ponto culminante da mudança da estrutura regulatória levada a cabo pelo próprio FED. Ver Helen A. Garten, US financial regulation and the level playing field, New York: Palgrave, 2001, especialmente pp. 91 ss. O papel
} 
precariedade da distinção entre atividade bancária, de seguros e de valores mobiliários, para fins de regulação. Não somente os bancos não vão desaparecer - dada a indispensabilidade de seu papel de market maker -, como eles estarão cada vez mais atuantes em setores nos quais até pouco tempo eles não podiam atuar. Na União Européia, como lembra Aglietta, existe a possibilidade de se desenvolver um modelo financeiro que leve a um mercado único de serviços financeiros, caso se aprofunde a aliança entre bancos e companhias de seguro que se esboça na França e na Alemanha. ${ }^{150}$ Os países nos quais a atuação bancária já há muito tempo não tem restrições já sentem há mais tempo a necessidade de reformular as instituições e os procedimentos da regulação financeira.

Qualquer que seja a nova racionalidade da nova regulação financeira, qualquer que seja sua configuração institucional, e qualquer que seja o sistema financeiro no qual ela esteja inserida, ela continuará exercendo um papel central na vida social. Continuará requerendo técnicos altamente qualificados e um orçamento considerável. Além disso - o que mais nos interessa no presente trabalho - os órgãos estatais dela incumbidos continuarão tendo uma amplíssima capacidade normativa de conjuntura.

Esse poder normativo que instrumentaliza a regulação financeira é o objeto do presente trabalho. Não importam aqui, portanto, os detalhes do conteúdo da regulação por exemplo, a forma como ela incorpora, no Brasil, as novas regras da Basiléia. O que está sendo analisado é, para usar o termo clássico de Hart, ${ }^{151}$ a regra secundária que confere ao regulador - ou aos reguladores - dos mercados financeiros a competência para inovar a ordem jurídica e restringir a liberdade e a propriedade dos agentes privados. Essa reflexão é válida, portanto, para todos os serviços financeiros. Ela subsiste, insista-se, independentemente da repartição de competências presente e futura.

Somente uma teoria crítica da moeda e do mercado financeiro - ou, em termos mais amplos, uma teoria crítica do econômico - pode informar uma análise do direito que também se pretenda crítica, quando ela se debruça sobre a regulação financeira. Seria irônico se essa análise, ao rechaçar os limites estreitos de uma teoria pura do direito,

dos reguladores do mercado financeiro nos E.U.A. foi enfatizado em recente trabalho de Jonathan Macey: "In other words, the Glass-Steagall Act was already a dead letter when Gramm-Leach-Bliley was passed" ("The business of banking: before and after Gramm-Leach-Bliley Act", Journal of Corporation Law 25 (2000), pp. 691-722).

${ }^{150}$ Ibid., pp. 89-91.

${ }^{151}$ The Concept of Law, 2nd. ed., London: Oxford University Press, 1997, p. 31. 
precisasse adotar, na sua empreitada interdisciplinar, as premissas igualmente estreitas de uma teoria pura da economia.

\section{O déficit democrático da regulação financeira}

Tal como os órgãos - atuais "agências" - reguladores dos serviços públicos, os reguladores financeiros promovem uma regulação no sentido mais amplo desse termo: eles praticam atos administrativos, criam direito, incumbem-se de sua interpretação e aplicação - ou seja, julgam. Além disso, não somente implementam, como formulam políticas públicas, desempenhando, portanto, as três funções clássicas do Estado. Juntamente com o banco central, eles parecem compor um "quarto poder" -- expressão recorrente na literatura sobre as agências reguladoras. Há trabalhos que chegam inclusive a comparar os bancos centrais com os tribunais constitucionais. ${ }^{152}$

Como visto na parte inicial do presente capítulo, a atribuição de tais competências a órgãos que não contam com a legitimidade das urnas é considerada uma anomalia perante o direito constitucional. Para outros, é vista como um elemento necessário do desenho institucional do Estado Regulador contemporâneo. Esse é o ponto onde o debate sobre o processo de burocratização da vida social encontra a reflexão sobre o desenvolvimento do direito público ocidental, especificamente a questão da separação dos poderes. Nesse contexto, o exemplo mais impressionante da expressão jurídica da tecnocracia é a cláusula do Tratado de Maastricht que confere autonomia ao banco central europeu. Além disso, ganham cada vez mais importância na União Européia os estudos de "comitologia", ou seja, o estudo dos comitês - a burocracia que regula cada detalhe da vida dos cidadãos europeus. $^{153}$

\footnotetext{
${ }^{152}$ Ver Jon Elster, "Constitutional courts and central banks: suicide prevention or suicide pact?", East European Constituional Review (1994), pp. 66-71; Charles Goodhart, "The constitutional position of an independent central bank", Government and opposition 37 (2002), pp. 190-210.

${ }^{153}$ Ver Christian Joerges, "Bureaucratic nightmare, technocratic regime and the dream of good transnational governance", in Christian Joerges/Ellen Vos (ed.), EU committees: social regulation, law and politics, Oxford: Hart Publishing, 1999, pp. 3-17.
} 
É bastante conhecida a caracterização que Max Weber fez do fenômeno burocrático moderno (distinto das burocracias antigas). ${ }^{154}$ Para ele, a organização burocrática do Estado e das empresas modernas tem competências hierarquizadas determinadas por leis e regulamentos, um corpo de funcionários profissionais (cujo recrutamento e promoção na carreira dão-se segundo o mérito). As funções não se confundem com os homens, o que garante a força impessoal das organizações públicas e privadas. Trata-se, como se sabe, de mais um tipo ideal de Weber. ${ }^{155}$ A burocracia, aqui, é pensada não como um tipo de governo, mas sim como um sistema de administração, e a burocratização, processo conexo ao de racionalização, desenvolvido em meio a uma luta entre inovação carismática e racionalização burocrática. ${ }^{156}$ Embora a experiência alemã fosse sua referência empírica mais importante, aquele processo seria uma característica universal da sociedade moderna. $^{157}$

Weber constatou a superioridade das modernas técnicas da organização burocrática em relação às formas tradicionais de organização social, o que indicava que as sociedades industriais avançadas não poderiam mais abrir mão daquelas técnicas.

Entretanto, mais do que a eficiência, foram as conseqüências políticas da expansão do poder burocrático que preocuparam Weber. ${ }^{158}$ Para ele, há uma antinomia insolúvel: ao mesmo tempo em que a moderna burocracia traz eficiência, ela pode minar a sociedade liberal, destruindo as próprias premissas sociais das quais depende a conduta individual. Um dos perigos reside na tendência apresentada pela burocracia de inibir o surgimento de novas lideranças. Daí a necessidade do desenvolvimento de instituições que viabilizem o aparecimento de líderes - a democracia plebiscitária evitaria o crescimento exagerado da burocracia. O outro perigo consistiria na propagação de valores instrumentais na sociedade.

\footnotetext{
${ }^{154}$ Ver Max Weber, "Burocracia", in C. Wright Mills and Hans Gerth (org.), Max Weber: Ensaios de Sociologia, trad. Waltensir Dutra, Rio de Janeiro, Guanabara Koogan 1982, pp. 229-282.

${ }^{155}$ Ver Wolfgang Mommsen, "Max Weber on bureaucracy and bureaucratization: threat to liberty and instrument of creative action", in The political and social theory of Max Weber, Chicago, The University of Chicago Press, 1989, pp. 109-120.

${ }^{156}$ Ver Wolfgang Mommsen, The age of bureaucracy, London, Harper \& Row, 1974, especialmente o capítulo V: “A liberal in despair", pp. 95-115.

${ }^{157}$ Cf. David Beetham Bureaucracy, 2nd ed., Minneapolis, University of Minnesota Press, 1996, p. 52.

${ }^{158}$ Ver David Beetham, ob. cit., p. 51 e ss.
} 
Este último aspecto é importante para que se entenda a relação entre burocratização e racionalização do direito. Foi a burocracia que estabeleceu as bases da administração de um direito racional, conceitualmente sistematizado.

A racionalização do direito deve ser vista em duas perspectivas: interna e externa. ${ }^{159}$ Do ponto de vista interno, ela foi fruto principalmente do trabalho dos juristas profissionais (dos práticos, na Inglaterra, onde o Direito Romano foi barrado pelo corporativismo dos advogados ingleses; dos teóricos, nas universidades). A difusão da escrita possibilitou o registro dos antecedentes judiciais e a codificação.

Enquanto o trabalho dos juristas contribuiu para a racionalização do direito formal (ponto de vista interno), os processos econômicos e políticos contribuíram para racionalizar o direito material (perspectiva externa). Nesta tensão direito formal/direito material, o processo de burocratização tem exercido papel fundamental, mediante a profissionalização dos operadores do direito e a concretização do valor liberal da impessoalidade do Estado.

Entretanto, o agigantamento das burocracias econômicas no século XX, especialmente das autoridades monetárias ${ }^{160}$, radicaliza essa tensão, exigindo a revisão ou mesmo a revogação de princípios e categorias jurídicas do modelo liberal de direito. Mais que isso: esse crescimento solapa o direito formal, transformando a tensão em subordinação do direito formal ao direito material.

O poder normativo das autoridades monetárias no contexto de uma sociedade democrática contemporânea implica, entretanto, a retomada, em novos termos, do clássico debate sobre o papel da burocracia. Como explica Wolfgang Mommsen, ${ }^{161}$ a teoria

\footnotetext{
${ }^{159}$ Sobre essa dupla perspectiva, ver Julien Freund, "La rationalisation du droit selon Max Weber", Archives de philosophie du Droit, v.31, Paris, Sirey, 1981; Wolfgang Schluchter, The rise of western rationalism, Berkeley, University of California Press, 1979, pp. 83 ss.; José Eduardo Faria, Eficácia jurídica e violência simbólica: o direito como instrumento de transformação social, São Paulo, Edusp, 1988, pp. 71 ss.; Eros Roberto Grau, "Os modelos de direito formal e de direito moderno e a dupla desestruturação do direito", in $O$ direito posto e o direito pressuposto, São Paulo, Malheiros, 1996, pp. 64-82. Ver também, deste mesmo autor, La doppia destrutturazione del diritto, Milano, Unicopli, 1996.

${ }^{160} \mathrm{O}$ processo de criação do Banco Central Europeu, com autonomia formal determinada no próprio Tratado de Maastricht, é a demonstração contemporânea mais impressionante do agigantamento da burocracia econômica.

${ }^{161}$ Cf. Wolfgang Mommsen, The age of bureaucracy: perspectives on the political sociology of Max Weber, Rarper\&Row, New York, 1974.
} 
democrática de Weber só pode ser entendida a partir da sua visão do processo histórico como uma tensão entre a tendência de burocratização da vida social e a inovação carismática. O papel do Parlamento nas sociedades modernas limitar-se-ia ao de um celeiro de líderes que, uma vez no Executivo, contrapor-se-iam aos burocratas. O outro papel do Poder Legislativo seria o de fiscalização das estruturas burocráticas. Assim, o rumo das políticas públicas seria o resultado do embate entre a dinâmicas carismática e burocrática. Não haveria, portanto, na teoria democrática de Weber, papel relevante para o Legislativo nem para o Judiciário. Assim, como o arcabouço teórico desse autor poderia ser útil para pensar o controle de constitucionalidade da burocracia econômica?

A segunda objeção a Weber tem caráter metodológico. Sua filiação ao positivismo, consistente na distinção, por ele tão enfatizada, entre juízo de fato e juízo de valor, tornaria seu pensamento incapaz de qualquer forma de crítica social. Este argumento foi radicalizado por David Trubek ${ }^{162}$, que chegou a sustentar veementemente a inadequação de Weber para a construção de uma análise crítica do direito:

"Not all of you may like the vision of our work as trasformative politics. You may rebel from the idea that the purpose of the Law and Society movement is to help us envision a better future and work to realize our visions. You may feel that a scholarly community should limit its aspirations to the production of objective knowledge as defined by positivism. If you choose in this way to stand with Max Weber, be sure you understand his message in all its fullness: Weber tells you that you can and should choose detachment, but also you must abandon hope." 163

O positivismo impotente de Weber permitia-lhe tão somente desenvolver uma visão trágica ${ }^{164}$ da sociedade moderna, na perspectiva de um "liberal em desespero"165.

\footnotetext{
${ }^{162}$ Cf. David Trubek, "Max Weber's tragic modernism and the study of Law in society”. In: Law \& Society Review, vol. 20. n. 4, 1986, p. 573-598.

${ }^{163}$ Ob cit, p. 598.

${ }^{164}$ Devo ao Prof. Marcos Nobre importantes observações sobre a ausência de um potencial crítico em Weber, bem como para o caráter trágico de sua visão social. É conhecida também a crítica de Habermas, para quem Weber e Marx só concebiam a ação social baseada numa racionalidade instrumental (Theory of Communicative Action, vol. 1, Boston, Massachusetts: Beacon Press, 1984. pp. 243 ss).

${ }^{165}$ A expressão passou a ser usada de forma recorrente para referir Weber, e é o título do último capítulo do livro de Mommsen, ob. cit.
} 
Voltado para a capacidade normativa de conjuntura dos principais reguladores do mercado financeiro brasileiro - o $\mathrm{CMN}$ e o $\mathrm{BCB}$-, o presente trabalho parte da premissa de que a competência normativa desses entes estatais é um componente técnico indispensável do Estado contemporâneo - uma expressão jurídica do processo específico de sofisticação da regulação financeira bem como do processo mais amplo de burocratização da vida social. Diante do déficit democrático da formulação de políticas pela burocracia, pretendo, ao contrário da hipótese weberiana, desenvolver a premissa normativa segundo a qual o controle judicial é necessário para garantir a legitimidade democrática do processo administrativo. Como o cidadão comum não dispõe nem do conhecimento técnico nem dos meios materiais necessários para acompanhar o processo de tomada de decisões, o controle judicial deveria funcionar como um mecanismo de controle democrático da regulação financeira.

No Brasil, como vimos na primeira parte do presente capítulo, a doutrina jurídica predominante, de forte caráter liberal, tem reagido negativamente em relação a esse tema. Os manuais e doutrinadores prestigiosos, que formam nas faculdades os futuros operadores do direito, e que influenciam o Judiciário, insistem que a maior parte das normas emanadas do CMN e do BCB é inconstitucional ou ilegal. De um lado, a Constituição de 1988, seguindo uma suposta tradição do direito público brasileiro, vedaria a delegação de poderes. De outro, o poder regulamentar que aqueles órgãos teriam seria meramente para execução da lei, mas jamais para inovar a ordem jurídica.

Enquanto a capacidade normativa de conjuntura não é reconhecida pela doutrina predominante, o dia-a-dia do mercado financeiro desenvolve-se completamente alheio às querelas jurídicas. As instituições financeiras obedecem às normas do $\mathrm{CMN}$ e do $\mathrm{BCB}$ porque os reconhecem como legítimos reguladores. Esse contraste entre law in books e law in action, entre a doutrina jurídica e a realidade da regulação financeira, é uma característica marcante do atual direito público brasileiro. Alienada em relação à dinâmica dos mercados e de sua regulação, essa doutrina tem bloqueado o debate sobre o controle democrático dos poderes da burocracia, especialmente de seu poder normativo.

A especialização técnica e o caráter sigiloso de certos procedimentos próprios do mercado financeiro colaboram para agravar o problema do déficit democrático. Ao desempenhar suas funções, os burocratas geralmente justificam sua ação referindo-se ao 
interesse público, a ele associando razões técnicas de alta complexidade. Conseqüentemente, somente os iniciados em economia monetária e finanças e os protagonistas do mercado financeiro conseguem acompanhar e exercer algum tipo de controle sobre as decisões tomadas com o grau necessário de conhecimento.

O presente trabalho pretende investigar esse déficit democrático a partir da jurisprudência do Supremo Tribunal Federal (STF). A idéia é verificar se o controle judicial realizado pelo STF tem funcionado como uma forma de controle democrático, definindo os limites para o exercício da capacidade normativa de conjuntura pela burocracia que regula o mercado financeiro.

A visão da moeda como instituição social permite um entendimento mais profundo da regulação financeira. A regulação das atividades bancárias, de seguros e de valores mobiliários pode ser compreendida como peculiar. Dada a importância da moeda e do crédito para a coesão social, a regulação financeira torna-se tão essencial quanto ou mais importante do que a regulação dos serviços públicos. Conseqüentemente, regular ou não regular o mercado financeiro é uma discussão que em muito transcende o debate sobre interesse público e sobre a "captura" das agências reguladoras que tem caracterizado a literatura sobre as public utilities. Não se trata mais de discutir a conveniência da regulação financeira, se ela é -- e por quem ela é -- demandada, se as falhas de governo são maiores do que as falhas de mercado etc. A moeda não é, definitivamente, uma mercadoria como as outras. Mais que isso: a moeda não é uma mercadoria.

O que está em jogo aqui é a coesão social. Retirar a moeda da sua condição de embeddedness, mediante sua desregulamentação, seria recomodificá-la, reduzi-la a um status de mera mercadoria, sujeita às engrenagens erráticas dos "moinhos satânicos" do mercado, como ocorria durante a vigência do padrão-ouro. A regulação financeira revelase, assim, irrenunciável. Pode-se discutir, como é comum na literatura, sua configuração institucional, seu conteúdo prático - por exemplo, sua relação com a lei antitruste - e seus procedimentos. A questão que se põe para as sociedades complexas não é regular ou não regular, mas como regular de forma a conciliar efetividade e democracia. O agigantamento da burocracia reguladora surgiu como uma reação contra as tendências antidemocráticas das forças do mercado. 
Essa mesma burocracia, entretanto, passa ela mesma a representar uma ameaça contra a liberdade e a democracia. Esse é o paradoxo da regulação financeira: ela só nos torna mais livres mediante o alto preço da delegação, para uma tecnocracia altamente especializada, do poder de criar as regras jurídicas que sustentam as instituições sem as quais não podemos sobreviver. É o poder de inovar a ordem jurídica, de restringir direitos, de impor deveres, ônus e obrigações. Um poder que nós imaginávamos só poder ser exercido por nossos legítimos representantes: a classe política que de tempos em tempos elegemos.

É importante relembrar, com essa preocupação em mente, que a institucionalização da moeda dá-se pela violência que gera confiança, um processo que em nada se assemelha ao racionalismo do contrato social:

“À nos yeux, la monnaie n'est nullement instituée dans la transparence et la déliberation rationelle. Elle est le fruit de l'opacité et de la méconaissance. L'espace marchand n'est pas un space public habermassien. Traversé par les rivalités concurrentielles et la lutte pour la survie, il se estructure de manière violente, à l'insu des agents qui n'ont pas la conscience exacte de ce qu'ils vivent." 166

Resta saber se a manutenção da confiança, delegada à burocracia reguladora do mercado financeiro, é permeável aos influxos do espaço público habermasiano - em outras palavras, se é possível, no contexto de uma democracia deliberativa, alguma forma de controle democrático sobre a capacidade normativa de conjuntura mediante a qual o Estado garante, em última instância, a própria coesão social.

Para tanto, faz-se necessária uma reflexão sobre os modelos de democracia e de separação dos poderes que informam a análise que o presente trabalho pretende desenvolver sobre a legitimidade democrática da regulação financeira.

${ }^{166}$ Michel Aglietta et André Orléan, Macroéconomie financière, ob. cit., p. 102. 


\section{CAPÍTULO II}

\section{SEPARAÇÃO DOS PODERES E CONTROLE DEMOCRÁTICO}

1. Da constituição-norma à constituição-máquina: a separação dos poderes como equilíbrio

Considerado um princípio indispensável das constituições democráticas, a separação dos poderes é invocada a todo momento para fundamentar construções doutrinárias e decisões judiciais de grande repercussão política no Brasil. As argumentações que dela se utilizam costumam seguir pelo menos dois caminhos distintos. O primeiro deles leva a uma pretensão de universalidade do princípio, que deve ser concretizado em cada caso, a partir de um núcleo essencial, independente, portanto, do "chão cultural" do direito brasileiro. De acordo com o segundo, adotado pelo Supremo Tribunal Federal (STF), não existiria um princípio universal, inspirado em Montesquieu, mas o princípio tal qual estabelecido pela atual Constituição brasileira - diferente, portanto, dos princípios de outros países. ${ }^{1}$ Ambos os caminhos enfrentam sérias dificuldades no plano dogmático.

No primeiro caso, é comum fazer-se referência a um esquema constitucional ideal, resumido no quadro abaixo, baseado na relação biunívoca entre os elementos do conjunto de órgãos estatais e os do conjunto de funções estatais.

Quadro nº 04: A doutrina jurídica clássica da separação dos poderes

\begin{tabular}{|c|c||}
\hline ÓRG̃̃O & FUNÇÃO ESTATAL \\
\hline Legislativo & Legislativa \\
\hline Executivo & Administrativa \\
\hline Judiciário & Judicial \\
\hline
\end{tabular}

Após o convencional registro da paternidade do princípio, atribuída a Montesquieu - com os sempre citados antecessores Aristóteles e Locke -, costumam ser apontados os

\footnotetext{
${ }^{1}$ ADIn 98-5 - MT (LEX-JSTF 237/24).
} 
“desvios" da realidade, que insistem em não se encaixar naquele modelo tão bem pensado. A explicação, de caráter idealista, tenta demonstrar que "a evolução do Estado e da sociedade" levou o Executivo a assumir parcela da função legislativa, sem que isso caracterize uma afronta à separação dos poderes, já que essa seria apenas uma função atípica do Poder Executivo. A criação de um rol de funções típicas e atípicas para cada órgão de soberania resolveria o problema, preservando o princípio e o caráter "científico" da classificação das funções do Estado.

A dificuldade encontrada por essa doutrina aparece nos casos concretos em que o princípio é aplicado e no conjunto de atribuições de competências de Constituições como a brasileira. Começando por esta última hipótese: a Constituição brasileira de 1988 permite ao Presidente da República editar medidas provisórias, que têm força de lei, e leis delegadas. Considerando-se a quantidade de medidas provisórias editadas desde 1988, torna-se difícil sustentar que a atividade legislativa é uma mera função atípica do Executivo. Mais que isso. Não se trata apenas de quantidade. A importância das matérias por elas tratadas demonstra cabalmente que o Executivo tem substituído o Congresso não somente na tomada de decisões políticas fundamentais, mas no próprio estabelecimento da agenda política do País. Tome-se aqui o exemplo importante do combate à inflação e da instauração de um novo padrão monetário: o Plano Real foi, durante ano e meio, uma medida provisória, com sucessivas reedições.

A aplicação do princípio aos casos que envolvem os temas relacionados à separação dos poderes - como poder regulamentar, delegação legislativa, medidas provisórias, discricionariedade administrativa, mandato dos membros das agências reguladoras, independência do Judiciário, matérias interna corporis do Congresso, dentre outros - só é possível mediante a sua concretização, o que pressupõe um conteúdo mínimo. Se esse conteúdo mínimo é, para essa doutrina, universal, ela entra em choque com entendimento expresso do STF no sentido contrário.

O segundo caminho que se apresenta para a aplicação do princípio é exatamente este seguido pelo Tribunal. Se já não é mais possível recorrer a um núcleo essencial e universal do princípio, seu conteúdo passa a ser definido pelas regras constitucionais de competência e de conduta que lhe dão concreção, como, respectivamente, aquelas que 
tratam das atribuições do Presidente da República ${ }^{2}$ e as que definem como crimes de responsabilidade os atos do Presidente que violem o livre exercício dos demais Poderes e o cumprimento das leis e decisões judiciais. ${ }^{3}$ Chegar-se-ia, assim, ao princípio da separação dos poderes consagrado na Constituição do Brasil, diferente do princípio tal qual ele é estabelecido nas constituições de outros países: $o$ princípio da separação dos poderes $d o$ direito brasileiro.

O STF optou de forma muita clara por essa doutrina quando, em agosto de 1997, decidiu por unanimidade que (i) a vitaliciedade do juiz faz parte do "regime Constitucional brasileiro de separação e independência dos poderes", sendo, portanto, inconstitucional a regra da Constituição do Estado do Mato Grosso que estabelecera a aposentadoria compulsória dos desembargadores após dez anos de Tribunal; (ii) o "autogoverno do judiciário" decorre de sua independência, razão pela qual também são inconstitucionais os artigos da mesma Constituição que criaram um órgão de "controle externo" do Judiciário do Mato Grosso. ${ }^{4}$

Em ambos os casos, foi fundamental o argumento segundo o qual

“O princípio da separação e independência dos Poderes, malgrado constitua um dos signos distintivos fundamentais do Estado de Direito, não possui fórmula universal apriorística: a tripartição das funções estatais, entre três órgãos ou conjuntos diferenciados de órgãos, de um lado, e, tão importante quanto essa divisão funcional básica, o equilíbrio entre os Poderes, mediante o jogo recíproco dos freios e contrapesos, presentes ambos em todas elas, apresentam-se em cada formulação positiva do princípio com distintos caracteres e proporções.",

\footnotetext{
${ }^{2}$ CF 88, art. 84.

${ }^{3} \mathrm{CF} 88$, art. 85, II e VII.

${ }^{4}$ O órgão, denominado "Conselho Estadual de Justiça”, teria a seguinte composição: Presidente do Tribunal de Justiça, Corregedor-Geral da Justiça, um representante da Assembléia Legislativa do Estado, o Presidente da OAB/MT, o Procurador-Geral de Justiça, o Procurador-Geral do Estado, o Procurador-Geral da Defensoria Pública e o Secretário de Justiça. E mais ainda: um juiz de direito, um advogado, um promotor, um defensor público, um procurador do Estado e um serventuário da Justiça, todos estes eleitos pelas respectivas categorias profissionais. Há um precedente: ADIn 135-PB, de 1996, relatada pelo Min. Octavio Gallotti, em que o STF também considerou inconstitucional a criação, pela Constituição da Paraíba, de um órgão semelhante.

${ }^{5}$ Voto do Relator, Min. Sepúlveda Pertence, ADIn 98-5 - MT (LEX-JSTF 237/34).
} 
O princípio impõe, portanto, a observação do "modelo brasileiro vigente de separação e independência dos poderes, como concebido e desenvolvido na Constituição da República”, e não “concepções abstratas ou experiências concretas de outros países". 6

Baseado na regra constitucional expressa que estipula a vitaliciedade, o Tribunal pôde, com relativa facilidade, concretizar o princípio da separação dos poderes. $\mathrm{O}$ problema surge, entretanto, quando do conjunto das regras constitucionais expressas não é possível induzir-se um conteúdo abstrato. Para fundamentar a parte da decisão relativa ao controle externo do Judiciário, o Min. Sepúlveda Pertence foi obrigado a construir um sentido para a separação dos poderes a partir (i) da idéia de "autogoverno" do Judiciário e (ii) da comparação com outros países. Sua conclusão: em alguns países europeus, a criação de conselhos superiores da magistratura teve a intenção de reforçar a independência do Judiciário. O transplante dessas fórmulas para o Brasil teria o efeito oposto. Essa formulação revela claramente o caráter construtivo da interpretação constitucional pelo STF, na ausência de regras expressas. O problema que interpretações como essa suscitam diz respeito à sua consistência. A argumentação racional que poderia sustentá-la deveria ser muito mais sofisticada do que uma mera alusão genérica ao autogoverno do Judiciário.

Verifica-se, assim, uma aporia: o princípio da separação dos poderes não pode ser invocado facilmente para solucionar as antinomias e lacunas relativas às regras da separação dos poderes, pois ele é, por assim dizer, um princípio "vazio" de conteúdo universal e, ao mesmo tempo, essas regras não se prestam a "preencher" adequadamente o princípio, pois não formam um todo completo e coerente.

A solução formal para este importante problema não tem sido enfrentada no direito brasileiro. O arquétipo da divisão rígida de competências, vendido como verdade "científica" na grande maioria dos cursos jurídicos e sustentado pelo argumento de autoridade - Montesquieu -, só contribui para aumentar a confusão.

A compreensão da realidade constitucional contemporânea passa pela desmistificação dessa abordagem - uma simplificação que despreza a riqueza da história da idéia de separação dos poderes. O objetivo do presente trabalho não é reconstituir essa

\footnotetext{
${ }^{6}$ Ibid., p. 36.
} 
história, o que já foi feito em trabalhos especializados. ${ }^{7} \mathrm{O}$ que se pretende aqui é tão somente recuperar, de forma sintética, o que alguns importantes trabalhos - infelizmente pouco conhecidos - já fizeram.

Segundo a síntese proposta por Michel $\operatorname{Troper}^{8}$, a doutrina jurídico-política apresenta a separação dos poderes como um princípio de política constitucional ${ }^{9}$ que comporta duas regras: (a) cada uma das funções do Estado deve ser exercida por uma autoridade especializada; (b) essas autoridades devem ser mutuamente independentes. A aplicação do princípio teria como resultado o equilíbrio mútuo entre essas autoridades nenhuma delas poderia tornar-se despótica. A liberdade seria assim preservada. Esse princípio poderia servir como critério de classificação das constituições (as que o aplicam de forma rígida, as que não o aplicam, e as que o seguem parcialmente).

$\mathrm{Na}$ análise que faz do Capítulo VI do Livro XI do Espírito das Leis, Charles Eisenmann ${ }^{10}$ demonstra, contrariando o senso comum do direito público, que não foi desse modo que Montesquieu formulou a separação dos poderes (entendida como especialização e independência).

O ponto de partida da argumentação de Eisenmann é o conceito de poder legislativo: o poder de editar regras legislativas. Ser titular do poder legislativo significa ter competência para editar regras legislativas. O órgão legislativo é formado pela reunião dos

\footnotetext{
${ }^{7}$ Para uma abordagem histórica da separação dos poderes, ver W. B. Gwyn, The meaning of the separation of powers: an analysis of the doctrine from its origin to the adoption of the United States Constitution, New Orleans: Tulane University, 1965; Maurice Vile, Constitutionalism and the separation of powers, London: Oxford University Press, 1967; Michel Troper, La séparation des pouvoirs et l'histoire constitutionelle française, Paris: LJDG, 1980.

8 "Charles Eisenmann contre le mythe de la séparation des pouvoirs", Cahiers de Philosophie Politique: Montesquieu, Bruxelles: Ousia, 1985, pp. 67-79.

${ }^{9}$ Troper distingue princípio de política constitucional, ou seja, um princípio que orienta a elaboração de uma política constitucional, de princípio de interpretação de uma constituição já existente. A separação dos poderes pode assumir as duas formas (Ibid.).

10 "L'Esprit des Lois et la Séparation des Pouvoirs", in Cahiers de Philosophie Politique (Montesquieu), Bruxelas: Ousia, 1985, pp. 3-34 [publicado originalmente em Mélanges Carré de Malberg, Paris, 1933]. Esse texto é referido e analisado por Louis Althusser, em Montesquieu; la politique et l'histoire, Paris: Quadrige/PUF, 1992, pp. 98-108, por Michel Troper, em "Charles Eisenmann contre le mythe de la séparation des pouvoirs", Cahiers de Philosophie Politique: Montesquieu, Bruxelles: Ousia, 1985, pp. 67-79. No Brasil, foi Eros Roberto Grau quem, num artigo instigante, resgatou o trabalhos de Eisenmann e de Althusser ("Crítica da 'separação dos poderes': as funções estatais, os regulamentos e a legalidade no Direito brasileiro, as leis-medida”, in O Direito Posto e o Direito Pressuposto, São Paulo: Malheiros, 1996, pp. 167199).
} 
indivíduos e mesmo dos órgãos cuja vontade deve ser manifestada para a edição de regras legislativas. $^{11}$

Esta manifestação de vontade implica um consentimento de uma regra legislativa, ato que não decorre necessariamente da participação formal no processo legislativo. Assim, a iniciativa legislativa e o direito de participar da discussão dos projetos de lei não são atos legislativos, pois não consubstanciam um consentimento. $\mathrm{O}$ mesmo não ocorre com o poder de veto. O não-exercício deste poder, que equivale à sanção, é requisito para que a lei exista enquanto tal. O monarca, portanto, por ser titular da competência de sancionar (= não vetar) ou de vetar (= não sancionar), não só participa do processo legislativo, mas também do poder legislativo. ${ }^{12}$

Eisenmann sustenta que em Montesquieu a faculté d'empêcher (faculdade de impedir, ou seja, de bloquear uma decisão de outro órgão) - e não somente a faculté de statuer (faculdade de estatuir, ou seja, de determinar o conteúdo das regras legislativas) - é um modo de participar da função legislativa. Nas palavras do próprio Montesquieu:

"O poder [=órgão] executivo, como dissemos, deve participar da legislação através do direito de veto, sem o que seria despojado de suas prerrogativas. Mas, se o poder [=órgão] legislativo participar da execução, o poder [=órgão] executivo estará igualmente perdido.

"Se o monarca participasse da legislação pela faculdade de estatuir, não mais haveria liberdade. Porém, como é preciso que ele participe da legislação para se defender, cumpre que ele aí tome parte pela sua faculdade de impedir."13

No sistema de Montesquieu, portanto, o monarca investido do poder de veto é parte integrante do órgão legislativo. A distinção entre as faculdades de estatuir e de impedir é

\footnotetext{
${ }^{11}$ Para evitar confusões, adoto, na exposição do pensamento de Eisenmann, a sua própria terminologia, que distingue poder legislativo de órgão legislativo, o mesmo sendo válido para o executivo. Entretanto, quando as expressões Executivo e Legislativo aparecerem isoladas e com inicial maiúscula, estarei me referindo respectivamente ao Poder Executivo e ao Poder Legislativo. No texto, especialmente na exposição relativa a Montesquieu, órgão legislativo não é sinônimo de Parlamento. Ela designa o conjunto composto pelo Rei e pelo Parlamento, no exercício conjunto da função legislativa.

${ }^{12}$ No mesmo sentido, Hans Kelsen: "O chefe do departamento executivo exerce uma função legislativa quando tem direito de impedir, por meio de veto, que normas pronunciadas pelo órgão legislativo se tornem leis, ou quando tais normas não podem se tornar leis sem antes receber a sua aprovação" (Teoria geral do direito e do Estado, trad. Luís Carlos Borges, São Paulo: Martins Fontes, 1998, pp. 388-389). Entretanto, ao contrário de Eisenmann, Kelsen vê na iniciativa legislativa o exercício de função legislativa.

${ }^{13}$ Do Espirito das Leis, ed. brasileira, L. XI, Cap. VI, p. 153.
} 
originária da relação entre a Câmara Alta e a Câmara Baixa - Montesquieu tinha a intenção de, em algumas matérias, conferir aos nobres somente um poder de veto contra resoluções legislativas da Câmara Baixa.

Também o poder de julgar não tem titular exclusivo. As câmaras poderiam exercêlo. A Câmara Alta, por exemplo, julgaria os nobres, para evitar que eles fossem vítimas dos preconceitos dos magistrados populares.

O pressuposto do sistema constitucional de Montesquieu é a supremacia do poder legislativo. Para ele, há uma hierarquia das funções. A menos importante é a judicial trata-se de poder nulo, não político, sendo o juiz mero aplicador da lei, sem poder discricionário. Daí não fazer sentido, para ele, a regra da especialização funcional, sustentada por seus intérpretes tradicionais. Ora, como atingir o equilíbrio político se houvesse uma distribuição exclusiva de funções? Se estas não têm a mesma importância, o titular exclusivo do poder legislativo poderia se sobrepor aos demais.

O verdadeiro princípio defendido por Montesquieu, segundo Eisenmann, é o da independência jurídica recíproca do Parlamento e do Governo, ambos investidos do poder supremo de legislar. É esta repartição do poder legislativo entre o monarca, a Câmara Alta e a Câmara Baixa - representantes de forças sociais distintas - que garante a produção de uma legislação moderada e a manutenção da liberdade política, configurando-se um governo misto (combinação dos princípios monárquico, aristocrático e democrático). Qualquer alteração desta repartição de competências só poderia ser efetuada mediante lei, que deveria ser aprovada pelos três órgãos constitutivos do órgão legislativo. Ao aplicar as leis, o monarca não estaria se submetendo à vontade do Parlamento, mas sim a um preceito legal de cujo consentimento participou. Montesquieu, portanto, busca o equilíbrio social, pela limitação do poder da maioria para garantia dos interesses das minorias. ${ }^{14}$

Comentando os trabalhos de Eisenmann, Michel Troper ${ }^{15}$ afirma que a exposição correta - do pensamento constitucional de Montesquieu ilustra o fato de que os homens do século XVIII não aderiram à doutrina que hoje denominamos de "separação dos poderes".

\footnotetext{
${ }^{14}$ Ver Michel Troper, ob cit., p. 75.

15 "Charles Eisenmann contre le mythe de la séparation des pouvoirs", Cahiers de Philosophie Politique: Montesquieu, Bruxelles: Ousia, 1985, pp. 67-79, e "Actualité de la séparation des pouvoirs", in Pour une théorie juridique de l'État, Paris: PUF, 1996, pp. 225-236.
} 
A sua preocupação consistia em conceber um sistema no qual o maior poder se conciliasse com a maior liberdade. A conhecida definição de Montesquieu segundo a qual liberdade é o direito de fazer o que as leis permitem ${ }^{16}$ derivaria de uma analogia com a liberdade do homem na natureza, obtível com o conhecimento das leis naturais - o homem em sociedade é livre porque conhece as leis postas, podendo prever se será ou não punido por suas ações. $\mathrm{O}$ indivíduo não pode ser constrangido a fazer o que a lei não lhe obriga, nem a fazer o que ela lhe permite. ${ }^{17} \mathrm{O}$ sistema que se busca construir não terá por objetivo preservar uma esfera de autonomia individual ao modo dos liberais modernos, mas tãosomente garantir que os indivíduos sejam submetidos exclusivamente à lei, livres dos caprichos dos homens. ${ }^{18}$

O que Montesquieu pretendeu, portanto, foi garantir que as funções estatais não ficassem acumuladas nas mesmas mãos (não-cumulação), e não a especialização, nem a separação funcional.

O outro princípio que Eisenmann infere do texto de Montesquieu é o da independência jurídica recíproca do Parlamento e do Governo. Esta independência é viabilizada, como já foi explicado, pela distribuição de competências legislativas - lembrese que o poder legislativo é o poder supremo - (faculdade de estatuir e de impedir) entre os dois, resguardando a independência jurídica de ambos. A conhecida fórmula "il faut que le pouvoir arrête le pouvoir" é aplicada, na verdade, ao poder legislativo, o que é bem diferente da interpretação tradicional de Montesquieu.

O sistema constitucional de Montesquieu não pode, portanto, ser designado pela expressão "separação dos poderes"19, a menos que esta designe tão-somente o princípio de não-cumulação. Esse princípio, adotado por qualquer constituição não absolutista, por si só não determina a composição dos órgãos estatais, nem suas relações funcionais. São as regras específicas de cada constituição que vão dar concreção ao princípio da nãocumulação.

\footnotetext{
${ }^{16}$ Do Espírito das Leis, L. XI, Cap. III.

${ }^{17}$ Do Espirito das Leis, L. XI, Cap. IV.

${ }^{18}$ Cf. Michel Troper, "Actualité de la séparation des pouvoirs", in: Pour une théorie juridique de l'État, Paris: PUF, 1996, p. 228.

${ }^{19}$ É a conclusão de Eisenmann, escandalosa para a interpretação tradicional de Montesquieu. Ob cit., p. 34.
} 
Como ressalta Michel Troper ${ }^{20}$, a contribuição de Charles Eisenmann não consiste somente em reinterpretar ou interpretar corretamente Montesquieu. Discípulo e tradutor de Hans Kelsen, Eisenmann postula que uma teoria científica das funções do Estado deve defini-las materialmente, para só depois examinar a sua repartição entre os órgãos. Daí a divergência entre Eisenmann e os juristas franceses - que muito têm influenciado o Direito Público brasileiro -, que fazem o caminho inverso, sustentando uma concepção formal das funções estatais, privilegiando os órgãos.

Ao romper com a visão jurídica francesa convencional, Eisenmann abandonou o ponto de vista metajurídico habitual e passou a examinar as competências tal qual se encontram expostas no cap. VI do Livro XI do Espírito das Leis. Pôde, assim, ler Montesquieu com outros olhos, à luz de uma teoria pura do direito. ${ }^{21}$

Nuno Piçarra atribui exatamente à tradição positivista alemã, que reduz o Estado ao Direito, a conversão da distinção entre funções legislativa, executiva e judicial - originada da preocupação com a liberdade e segurança individuais - numa teoria das funções estatais materialmente definidas (por exemplo, lei como norma geral abstrata e inovadora do ordenamento) com pretensão de validade universal: “a teoria da separação dos poderes passou a identificar-se com uma teoria da diferenciação dogmática das funções estaduais [estatais], de acordo com critérios jurídicos".22

A convivência de um critério material de classificação das funções estatais com uma classificação formal ou subjetiva (por exemplo, função legislativa como o conjunto de atos realizados pelo órgão legislativo), que converte o princípio da separação dos poderes

\footnotetext{
20 "Charles Eisenmann contre le mythe de la séparation des pouvoirs", Cahiers de Philosophie Politique: Montesquieu, Bruxelles: Ousia, 1985, pp. 75 e ss.

${ }^{21}$ Também para Kelsen "não se pode falar de uma separação entre a legislação e as outras funções do Estado no sentido de que o chamado órgão 'legislativo' - excluindo os chamados órgãos 'executivo' e "judiciário' seria, sozinho, competente para exercer essa função. A aparência de tal separação existe porque apenas as normas gerais criadas pelo 'órgão' legislativo são designadas como 'leis' (leges). Mesmo quando a constituição sustenta expressamente o princípio da separação de poderes, a função legislativa - uma mesma função, e não duas funções diferentes - é distribuída entre vários órgãos, mas apenas a um deles é dado o nome de órgão 'legislativo'. Esse órgão nunca tem um monopólio da criação de normas gerais, mas, quando muito, uma determinada posição favorecida, tal como a previamente caracterizada. A sua designação como órgão legislativo é tão mais justificada quanto maior for a parte que ele possui na criação de normas gerais" (Teoria geral do direito e do Estado, ob. cit., p. 390). Ainda segundo Kelsen, os tribunais exercem uma função legislativa quando declaram a inconstitucionalidade de uma lei e quando sua decisão, num caso concreto, se torna um precedente para a decisão de outros casos similares (p. 389).

${ }^{22}$ Nuno Piçarra, A Separação dos Poderes como Doutrina e Princípio Constitucional: um Contributo para o Estudo das suas Origens e sua Evolução, Coimbra: Coimbra Ed., 1989, pp. 247 e ss.
} 
numa "categoria com valor apriorístico", ${ }^{23}$ provoca uma grande confusão doutrinária. Essa confusão, aliada à falência da tripartição como classificação universal das funções estatais, e à relatividade dos critérios de caracterização material das funções estatais, faz com que a busca de uma teoria geral das funções estatais como elemento essencial do princípio da separação dos poderes venha sendo substituída pela análise das funções estatais no âmbito de uma constituição concreta.

Esta evolução está, aliás, em consonância com a progressiva transição de um método abstrato-dedutivo para um método normativo concreto na abordagem e no tratamento dogmático do princípio da separação dos poderes. Ele tende, hoje, a construirse a partir da ordenação de competências jurídico-constitucionais concreta. ${ }^{24}$

Nesse sentido, Kelsen escreveu em Berkeley, na mesma linha de Eisenmann, doze anos depois:

"Portanto, foi um erro descrever o princípio fundamental da monarquia constitucional como a 'separação de poderes'. As funções originalmente combinadas na pessoa do monarca não foram 'separadas', mas antes divididas entre o monarca, o parlamento e os tribunais. Os 'poderes' legislativo, executivo e judiciário, que os que formularam o princípio de separação tinham em mente, não são três funções do Estado distintas logicamente, mas as competências que o parlamento, o monarca e os tribunais adquiriram ao longo da história na chamada monarquia constitucional. A significação histórica do princípio chamado 'separação de poderes' encontra-se precisamente no fato de que ele opera antes contra uma concentração que a favor de uma separação de poderes.

$[\ldots]$

"Da mesma maneira, a participação do monarca na legislação significa que a sua competência inclui tanto a função legislativa quanto a executiva, e, assim, que o poder legislativo está dividido entre o monarca e o parlamento." 25

\footnotetext{
${ }^{23}$ Id ibid, p. 249.

${ }^{24}$ Nuno Piçarra, ob cit, p. 264.

${ }^{25}$ Hans Kelsen, Teoria geral do direito e do Estado, ob. cit., pp. 402-403.
} 
É pelo fato de trabalhar com uma classificação material das funções estatais que Kelsen, indo além de Eisenmann, pode chegar à idéia do juiz constitucional como um legislador negativo, rompendo então definitivamente com a visão simplista da correspondência biunívoca entre órgãos e funções. Isso ficou ainda mais claro quando, na sua polêmica com Carl Schmitt, Kelsen sustentou enfaticamente o papel da Corte Constitucional como guardiã da constituição. ${ }^{26}$

A constatação de uma zona cinzenta entre o julgar e o legislar, presente em Kelsen, faz inclusive com que um autor como Duncan Kennedy aponte a coincidência - somente em relação a este aspecto -, entre perspectivas tão díspares quanto a do positivismo jurídico e a do Critical Legal Studies. ${ }^{27}$ Entretanto, para por aí a contribuição do normativismo para a compreensão da Constituição.

Tanto a visão positivista da Constituição quanto a releitura que Eisenmann faz de Montesquieu restam ainda insuficientes para uma análise profunda da dinâmica constitucional contemporânea. Para entender os poderes normativos da burocracia e o seu controle por um tribunal constitucional, faz-se necessário ir além da mera exegese de Montesquieu, assim como abandonar uma visão normativista da constituição.

A busca da interpretação correta de Montesquieu e do pensamento da sua época tem a virtude de refutar o argumento de autoridade da doutrina clássica da separação dos poderes. Entretanto, ela deixa sem solução três problemas. Em primeiro lugar, o papel do juiz no sistema constitucional de Montesquieu: se ele é um poder nulo, apenas "a boca que pronuncia a lei”, a separação dos poderes relida por Eisenmann permanece incompatível com o controle de constitucionalidade das leis. Em segundo lugar, não havia obviamente no pensamento de Montesquieu uma preocupação democrática. Seu pensamento estava voltado para a preservação da liberdade mediante uma repartição de competências que levasse à elaboração de uma legislação moderada - um governo misto. Por fim, não fazia parte das preocupações de Montesquieu o exercício de poder normativo pela burocracia certamente não era parte de seu universo um corpo de tecnocratas encarregados da complexa tarefa de regular o mercado financeiro.

\footnotetext{
${ }^{26}$ Hans Kelsen, Quien debe ser el defensor de la constitución, Madrid: Technos, 1995.

${ }^{27}$ Duncan Kennedy, A critique of adjudication (fin de siècle), Cambridge, Massachusetts: Harvard University Press, 1997, pp. 31 e 37.
} 
Da mesma forma, na fundação da nação norte-americana, o papel da burocracia não foi incorporado ao desenho constitucional. Atualmente, mesmo nos E.U.A., onde já se acumulou, desde o New Deal, um enorme conjunto de reflexões e experiências institucionais concernentes à burocracia, muito ainda há de ser feito quanto à tarefa de repensar a separação dos poderes com vistas aos novos ideais que legitimam a estrutura constitucional de uma sociedade complexa. Dentre estes, deve ocupar um importante lugar a competência profissional indispensável para o desempenho das complexas funções do Estado contemporâneo. A todo momento, entretanto, a reverência a Montesquieu e Madison parecem impedir o rompimento com a configuração institucional clássica. ${ }^{28}$

Teríamos então, ao repensar a separação dos poderes, que abandonar completamente Montesquieu? Acredito que não. Como todo clássico, ele sempre tem algo a nos dizer. Seguindo Michel Troper, sustento que a compreensão da constituição para além do normativismo encontra na concepção mecanicista de Montesquieu um caminho fértil para a análise das instituições contemporâneas.

Troper aponta a "máquina" e a "norma" como dois modelos de constituição. ${ }^{29}$ Trata-se, ao mesmo tempo, de modelos (i) de elaboração e (ii) de interpretação e análise das constituições. Cada um deles pode ser visto, portanto, do ponto de vista da eficácia e do ponto vista da análise constitucional.

Do ponto de vista da eficácia, o modelo normativo parte da premissa de que a constituição tem um caráter obrigatório: ela é norma que deve ser seguida pelas autoridades constituídas. A constituição pode prever, inclusive, a existência de um órgão de controle - controle judicial, por exemplo - dotado de competência para aplicar sanções às autoridades que não observarem as regras constitucionais.

Enquanto método de análise e interpretação, conceber a constituição como norma implica guiar-se por questões a serem resolvidas por uma ciência do direito constitucional,

\footnotetext{
${ }^{28}$ Bruce Ackerman, em instigante artigo, é taxativo: "We honor Montesquieu and Madison best by seeking new constitutional forms to master these challenges, even at the cost of transcending familiar trinitary formulations" ("The new separation of powers", Harvard Law Review 113 (2000): 633-729).

${ }^{29}$ Cf. Michel Troper, La théorie du droit, le droit, l'État, Paris: PUF, 2001, pp. 147-162 (chapitre X: "La machine et la norme. Deux modèles de constitution").
} 
um ramo da dogmática jurídica. Significa, portanto, indagar qual conduta é exigida pela constituição, ou se determinada conduta é ou não lícita.

Em ambos os aspectos o modelo normativo de constituição enfrenta sérios problemas. A eficácia da constituição repousa na submissão a um conjunto de obrigações. Se o controlador - um tribunal, por exemplo - é ele próprio uma autoridade que deve respeitar as regras constitucionais, a constituição somente será eficaz (i) se o seu texto for suficientemente claro a ponto de não permitir distintas interpretações; e (ii) se as autoridades não tiverem nenhum grau de discricionariedade para agir. Como essas condições não se verificam na prática, nem obrigações nem sanções são capazes de garantir a eficácia. Esta passa a depender da boa vontade e da boa fé das autoridades constituídas e dos controladores. A necessidade de um controle externo leva à clássica questão: quem guarda o guardião?

O controle de constitucionalidade demonstra isso exemplarmente. Dentro da visão realista que orienta sua concepção do direito, Troper vê o papel do juiz constitucional como de criação do direito, e não de mera constatação objetiva da conformidade de uma norma em relação a outra. Como não há um texto superior ao da constituição, nem uma outra instância de recurso além da corte constitucional, essa garantia externa da eficácia da constituição revela-se falha. Prevalece, no final, o conjunto de valores que informam a interpretação/criação realizada pelo tribunal.

A necessidade e a tentativa de justificar esse papel criador do direito pelo juiz leva à adoção de um outro modelo de constituição: a máquina, ou modelo mecanicista. Quando se afirma que a atuação do tribunal justifica-se porque ele seria uma espécie de contrapoder incumbido de impedir a ditadura da maioria. Isso nada mais é, como ressalta Troper, do que retomar a idéia de equilíbrio de poderes de Montesquieu: o jogo de poderes e contra-poderes que garante a liberdade.

As faculdades de estatuir e de impedir analisadas por Montesquieu configuram um modelo do qual se espera que "a própria organização do sistema determine os comportamentos aos quais os governantes não poderão se subtrair". ${ }^{30}$ Ao invés de uma

${ }^{30}$ Ibid., p. 147. 
garantia externa de eficácia, o que se tem são garantias internas. É um modelo de engenharia institucional:

“A relação entre liberdade política e a constituição é realmente concebida como de causalidade. Segundo o espírito de Montesquieu, a liberdade não é assegurada na Inglaterra porque a constituição ordenava ao poder executivo que agisse conforme a lei; a lei não era moderada porque a constituição prescrevia a moderação ao legislador. Esses resultados eram obtidos porque, devido a uma distribuição de poderes que levava em conta os interesses e as paixões, as autoridades constitucionais seriam constrangidas a realizar acordos e não poderiam produzir leis que não fosse moderadas." 31

Troper ressalta que essa idéia já estava presente em autores e homens públicos como Blackstone, Thomas Paine e Madison. Ela apareceu também nas assembléias da Revolução Francesa, especialmente na Assembléia nacional constituinte de 1789.

É nesse sentido de repartição de competências que deve ser entendido o art. 16 da Declaração de direitos do homem e do cidadão:

“Toda Sociedade na qual a garantia dos Direitos não está assegurada, nem a separação dos Poderes definida, não tem Constituição".

A relação de necessidade entre liberdade e repartição de poderes é tal que esta confunde-se com a própria essência da constituição. Ao invés de um órgão de controle externo, seriam os controles internos decorrentes do jogo de competências que garantiria a eficácia da constituição. ${ }^{32}$ Troper reproduz um panfleto anônimo que bem expressava esse espírito do constitucionalismo do século XVIII, preocupado com a liberdade e com a inviolabilidade da constituição:

\footnotetext{
${ }^{31}$ Ibid., p. 149 (tradução livre).

${ }^{32}$ Como registra Troper, foi rejeitada por unanimidade a proposta de Sieyès de criação do "jurie constitutionnaire", um órgão de controle que impediria as violações à constituição. O argumento que prevaleceu foi exatamente o de que não era necessário um órgão de controle, pois a divisão do poder legislativo já configurava uma garantia interna suficiente (Ibid., p. 151). O texto de Troper contém vários exemplos da história constitucional francesa, que não vou, aqui, reproduzir.
} 
"Grande leçon pour nous! Je le dis san scrupule

Désirons-nous sincèrement

Un bon gouvernement?

Aux règles de la mécanique

Soumettons l'ordre politique

Toute-puissance tend à l'envahissement

Eh bien! Créons une force capable

De fixer des pouvoirs la borne indispensable

De maintenir avec sévérité

Entre eux une distance égale

En forçant chaque autorité

Prête à sortir de sa sphère légale

À respecter les droits de sa rivale.

Ne souffrons pas enfin qu'un instrument grossier

Nous offre le modèle, en vain, d'un balancier." 33

Enquanto método de análise, o modelo mecanicista funda-se na noção de "constrangimento". No lugar do questionamento sobre a ilicitude de condutas, o que se indaga, aqui, é que tipo de comportamento dos poderes públicos é incentivado pela repartição constitucional de competências, ou ainda, tendo-se em vista uma conduta concreta, por que ela teria ocorrido.

A noção de Constituição enquanto máquina é extremamente fértil para a análise da dinâmica constitucional. Pode-se visualizar, dessa forma, como a análise de Montesquieu pode ser útil para a compreensão da democracia contemporânea, a partir da análise dos constrangimentos jurídicos e políticos que modelam a ação dos poderes públicos. Essa análise pode se dar em dois níveis.

O primeiro consiste na leitura da ação dos atores como estratégias formadas a partir dos constrangimentos. O segundo reside na explicação da evolução dos conceitos jurídicos e dos discursos sobre a constituição. Esta última forma de análise é o mote para o exemplo preferido de Troper: sua crítica ao controle de constitucionalidade, que ele considera

${ }^{33}$ Anonyme, Le balancier politique, ou projet d'additions et de corrections à fàire à la Constitution de 1793, avant de l órganizer; précédé de deux fables, Paris, an III, BN lb 41 1859, apud Ibid., p. 151. 
incompatível com a democracia. Quer seja a soberania popular identificada com a função legislativa do Parlamento, quer seja ela associada ao poder constituinte, a soberania popular é atropelada pela atuação do juiz constitucional que impede a promulgação de uma lei (sistema francês) ou anula uma lei já promulgada. Na medida em que interpreta a constituição, o juiz constitucional determina a norma constitucional - ele exerce um poder constituinte. ${ }^{34}$ Para Troper, aqueles que sustentam a compatibilidade do controle de constitucionalidade com a democracia precisam enfrentar o desafio de redefinir a própria democracia. $^{35}$

2. Separação dos poderes e democracia deliberativa

Recuperar o sentido da constituição enquanto máquina, da engenharia constitucional do século XVIII, nos ajuda a reelaborar a separação dos poderes para além de sua versão vulgar - a da correspondência biunívoca entre órgãos e funções. A separação dos poderes passa a ser entendida como equilíbrio de poderes (balance des pouvoirs). A constituição-máquina, entretanto, não tem uma forma única, a-histórica. Ela não pode ser pensada num vácuo ideológico. A maquinaria constitucional tem que estar a serviço de algum ideal político. Para os constitucionalistas do século XVIII, esse ideal era a liberdade que somente uma legislação moderada poderia garantir. Trataram então de pensar o "fatiamento" do mais importante dos poderes, o legislativo, entre o rei e o Parlamento. Para os juízes, nenhuma faculdade de estatuir ou impedir, mas tão somente a tarefa de aplicar a lei produzida pelo jogo de competências dos demais poderes.

Troper também não aceita que o tribunal constitucional participe deste jogo . A sua separação de poderes deita raízes numa concepção de democracia calcada na soberania popular: "entende-se por democracia um sistema no qual as normas gerais, principalmente as leis, são produzidas pelo povo ou por aqueles que ele elege". ${ }^{36}$

Ao comentar o conjunto de seu trabalho, Ricardo Guastini aponta a curiosa contradição de Troper: a todo seu esforço de desenvolver um realismo jurídico não corresponde uma leitura da democracia baseada num realismo político. Sua visão de

\footnotetext{
${ }^{34}$ Ibid., p. 192 (ver Chapitre XII: "Kelsen et le contrôle de constitutionnalité", pp. 173-193).

${ }^{35}$ Ibid., p. 162.

${ }^{36}$ Ibid., p. 193.
} 
democracia é ingênua, ao acreditar que a vontade popular é fielmente traduzida pelo resultado do processo legislativo. ${ }^{37}$

Torna-se necessário não somente libertar o modelo de constituição-máquina dessa concepção ingênua da democracia, mas também ir além do republicanismo que parece inspirá-la, para que ela dê conta da tarefa de compreender a dinâmica constitucional do Estado Regulador no contexto de uma sociedade complexa, marcada não somente pela coexistência de esferas autônomas, como a econômica e o administrativa, mas também pelo pluralismo cultural e social. Adoto, nesse passo, a distinção que Habermas desenvolve entre liberalismo e republicanismo, a partir do retrato que Frank Michelman faz do debate entre liberais e comunitaristas nos E.U.A. Essa distinção é feita em relação ao conceito de cidadão, ao conceito de direito e à natureza do processo de formação da vontade política. ${ }^{38}$

Na visão liberal, os direitos individuais dos cidadãos têm um caráter negativo, ou seja, dizem respeito à proteção de sua esfera de liberdade de escolha vis-à-vis o Estado e os demais cidadãos. Seus direitos políticos têm a mesma característica: ao eleger seus representantes, os cidadãos contribuem para a formação de uma vontade política que pode determinar o exercício do poder estatal de acordo com o interesse da sociedade. O objetivo do direito, portanto, é o reconhecimento e a garantia dos direitos individuais. A política é vista como "uma luta por posições que garantem acesso ao poder administrativo". 39 A disputa pelo voto, que franqueia aos partidos políticos o acesso ao poder, desenvolve-se num "mercado" político que molda a formação da vontade política. O aparato estatal, objeto da disputa, expressa o poder político pelo modus operandi da estrutura administrativa - espera-se que ele persiga os objetivos de toda a sociedade, e não dos interesses privados que a compõem. $\mathrm{Na}$ distinção entre Estado e sociedade, esta é concebida como "um sistema de interações entre pessoas e seu trabalho, estruturadas em torno do mercado". 40

${ }^{37}$ Cf. Ricardo Guastini, "Michel Troper sur la fonction juridictionnelle", Droits - Revue Française de Philosophie et de Culture Juridiques 37 (2003), pp. 111-122 (p. 122).

${ }^{38}$ Cf. Jürgen Habermas, The inclusion of the other: studies in political theory, edited by Ciaran Cronin and Pablo De Greiff, Cambridge, Massachusetts: The MIT Press, 1998, pp. 239-252 (chapter 9: "Three normative models of democracy").

${ }^{39}$ Ibid., p. 243.

${ }^{40}$ Ibid., p. 239. 
Já o modelo republicano de democracia não vê a sociedade estruturada primordialmente em torno do mercado, nem a política como mediadora entre Estado e sociedade. Além do poder administrativo e da busca dos interesses privados que se dá no mercado, a solidariedade desponta como terceira forma de integração social. A prioridade, aqui, é para a formação de uma vontade política fundada num entendimento mútuo ou num consenso construído de forma comunicativa. Há um fundamento ético para a política. A esfera pública política e a sociedade civil asseguram "o poder de integração e a autonomia da prática comunicativa dos cidadãos". ${ }^{41}$ Para o cidadão, o mais importante nesse modelo são as liberdades positivas, os direitos políticos de participação e comunicação, mediante os quais ele pode tornar-se sujeito de uma comunidade de cidadãos livres e iguais. $\mathrm{O}$ processo político tem como paradigma o diálogo, e não o mercado. Decisões majoritárias nascem de uma prática discursiva - um poder comunicativo que se distingue do poder administrativo do aparato estatal, devendo conformar este último: "o poder administrativo só pode ser exercido com base em políticas e dentro de limites traçados por leis geradas pelo processo democrático". 42

Por sua vez, o modelo de democracia deliberativa baseado na teoria do discurso de Habermas combina partes dos dois modelos anteriores, mas rejeita tanto a concepção de Estado enquanto comunidade ética quanto o Estado como guardião de uma sociedade estruturada em torno do mercado. Sua preocupação volta-se para o procedimento de deliberação e de tomada de decisões: as regras do discurso e as formas de argumentação e não mais direitos fundamentais universais ou a vida ética concreta de uma determinada comunidade - serão o contexto privilegiado para o exercício da razão prática. A sociedade não é vista como um ator coletivo centrado no Estado nem tampouco em regras do jogo que regulam interesses modelados pela racionalidade do mercado. A base desse modelo é um tipo de ação voltada para o entendimento combinada com uma premissa que rompe com a filosofia do sujeito: "a intersubjetividade de alto nível dos processos comunicativos que se desenvolve, de um lado, nas deliberações institucionalizadas dos órgãos parlamentares, e, de outro, nas redes informais da esfera pública". São modos de comunicação desprovidos de sujeito .

\footnotetext{
${ }^{41}$ Ibid., p. 240.

42 Ibid., p. 244.
} 
Tal como no modelo republicano, cumpre, aqui, atentar para a forma como o poder comunicativo modela o poder administrativo. Entretanto, ao contrário daquele modelo, na democracia deliberativa a legitimidade do direito não se funda na unanimidade de opiniões de uma comunidade, mas nas condições de comunicação e nos procedimentos institucionalizados que, ao viabilizar o balanceamento dos diversos interesses e ideais que convivem numa sociedade plural, levam à formação de uma vontade política que cria, de forma mais ou menos racional, regras para matérias relevantes para todos. O resultado desse modelo, portanto, do ponto de vista normativo, é pensar o Estado e a sociedade de forma distinta do liberalismo e do republicanismo:

\footnotetext{
"As implicações normativas são óbvias: a força integradora da solidariedade, que não pode ser obtida somente das fontes de ação comunicativa, deveria se desenvolver mediante procedimentos de deliberação democrática e de tomada de decisões juridicamente institucionalizados, adquirindo a força necessária para se afirmar perante as outras duas forças sociais - o dinheiro e o poder administrativo." 43
}

É interessante notar que, no caso da regulação financeira, poder administrativo e dinheiro combinam-se de forma peculiar: a burocracia reguladora do mercado financeiro edita normas jurídicas cujo objetivo é a manutenção de um regime monetário que sustenta a reprodução de um regime de acumulação. O modelo de democracia deliberativa fundado na teoria do discurso oferece um rico instrumental analítico para o estudo do problema do déficit democrático da regulação financeira, por três razões: (i) ele não assume uma postura idealista em relação ao processo político, reconhecendo, ao contrário, a ação estratégica que indivíduos e grupos empreendem para a defesa de seus interesses concretos, ou seja, reconhecendo a barganha como uma das formas de comunicação; ${ }^{44}$ (ii) ele não alimenta a expectativa ingênua de que a opinião pública comandará diretamente os rumos da sociedade, ou mais especificamente, no campo do presente trabalho, o funcionamento da moeda e do sistema financeiro, deixando claro que ela poderá tão somente "conduzir o uso do poder administrativo numa determinada direção"; 45 e (iii) ele

\footnotetext{
${ }^{43}$ Ibid., p. 249 (tradução livre).

${ }^{44}$ Ibid., p. 245. Ver também Jürgen Habermas, Between facts and norms: contributions to a discourse theory of law and democracy, translated by William Rehg, Cambridge, Massachisetts: The MIT Press, 1996, p. 177.

${ }^{45}$ Ibid., p. 250 (tradução livre).
} 
reconhece como democrático o papel do controle de constitucionalidade numa sociedade complexa.

Esse último desdobramento do pensamento de Habermas, fundamental para o presente trabalho, só pode ser entendido com a explicitação do significado que a separação dos poderes adquire quando pensada não de acordo com o liberalismo da doutrina predominante no Brasil, nem conforme o republicanismo de Michel Troper, mas plantada no solo fértil da democracia deliberativa. É possível, portanto, pensar a separação dos poderes - enquanto equilíbrio entre os poderes - de modo que a constituição-máquina esteja a serviço não da soberania popular tal qual ela é concebida em termos republicanos, mas funcionando em prol da institucionalização dos procedimentos que permitem a uma sociedade complexa, em meio à imensa diversidade de interesses, ideais e culturas, controlar de forma democrática o poder administrativo que, imbricado com dinheiro, mantém a coesão social. Em outras palavras, a separação dos poderes deve estar a serviço do reforço da relação entre o poder comunicativo e o poder administrativo. ${ }^{46}$

Para tanto, é necessário enfatizar as diferentes formas de comunicação e os respectivos padrões de argumentação que caracterizam as funções de legislar, julgar e administrar. Isso é extremamente importante para a democracia deliberativa, na medida em que a repartição de competências entre as autoridades públicas reflete a "distribuição das possibilidades para acesso a diferentes tipos de razões" e formas de comunicação. ${ }^{47} \mathrm{O}$ Judiciário, por exemplo, só pode ter acesso a razões de caráter normativo, pragmático e empírico na medida em que elas se encaixem na sua tarefa de aplicação da lei de modo coerente, ou seja, mediante produção de decisões consistentes ao longo do tempo.

Ao associar, inicialmente, a configuração institucional clássica da separação dos poderes - divisão funcional dos poderes - às exigências de uma teoria discursiva do direito, Habermas parece de aderir àquela visão simplista, criticada no início deste capítulo. Se essa interpretação do seu pensamento estivesse correta, o modelo de democracia deliberativa que ele desenvolve consubstanciaria um enorme retrocesso no debate contemporâneo sobre a organização dos poderes estatais.

\footnotetext{
${ }^{46}$ Cf. Jürgen Habermas, Between facts and norms, ob. cit., pp. 186-193.

${ }^{47}$ Ibid., p. 192.
} 
Na verdade, o que Habermas realiza, nesse passo da ambiciosa empreitada teórica de Faticidade e Validade, é a fundamentação da separação dos poderes clássica de acordo com as exigências normativas da democracia deliberativa. Ele não sustenta que essa formulação clássica continua válida. Muito pelo contrário, o desenvolvimento do tema da separação dos poderes em seu trabalho dá um segundo passo, deixando claro que uma perspectiva baseada na configuração institucional clássica da separação dos poderes "legislatura", "judiciário" e "administração" - é limitada por adotar como referência uma estrutura concreta herdada:

“Uma visão como essa carece do nível de abstração de acordo com o qual brevemente indicamos a especificação teórico-discursiva das funções de legislação, aplicação e implementação. Somente quando se abordam essas funções num nível abstrato, em termos da distribuição dos diferentes tipos aceitáveis de argumentos e as correspondentes formas de comunicação, pode-se avaliar a adequação das várias formas mediante as quais os princípios decorrentes da lógica dos poderes separados têm sido institucionalizados." ${ }^{48}$

O processo de materialização do direito desarranja de tal forma o esquema clássico que a lógica da separação dos poderes só pode ser concretizada a partir do desenvolvimento de novas estruturas e novos procedimentos. As funções de legislar, aplicar e implementar serão repartidas e realocadas, dando origem a procedimentos "quase-judiciais", "quase-parlamentares", bem como a procedimentos que levem à formação de compromissos entre grupos antagônicos, além de outros. ${ }^{49} \mathrm{O}$ importante é que este exercício de "imaginação institucional e experimentação cuidadosa" ${ }^{\text {"50 }}$ seja orientado normativamente por uma visão do Estado e do direito baseada em princípios de acordo com os quais o direito legítimo nasce do poder comunicativo e este é convertido em poder administrativo por meio do direito produzido pelo Estado. Em outras palavras: o direito não pode ser somente o código de poder de acordo com o qual funciona o processo administrativo. Ele deve ser também o medium que transforma o poder comunicativo em poder administrativo. ${ }^{51}$

\footnotetext{
${ }^{48}$ Ibid., p. 193 (tradução livre).

${ }^{49}$ Ibid.

${ }^{50}$ Ibid., p. 441.

${ }^{51}$ Ibid., p. 169.
} 
Por materialização do direito, entende-se, aqui, a tendência anti-formalista do desenvolvimento jurídico moderno. Em Economia e Sociedade, Weber vê o desenvolvimento geral do direito, do ponto de vista teórico, em quatro estágios: (i) a revelação jurídica carismática por meio dos "profetas da lei"; (ii) a criação empírica e descoberta do direito pelos honoratiores (adesão aos precedentes); (iii) a imposição do direito por poderes teocráticos ou seculares; (iv) a elaboração sistemática do direito e profissionalização da justiça, que passa a ser desenvolvida por pessoas formadas por um ensino jurídico que os treinou conforme uma visão lógico-formal do direito. ${ }^{52}$

Esse desenvolvimento do direito acompanha o processo mais geral de racionalização, bem como de autonomização das esferas sociais. Embora historicamente ele não tenha ocorrido da mesma forma em todos os lugares, o esquema oferecido por Weber é fundamental para o entendimento das características essenciais do direito moderno, compreendido enquanto direito formal:

\begin{abstract}
"Nessa perspectiva, as qualidades formais do direito emergem da seguinte maneira: originada nos procedimentos jurídicos primitivos de uma combinação entre o formalismo condicionado pela magia e a irracionalidade condicionada pela revelação, elas evoluem para uma sistematização e uma racionalidade jurídica e lógica cada vez mais especializadas, experimentando, algumas vezes, uma passagem pelos juízos de conveniência informais e materiais condicionados pela teocracia ou pelo patrimonialismo., ${ }^{, 53}$
\end{abstract}

Produto do processo de racionalização, peculiar ao Ocidente, o direito formal passa a sofrer, segundo Weber, ameaças de todos os lados. Sindicatos e intelectuais engajados demandam um "direito social” que fuja à lógica do mercado. Dos juízes, a Escola do "Direito Livre" exige um papel mais criativo do que o de mero aplicador da lei, que reproduz injustiças. O júri popular, ao confiar aos leigos julgamentos criminais, funciona como uma "justiça de cadi". No direito privado, cada vez mais se exige a consideração da "intenção" das partes, da "boa fé" e dos "bons" usos e costumes comerciais. Os exemplos multiplicam-se. São sinais de irracionalidade e clamor por justiça material. Argumentos

\footnotetext{
${ }^{52}$ Cf. Max Weber, Economy and Society: an outline of interpretative sociology, v. 2, edited by Guenther Roth and Claus Wittich, New York: Bedminster Press, 1968, p. 882.

${ }^{53}$ Ibid., p. 882 (tradução livre).
} 
éticos, econômicos e sociológicos substituem os conceitos jurídicos e a argumentação lógico-formal.

A hipótese weberiana é de que tudo isso decorre necessariamente do "conflito insolúvel entre os princípios formais e materiais da justiça, que podem se chocar mesmo quando seus respectivos defensores pertencem a uma mesma classe social". ${ }^{54}$ Essa tensão entre o formal e o material é exemplificada também pelo direito privado: ao mesmo tempo em que a racionalização do direito e do processo judicial trouxeram a segurança jurídica indispensável para o desenvolvimento da empresa capitalista, o espírito prático dos homens de negócios e as necessidades concretas da economia não podem se satisfazer com o formalismo da cultura jurídica profissional: “As expectativas das partes são orientadas para o sentido econômico ou quase utilitário de uma proposição jurídica. Entretanto, do ponto de vista da lógica jurídica, esse sentido é 'irracional". 55

A idéia de um sentido, de uma intenção, ou ainda, de uma finalidade no direito é a expressão clara da tendência de sua materialização. Essa tendência é o tema central, por exemplo, da obra de von Ihering:

"Tudo que encontramos no fundamento do direito deve sua origem a uma finalidade e existe para realizar alguma finalidade. O direito como um todo é simplesmente uma criação da finalidade [...]. É tarefa da ciência - tanto no que se refere à história da formação do direito quanto à formação da crosta terrestre reconstruir os processos reais, por meio da idéia de finalidade. Para aqueles que não têm receio de investigar e refletir, é no campo do direito, como em nenhum outro, que a finalidade é prenhe de descobertas. Nisso consiste a mais importante tarefa da teoria da ciência do direito [...]." 56

O debate em torno da finalidade do direito e a tendência de crescimento de seus elementos materiais tornou-se central na agenda do pensamento jurídico. No campo da argumentação e da metodologia jurídicas, trabalhos como os de Ronald Dworkin, ${ }^{57}$ Robert

\footnotetext{
${ }^{54}$ Ibid., p. 893 (trad. livre).

${ }^{55}$ Ibid., p. 885 (trad. livre).

${ }^{56}$ Rudolf von Ihering, Law as means to an end, trad. Isaac Husik, Boston: The Boston Book Company, 1913, p. 330 [reimpressão pela The Law Book Exchange, 1999].

${ }_{57}$ Ronald Dworkin, Taking rights seriously, Cambridge: Harvard University Press, 1977.
} 
Alexy $^{58}$ e Friedrich Müller ${ }^{59}$ expressam bem a tentativa de superar as premissas e os desdobramentos do positivismo jurídico de Hart e Kelsen. ${ }^{60} \mathrm{O}$ desafio, para aqueles e outros autores contemporâneos, é desenvolver uma argumentação jurídica que possa incorporar de forma racional os elementos materiais - morais, éticos, políticos e econômicos - do direito sem que a interpretação do direito confunda-se com um exercício de discricionariedade. No plano da teoria do direito, essa empreitada é uma resposta ao ceticismo positivista, ${ }^{61}$ bem como à crítica que Carl Schmitt fez - neste ponto afinado com Weber $^{62}-$ da "ditadura dos valores".

Em sua resposta às críticas de Dworkin, Hart, no posfácio à segunda edição de seu $O$ conceito de direito, insistiu na tese da discricionariedade judicial que se desenvolve nos hard cases. Para ele, a teoria dos princípios de Dworkin não resolve o problema de que não há, nos casos difíceis, uma norma jurídica clara a ser aplicada. O juiz tem, portanto, que criar a norma. Não o faz da mesma forma que o legislador, mas efetivamente cria direito. À crítica de Dworkin ao caráter anti-democrático dessa atuação legislativa dos juízes, por não serem estes eleitos, Hart responde com um realismo implacável:

\begin{abstract}
“[A] delegação de poderes legislativos limitados para o executivo é uma característica familiar das democracias modernas e uma tal delegação para o judiciário não parece ser uma ameaça maior do que aquela à democracia. Em ambas as formas de delegação um legislativo eleito terá normalmente um controle residual e pode rejeitar ou alterar quaisquer leis que ele considere inaceitáveis." ${ }^{63}$
\end{abstract}

\footnotetext{
${ }^{58}$ Robert Alexy, Teoría de los derechos fundamentales, Madrid: Centro de Estudios Constitucionales, 1993.

${ }^{59}$ Friedrich Müller, Discours de la méthode juridique, trad. Olivier Jouanjan, Paris: PUF, 1996.

${ }^{60}$ No Brasil, os trabalhos de Eros Roberto Grau têm perseguido a mesma agenda. Ver, do autor, $A$ ordem econômica na Constituição de 1988, $7^{\mathrm{a}}$. ed., São Paulo: Malheiros, 2002, pp. 81-128 (capítulo 3: "Os princípios e as regras jurídicas"), e Ensaio e discurso sobre a interpretação/aplicação do direito, São Paulo: Malheiros, 2002.

${ }^{61}$ Cf. o posfácio de Hart à segunda edição de The concept of law (London: Oxford University Press, 1994, pp. 238-276).

${ }^{62}$ As afinidades entre Weber e Schmitt são limitadas. Como demonstra Michel Coutu, o pensamento de Weber pode ser descrito, principalmente a partir da sua visão da democracia plebiscitária, como uma combinação complexa de normativismo e decisionismo. Ao contrário de Schmitt, Weber sustenta a importância do Parlamento e dos partidos políticos ("Rationalité juridique et légitimité du droit chez Max Weber", in Pierre Lascoumes (dir.), Actualité de Max Weber pou la sociologie du droit, Paris: LGDJ, 1995 , pp. 211-219)

${ }^{63}$ Ibid., p. 275. Brian Leiter traça os vínculos internos entre a tese hartiana da discricionariedade judicial e o realismo jurídico. Segundo ele, os realistas norte-americanos podem ser considerados positivistas "tácitos" ("Legal realism, hard positivism, and the limits of conceptual analysis", in Jules Coleman (ed.), Hart's postscript: essays on the Postscript to The Concept of Law, London: Oxford University Press, 2001, pp. 355370). Duncan Kennedy também aponta a premissa compartilhada por autores com pensamentos tão distintos
} 
Como já referido supra, a posição de Kelsen não é muito diferente. Sua conhecida concepção do juiz constitucional como um "legislador negativo" aparece não somente na Teoria Geral do Direito e do Estado, mas também no seu debate com Carl Schmitt, ${ }^{64}$ que considerava antidemocrática a jurisdição constitucional. Em sua brilhante contestação da tese de Schmitt, Kelsen demonstra como ele retoma a doutrina do poder neutro de Benjamin Constant, transferindo-a da figura do monarca para o chefe de Estado republicano, ao interpretar a Constituição de Weimar e concluir que o Presidente do Reich é que deveria ser o "guardião da constituição".

Para Kelsen, a posição de Schmitt, ao pretender afastar o controle de constitucionalidade - desqualificando-o como uma forma de atividade legislativa antidemocrática -, é politicamente coerente com a sua concepção de Estado total, avessa ao pluralismo político e ao papel que poderia ser exercido por um tribunal constitucional independente em meio aos conflitos envolvendo o Parlamento e o Executivo. Sustentar o papel do Presidente do Reich como guardião da constituição significa consagrar institucionalmente o Estado total, fundado na supressão da oposição entre Parlamento e Executivo, bem como entre Estado e sociedade. O chefe de Estado encarnaria a vontade coletiva unitária: ele exerceria o controle de constitucionalidade numa sociedade supostamente homogênea, a partir de um Estado neutro.

Um tribunal constitucional comprometido com a guarda da constituição é incompatível com o princípio de totalidade do pensamento schmittiano, que termina por confundir intenções teóricas com intenções jurídico-políticas, teoria do direito com política do direito. A conveniência política do tribunal constitucional, segundo Kelsen, consiste em fragmentar o Estado, efeito indesejável para o estado total defendido por Schmitt. O fato de uma decisão do tribunal constitucional poder ser considerada política - no sentido de uma decisão que visa à resolução de conflitos - não representa, para Kelsen, um problema, na medida em que o processo de exercício do poder estatal não se exaure com a promulgação da lei. Nesse sentido, toda decisão judicial seria política, mas a decisão de controle de constitucionalidade seria especial, ao configurar uma legislação negativa.

como Roberto Mangabeira Unger e Kelsen (A critique of adjudication (fin de siècle), Cambridge, Massachusetts: Harvard University Press, 1997, p. 31).

${ }^{64}$ Hans Kelsen, Quien debe ser el defensor de la constitución..., ob.cit. 
Enquanto no âmbito da teoria do direito, o debate gerado pela materialização do direito desenvolveu-se em torno da distinção ou indistinção entre legislar e julgar, ele adquiriu, no campo da teoria social, contornos bem mais amplos, dando origem ao debate em torno dos paradigmas de direito responsivo e direito reflexivo. Eles representam reações opostas à materialização do direito.

O conceito de direito responsivo, que Philippe Nonet e Philip Selznick desenvolveram em seu conhecido trabalho, ${ }^{65}$ encampa com entusiasmo a finalidade no direito. Seu contexto é o impulso progressista e interdisciplinar do realismo jurídico, cujo principal objetivo era, nas palavras de Jerome Frank, citado pelos autores, tornar o direito "mais responsivo às necessidades sociais". ${ }^{66}$ Ao contrário do direito autônomo, típico do Estado de direito, caracterizado pelo insulamento e por um "formalismo cego", separado da política e guiado - numa estratégia de baixo risco - pelo procedimento e pelo respeito à lei, o direito responsivo pode resolver a tensão entre integridade e abertura ao "perceber as pressões sociais como fontes de conhecimento e de oportunidades para sua autocorreção". ${ }^{67}$ Para tanto, ele deve ser guiado pela finalidade e, numa perspectiva de alto risco, desvelar os valores implícitos nas regras jurídicas e nas políticas públicas.

A empreitada de Selznick e Nonet revela-se realmente arriscada quando eles manifestam sua discordância em relação a Dworkin, que teria, segundo eles, em artigo de $1975,{ }^{68}$ restringido o seu foco - que fora mais amplo anteriormente - à teoria da decisão judicial. Confinada nos estreitos limites do processo judicial, a distinção que Dworkin faz entre principle e policy perde seu enorme potencial de reconstrução da argumentação jurídica com vistas à adaptação do direito às necessidades sociais. Ela não pode ser aplicada, por exemplo, à forma como uma agência administrativa interpreta sua missão. ${ }^{69}$

Os próprios autores reconhecem que (i) ao enfraquecer a autoridade das regras, a finalidade amplia a discricionariedade do juiz; ${ }^{70}$ (ii) a finalidade diversifica de tal forma a

\footnotetext{
${ }^{65}$ Philippe Nonet/Philip Selznick, Law and society in transition: toward responsive law, 2nd. ed., New Brunswick: Transaction Publishers, 2001 (publicado originalmente em 1978).

66 Ibid., p. 75.

67 Ibid., p. 77.

${ }^{68}$ Ronald Dworkin, "Hard cases”, Harvard Law Review 88 (1975): 1057.

${ }^{69}$ Ibid., p. 81.

${ }^{70}$ Ibid., p. 82.
} 
racionalidade da argumentação jurídica que ela se confunde com a análise de políticas públicas, dentre outras formas de argumentação; e (iii) que existe o risco de, por ser orientado para os resultados, o direito responsivo, aberto a pragmatismo "no espírito de John Dewey”, degenerar num “'balanceamento' ad hoc de objetivos e interesses conflitantes". 71

Mesmo assim, Selznick e Nonet apostam no potencial do direito responsivo para ampliar a participação política dos cidadãos e o grau de controle democrático das autoridades públicas. Dentre outras formas, isso pode ocorrer pela reformulação do princípio da legalidade:

"O ideal de legalidade precisa ser concebido de forma mais geral, livre do formalismo. Num sistema baseado na finalidade, a legalidade significa a redução progressiva da arbitrariedade no direito positivo e na sua administração. Pressionar pela maior redução possível de arbitrariedade é demandar um sistema jurídico que seja capaz de ultrapassar as fronteiras da regularidade formal e da justiça procedimental, na direção da justiça material. Essa conquista, por sua vez, requer instituições que sejam competentes e legítimas.

"Se há uma função paradigmática do direito responsivo, é a regulação, não a atividade jurisdicional. Entendida de forma ampla, regulação é o processo de elaborar e corrigir as políticas necessárias para a realização de uma finalidade jurídica. A regulação concebida dessa forma é um mecanismo para tornar mais claro o interesse público., ${ }^{72}$ (Grifos meus).

A tensão entre abertura e integridade (ou fechamento) do direito é enfrentada de forma completamente distinta pelo paradigma do direito reflexivo. ${ }^{73}$ Ao invés de aprofundar, como fazem Selznick e Nonet, a materialização do direito, ele sugere um tipo de procedimentalização. O diagnóstico e o remédio são bastante diferentes daqueles do direito responsivo. Seu ponto de partida, além da temática weberiana sobre a materialização, é a conhecida formulação de Habermas sobre as ondas de juridificação. A terceira onda de juridificação caracteriza-se pela expansão quantitativa e qualitativa do

\footnotetext{
${ }^{71}$ Ibid., pp. 82-85.

72 Ibid., pp. 108-109.

${ }^{73}$ Cf. Gunther Teubner, "Juridification: concepts, aspects, limits, solutions", in Gunther Teubner (ed.), Juridification of social spheres: a comparative analysis in the areas of labor, corporate, antitrust and social welfare law, Berlin: Walter de Gruyter, 1987, pp. 3-48.
} 
direito no Welfare State: a burocratização do mundo, dos indivíduos e dos conflitos. Se as duas ondas anteriores ocorreram no contexto da formação do Estado moderno e da democratização do poder domado pelo constitucionalismo, a terceira fase desse movimento "constitucionalizou" o sistema econômico no contexto do Estado Social.

Não se trata, portanto, ressalta Teubner, de mera expansão quantitativa do direito. Este sofre transformações em sua função, sua forma de legitimação e sua estrutura. Em sua nova função social, o direito é instrumento de intervenção política a serviço do bem estar social. Ele promove políticas compensatórias e quebra as assimetrias de poder no mercado. É do resultado dessas intervenções que ele extrai sua legitimidade. Sua estrutura interna modifica-se significativamente. A finalidade passa a guiar o direito. A interpretação teleológica ganha terreno. Considerações de política pública e análises de custo-benefício passam a orientar as decisões dos tribunais e das agências reguladoras. A abertura do direito para a racionalidade da economia, da sociologia e da ciência política - cria uma crise de identidade do direito formal, que perde sua generalidade. A juridificação pode ser definida portanto como

\footnotetext{
"um processo no qual o Estado Social intervencionista produz um novo tipo de direito, o direito regulatório. Somente quando ambos os elementos - materialização $e$ intenção do Estado Social - são considerados conjuntamente é que podemos compreender a exata natureza do fenômeno contemporâneo da juridificação". ${ }^{74}$
}

Trata-se de uma tendência irreversível, segundo Teubner. Resta tão somente buscar soluções que amenizem as disfunções que ela traz. A argumentação de Teubner contém, entretanto, uma sutileza que é importante ressaltar. Embora ele registre que a materialização do direito contemporâneo em muito extrapola a expectativa de Weber para quem a materialização seria um fenômeno marginal -, no processo de juridificação ela se aprofunda ao mesmo tempo em que se intensifica a autonomização do direito enquanto sistema social. Em outras palavras, quanto mais materializado, mais "formalizado" torna-se o direito.

Na verdade, a teoria dos sistemas termina por substituir a tensão entre racionalidade formal e racionalidade material pelo conflito entre função e performance do direito. Ao 
reforçar sua função de estabilizar expectativas de comportamentos, o direito aprofunda sua diferenciação funcional, ou seja, torna-se autopoiético. Sua performance, ao reagir às demandas do ambiente social, desenvolve-se a partir da incorporação dos elementos externos conforme seus códigos internos, sem ferir, portanto, a autonomia do direito. Ocorre, porém, o mesmo com os demais sistemas sociais: da mesma forma que eles não podem transformar o direito, o direito não tem como transformar as instituições sociais, sob pena de se criarem disfunções, efeitos desintegradores para a área social regulada ou para o próprio direito. Essas disfunções ocorrem toda vez que se desrespeitam os limites da auto-regulação de um sistema social - verificando-se um acoplamento estrutural (structural coupling) inadequado entre o direito, a política e a área da vida social regulada. Pode ocorrer, portanto, (i) que os sistemas reajam expressando mútua indiferença; (ii) que a juridificação provoque efeitos desintegradores sobre a política ou sobre a área social regulada; ou (iii) que o direito seja exposto a pressões desintegradoras advindas da política ou do ambiente social. ${ }^{75}$

Teubner recorre várias vezes a exemplos do direito antitruste. No campo do presente trabalho, o contraste estabelecido no capítulo anterior entre a regulação financeira e o direito público brasileiro demonstra bem a indiferença resultante de um acoplamento estrutural inadequado entre o direito e o sistema econômico. Essa inadequação aparece como ameaça à economia no caso do limite constitucional dos juros: como será analisado no próximo capítulo, o Supremo Tribunal Federal, no julgamento da ADIn $n^{\circ} 4$, suspendeu os efeitos desestabilizadores do art. 192 da Constituição. Entretanto, ao fazê-lo, não poderia simplesmente negar a validade da Constituição. Terminou por encontrar no próprio código do direito uma solução formal - a necessidade de uma lei que regulamentasse o artigo - que continha os efeitos perversos da juridificação tanto para a economia quanto para o próprio direito. Já em outras ocasiões, como no caso do Fundo Garantidor de Créditos (FGC), o STF adota estratégias informais de decisão, o que revela as limitações da dogmática jurídica - que operacionaliza a diferenciação funcional do direito - para lidar com a juridificação.

${ }^{75}$ Ibid., pp. 19-27. 
"Os conceitos dogmáticos e as doutrinas", explica Tercio Sampaio Ferraz Jr., "não constituem o sistema do direito, mas dirigem-no". ${ }^{76}$ A autonomia do direito é reforçada graças à capacidade da dogmática de definir os seus próprios limites: $:^{77}$

"Para solucionar as dificuldades localizadas numa complexa ampliação do horizonte futuro, a Dogmática tem acentuado o grau de abstração da sua conceitualidade. Em outras palavras, com o aumento de incertezas, uma resposta tem sido aumentar o nível de abstração. Por exemplo: dada a injunção de novas situações ditadas pelo crescimento da intervenção do Estado no domínio econômico, a Dogmática Jurídica procura conceitos mais abertos, capazes de explicar a quebra de hierarquias normativas comum no Direito Econômico que parece revolucionar os velhos princípios da legalidade e da constitucionalidade.". 78

Entretanto, quando a quebra da hierarquia das normas é insuportável para o direito - como no caso FGC, no qual uma resolução do Conselho Monetário Nacional claramente invadiu a reserva de lei complementar -, o Tribunal vê-se na delicadíssima situação de ter de construir uma estratégia que bloqueie ou pelo menos amenize os efeitos perversos da juridificação. A juridificação reflete-se, portanto, nos casos difíceis que o STF é convocado a decidir, especialmente naqueles que envolvem a regulação financeira. Junto com ela, a indiferença mútua e os efeitos desintegradores sobre o direito, a política e o mercado financeiro constituem desafios para a atuação do Tribunal.

Esse é, portanto, o conhecido "trilema regulatório" de Teubner, uma formulação que tenta combinar as teorias de Luhmann e Habermas, ou seja, tenta estabelecer uma análise original da tensão entre abertura e fechamento do direito que combina um sentido forte de diferenciação funcional herdado da biologia com as pretensões normativas do "mundo da vida" habermasiano.

Como todo ecletismo, o trilema regulatório corre o risco de "desagradar a gregos e troianos". Em Faticidade e Validade, Habermas, ao comentar os dilemas do Welfare State, afirma:

\footnotetext{
${ }^{76}$ Tercio Sampaio Ferraz Jr., A função social da dogmática jurídica, São Paulo: Max Limonad, 1998, p. 125.

${ }^{77}$ Ibid., pp. 97-98.

${ }^{78}$ Ibid., pp. 191-192.
} 
"Este caminho [o caminho que nega a saída neoliberal mas, ao mesmo tempo, recusa o projeto do Welfare State na sua expressão atual] para a realização do sistema de direitos sob as condições de uma sociedade complexa não pode ser caracterizado de forma adequada nos termos de uma forma jurídica específica - o direito reflexivo - que seria privilegiada pelo paradigma procedimental do direito, tal como os paradigmas liberal e social favoreceram suas respectivas formas jurídicas - o direito formal e o material." ${ }^{, 79}$

De fato, um modelo de democracia deliberativa não pode aceitar a solução engendrada pelo direito reflexivo e seu programa relacional: a "regulação negociada". Teubner descarta a estratégia da desregulação como solução para a juridificação. ${ }^{80}$ Alinhase àqueles que preferem a adoção de estratégias regulatórias mais flexíveis na forma de "sistemas de negociação neocorporativista". ${ }^{81}$ Essa opção implica a troca da intervenção estatal direta (controle externo) por estruturas reflexivas internas que permitiriam às organizações - empresas, sindicatos, mídia e instituições de ensino, por exemplo desenvolver uma espécie de "consciência corporativa" que levasse em conta, nos processos decisórios da organização, os seus efeitos sociais. Um exemplo disso seria a incorporação de preocupações ecológicas por uma fábrica. ${ }^{82}$

“A criação de condições estruturais para uma 'consciência organizacional' que refletiria o equilíbrio entre a função e a performance do sistema social - este seria, em nossa definição, o papel integrador do direito reflexivo." ${ }^{\text {} 33}$

O paradigma procedimental do direito proposto por Habermas é incompatível com a regulação negociada, na medida em que ele entende que, ao engajar-se em barganhas com os subsistemas sociais, o Estado, igualando-se aos participantes das negociações, compromete sua soberania. ${ }^{84} \mathrm{~A}$ exigência normativa da gênese democrática do direito não pode ser abandonada em nome do acoplamento estrutural entre o direito e a área social

\footnotetext{
${ }^{79}$ Jürgen Habermas, Between facts and norms, ob. cit., p. 410.

${ }^{80}$ Gunther Teubner, "Juridification...", ob. cit., pp. 29-33.

${ }^{81}$ Ibid., p. 38.

82 Ibid.

${ }^{83}$ Ibid

${ }^{84}$ Jürgen Habermas, Between facts and norms, ob. cit., pp. 433-434 e 441-442.
} 
regulada. ${ }^{85}$ Da mesma forma, a relação entre direito e política não pode ser visualizada como um acoplamento estrutural operado pela constituição.

Por outro lado, Habermas não compartilha, igualmente, do entusiasmo de Selznick e Nonet quanto ao direito responsivo. A materialização total do direito, que significaria o império da finalidade, destruiria sua função de normatizar expectativas de comportamento:

\begin{abstract}
"Mesmo no Estado Social, o direito não pode ser completamente reduzido à política, se se quiser evitar a extinção da tensão interna entre faticidade e validade e, portanto, sua normatividade [...]. Os constrangimentos impostos sobre a política na forma do direito são estruturais e não, como teme o liberalismo, quantitativos.."
\end{abstract}

O paradigma procedimental da democracia deliberativa reage, portanto, à juridificação, rejeitando (i) a volta ao passado, ou seja, a reformalização do direito, a desregulação, o desmonte do aparato estatal intervencionista, a auto-restrição de um judiciário que seria somente "a boca que pronuncia a lei", um liberalismo que privilegia a igualdade formal ao mesmo tempo em que bloqueia a intervenção estatal; (ii) o

\footnotetext{
${ }^{85}$ Para uma crítica contundente, empiricamente fundamentada, à "regulação negociada", bem como às propostas de redução do controle judicial sobre a regulação, ver Susan Rose-Ackerman, "American administrative law under siege: is Germany a model?", Harvard Law Review 107 (1994): 1279-1302 (discute as perspectivas da aplicação nos E.U.A. do Negotiated Rulemaking Act, de 1990, a partir da experiência alemã, que terminou por combinar, segundo ela, o pior dos mundos: de um lado, a delegação legislativa, na prática, para grupos privados, como a "Associação Alemã de Engenheiros", e, de outro, um direito público de perfil liberal que não é capaz de exercer o controle democrático do processo administrativo normativo). No Brasil, uma visão otimista da regulação negociada, baseada na experiência norte-americana, é expressada por Sérgio Varella Bruna (Agência reguladoras: poder normativo, consulta pública, revisão judicial, São Paulo: RT, 2003, pp. 215-220). Para uma análise bem mais detalhada e uma visão cética sobre o direito reflexivo, ver José Eduardo Faria, O direito na economia globalizada, São Paulo: Malheiros, 1999, pp. 183-291. Contrastando, de uma lado, os postulados da teoria dos sistemas (Teubner, Luhmann e Wilke) e, de outro, a estrutura e a dinâmica da globalização financeira, Faria questiona: "Como foi exposto, esses teóricos afirmam que os subsistemas funcionalmente diferenciados são autônomos e que nenhum deles dispõe de condições para aspirar à direção de toda a sociedade. Com base nesses dois pressupostos, eles põem em questão as pretensões dirigistas do Estado Providência (subsistema político) e do direito social (subsistema jurídico). No entanto, o eventual triunfo do modelo do 'direito reflexivo'na prática não acabaria deixando o subsistema econômico inteiramente livre de qualquer tipo de controle, inclusive o indireto? A partir daí, em face da maximização da acumulação que constitui sua lógica e seu ethos, não acabaria esse subsistema invadindo e comprometendo a autonomia dos demais subsistemas? Além disso, ao concentrar sua atenção na continuidade de um equilíbrio quase exclusivamente fundado em soluções negociadas entre si pelas partes, na suposição de que os atores aprenderiam, com o próprio argumento dos conflitos e pelo exercício da racionalidade, que é mais sensato, mais prudente e mais 'racional' evitá-los, os teóricos do 'direito reflexivo' também parecem subestimar as possibilidades de uma 'consciência global' e de um sentido de 'responsabilidade social' num contexto econômico onde a desterritorialização da produção e os ciclos tecnológicos, sucedendo-se em ritmo cada vez mais intenso e reduzindo progressivamente o 'ciclo de rotação do capital', maximizam em termos exponenciais as condições de acumulação e acirram a competição." (p. 289).

${ }^{86}$ Jürgen Habermas, Between facts and norms, ob. cit., p. 428.
} 
aprofundamento da materialização do direito pela discricionariedade judicial ou pela regulação (entendida no sentido mais amplo de Selznick e Nonet), a manutenção ou agudização da racionalidade instrumental do Estado intervencionista, que tende a reduzir a legitimidade do direito à sua boa performance, deixando em segundo plano o sistema de direitos; (iii) o neocorporativismo reflexivo, no qual o respeito ao sistema de direitos ficaria à mercê da "consciência" das organizações, que se engajariam em barganhas com um Estado fraco, que recorre à negociação porque seus instrumentos de intervenção direta teriam se exaurido.

No plano da argumentação jurídica, Habermas, na linha de Dworkin, não aceita a idéia de discricionariedade judicial, opondo-se, portanto aos realistas e aos positivistas. ${ }^{87} \mathrm{O}$ caráter deontológico dos direitos fundamentais e dos princípios não se confundem com valores. O tribunal constitucional só pode usar uma forma de argumentação que leve isso a sério e que seja consistente, ou seja, que garanta a coerência do ordenamento jurídico. Somente assim sua atuação criadora do direito pode ser considerada legítima a partir de uma visão procedimental da constituição.

Se, no modelo liberal de democracia, o controle de constitucionalidade é visto de partida como contrário à separação dos poderes, na democracia deliberativa ele só será ilegítimo se sacrificar o respeito às condições procedimentais para a gênese democrática das leis em prol de uma pretensa ordem objetiva de valores. Em outras palavras, uma hermenêutica mais sofisticada que permita ao tribunal exercer, de certa forma, um papel criador de direito, não aprofunda a materialização deste. Pelo contrário, ela seria uma alternativa à discricionariedade judicial que levaria a uma "tirania dos valores" (Carl Schmitt). Ela somente pode ser aceita, portanto, se respeitada a exigência de que ao tribunal não é permitido argumentar em termos funcionalistas ou utilitaristas. Para garantir a racionalidade e a legitimidade de suas decisões, ele deve tratar de direitos, de normas, de princípios, e não de valores, interesses nem objetivos de política pública. ${ }^{88} \mathrm{O}$ império do direito deve prevalecer sobre o império da finalidade.

\footnotetext{
${ }^{87}$ Ibid., pp. 194-237 (Capítulo 5: "The indeterminacy of law and the rationality of adjudication").

${ }^{88}$ Ibid., pp. 238-286 (Capítulo 6: "Judiciary and legislature: on the role and legitimacy of constitutional adjudication"). Uma discussão mais profunda sobre certos temas de direito penal no Brasil desdobraria de forma sistemática a perplexidade que os alunos de direito demonstram quando, ao indagar o professor sobre certas decisões judiciais que contrariam claramente a arquitetônica do direito penal, ouvem a seguinte resposta: "a decisão logicamente correta seria 'A', mas o tribunal decidiu 'B' por uma questão de 'política criminal"”.
} 
Fica claro, assim, o modo como Habermas desenvolve um conceito de direito e um modelo de democracia distinto de Weber. Em relação ao direito, este último pode ser visto como um normativista, cujo ceticismo faz com que qualquer institucionalização de uma racionalidade moral prática seja interpretada como uma materialização do Direito. Sendo o Direito moderno essencialmente formal, associado ao tipo ideal do modo de dominação legítima legal-racional, sua materialização significaria seu enfraquecimento e, no limite, seu desmonte. Portanto, analisar decisões de controle de constitucionalidade com base na dialética weberiana entre racionalidade formal e material seria um mero exercício de constatação trágica da desestruturação do direito moderno, já que o caráter político daquele controle tem implicado, na experiência judicial do pós-guerra (nos EUA há muito mais tempo, desde Marbury v. Madison, no início do século XIX), uma materialização descontrolada do Direito, sem que este tenha sido ainda destruído.

A ambição do modelo de democracia deliberativa fundada na teoria do discurso é de oferecer critérios normativos para que o controle de constitucionalidade possa ser criticado e redirecionado para uma prática judicial que, ao buscar a garantia concomitante das autonomias pública e privada do cidadão, contribua para reduzir os efeitos perversos da juridificação do Estado Social, sem que isso implique o bloqueio da ação estatal que visa à quebra das assimetrias de poder que se escondem por trás da igualdade formal.

A inadequação da dialética weberiana para a análise do direito contemporâneo é destacada por Habermas em várias ocasiões. ${ }^{89}$ Não se deve, entretanto, reduzir a complexidade do pensamento weberiano ao positivismo jurídico. As afinidades entre as perspectivas de Kelsen e Weber não devem ser generalizadas. Elas não se verificam, por exemplo, no que se refere ao tribunal constitucional, já que, para Weber, a legislação negativa seria uma forma de materialização do direito. Uma análise mais profunda descartaria, igualmente, a aproximação entre os dois no que se refere à redução do Estado à sua dimensão jurídica, o que não estaria de acordo com o pensamento weberiano. ${ }^{90}$

\footnotetext{
${ }^{89}$ Theory of Communicative Action, v. 1, ob. cit., p. 267-270; as duas "Tanner Lectures", de 1986, reproduzidas na edição brasileira de Faktizität und Geltung (Direito e Democracia, v. 2, Rio de Janeiro: Tempo Brasileiro, 1997, pp. 193 ss).

${ }^{90} \mathrm{Cf}$. Michel Coutu, "Rationalité juridique et légitimité du droit chez Max Weber”, ob.cit., pp. 201-211.
} 
Chegamos, assim, ao ponto em que se podem resumir algumas conclusões sobre a separação dos poderes numa sociedade complexa. A constituição-máquina, trazida para o "chão normativo" da democracia deliberativa, pode ser vista como a institucionalização de um jogo de competências distribuídas entre diversos órgãos estatais. Ela não tem uma finalidade específica, ou seja, ela não é informada pelo paradigma do direito responsivo. Ela não é também vista como o acoplamento estrutural entre direito e política, como sustentariam os defensores do direito reflexivo ou da teoria dos sistemas. O seu papel é procedimental no sentido de que o jogo que ela regula deve tender a reforçar ao mesmo tempo as liberdades positivas e negativas. Não se trata mais, portanto, de desenhar ou interpretar a maquinaria constitucional de modo a produzir uma legislação moderada a la Montesquieu, mas de combinar as múltiplas faculdades de estatuir e de impedir de modo a potencializar o reforço mútuo entre a autonomia privada e a autonomia pública dos cidadãos. As faculdades são múltiplas porque agora não se trata mais de repartir a função legislativa entre o rei e o Parlamento. Nas sociedades complexas, os tribunais constitucionais e os diversos órgãos da burocracia reguladora também participam do jogo de criação das normas jurídicas, tendo, cada um deles, assim como o Executivo e o Legislativo, acesso diferente às diversas formas aceitáveis de argumentação.

Entretanto, dois últimos passos na minha argumentação são ainda necessários para que se possa iniciar, logo em seguida, a análise do controle democrático da regulação financeira em meio ao movimento da constituição-máquina.

O primeiro diz respeito a uma premissa cara ao realismo jurídico: a idéia de que “all law is judge-made law". Já vimos como o realismo de Troper leva ao extremo essa idéia, ao considerar ilegítimo o controle de constitucionalidade. Minha pretensão, aqui, é levar a sério a idéia de que o juiz, especialmente o juiz constitucional, "cria" direito, mas fazê-lo com ressalvas que garantam a legitimidade do tribunal constitucional.

A primeira ressalva é que o controle de constitucionalidade não é discricionário. Como já reforçado supra, o tribunal não pode, ao fundamentar sua decisão, argumentar como se fosse o Legislativo ou o Executivo. Ele não está autorizado nem a manipular elementos e razões fora do plano deontológico nem a decidir de forma incoerente. Um rompimento com a tradição jurisprudencial ou com cânones estabelecidos não pode ser feito sem cerimônia. Decisões ad hoc, portanto, não são aceitáveis. 
A segunda ressalva é que o juiz, ao interpretar um texto normativo, não "cria" norma ex nihilo:

“Quando refiro a 'produção' do direito pelo juiz, refiro-a em sentido diverso daquele veiculado pelo vocábulo 'criação'. Pois o que desejo afirmar é que o intérprete autêntico 'produz' direito porque necessariamente completa o trabalho do legislador (ou do autor do texto, em função regulamentar ou regimental).

"O intérprete autêntico completa o trabalho do autor do texto normativo; a finalização desse trabalho, pelo intérprete autêntico, é necessária em razão do próprio caráter da interpretação, que se expressa na produção de um novo texto sobre aquele primeiro texto."

A idéia de que o juiz completa o trabalho do legislador é rica de conseqüências para o modelo de constituição-máquina inserido numa democracia deliberativa. Vou desenvolver essa idéia para questionar se o conjunto estatuir/impedir/administrar/julgar (Montesquieu) pode ser substituído pela tríade legislar/aplicar/implementar (Habermas).

O que desejo sustentar é que, no âmbito do controle de constitucionalidade, a distinção entre legislar e julgar só pode ser mantida, em termos analíticos, se a atividade de julgar for entendida como uma modalidade especial de faculdade de impedir ou de

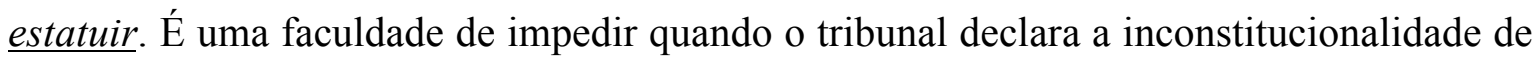
uma lei. Temos, neste caso, uma forma de veto imposta à legislação criada pelos legítimos representantes do povo. A diferença em relação ao veto presidencial é que este é lançado antes da entrada em vigor da lei. A decisão do tribunal é a expressão de uma faculdade de estatuir quando ele utiliza técnicas de decisão alternativas, que "salvam”o texto legal. É o caso, por exemplo, da interpretação conforme a constituição. É como se o tribunal estivesse emendando o texto legal, revelando o seu único sentido. A diferença em relação a uma emenda formal é que a decisão judicial não é produção de um novo texto normativo, mas da norma que resulta da interpretação do texto normativo original. O caráter especial das faculdades de estatuir e de impedir exercidas pelo tribunal reside no seu caráter nãodiscricionário ou, para seguir mais uma vez os termos de Habermas, na vedação do acesso

\footnotetext{
${ }^{91}$ Eros Roberto Grau, Ensaio e discurso sobre a interpretação/aplicação do direito, ob. cit., p. 54.
} 
do tribunal a tipos de argumentação e formas de comunicação típicas dos outros poderes morais, políticas, econômicas etc.

Sustento que essa forma de visualizar a atuação do tribunal constitucional é capaz de conciliar uma visão realista do controle judicial das leis com as exigências normativas do modelo de democracia deliberativa.

O passo final para a configuração da constituição-máquina consiste em também levar a sério uma outra idéia realista: a afirmação de Bruce Ackerman no sentido de que, embora os estudiosos do direito administrativo

\begin{abstract}
“falem bastante do 'quarto poder do Estado', não levam essa metáfora a sério o suficiente para pensar como uma constituição moderna, e não apenas leis como o Administrative Procedure Act, deveria ser elaborada de modo a insular determinadas estruturas burocráticas fundamentais em relação à intervenção ad hoc de políticos, forçando assim os políticos a concentrar suas energias nas coisas que somente eles podem legitimamente fazer numa democracia moderna: criar leis e tomar (muito poucas) decisões específicas de grande visibilidade que realmente exigem o exercício típico de estadista e de sabedoria prática." ${ }^{, 92}$
\end{abstract}

A afirmação vale não somente para a reforma das constituições, mas também para a análise e a interpretação dos textos constitucionais em vigor. Como apontado no primeiro capítulo, a indiferença em relação a essa verdade básica das democracias contemporâneas tem gerado graves conseqüências. Dentre estas, o pequeno desenvolvimento de doutrinas que busquem reconstruir a dogmática do direito público de modo a controlar a capacidade normativa de conjuntura e assegurar a sua legitimidade democrática. Conseqüentemente, a formação dos operadores do direito contribui para a reprodução de um tipo de controle judicial de índole liberal que não atende às exigências normativas de uma democracia deliberativa.

A burocracia reguladora deve ser reconhecida como um participante do jogo estabelecido pela constituição-máquina. Em outras palavras, ela também exerce uma faculdade de estatuir - a capacidade normativa de conjuntura. Essa faculdade, porém,

\footnotetext{
${ }^{92}$ Bruce Ackerman, “The new separation of powers”, ob. cit., p. 692.
} 
encontra-se submetida a três tipos de restrição: (i) ela não pode estabelecer as regras de sua própria produção, ou seja, o CMN e o $\mathrm{BCB}$ não têm competência para definir sua própria competência; (ii) ela deve estar fundamentada numa lei em sentido formal; (iii) sua legitimidade não é garantida somente pela efetividade das normas editadas, ou seja, pela capacidade dos reguladores financeiros de preservarem, de um lado, o regime monetário que garante a reprodução do regime de acumulação, e, de outro, a coesão social - ela somente será legítima se for exercida mediante um procedimento que garanta sua gênese democrática.

3. A máquina em movimento: o controle judicial da burocracia

As seguintes seqüências demonstram algumas dinâmicas da constituição-máquina brasileira, a partir do jogo de distribuição de faculdades ordinárias e especiais de estatuir $(f E)$ e de impedir $(f I)$ :

(i) Lei ordinária (LO):

Congresso elabora e aprova LO $(f E) \square$ Presidente da República veta LO $(f I) \square$ Congresso derruba o veto $(f E) \square$ LO é promulgada $\square$ minoria inconformada propõe uma ADIn $\square$ STF declara a inconstitucionalidade de LO $(f I)$

(ii) Medida provisória (MP) - primeira possibilidade:

Presidente edita MP $(f E) \square$ Congresso aprova $(f I) \square$ MP é convertida em LO $\square$ minoria inconformada propõe ADIn $\square$ STF declara a constitucionalidade de LO, mas vinculada a uma interpretação conforme a Constituição que o Tribunal formulou $(f E)$

(iii) Medida provisória (MP) - segunda possibilidade:

Presidente edita MP $(f E) \square$ Congresso rejeita MP $(f I)$

(iv) Medida provisória (MP), anteriormente à Emenda Constitucional no 32/2001:

Presidente edita MP $(f E) \square$ Congresso omite-se $(f I) \square$ Presidente pode, sucessivamente, mantida a inércia do Congresso, reeditar MP ad eternum ( $f E)$ 
(v) Lei ordinária ou complementar que atribui uma capacidade normativa de conjuntura a um órgão regulador:

Congresso elabora e aprova LO/LC $(f E) \square$ Presidente sanciona LO/LC $(f I) \square$ minoria inconformada propõe ADIn $\square$ STF declara a constitucionalidade de LO/LC (fI)

(vi) Regulamento (uma resolução do $\mathrm{CMN}-\mathrm{R}$ ):

CMN edita $\mathrm{R}(f E) \square$ partido de oposição propõe ADIn $\square$ STF declara a inconstitucionalidade de $\mathrm{R}(f)$

As hipóteses acima são meramente exemplificativas do jogo de constrangimentos e competências da constituição-máquina brasileira. A separação dos poderes torna-se ainda mais sofisticada na medida em que a Constituição de 1988 (i) estabelece, por exemplo, que são de iniciativa privativa do Presidente leis relativas a determinadas matérias, como a organização administrativa e as Forças Armadas, ${ }^{93}$ e permite a iniciativa popular, ${ }^{94}$ (ii) cria competências privativas; ${ }^{95}$ (iii) limita a delegação legislativa ao Presidente ${ }^{96}$ (iv) estabelece reserva de lei ordinária ${ }^{97}$ ou de lei complementar ${ }^{98}$ para determinadas matérias.

Entretanto, as regras constitucionais secundárias expressas não esgotam o conjunto de constrangimentos jurídicos da constituição-máquina brasileira. Elas são também o resultado da jurisprudência constitucional do STF. A cada decisão relativa a uma regra secundária específica, o Tribunal está modelando ou remodelando a cláusula pétrea constitucional da separação de poderes brasileira. Seu significado concreto é, assim, definido e redefinido cada vez que o STF decide casos difíceis que envolvem a relação entre os Poderes. A rigor, toda decisão de controle de constitucionalidade do STF tem implicações para a separação dos poderes, porque redefine as fronteiras entre as competências do Tribunal, do Executivo e do Legislativo. Em outras palavras, a especialidade das faculdades de estatuir e de impedir do Tribunal reside não somente nas

\footnotetext{
${ }^{93} \mathrm{CF} 88$, art. 61, $\S 1^{\mathrm{o}}$.

${ }^{94} \mathrm{CF} 88$, art. 61, \$2 ${ }^{\circ}$.

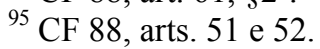

${ }^{96} \mathrm{CF} 88$, art. 68, $\S 1^{\circ}$.

${ }^{97} \mathrm{CF} 88$, art. $5^{\circ}$, XXXIX.

${ }^{98} \mathrm{CF} 88$, art. 192.
} 
formas específicas de argumentação e comunicação que ele está autorizado a utilizar - suas faculdades possuem, no jogo constitucional, a privilegiada condição de redefinir os limites das faculdades dos demais poderes e da burocracia. No julgamento da ADIn relativa ao controle externo do Judiciário do Mato Grosso, o STF, como vimos, foi além, exercendo sua faculdade de impedir em relação ao poder constituinte estadual. A visão que o Tribunal tem de si mesmo é essa: a de um Poder que em última instância controla os demais:

\begin{abstract}
"Dado que o Judiciário é, por excelência,um Poder de controle dos demais Poderes - sobretudo nos modelos positivos de unidade e universalidade da jurisdição dos Tribunais, como o nosso - parece incontestável, contudo, que a vitaliciedade ou outra forma similar de salvaguardar a permanência do Juiz na sua função será, em cada ordem jurídica considerada, marca característica da sua tradução positiva do princípio da independência dos poderes." 99
\end{abstract}

Ora, como argumentei no início deste capítulo, é o próprio Tribunal que definirá o que vem a ser a "tradução positiva do princípio da independência dos poderes". Às vezes isso é mais fácil, como no caso da vitaliciedade dos juízes, pois há uma regra constitucional expressa a respeito. É muito mais polêmico, porém, quando, na hipótese de lacunas ou antinomias, o Tribunal é obrigado a decidir de forma construtiva, como no caso do controle externo do Judiciário.

Tome-se o exemplo do mandado de injunção. ${ }^{100}$ A distorção da representação política no Brasil, um dos temas mais recorrentes nos últimos anos, foi levada ao STF pela via de um mandado de injunção impetrado por deputados e senadores do PSDB de São Paulo, elaborado por Miguel Reale Jr. ${ }^{101}$ A Constituição Federal prevê a elaboração de lei complementar ${ }^{102}$ para a diminuição da distorção da representação. Os autores pediam ao

\footnotetext{
${ }^{99}$ ADIn 98-5 - MT, Voto do Relator, Min. Sepúlveda Pertence (LEX-JSTF 237/34).

${ }^{100}$ Para uma retrospectiva da evolução do entendimento do STF a respeito do mandado de injunção, principalmente a partir do ingresso no Supremo dos ministros Marco Aurélio Mello e Carlos Velloso, ver Oscar Vilhena Vieira, Supremo Tribunal Federal: jurisprudência política, ob. cit., p. 120-133. Para uma crítica da confusão que se faz entre o mandado e a ação de inconstitucionalidade por omissão, que tem sido a posição do STF, ver José Afonso da Silva, Curso de Direito Constitucional Positivo, 14a . ed., São Paulo: Malheiros, 1997, pp. 426 e ss.

${ }^{101} \mathrm{MI} \mathrm{n}^{\mathbf{0}} 219-3$.

102 “Art. 45 A Câmara dos Deputados compõe-se de representantes do povo, eleitos pelo sistema proporcional, em cada Estado, em cada Território e no Distrito Federal.

"§ $1^{\circ} \mathrm{O}$ número total de Deputados, bem como a representação por Estado e pelo Distrito Federal, será estabelecido por lei complementar, proporcionalmente à população, procedendo-se aos ajustes necessários,
} 
STF, diante da omissão do Congresso, que não editara a referida lei, que o próprio Tribunal solucionasse o caso concreto, “determinando que o número de Deputados por São Paulo, tal como constaria, de forma indubitável, de lei, caso tivesse sido editada, seja de 70, para garantir prerrogativa inerente à soberania popular e à cidadania". ${ }^{103}$ O Supremo reconheceu a omissão do Congresso, mas limitou-se, em sua decisão, a "dar-lhe ciência dessa situação de mora constitucional para que supra a omissão em tempo útil”, frustrando a expectativa dos autores da ação e de todos que esperavam uma atuação mais incisiva da Corte.

Um outro exemplo importante foi a definição sobre o regime das medidas provisórias anteriormente à Emenda Constitucional no 32/2001. Apesar de, em decisão histórica ${ }^{104}$, o STF ter suspendido a eficácia da Medida Provisória 190 (Governo Collor) reedição da MP 189, que fora rejeitada pelo Congresso, ele não tem considerado inconstitucional a reedição de medidas provisórias que não foram rejeitadas pelo Legislativo. ${ }^{105}$ Essa distinção é fundamental. Como a Constituição não traz regras específicas a respeito da reedição, coube ao STF, guardião da Constituição, interpretar e concretizar o princípio da separação de poderes. Adotou uma posição de bloqueio, quando não permitiu a reedição de medida provisória rejeitada, mas favoreceu a intervenção do Executivo na economia, na liberdade contratual e na propriedade privada em diversos casos, ao julgar constitucional a reedição de medidas provisórias não rejeitadas afastando, assim, a tese da "rejeição tácita". ${ }^{106}$ Os críticos da decisão alertam para o perigo de o STF ter efetivamente transferido para o Executivo o poder legislativo - bastava enviar

no ano anterior às eleições, para que nenhuma daquelas unidades da Federação tenha menos de oito ou mais de setenta deputados".

${ }^{103}$ Miguel Reale Jr., Casos de Direito Constitucional, São Paulo: RT, 1992, p. 73, apud Oscar Vilhena Vieira, Supremo Tribunal Federal: jurisprudência politica, ob. cit, p. 129-130.

${ }^{104}$ Ação Direta de Inconstitucionalidade 239-7/600, apud Oscar Vilhena Vieira, Supremo Tribunal Federal: jurisprudência política, ob. cit, p. 105-109.

${ }^{105}$ Adin 1250-9/DF.

${ }^{106}$ Para uma exposição sistemática da questão das medidas provisórias, do ponto de vista da dogmática do Direito Constitucional, ver Clèmerson Merlin Clève, Atividade legislativa do Poder Executivo no Estado Contemporâneo e na Constituição de 1988, São Paulo, RT, 1993, e, principalmente, do mesmo autor, Medidas Provisórias, 2a . ed., São Paulo, Max Limonad, 1999. Para uma abordagem dos padrões de relação Executivo/Legislativo na perspectiva da Ciência Política, ver o importante trabalho de Argelina Figueiredo e Fernando Limongi, “O Congresso e as Medidas Provisórias: Abdicação ou Delegação?”, Novos Estudos Cebrap, $\mathrm{n}^{\circ}$ 47, março 1997, p. 127-154. Dos mesmos autores, ver os outros trabalhos publicados em Executivo e Legislativo na nova ordem constitucional, Rio de Janeiro, FGV/FAPESP, 1999. De consulta obrigatória também é o trabalho de Rogério Bastos Arantes, Judiciário e política no Brasil, ob. cit. Este último configura uma tentativa de análise interdisciplinar do controle de constitucionalidade exercido pelo STF. Entretanto o autor foi infeliz ao caracterizar como "administrativa" a natureza da medida provisória, reproduzindo uma equivocada doutrina jurídica (pp. 127-128). 
ao Congresso uma grande quantidade de medidas provisórias, inviabilizando seu exame e sua rejeição em tempo hábil, para que a reedição das mesmas não se submeta a qualquer tipo de controle parlamentar. Nem mesmo os requisitos constitucionais para a adoção da medida provisória - relevância e urgência, segundo o art. 62 - podem mais servir de freio ao Executivo, uma vez que o STF entende que a avaliação dos mesmos não é questão jurídica, mas sim política, devendo ser objeto de negociação entre Parlamento e Governo.

Os exemplos poderiam se multiplicar, se fossem tomados os períodos Sarney, Collor, Itamar e Fernando Henrique, não somente em relação a medidas provisórias, mas também a respeito de várias outras questões. Em todas elas, os dilemas se repetem: garantir direitos individuais ou a eficácia da política econômica; técnica de bloqueio ou permissão de intervenção; efetivamente decidir ou abdicar da decisão em favor dos agentes políticos; manifestar-se claramente ou aguardar que o sempre referido "acúmulo de processos" crie fatos consumados e a conseqüente "perda de objeto" das ações polêmicas.

No campo da delegação legislativa e do poder regulamentar, o STF igualmente tem um papel decisivo a cumprir.

A doutrina ortodoxa da separação dos poderes, com seu corolário da vedação da delegação legislativa, aparece claramente nos casos em que a legalidade absoluta está em jogo. O campo do direito tributário está repleto de exemplos, vários deles combinando a discussão da legalidade absoluta com o princípio federativo. É o que ocorre no debate sobre a guerra fiscal entre os Estados da Federação. Em dezembro de 1993, a Assembléia Legislativa do Estado do Pará aprovou uma lei que autorizava o Governador do Estado a conceder benefícios fiscais relativos ao ICMS, independentemente de deliberação do CONFAZ, sempre que entendesse necessário para "defender a Economia do Estado e a capacidade competitiva de empreendimentos locais". ${ }^{107}$ Em agosto de 1995, o STF concedeu medida liminar suspendendo a aplicabilidade da lei até o julgamento do mérito da ADIn 1.247. ${ }^{108}$ Em seu voto, o relator, Min. Celso de Mello, acusou a "inaceitável delegação legislativa" promovida pela lei, que propiciava uma "inadmissível atuação

\footnotetext{
${ }^{107}$ Lei Estadual 5.780, de 15/12/1993, art. 12.

${ }^{108}$ STF, ADIn 1.247 - PA (Medida cautelar), RTJ 168 (756-772).
} 
normativa do Poder Executivo em tema de liberalidade estatal em matéria tributária". ${ }^{109}$ A vedação da delegação legislativa vem claramente formulada:

"Não basta, portanto, que o Poder Público tenha promulgado um ato legislativo para que se legitime, desde logo, a atividade estatal. Impõe-se, antes de mais nada, que o legislador, abstendo-se de agir ultra vires, não haja excedido os limites que condicionam, no plano constitucional, o exercício de sua indisponível prerrogativa de fazer instaurar, em caráter inaugural, a ordem jurídico-normativa. Isso significa dizer que o legislador não pode abdicar de sua competência institucional para permitir que outros órgãos do Estado - como o Poder Executivo - produzam a norma que, por efeito de expressa reserva constitucional, só pode derivar de fonte parlamentar."

Ainda segundo o relator, o desrespeito do domínio normativo da lei formal levado a cabo pelo próprio legislador estadual poderia configurar uma "transgressão ao princípio nuclear da separação dos poderes."111 A referência que seu voto faz ao art. 25, I, do ADCT/88 leva adiante o argumento, ${ }^{112}$ que é completado pela afirmação peremptória de que o regulamento delegado ou autorizado não pode inovar a ordem jurídica, "mesmo que com a vontade aquiescente do legislador." ${ }^{\text {113 }}$ Essa decisão, ainda que em caráter não definitivo, é a expressão clara da versão ortodoxa das doutrinas da separação dos poderes e da vedação da delegação legislativa.

A definição de um núcleo duro da doutrina da vedação da delegação legislativa vai além dos tradicionais campos do direito tributário, do direito penal e da lei orçamentária. Um exemplo disso é o complicado debate sobre a remuneração dos agentes políticos e dos servidores dos três poderes. Em decisão liminar de setembro de 1996, ${ }^{114}$ o STF aplicou de forma literal o art. 49, VIII, da Constituição, entendendo que o Legislativo deve fixar exatamente os vencimentos do Secretário de Estado. Não pode simplesmente estipular um limite máximo para esses vencimentos, permitindo que o Governador fixe o valor exato

\footnotetext{
${ }^{109}$ Id., p. 760 (negritos no original).

${ }^{110}$ Id., p. 761 (negritos no original).

${ }^{111} \mathrm{Id} ., \mathrm{ib}$.

${ }^{112}$ Id., p. 762.

${ }^{113}$ Id., ib. (negritos no original). Dentre os trabalhos doutrinários citados pelo Relator para reforçar o papel limitado do regulamento na ordem jurídica, destaca-se o de autoria de um dos ministros do STF, Carlos Velloso - Temas de Direito Público, Belo Horizonte, Del Rey, 1994, p. 411 (id., p. 763).

${ }^{114}$ ADIn 1469 - SC - medida cautelar julgada em 12/09/1996, in RTJ 176 (591-99) (Caso Teto Salarial dos Secretários de Santa Catarina).
} 
mediante decreto. Segundo o voto do Min. Sepúlveda Pertence, "os atos de competência exclusiva do Congresso Nacional constituem a primeira hipótese de poder indelegável, ainda que formalmente, mediante delegação legislativa propriamente dita". ${ }^{115}$ Ainda segundo ele, a mera fixação de um limite configura uma "forma inequívoca de delegação". ${ }^{116}$

A leitura conjunta do art. 49, VIII, com o art. $68, \S 1^{\circ}$, da Constituição complementa, portanto, a definição do núcleo duro da doutrina da vedação da delegação legislativa.

O que esperar da atuação do STF em relação à capacidade normativa de conjuntura? Que tipo de controle poderia o Tribunal desenvolver? O próprio STF já fixou jurisprudência no sentido de que não pode ser feito o controle dos regulamentos da burocracia por meio de ADIn. Não obstante seu caráter normativo, atos como resoluções, instruções e portarias são entendidos como secundários em função das leis e medidas provisórias às quais eles dariam execução. Sobre eles deve ser exercido um controle de legalidade, e não de constitucionalidade. ${ }^{117}$ Entretanto, quando o regulamento tem característica de ato normativo autônomo, ou seja, quando não foi editado com base em lei específica, ele pode ser atacado por meio da ADIn. ${ }^{118}$

O reconhecimento do caráter normativo desses atos, por si só, já é algo relevante, mesmo que não haja uma decisão de mérito do STF. Um excelente "teste" processual do caráter normativo de uma resolução do CMN consiste na aplicabilidade da súmula 266 do STF, segundo a qual "não cabe mandado de segurança contra lei em tese". Em junho de 1987, uma resolução estabeleceu a OTN como referência para a atualização dos saldos da caderneta de poupança, do FGTS e do PIS/PASEP. Em decisão de 1990 envolvendo a matéria, ${ }^{119}$ o STF entendeu que o item III da Resolução 1.338 do $\mathrm{CMN}^{120}$ tinha caráter de

\footnotetext{
${ }^{115}$ Id., p. 599.

${ }^{116}$ Id., ib.

117 ADIn 311-9 - DF; ADIn 365-8 (AgRg); ADIn 531-DF (AgRg); ADIn 536-7-DF; ADIn 418-DF (Medida liminar) - relativa à Resolução $1679 / 1990$ do $\mathrm{CMN}$, que estabelecia normas para a intermediação das sociedades corretoras nas operações de câmbio); ADIn 1.827-SP - relativa à Resolução 61/1998 da Agência Nacional de Energia Elétrica - (ANEEL).

${ }^{118}$ ADIn 1.590 - SP; ADIn 1.396 - SC.

119 STF, Recurso em Mandado de Segurança 21.123 - RJ, in RTJ 134 (159-168), julgado em 25 de outubro de 1990 .
} 
"norma em tese" "121, não sendo, portanto, o mandado de segurança, o instrumento mais adequado para atacá-la. Os votos dos ministros foram claros e sintéticos, não tendo havido debate sobre aquele caráter normativo. A única ressalva em sentido contrário foi o voto do Min. Marco Aurelio. ${ }^{122}$

Um segundo teste processual seria a possibilidade de se impetrar um mandado de injunção contra uma autoridade monetária. A hipótese é singular: um cidadão que exigiria do $\mathrm{BCB}$ ou do $\mathrm{CMN}$ uma norma regulamentadora indispensável para o exercício de direitos constitucionais. Esse curioso exercício de cidadania não configura mera hipótese. Em outubro de 1998 o STF decidiu sobre o Mandado de Injunção 571-SP, cuja impetrante afirmava que as normas do BCB vinham “desconsiderando a sua obrigação básica de regulamentar e disciplinar os custos financeiros conforme o preceito constitucional claro e categórico do Artigo $192 \S 3^{\circ}$ da nossa Carta Magna [... $]^{123}$ - em outras palavras, a impetrante exigia que o $\mathrm{BCB}$ exercesse seu poder normativo para fazer cumprir o limite constitucional de $12 \%$ dos juros reais. Seria muito interessante saber a posição do STF a respeito desse caso. Entretanto, o Tribunal tratou apenas do aspecto processual e, em decisão unânime, declinou de sua competência para a Justiça Federal de primeira instância de São Paulo. O caso voltou então para a $10^{\mathrm{a}}$ Vara daquela Justiça. A relevância do caso é clara: somente se pode admitir mandado de injunção contra o CMN ou o BCB se é aceito o caráter normativo de suas competências.

Que feições podem assumir, nessa concretização da Constituição, as competências dos conselhos e agências do Executivo? Particularmente no âmbito do sistema financeiro nacional, como a racionalidade que rege a manutenção da estabilidade do sistema condiciona as categorias e os esquemas interpretativos do Direito Público? O CMN e o BACEN estão efetivamente legislando? Qual a reação do STF à pretensão de validade jurídica e de legitimidade das medidas econômicas?

No próximo capítulo, essas questões serão abordadas a partir da análise de casos exemplares da jurisprudência constitucional do STF.

\footnotetext{
${ }^{120}$ Resolução 1.338 do CMN, de 15/06/1987: "III - Os saldos das cadernetas de poupança, bem como os do Fundo de Garantia de Tempo de Serviço (FGTS) e do Fundo de Participações PIS/PASEP, serão atualizados, no mês de julho de 1987, pelo mesmo índice de variação do valor nominal da OTN."

${ }^{121}$ Id., voto do relator, Min. Moreira Alves, p. 167.

${ }^{122}$ Voto vencido, o Min. Marco Aurélio sustentava o caráter concreto da resolução (id. ib.).

${ }^{123}$ M.I. 571-SP, in RTJ 168, p.46.
} 


\section{CAPÍTULO III ESTUDO DE CASOS}

1. Quatro dificuldades para a análise da jurisprudência constitucional no Brasil

O estudo das decisões do STF impõe desafios diretamente proporcionais ao fascínio que seus julgados despertam. Quatro deles serão aqui brevemente apresentados, sem a pretensão de resolvê-los. Trata-se apenas de um registro que deixa claras as limitações do presente trabalho e de toda e qualquer pesquisa sobre a jurisprudência constitucional no Brasil. Cumpre delimitá-las e atacá-las com ousadia, correndo o risco do insucesso. Esses desafios não podem ser satisfatoriamente enfrentados por nenhuma tese isolada - consubstanciam, antes, pedaços de uma gigantesca tarefa de toda uma geração de pesquisadores que leve a sério a análise realista de decisões judiciais.

À medida em que são abordados, esses problemas revelam-se não somente obstáculos para a compreensão da atuação do STF, mas dificuldades que se põem para que o próprio Tribunal consolide sua jurisprudência. Não são somente quebra-cabeças metodológicos, mas também desafios para a democracia brasileira.

A primeira dificuldade é a mais óbvia de todas: a descomunal quantidade de ações já julgadas e pendentes de julgamento pelo STF, efeito provocado pelo seguinte conjunto de fatores: (i) o caráter híbrido do modelo brasileiro de controle descentralizado de constitucionalidade, que combina as técnicas de controle incidenter e de controle principaliter; ${ }^{1}$ (ii) a inexistência de mecanismos de triagem dos casos mais relevantes e de

\footnotetext{
${ }^{1}$ Adoto aqui a terminologia do Direito Comparado, seguindo o trabalho de Mauro Cappelletti e William Cohen, Comparative Constitutional Law: cases and materials, Charlottesville, Virginia: The Michie Company, 1979, pp. 3-112). Os tipos ideais de controle de constitucionalidade são: (i) modelo centralizado: criado pela Suprema Corte dos E.U.A., a partir de Marbury v. Madison (1803), permite o judicial review incidenter - não contempla, portanto, a possibilidade de controle via ação direta - por todos os juízes e tribunais, mas garante a segurança jurídica mediante um mecanismo de uniformização jurisprudencial - 0 stare decisis; (ii) modelo centralizado: é o modelo austríaco, formulado por Kelsen para a Constituição de outubro de 1920 da Áustria, que só permite o controle feito via ação direta que só pode ser apreciada por uma corte criada para essa finalidade específica. O Brasil adotou claramente uma mistura - infeliz - dos dois modelos. O caráter híbrido de um sistema de controle de constitucionalidade não é um mal per se, o que é demonstrado pelo modelo alemão. O problema é como a mistura de elementos é feita. O direito comparado
} 
desestímulo a recursos procrastinatórios - interpostos inclusive pelo próprio Poder Público - ou ações diretas irrelevantes; (iii) a inexistência de um mecanismo análogo ao stare decisis do direto anglo-saxônico, o que leva o STF a julgar as mesmas questões de inconstitucionalidade inúmeras vezes; e (iv) o acúmulo de competências que nada têm a ver com controle de constitucionalidade, como homologação de sentenças estrangeiras, concessão do exequatur às cartas rogatórias, além de várias hipóteses de habeas corpus e mandados de segurança. ${ }^{2}$

Dado o tradicional desprezo que a pesquisa e o ensino do direito no Brasil nutrem pelo estudo detalhado de casos - geralmente lêm-se somente as ementas -, essa enorme

(Cappelletti \& Cohen, ob. cit.) tem mostrado claramente isso e alertado - sem referência ao caso brasileiro para os riscos de combinações infelizes. O trecho transcrito a seguir é longo, mas importantíssimo para registrar esse alerta clarividente do direito comparado - os problemas descritos são exatamente os que verificamos no Brasil pós-88: "Although judicial decisions in civil law countries are important informal sources of law, the principle of stare decisis is foreign to civil law judges. A system which allowed each judge to decide on the constitutionality of statutes could therefore result in a law being disregarded as unconstitutional by some judges, while being held constitutional and applied by others. Furthermore, the same judicial organ, which had one day disregarded a given law, might uphold it the next day, having changed its mind about the law's constitutional legitimacy. Differences could arise between judicial bodies of different type or degree, for example between ordinary courts and administrative tribunals, or between the younger, more radical judges of the inferior courts and the older, more tradition counscious judges of the higher courts. This is notoriously what happened in Italy from 1948 to 1956 and what continues to happen on a large scale in Japan. The extremely dangerous result could be a serious conflict between the judicial organs and grave uncertainty as to the law. Moreover, even though a given law has been held unconstitutional with regard to one party, nevertheless other affected parties would have to raise the issue of constitutionality de novo." (Cappelletti \& Cohen, ob. cit., pp. 78-79). Os autores prosseguem com um exemplo do direito tributário no Japão: "A plaintiff files suit claiming that a certain tax law is unconstitutional and obtains a judgement to that effect; but, the writer continues, 'according to the individual-effect theory, the law per se remains in force and binding on taxation offices'. As a result, every other interested party must initiate a separate action to scape the effects of the law." (p. 79). A solução para contornar a inexistência da noção de stare decisis nos países que importaram o modelo norte-americano de judicial review seria criar um substituto adequado para a Suprema Corte americana, "a judicial body capable of giving decisions of general binding effect in cases dealing with the constitutionality of legislation. It was hoped that such special bodies could avoid the conflicts and chaotic uncertainties of which we have spoken above." (p. 79, grifos meus). Como é sabido, o modelo desenhado pela Constituição de 1988 não foi capaz de lidar com esses problemas. Radicalizados pela dinâmica da delicada governabilidade brasileira em meio à instabilidade econômica que se seguiu à redemocratização do País, aqueles problemas engendraram a confusa solução - criticada como autoritária - trazida pela Emenda Constitucional no 3/93: a criação da ação direta de constitucionalidade (ADC) e a restrição do rol de legitimados ativos para proposição da argüição de descumprimento de preceito fundamental - inovações a serem comentadas nos próximos parágrafos. Para aumentar a confusão e a crítica, o atual projeto de reforma do Judiciário contempla a criação da "súmula vinculante".

${ }^{2}$ Cf. Luís Roberto Barroso, "Dez anos da Constituição de 1988 (Foi bom pra você também?)", in: Margarida Maria Lacombe Camargo (org.), 1988-1998: uma década de Constituição, Rio de Janeiro: Renovar, 1999, p. 56; Keith Rosenn, "Judicial review in Brazil: developments under the 1988 Constitution", Southwestern Journal of Law and Trade in the Americas 7 (2000), pp. 291-319. Para um comentário recente na mídia, em defesa da redução da carga de trabalho do STF por meio da criação de um mecanismo de triagem, ver Joaquim Falcão, "Repercussão geral", Folha de São Paulo, 18.04.2004, p. A-3. 
massa de julgados não levou a uma produção acadêmica intensa que a organizasse. ${ }^{3}$ Por outro lado, o excesso de trabalho não permite aos Ministros, na elaboração de votos, a sofisticação e a sistematicidade que garantiriam ou uma integração rigorosa aos precedentes e aos princípios jurídicos do direito brasileiro - coerência - ou um rompimento criterioso e fundamentado com a tradição.

A segunda dificuldade está intimamente relacionada à primeira, com ela compartilhando uma de suas causas: a inexistência, no sistema brasileiro de controle de constitucionalidade, do mecanismo do stare decisis. Isso implica não fazer sentido, em princípio, no Brasil, a noção de leading case. A imitação republicana parcial das instituições norte-americanas criou, portanto, no País, um sistema descentralizado de controle de constitucionalidade, desprovido de um mecanismo de sedimentação e uniformização jurisprudencial. Mesmo após a criação do controle abstrato (principaliter), com a implantação da representação por inconstitucionalidade - em 1965, num contexto e numa forma autoritários -, das ações diretas de inconstitucionalidade (1988) e de constitucionalidade (1993) e da argüição de descumprimento de preceito fundamental (1988, alterada em 1993, e regulamentada em 1999, pela mesma lei que tratou da ADIN e da ADC), o resultado tem sido a dificuldade de harmonização da jurisprudência do STF em algumas matérias e a harmonização da jurisprudência no País como um todo. Tome-se o exemplo do limite constitucional dos juros reais, em vigor antes da Emenda Constitucional n ${ }^{\mathrm{o}}$ 40: mesmo após a decisão do STF na ADIn 4, ${ }^{4}$ várias decisões judiciais, principalmente no Rio Grande do Sul, continuaram declarando a auto-aplicabilidade do art. $192, \S 3^{\circ}$ da $\mathrm{CF}$, que estipulava a limitação em $12 \%$ ao ano. O resultado disso tudo é caótico, como já previam Mauro Cappelletti e William Cohen, ao chamar a atenção para a importação parcial do sistema descentralizado norte-americano. Trata-se, porém, de questão polêmica no Brasil: a oposição - com destaque para a classe dos advogados - a um mecanismo forte de uniformização de jurisprudência baseia-se no argumento de que ele engessaria a jurisprudência e seria autoritário.

\footnotetext{
${ }^{3}$ Deve-se registrar aqui, entretanto, o conhecido trabalho de de Lêda Boechat Rodrigues, (História do Supremo Tribunal Federal, em seus vários volumes, publicados pela Ed. Civilização Brasileira). Ver também, Oscar Vilhena Vieira, A Constituição e sua reserva de justiça: um ensaio sobre os limites materiais ao poder de reforma, São Paulo: Malheiros, 1999; Virgílio Afonso da Silva, "O proporcional e o razoável”, Revista dos Tribunais 798 (2002), pp. 23-50. No âmbito do ensino jurídico, deve-se destacar o trabalho de Carlos Ari Sundfeld, que há alguns anos desenvolve com seus alunos da Pontifícia Universidade Católica de São Paulo (PUC-SP) e da Sociedade Brasileira de Direito Público (SBDP) estudos de jurisprudência.

${ }^{4}$ Analisada infra.
} 
O sistema brasileiro já é por demais complexo, por combinar os modelos centralizado e descentralizado e as técnicas de controle incidenter e principaliter. Além disso, questões relativas aos efeitos da declaração de inconstitucionalidade sempre foram polêmicas, nunca tendo sido tratadas expressamente pela Constituição. São questões inerentes ao próprio controle de constitucionalidade, que têm sido enfrentadas de diversas formas na experiência internacional. Destacam-se dentre essas questões as referentes (i) à nulidade/anulabilidade da lei ou do ato normativo - efeitos ex nunclex tunc da medida liminar e da decisão final de mérito; (ii) à repristinação da legislação anterior àquela declarada inconstitucional; (iii) à interpretação conforme a Constituição/declaração de nulidade sem redução de texto e demais técnicas alternativas de decisão, vis-à-vis os limites da coisa julgada. Apesar disso, algumas dessas questões foram resolvidas pela jurisprudência do STF. ${ }^{5}$

Em 1993, como já referido, o sistema ficou ainda mais complicado, com a criação, pela Emenda Constitucional $n^{\circ} 3$, da "ação declaratória de constitucionalidade de lei ou ato normativo federal" (ADC), com "eficácia contra todos e efeito vinculante, relativamente aos demais órgãos do Poder Judiciário e ao Poder Executivo". 6

Em novembro de 1999, foi promulgada lei ${ }^{7}$ que detalhou os aspectos processuais da ADIn e da ADC, estabelecendo, dentre outras regras, que (i) a medida cautelar em ADIn será concedida com efeito ex nunc, salvo entendimento contrário do STF ${ }^{8}$ (ii) a concessão da medida cautelar em ADIn torna aplicável a legislação anterior, caso ela exista, salvo

\footnotetext{
5 Para um balanço dessas questões, ver Clèmerson Merlin Clève, A fiscalização abstrata de constitucionalidade no direito brasileiro, $2^{\mathrm{a}}$. ed., São Paulo: RT, 2000, pp. 241-270. Luís Roberto Barroso sintetiza a jurisprudência do STF a respeito: (i) "a decisão que pronuncia a inconstitucionalidade de uma norma tem caráter declaratório e produz efeitos retroativos"; (ii) "não cabe ação direta contra atos normativos secundários, como decretos regulamentares, instruções normativas resoluções etc."; (iii) "cabe ação direta contra regulamento autônomo, isto é, a quele que não visa a regulamentar uma lei, para o fim de verificar se não houve ofensa ao princípio constitucional da reserva legal"; (iv) "declaração de inconstitucionalidade é competência privativa do Poder Judiciário. Não cabe declaração de inconstitucionalidade de lei ou ato normativo feita por lei"; (v) "não cabe ação direta contra leis anteriores à Constituição"; (vi) revogada a lei argüida de inconstitucional, a ação direta perde o objeto"; (vii) "não cabe ação direta contrapondo lei municipal à Constituição Federal"; (viii) "a declaração de inconstitucionalidade de uma lei restaura a eficácia de norma que haja sido por ela afetada", "Dez anos da Constituição de 1988 (Foi bom pra você também?)", ob. cit., pp. 59-60.

${ }^{6} \mathrm{CF} 88$, art. 102, I, “a” c/c $\S 2^{\circ}$.

${ }^{7}$ Lei 9.868 , de 10 de novembro de 1999.

${ }^{8}$ Lei $9.868 / 99$, art. $11, \S 1^{\circ}$.
} 
expressa manifestação em contrário do Tribunal; ${ }^{9}$ (iii) a concessão de medida cautelar em ADC implica que todos os juízes e Tribunais suspendam o julgamento dos processos que envolvam a aplicação da lei ou do ato normativo objeto da ação até seu julgamento definitivo; ${ }^{10}$ (iv) "a declaração de constitucionalidade ou de inconstitucionalidade, inclusive a interpretação conforme a Constituição e a declaração parcial de inconstitucionalidade sem redução de texto, têm eficácia contra todos e efeito vinculante em relação aos órgãos do Poder Judiciário e à Administração Pública federal, estadual e municipal". ${ }^{11}$

Essa nova lei também consagrou aquilo que foi denominado de "caráter dúplice ou ambivalente" de ambas as ações, que estende à ação declaratória as regras de admissibilidade e de procedimento aplicáveis à ação direta:" "proclamada a constitucionalidade, julgar-se-á improcedente a ação direta ou procedente eventual ação declaratória; e, proclamada a inconstitucionalidade, julgar-se-á procedente a ação direta ou improcedente eventual ação declaratória".13

Esse caráter dúplice, o efeito vinculante e a própria criação da ADC - com seu restrito rol de legitimados ativos ${ }^{14}$ - foram e continuam sendo objeto de críticas contundentes, ${ }^{15}$ de acordo com as quais (i) a introdução da ADC no sistema brasileiro, como uma ação contrária à ADIn, com tão poucos legitimados ativos, neutralizou os ganhos democráticos do sistema de controle de constitucionalidade obtidos com a Constituição de 1988; (ii) a Constituição não define o que seria o efeito vinculante, que tem sido explicado pela doutrina que lhe é favorável de forma pouco convincente, como uma importação de um instituto do direito alemão que confere força vinculante aos fundamentos da decisão do Tribunal Constitucional; (iii) a lei brasileira determina

\footnotetext{
${ }^{9}$ Lei $9.868 / 99$, art. $11, \S 2^{\circ}$.

${ }^{10}$ Lei 9.868/99, art. 21, caput.

${ }^{11}$ Lei 9.868/99, art. 27.

${ }^{12}$ Cf. Gilmar Ferreira Mendes, "Lei 9868/99: processo e julgamento da ação direta de inconstitucionalidade e da ação declaratória de constitucionalidade perante o Supremo Tribunal Federal", Jus Navigandi 41, Teresina, 2000. Disponível [on-line] in: http://www1.jus.com.br/doutrina/texto.asp?id=130 [29-01-2004].

${ }^{13}$ Lei 9.868/99, art. 24.

${ }^{14}$ Somente o Presidente da República, as Mesas do Senado e da Câmara e o Procurador-Geral da República (CF 88, art. 103, § $4^{\circ}$ ).

${ }^{15}$ Reproduzo, aqui, algumas das críticas representativas do debate que se instalou no Brasil, conforme o contundente artigo de José Ignacio Botelho de Mesquita, "O desmantelamento do sistema brasileiro de controle de constitucionalidade", Revista da Pós-Graduação da Faculdade de Direito da Universidade de São Paulo 5 (2002), pp. 9-19.
} 
expressamente que os motivos da decisão não fazem coisa julgada ${ }^{16}$ e, sendo essa a tradição em nosso direito, não faz sentido interpretar a Constituição com base na lei alemã; (iv) ao contrário dos que defendem a importação do efeito vinculante, no próprio direito alemão, que distingue efeito vinculante (Bindungswirkung) de força de lei (Gesetezeskraft), "não se mostra correto o entendimento de que o efeito vinculante teria por objetivo estender à motivação o efeito vinculante da parte dispositiva da sentença" ${ }^{17}$

A crítica vai ainda mais além, alcançando outra inovação da Emenda Constitucional $n^{\circ}$ 3/93: a restrição do rol de legitimados ativos para proposição da argüição de descumprimento de preceito fundamental. ${ }^{18}$ Ao contrário das expectativas criadas, ela não teria trazido para o Brasil a Reclamação Constitucional (Verfassungsbschwerde) do direito alemão. Esta pode ser proposta por qualquer pessoa, enquanto seu falso sucedâneo brasileiro, de acordo com a lei que o regulamentou, tem como legitimados ativos apenas aqueles mesmos da ADIn - o que seria mais uma demonstração de como "o autoritarismo ascendente vem ganhando terreno no Direito Processual, à custa da subtração sistemática dos meios e recursos constitucionalmente assegurados para garantir o respeito aos direitos e às liberdades fundamentais". ${ }^{19}$

Considerando-se o caráter recente de todas essas inovações e a tão acirrada disputa doutrinária, torna-se difícil (i) pensar o conceito de leading case no direito brasileiro e (ii) entender o conceito de leading case que o próprio STF tem utilizado. A expressão foi usada pelo Min. Celso de Mello em seu voto num caso que tratava de matéria sobre a qual o STF já havia firmado um "entendimento jurisprudencial prevalecente": ${ }^{20}$ a constitucionalidade da taxa de fiscalização dos mercados de títulos e valores mobiliários. A expressão tem aparecido desde então em várias ementas de decisões do Tribunal. ${ }^{21}$ Sempre

\footnotetext{
${ }^{16}$ Código de Processo Civil, art. 469, I.

${ }^{17} \mathrm{Cf}$. José Ignacio Botelho de Mesquita, ob. cit., p. 15.

${ }^{18} \mathrm{CF} 102, \S 1^{\mathrm{o}}$. Foi regulamentada pela Lei 9.882, de 03 de dezembro de 1999.

${ }^{19}$ Cf. José Ignacio Botelho de Mesquita, ob. cit., p. 19.

${ }^{20}$ Supremo Tribunal Federal, RE 216.259-1 (AgRg) - CE, Relator Min. Celso de Mello, publ. D.J. 19.05.2000, Ementário 1991-2. Disponível [on-line] in (www.stf.gov.br). A taxa fora criada pela Lei $7.940 / 89$.

${ }^{21}$ Supremo Tribunal Federal, RE 328.646-3 (AgRg) - PR (2002); RE 316.929 (AgRg) - DF (2002); RE 296.813 (AgRg) - MG (2002); RE 400.869 (AgRg) - DF; RE 293.970 (AgRg) - DF (2002); RE 384.121 (AgRg) - PR (2002); RE $311.287(\mathrm{AgRg})$ - SC (2002); RE 348.352 (AgRg) - SC ; RE 330.498 (AgRg) SC; RE 366.133 (AgRg) - RS; RE 371.018 (AgRg) - PR; RE 389.910 (AgRg) - DF; RE 382.064 (AgRg) RJ; RE 348.158 (AgRg) - SP; RE 252.798 (AgRg) - BA (2002); Inq 1720 (QO) - RJ (2001). Pesquisa realizada utilizando o mecanismo de busca do website do STF acusou um único caso anterior à Emenda
} 
são referidos o Regimento Interno do $\mathrm{STF}^{22}$ e a Lei $8038 / 90^{23}$ para fundamentar a atribuição do relator para negar seguimento a pedidos ou recursos que tratem de matéria já abordada em um leading case, ainda que este não tenha sido publicado ou transitado em julgado. A noção de leading case parece, portanto, ter sido efetivamente adotada pelo Tribunal após a criação do efeito vinculante pela Emenda Constitucional $n^{\circ} 3$ - para a ADC - e sua extensão à ADIn, realizada pela Lei 9.868/99. Entretanto, associada ao detalhe processual do art. 101 do Regimento Interno do STF, relativo aos poderes do relator, essa noção de leading case é claramente insatisfatória para esclarecer e concretizar a idéia mais ampla de efeito vinculante introduzida recentemente no direito brasileiro.

A terceira grande dificuldade consiste num problema de direito intertemporal. A alternância entre regimes democráticos e autoritários e a impressionante marca de sete constituições republicanas são fatos que não permitiram ao STF realizar a sedimentação jurisprudencial relativa à separação dos poderes e ao controle do poder normativo da burocracia. Há pelo menos duas razões importantes para essa afirmação.

A primeira razão, mais claramente perceptível, diz respeito ao fato de que a jurisprudência constitucional é construída como interpretação de uma determinada constituição. Se muda a ordem constitucional, duas conseqüências se seguem: (i) uma nova jurisprudência deve ser desenvolvida; (ii) a "velha" jurisprudência, a jurisprudência enraizada na constituição revogada, pode ser aproveitada, desde que submetida ao teste de recepção pela nova constituição. Assim, chega-se à seguinte constatação: o teste de recepção só pode ser feito por decisões reiteradas do STF, ou seja, por uma jurisprudência "nova". Dessa forma, a jurisprudência "velha" só se torna compatível com a nova ordem constitucional na medida em que o Tribunal a transforma em jurisprudência nova, o que nos leva ao ponto de partida do raciocínio.

Constitucional no 3 em que a expressão aparece: o RE 76.210 - SP (1974), relatado pelo Min. Leitão de Abreu. Curiosamente, entretanto, em nenhum momento em seu voto o ministro utiliza a expressão leading case. Ela aparece tão somente na ementa.

${ }^{22}$ Regimento Interno do STF, art. 101: "A declaração de constitucionalidade ou inconstitucionalidade de lei ou ato normativo, pronunciada por maioria qualificada, aplica-se aos novos feitos submetidos às Turmas ou ao Plenário, salvo o disposto no art. 103". De acordo com o art. 103, “qualquer dos Ministros pode propor a revisão da jurisprudência assentada em matéria constitucional e da compendiada na Súmula, procedendo-se ao sobrestamento do feito, se necessário".

${ }^{23}$ Lei 8.038/90, art. 38: "O relator, no Supremo Tribunal Federal [...], decidirá o pedido ou o recurso que haja perdido seu objeto, bem como negará seguimento a pedido ou recurso manifestamente intempestivo, incabível ou improcedente ou, ainda, que contrariar, nas questões predominantemente de direito, Súmula do respectivo Tribunal". 
A segunda razão diz respeito à natureza do regime político. No caso brasileiro, até que ponto a jurisprudência sobre delegação legislativa, desenvolvida durante o período da ditadura militar, pode ser aproveitada pelo STF do Brasil redemocratizado, se, durante aquele tempo, tivemos um regime no qual a separação de poderes era mitigada, inclusive, pelo afastamento compulsório dos Ministros Hermes Lima, Victor Nunes Leal e Evandro Lins e Silva? Admitindo-se a recepção de jurisprudência enraizada em textos constitucionais revogados, não seria muito mais coerente com a Constituição de $88^{24}$ e com o regime democrático retomar ou recepcionar, no que fosse cabível, a jurisprudência relativa à Constituição de $1946 ?$

Desprezar essas questões seria acreditar - de forma idealista - numa evolução linear da jurisprudência constitucional no Brasil, como se desde 1891 nada de extraordinário tivesse acontecido no País, ou como se as decisões do STF pairassem intactas por sobre o processo político brasileiro.

Finalmente, a quarta grande dificuldade para o estudo da jurisprudência constitucional brasileira diz respeito às estratégias informais de decisão do STF nos casos em que uma decisão final de mérito poderia provocar amplas conseqüências políticas ou econômicas negativas. A história da evolução das técnicas de controle de constitucionalidade demonstra como foram surgindo mecanismos formais de manipulação dos efeitos da declaração de inconstitucionalidade a partir da necessidade prática de viabilizar decisões finais de mérito sem que essa decisão acarretasse graves inconvenientes, como os problemas do vazio legislativo ou da inconstitucionalidade mais

\footnotetext{
${ }^{24}$ Somam-se a essas questões uma outra, relacionada à legitimidade do STF e à expectativa de mudança na sua jurisprudência: "O constituinte de 1988 tomou, sem maior debate político, a decisão grave de manter como integrantes do STF todos os ministros que haviam sido investidos no Tribunal pelos governos anteriores. Vale dizer: sem embargo da inegável virtude pessoal e intelectual de muitos dos juízes que lá tinham assento, a corte constitucional brasileira, encarregada de interpretar a nova Carta, era composta de juristas cuja nomeação era lançada a crédito do regime militar. Sem dever o seu título de investidura à nova ordem, e sem qualquer compromisso político com a transformação institucional que se operara no país, a Corte reeditou burocraticamente parte da jurisprudência anterior, bem como alimentou inequívoca má vontade para com algumas inovações. Não se escapou, aqui, de uma das patologias crônicas da hermenêutica constitucional brasileira, que é a interpretação retrospectiva, pela qual se procura interpretar o texto novo de maneira a que ele não inove nada, mas, ao revés, fique tão parecido quanto possível com o antigo" (Luís Roberto Barroso, "Dez anos da Constituição de 1988 (Foi bom pra você também?)", ob. cit., p. 55). Isso implicaria, certamente, uma discussão profunda sobre a "recepção" das súmulas do STF pela nova Constituição, o que extrapolaria os objetivos do presente trabalho.
} 
grave da norma reentrante. Exemplos dessa tendência são a decisione manipolative do Tribunal Constitucional italiano e a simples declaração da incompatibilidade da norma com a Constituição sem a pronúncia de sua nulidade pelo Tribunal Constitucional alemão. $^{25}$

Uma dessas técnicas já faz parte do direito brasileiro: a interpretação conforme a Constituição. Entretanto, o que se verifica também em importantes casos julgados pelo STF é a adoção de uma estratégia informal de decisão: o adiamento de decisões finais de mérito, com ou sem a tematização obiter dictum da inconstitucionalidade não declarada mas sinalizada, até que se consume ou se acomode uma situação de fato que faça a ação perder seu objeto. Este último é o que se verificou no julgamento da liminar do caso FGC analisado logo abaixo -, em que se discutiu a hierarquia entre lei complementar e resolução do CMN. Como essa estratégia informal via de regra leva ao arquivamento da ação, ela permite ao STF resolver casos difíceis sem criar precedentes que comprometeriam a coerência da ordem jurídica e da jurisprudência do Tribunal.

Com a consciência dessas quatro dificuldades metodológicas - o grande número de decisões a serem pesquisadas e analisadas, a ambigüidade da idéia de leading case no sistema brasileiro, a alternância de regimes políticos e as estratégias informais de decisão -, pode-se iniciar o estudo de casos exemplares do STF. Os casos analisados a seguir não podem ser considerados, a rigor, pelos motivos já expostos, leading cases. Alguns deles nem sequer chegaram a ter uma decisão de mérito, tendo sido arquivados por perda superveniente de objeto. Outros são anteriores à Constituição de 1988. Entretanto, o que justifica seu estudo, além da importância intrínseca das questões suscitadas, é o caráter exemplar com o que ilustram a atuação do STF em meio a três temas fundamentais para o presente trabalho: (i) o modo como o Tribunal processa a tensão entre a racionalidade formal e a racionalidade material, tensão essa tematizada no capítulo anterior, em meio à discussão sobre a juridificação das esferas sociais; (ii) a reação do STF ao agigantamento dos poderes normativos da burocracia que regula o mercado financeiro; (iii) a reação do STF à demanda por maior participação democrática no processo decisório da regulação financeira.

${ }^{25}$ Cf. Clèmerson Merlin Clève, A fiscalização abstrata da constitucionalidade no direito brasileiro, ob. cit., pp. 260-261. 
2. A tensão entre racionalidades

O Fundo Garantidor de Créditos (FGC) foi um mecanismo criado no contexto da crise bancária brasileira de 1995. O Banco Central o define da seguinte forma:

“[...] [É] uma associação civil sem fins lucrativos, com prazo indeterminado de duração e constituído sob a forma de sociedade de direito privado, tendo por objetivo dar cobertura, de até $\mathrm{R} \$ 20$ mil por titular, a depósitos e aplicações nas hipóteses de decretação de intervenção, liquidação extrajudicial ou falência de instituição que participe do referido fundo, ou, ainda, de reconhecimento, pelo Banco Central, de estado de insolvência da instituição que, nos termos da legislação vigente, não esteja sujeita aos regimes acima mencionados”, ${ }^{26}$

Ainda segundo o BCB, "a proteção de até R \$ 20 mil foi aplicada aos depositantes de todas as instituições intervindas e liquidadas após o plano Real (junho/94)". ${ }^{27}$ O FGC nada mais é do que o mecanismo conhecido internacionalmente como seguro de depósito. Ele foi criado na década de 30, nos E.U.A., em meio à dramática crise bancária que se seguiu à recessão. O seguro de depósito tem pelo menos duas importantes funções. A primeira, mais sensível, é garantir aos correntistas de um banco em crise seus recursos nele depositados. A segunda, mais sutil, consiste no efeito psicológico que ameniza a assimetria de informações entre correntistas e instituições financeiras. Em outras palavras, o seguro de depósito corrige uma importante falha do mercado financeiro, aumentando a confiança do público no sistema bancário e diminuindo, portanto os riscos de uma corrida bancária. Nos E.U.A., embora se costume apontar a existência do seguro de depósito e do Federal Deposit Insurance Corporation (FDIC) como um importante fator institucional de prevenção de crises bancárias nos últimos setenta anos o tema é polêmico. ${ }^{28}$

\footnotetext{
${ }^{26}$ Ver o site do Banco Central na Internet, www.bcb.gov.br.

${ }^{27} \mathrm{Id}$.

${ }^{28}$ O sistema, considerado esgotado, foi substancialmente reformado em 1991 (Federal Deposit Insurance Corporation Improvement Act). Para uma avaliação crítica da reforma e de propostas alternativas como a criação de um sistema privado de seguros de depósito, ver George G. Kaufman e Robert E. Litan, (ed.), Assessing bank reform: FDICIA one year later, Washington, D.C.: The Brookings Institution, 1993.
} 
Parte da literatura internacional critica o mecanismo porque ele aumentaria o risco moral: a existência de uma rede de proteção criaria incentivos para os bancos adotarem condutas mais arriscadas, uma vez que, no limite, estariam cobertos pelo seguro de depósito. Não obstante essa crítica, parte dos especialistas ainda entende que a manutenção do seguro de depósito ainda é a melhor solução. De qualquer forma, o fato é que, enquanto nos E.U.A., pratica-se e discute-se a reformulação do FDIC, entre nós a crise bancária encontrou o Brasil despreparado, com uma estrutura de supervisão bancária precária e um arcabouço institucional que não incluía nem procedimentos eficientes de recuperação de bancos "too big to fail" nem o mecanismo de seguro de depósito. Por isso, várias mudanças importantes tiveram que ser efetuadas, o que incluiu a criação urgente de um fundo para garantia de depósitos. Foi o que o CMN fez em agosto de 1995, autorizando a criação do FGC. $^{29}$ Em novembro do mesmo ano, o Conselho aprovou o estatuto e o regulamento do Fundo. ${ }^{30}$ São objetos da garantia os depósitos à vista, depósitos de poupança, depósitos a prazo, letras de câmbio, letras imobiliárias e letras hipotecárias. ${ }^{31}$

Entretanto, o Partido dos Trabalhadores (PT) ajuizou uma ação direta de inconstitucionalidade contra as resoluções do CMN que permitiram a criação do FGC e aprovaram seu estatuto e seu regulamento. ${ }^{32} \mathrm{O}$ PT sustentou que o CMN desrespeitara o art. 192, VI da Constituição e usurpara competência exclusiva do Congresso Nacional, ao regular matéria que somente poderia ser objeto de lei complementar (inconstitucionalidade formal). ${ }^{33}$

Ainda segundo o PT, o Regulamento do FGC, em seu art. $4^{\circ}$, permitia, na hipótese de o patrimônio do FGC ser insuficiente para a cobertura da garantia, que fosse utilizado adiantamento de recursos líquidos da Reserva Monetária, que é formada com o produto da

\footnotetext{
${ }^{29}$ Resolução CMN n ${ }^{\circ}$ 2197, de 31.08.95.

${ }^{30}$ Resolução $\mathrm{CMN} \mathrm{n}^{\circ}$ 2211, de 16.11.95. De acordo com o Estatuto do FGC, não participam do $\mathrm{FGC}$ as cooperativas de crédito e as seções de crédito das cooperativas (anexo I, art. $6^{\circ}$, $\S$ único).

${ }^{31}$ Regulamento (Anexo II), art. $2^{\circ}$. O $\S 1^{\circ}$ do mesmo artigo exclui da garantia os depósitos, empréstimos e quaisquer outros recursos captados ou levantados no exterior, e os créditos de titularidade de pessoas ligadas à instituição (administradores, controladores, sociedades controladas, e coligadas sob controle comum).

${ }^{32}$ ADIn 1.398-0 - DF. Ver LEX-JSTF 218, p.41.

${ }^{33} \mathrm{CF}$, art. 192 (redação da época - bem anterior, portanto, à alteração da Emenda Constitucional 40): "O sistema financeiro nacional, estruturado de forma a promover o desenvolvimento equilibrado do País e a servir aos interesses da coletividade, será regulado em lei complementar, que disporá, inclusive, sobre: [...] VI - a criação de fundo ou seguro, com o objetivo de proteger a economia popular, garantindo créditos, aplicações e depósitos até determinado valor, vedada a participação de recursos da União".
} 
arrecadação do imposto sobre operações financeiras (IOF). Como o IOF é imposto de competência da União, a inconstitucionalidade material do preceito estaria também configurada, uma vez que a Constituição proíbe a participação de recursos da União para esses fins. $^{34}$

Teriam sido violados também os arts. 167 (inc. VIII: vedação da utilização, sem autorização legislativa específica, de recursos dos orçamentos fiscal e da seguridade social para suprir necessidade ou cobrir déficit de empresas, fundações e fundos; e inc. IX: proibição da instituição de fundos de qualquer natureza, sem prévia autorização legislativa) e 37 (legalidade da administração pública).

A outra inconstitucionalidade derivaria do fato de o CMN determinar a extinção do Fundo de Garantia de Depósitos e Letras Imobiliárias (FGDLI) ${ }^{35}$ e da Reserva para a Promoção da Estabilidade da Moeda e do Uso do Cheque (RECHEQUE) ${ }^{36}$, ambos constituídos por recursos públicos, transferindo seu patrimônio para o novo fundo criado, o FGC, que é um fundo privado.

Em seu despacho solicitando informações ao CMN, o Ministro Celso de Mello aceitou o principal argumento da ação:

"[C]om a edição das Resoluções ora impugnadas, parece-me que se degradou para instância juridicamente inadequada o poder de regulação concernente à categoria temática - a criação de fundo ou seguro, com o objetivo de proteger a economia pública e de garantir créditos, aplicações e depósitos até determinado valor - que se acha submetida, em razão de sua própria matéria, ao postulado constitucional da reserva absoluta de lei em sentido formal.

"O Poder Executivo não pode outorgar-se, num inaceitável processo de autoinvestidura, a pretexto de eventual omissão do Congresso Nacional no desempenho

\footnotetext{
${ }^{34}$ Art. 192, VI, cf. nota anterior.

${ }^{35}$ O FGDLI, previsto no art. 17 da Lei 4.380/64, era um fundo de natureza contábil, sem personalidade jurídica, criado para garantir a integridade dos depósitos de poupança e letras imobiliárias, aplicações voltadas para o sistema financeiro da habitação.

${ }^{36}$ O RECHEQUE, criado pela Resolução CMN n ${ }^{\circ} 1.631$, de 24.08.89, fora constituído para patrocinar a divulgação e promoção da defesa da estabilidade da moeda nacional e do uso correto do cheque e para custear despesas com a elaboração e divulgação do Cadastro de Emitentes de Cheques sem Fundos.
} 
de suas funções institucionais, uma prerrogativa jurídica cuja sedes materiae tendo em vista o sistema constitucional de poderes limitados vigente no Brasil - só poderia residir em atos estatais primários editados pelo Poder Legislativo.

$[\ldots]$

"Vê-se, portanto, que o Conselho Monetário Nacional, parecendo olvidar a incontornável necessidade da submissão constitucional do tratamento jurídico de certas matérias ao exclusivo domínio normativo da lei formal, teria concretizado, com o seu comportamento institucional, uma evidente transgressão ao princípio nuclear da separação de poderes" ${ }^{37}$ (grifos meus).

O Ministro Francisco Rezek, relator do processo, seguiu a mesma linha de argumentação, mas, ao votar pela concessão de medida liminar, entendeu que naquele momento o que mais importava era "a possibilidade de utilização de recursos públicos na composição de um fundo privado, criado por resolução para garantir depósitos de clientes de instituições financeiras. Os dinheiros públicos, uma vez gastos, serão de improvável recuperação". ${ }^{38}$ Assim, a medida liminar não abordou a questão da inconstitucionalidade formal, deixando esta para ser resolvida no julgamento definitivo da ação.

Uma vez que o próprio CMN já recuara, revogando, no dia 08.02.96, as suas normas que permitiam o adiantamento de recursos líquidos da Reserva Monetária ${ }^{39}$, o relator entendeu que houve perda parcial do objeto da ação. A medida liminar foi concedida em março de 1996 exclusivamente para suspender a eficácia das normas que permitiam a utilização dos recursos do FGDLI e do RECHEQUE. ${ }^{40}$

Deve-se ressaltar, ainda, um outro aspecto desse caso: o próprio fato de o STF ter considerado a possibilidade de uma resolução do CMN ser objeto de controle de constitucionalidade. Essa posição foi sintetizada pelo Ministro Celso de Mello, em seu despacho de solicitação de informações ao CMN:

${ }^{37}$ LEX-JSTF 218, pp. 54-55.

${ }^{38}$ LEX-JSTF 218, p. 57.

${ }^{39}$ A Resolução CMN no 2249, de 08.02.96, revogou as seguintes normas: Anexo I, art 5 ${ }^{\circ}$, § $2^{\circ}$, III e Anexo II, art. $4^{\circ}$, III da Resolução CMN n ${ }^{\circ} 2211 / 95$.

${ }^{40}$ Resolução CMN 2197/95, art. $5^{\circ}$ e Resolução CMN 2211/95, Anexo II, art. $7^{\circ}$, caput e $\S 1^{\circ}$. 
"Tenho para mim, ao menos para efeito deste juízo de mera delibação - não obstante as referências legislativas constantes do preâmbulo das Resoluções ora impugnadas (o que poderia sugerir fossem ela deliberações de caráter meramente regulamentar, hipótese que não autorizaria o ajuizamento da ação direta) - que os atos em causa, notadamente a Resolução CMN no 2197/95, revestem-se de conteúdo normativo.

"É bastante expressiva, sob tal aspecto, a regra inscrita no art. $6^{\circ}$ da Resolução $n^{\circ}$ 2197/95, no ponto em que dispõe que o mecanismo de proteção a titulares de créditos contra instituições financeiras, de que trata esta Resolução, funcionará enquanto não regulamentado, pelo Congresso Nacional, o art. 192 da Constituição Federal.

"Vê-se, portanto, que o ato em causa foi editado pelo Conselho Monetário Nacional com a evidente finalidade de suprir a exigência constitucional de lei complementar. Na realidade, essa resolução transformou-se em verdadeiro sucedâneo, constitucionalmente não autorizado, da lei complementar exigida pelo art. 192, VI, da Carta Política.

“Tratando-se de deliberação veiculadora de prescrições gerais, abstratas e autônomas, não há como recusar-lhe - ante esse expressivo coeficiente de generalidade abstrata $[\ldots]$ - o caráter de ato normativo, para efeito de instauração da jurisdição constitucional in abstracto do Supremo Tribunal Federal" ${ }^{41}$ (grifos meus).

Não obstante a grande ênfase que os Ministros deram à violação da hierarquia das normas e à separação dos poderes, a medida liminar, como já foi visto, não abordou essa questão. Permaneceram, portanto, tendo eficácia resoluções do CMN que tratam de assuntos de competência exclusiva do Congresso. A esse respeito, vale a pena transcrever o voto do Ministro Marco Aurélio:

"Senhor Presidente, creio que todos nós estamos de acordo quanto à plausibilidade jurídica do pedido, no seu todo. Costumo dizer que as coisas se complicam sempre quando há falha em atividade desenvolvida por determinada instituição. Refiro-me

\footnotetext{
${ }^{41}$ LEX-JSTF 218, pp.52-53.
} 
ao Congresso Nacional no que, passados oito anos, ainda não editou a lei complementar de que cogita o art. 192 da Carta Federal.

$[\ldots]$

"Senhor Presidente, não fosse a repercussão do deferimento de uma liminar em maior extensão, considerados principalmente os pequenos investidores, os pequenos correntistas, não teria a menor dúvida em atuar no campo pedagógico, sinalizando ao autor do ato atacado que ele também deve obediência à Lei Maior, à Constituição Federal. Sensibiliza-me, contudo, o que foi dito relativamente à necessidade de manter-se, com eficácia, parte do diploma atacado visando a proteger justamente esses pequenos investidores. Assim, projeto o exame do vício formal para o julgamento da ação direta de inconstitucionalidade" (grifos meus). ${ }^{42}$

Essa foi a diretriz do julgamento: não obstante o claríssimo vício de inconstitucionalidade formal, o Tribunal, diante da omissão do Legislativo, que ainda não editara a lei complementar que viabilizaria a proteção dos poupadores e investidores garantindo a estabilidade do sistema financeiro -, deveria decidir levando em conta a "repercussão" de uma liminar mais ampla. O exame do vício formal seria portanto "projetado" para o julgamento definitivo da ação, que terminou por não acontecer: em 03/12/2003, mais de sete anos depois, o novo Relator, Min. Nelsom Jobim, decidiu pelo arquivamento do caso, devido à Emenda Constitucional $n^{\circ} 40$, que revogou o inciso VI do art 192, que fundamentava o pedido da ação.

A análise do Caso FGC deixa muito clara uma das estratégias que o STF desenvolveu para lidar com a tensão entre a racionalidade formal do direito e a racionalidade material demandada pelos problemas da regulação da moeda e do crédito no Brasil: “decidir não decidir", ou, mais precisamente, deixar clara a inconstitucionalidade da norma, mas sem declará-la formalmente no julgamento da medida cautelar, adiando o julgamento de mérito até a perda do objeto da ação. Trata-se de uma estratégia informal de decisão que, ao mesmo tempo, (i) reconhece a gravidade da crise econômica - no caso, a crise bancária que se seguiu à implantação do Plano Real; (ii) condena, ao mesmo tempo em que tolera, obiter dictum, a norma formalmente inconstitucional do CMN, por considerá-la de interesse público; e (iii) aposta numa acomodação ou resolução futura do

${ }^{42}$ LEX-JSTF 218, pp. 58-59. 
problema na esfera política ou econômica, fora dos autos. A engenhosidade dessa estratégia consiste numa modalidade informal de self-restraint do Tribunal, que não cria precedentes inaceitáveis para a ordem jurídica: afinal, como justificar, racionalmente, e sendo coerente com a jurisprudência do Tribunal, em nome do interesse público, tamanha inversão da hierarquia das normas, tão explícita afronta ao princípio constitucional da separação dos poderes?

Por outro lado, se optasse pelo rigor de uma racionalidade formal, prolatando uma decisão final de mérito que declarasse a inconstitucionalidade e a conseqüente nulidade das resoluções do CMN que criaram o FGC, o STF extinguiria, no meio de uma crise bancária, um importante instrumento de garantia da estabilidade do sistema financeiro, uma vez que o Congresso ainda levaria um tempo indeterminado para editar a lei complementar do SFN. Ao julgar o pedido de liminar, o Tribunal, portanto, deferiu "o possível”"43, evitando a transferência de verbas públicas para o FGC, mas manteve o Fundo, que tem outras fontes de receita. ${ }^{44}$

No contexto brasileiro, a tensão mais ampla entre racionalidade formal e racionalidade material assume a feição específica de um dilema entre governabilidade substantiva e legitimidade legal-racional. ${ }^{45}$ Nem sempre esse dilema é tematizado de forma tão explícita pelo STF, como ocorreu no caso FGC. Muitas vezes ele é processado pelo Tribunal numa perspectiva formalista, transformado num duelo hermenêutico que oculta o que realmente está em jogo.

\footnotetext{
${ }^{43}$ Voto do Ministro Maurício Corrêa, p.58.

${ }^{44}$ Contribuições das instituiç̧ões associadas, taxas de serviço decorrentes da emissão de cheques sem fundo, dentre outras -- cf. Resolução CMN 2211, Anexo II (Regulamento do FGC), art. $3^{\circ}$.

${ }^{45}$ Ver José Eduardo Faria, Direito e economia na democratização brasileira, São Paulo: Malheiros, 1993, p. 22 (escrevendo sobre o período Collor): "Em suma: como a democratização sem modernização do Estado, sem estabilização econômica e sem mudanças sociais costuma desembocar em ingovernabilidade e como o custo dessa mesma modernização, dessa estabilização e dessas mudanças pode acabar levando à erosão do regime democrático, o desafio [...] se traduz, em termos bastante esquemáticos, pela dificuldade de se saber, na dinâmica política e na especificidade de cada contexto localizado, qual o lado da alternativa que deve ser valorizado quando a complexidade das dificuldades econômicas, num período de transição, atinge níveis explosivos: o lado da acumulação de 'capital democrático' contra as resistências antidemocráticas, que se valem de crises que impedem qualquer cálculo econômico e da incapacidade dos governos para controlá-las com a finalidade de neutralizar e/ou retardar a consolidação da transição; ou o lado da maximização dos instrumentos de política econômica para, mediante a combinação de severas medidas de caráter fiscal e monetário com duras medidas de controle estatal dos preços e salários, reestruturar as contas públicas e disciplinar o sistema produtivo".
} 
Um exemplo disso é dado por um caso muito próximo ao FGC: o Caso Proer. A medida provisória que tratou do Programa ${ }^{46}$ foi atacada por outra ADIn, movida também pelo Partido dos Trabalhadores. ${ }^{47}$ Mais uma vez o art. 192 da Constituição estava no centro do debate. A inicial argumentava que o Proer não poderia ter sido criado por medida provisória, mas somente por lei complementar . No julgamento da medida liminar, o STF, por maioria de votos, entendeu que ${ }^{48}$ (i) o PT equivocara-se, já que o Proer não havia sido criado pela Medida Provisória atacada, mas por uma resolução anterior do $\mathrm{CMN}^{49}$; (ii) o Sistema Financeiro Nacional já se encontrava regulamentado pela Lei 4595/64, recebida pela Constituição de 1988 com o status de lei complementar; (iii) a Lei 4595/64 dava competência ao CMN para criar o Proer; (iv) a Medida Provisória limitou-se a "definir os contornos de programa criado por ato do Conselho Monetário Nacional". ${ }^{50}$

Os raros momentos em que não prevaleceu no julgamento a discussão formalista sobre lei complementar foram dois. Primeiro, o voto do Min. Maurício Corrêa:

\footnotetext{
"Sr. Presidente, essas medidas, na verdade, foram tomadas em face do momento econômico-financeiro por que passa o País. O paradigma foi o fenômeno ocorrido na Venezuela.

"Quando lá estive, na época da quebra do Banco Latino, pude verificar que foi desencadeada uma total desorganização em seu sistema financeiro.

"Apenas citei esse fato para ressaltar a real necessidade da adoção dessas medidas pelo Governo brasileiro"
}

Em seguida, o voto do Min. Marco Aurelio, em sentido contrário:

“[...] Por isso, peço vênia ao nobre Relator para, potencializando, sim, a Carta Política da República, no que representa segurança para toda a sociedade e não uma política governamental momentânea, deferir a liminar pleiteada". ${ }^{52}$

\footnotetext{
${ }^{46}$ Medida Provisória 1.179, de 03/11/1995.

${ }^{47}$ ADIn 1367-9-DF, Rel. Min. Ilmar Galvão, D.J.U. 31/08/2001, Ementário 2041-1, disponível [on-line] in http://www.stf.gov.br.

${ }^{48}$ ADIn 1367-9-DF, voto do Relator, pp. 169-184.

${ }^{49}$ Resolução 2.208, de 06/11/1995.

${ }^{50}$ ADIn 1367-9-DF, voto do Relator, p. 174.

${ }^{51}$ Id., p. 189.

${ }^{52}$ Id., p. 191.
} 
O Caso Proer tem algumas peculiaridades que merecem ser ressaltadas. Em primeiro lugar, embora a norma atacada pela ADIn não fosse uma resolução do CMN, mas uma medida provisória, o argumento para o indeferimento do pedido de medida cautelar foi o reconhecimento pelo Tribunal da competência atribuída pela Lei 4595/64 ao CMN. Em segundo lugar, essa argumentação leva à curiosa conclusão de que uma medida provisória, ato do Presidente da República, estaria fazendo as vezes de um autêntico regulamento de execução da resolução do CMN que criara o Proer, já que, nas palavras do Relator, "em nenhum ponto, pretendeu ela inovar nesse campo [o do sistema financeiro], o que, realmente, lhe seria vedado, assentada que já se acha nesta Corte a impossibilidade de normatização de matéria afeta à lei complementar por meio de medida provisória". ${ }^{53}$ Dito de outro modo: nem o Presidente da República poderia ter inovado a ordem jurídica da forma como o CMN o fez quando criou o Proer. Trata-se, aqui, de um amplo reconhecimento dos poderes normativos do Conselho, que estariam lastreados na Lei 4595/64, recepcionada com status de lei complementar pela nova ordem constitucional.

Ocorreu, porém, que, todas essas questões tematizadas não estabeleceram um precedente: tal qual a ADIn do FGC, a ação que atacava o Proer foi arquivada após mais de sete anos, sem que houvesse uma decisão final de mérito (em 25/02/2003). O arquivamento derivou do fato de o autor da ação, o PT, não ter feito os aditamentos à inicial na medida em que a medida provisória foi sendo reeditada - trata-se de uma exigência do Regimento Interno do STF, confirmada por sua jurisprudência. Em outras palavras, na medida em que o PT perdera o interesse na ação, ela se tornara, na prática, disponível e o Tribunal poderia arquivá-la.

O fato de os Casos FGC e Proer terem sido arquivados evitou que o STF eventualmente formalizasse em decisões finais de mérito uma flagrante incoerência entre dois julgamentos contemporâneos intimamente relacionados entre si, realizados em meio à mesma crise bancária: enquanto no Caso FGC, a resolução do CMN foi duramente criticada por invadir área reservada à lei complementar, caracterizando, segundo o Tribunal, uma clara ofensa ao princípio da separação dos poderes e à hierarquia das normas, no Caso Proer a maioria dos ministros reconheceu tranqüilamente a competência normativa do CMN, afirmando que ela lhe fora atribuída pela Lei 4595/64, que tem

${ }^{53}$ Id., p. 175. 
atualmente status de lei complementar. Essa incoerência não passou despercebida pelo advogado-geral da União, que, na defesa apresentada no Caso FGC, fez referência expressa ao Caso Proer. ${ }^{54}$ Do ponto de vista prático, porém, o resultado dos dois julgamentos foi idêntico: a estratégia informal de self-restraint do STF permitiu que normas importantes para o enfrentamento da crise bancária permanecessem gerando efeitos jurídicos.

Nos casos em que o Tribunal profere uma decisão de mérito, torna-se mais difícil para o STF incorporar ao fundamento da decisão razões consideradas "extra-jurídicas". Como se verá em seguida, isso não impede, todavia, que os debates suscitados pelos Ministros vencidos tematizem de forma veemente o impacto econômico e político da decisão.

A regulação financeira foi objeto de uma das primeiras ações diretas de inconstitucionalidade: A ADIn $n^{\circ} 4,{ }^{55}$ que tornou notória a atuação do STF em matéria de juros. Ela dizia respeito ao art. 192 da Constituição, cujo $\S 3^{\circ}$ estabelecia:

"Parágrafo $3^{\circ}$ As taxas de juros reais, nelas incluídas comissões e quaisquer outras remunerações direta ou indiretamente referidas à concessão de crédito, não poderão ser superiores a doze por cento ao ano; a cobrança acima deste limite será conceituada como crime de usura, punido, em todas as suas modalidades, nos termos que a lei determinar."

A limitação das taxas de juros reais no texto da Constituição de 1988 foi saudada pelos setores progressistas da sociedade brasileira como uma grande conquista da cidadania e do setor produtivo da economia contra o setor financeiro. ${ }^{56}$ A súmula 596 do STF afastara, desde a década de 70, a aplicabilidade da Lei da Usura (Decreto-lei 22.626/33) ao sistema financeiro nacional. A Constituição veio a reintroduzir, portanto, no Brasil, a fixação institucional das taxas de juros.

\footnotetext{
54 Parecer da Advocacia Geral da União, de autoria de Geraldo Magela da Cruz Quintão, in Revista de Direito Bancário e do Mercado de Capitais 1, pp. 152-159 (p. 157).

${ }^{55}$ ADIN 4-DF, D.J.U. 25/06/93, p. 12637. A data do julgamento é 07/03/91.

${ }^{56}$ Ver os trabalhos reunidos em Fernando Gasparian (org.), A luta contra a usura - o limite constitucional dos juros anuais de $12 \%$ está em vigor, São Paulo: Graal, s/d.
} 
Alertado por seus assessores do impacto desestabilizador que a regra provocaria sobre a gestão da moeda e do crédito e sobre a economia como um todo, o Presidente Sarney convocou o Consultor Geral da República, Saulo Ramos, para uma reunião em seu gabinete com autoridades do governo, dentre as quais o Ministro da Fazenda e o presidente do Banco Central. A reunião ocorreu no dia 04 de outubro de 1988, véspera da promulgação da Constituição. Como relatou o próprio Saulo Ramos, em artigo publicado em março de 2003 no jornal Folha de São Paulo, ${ }^{57}$ havia um grande receio de que a entrada em vigor do $\S 3^{\circ}$ do art. 192 “quebrasse" o sistema financeiro:

“A ameaça maior era o par. $3^{\circ}$, que fixava os juros reais em $12 \%$ ao ano, coisa do Fernando Gasparian, que, num momento de padre Vieira e inspirado pelo constituinte Fernando Henrique Cardoso (Comissão de Sistematização, lembramse?), teve a idéia de fixar os juros no texto constitucional, único na história da humanidade e do dinheiro."

Saulo Ramos conta que passou a noite em claro elaborando um parecer que foi publicado no dia seguinte no Diário Oficial da União. Esse parecer, aprovado pelo Presidente da República, adquiriu natureza normativa ${ }^{58}$, passando a vincular a Administração Pública Federal, inclusive o Banco Central. Sustentava a tese de que o parágrafo $3^{\circ}$ do art. 192 - e, portanto, o limite constitucional de $12 \%$ a.a. dos juros reais não era auto-aplicável. Sua eficácia dependeria da edição lei complementar que viesse a regulamentar o sistema financeiro. $\mathrm{O}$ cerne de seu argumento consistiu em alegar a vinculação do $\S 3^{\circ}$ ao caput do art. 192, que prevê a regulamentação do sistema financeiro nacional por lei complementar. Adicionou a isso a necessidade de legislação infraconstitucional que definisse "juros reais", inclusive para que houvesse a adequada caracterização do crime de usura ao qual a Constituição se refere.

No dia 06 de outubro, o BCB editou a Circular 1365, que, em nome da "segurança jurídica", tinha o objetivo de "esclarecer", respaldada no Parecer, que "enquanto não for editada a Lei Complementar reguladora do Sistema Financeiro Nacional, prevista no artigo 192 da Constituição da República Federativa do Brasil, as operações ativas, passivas e

${ }^{57}$ Folha de São Paulo, 26.03.2003, p. A-3. Todos os trechos citados de Saulo Ramos são extraídos do mesmo artigo.

${ }^{58}$ É o que determinava o Decreto $92.889 / 86$, arts. $22, \S 2^{\circ}$, e 23. 
acessórias das instituições financeiras e demais entidades sujeitas à autorização de funcionamento e fiscalização por parte do Banco Central do Brasil permanecerão sujeitas ao regime das Leis n.s 4.595, de 31.12.64, 4.728, de 14.07.65, 6.385, de 07.12.76 e demais disposições legais e regulamentares vigentes aplicáveis ao Sistema Financeiro Nacional” (grifei).

Houve forte reação da sociedade civil e dos formadores de opinião. Continuemos com o relato de Saulo Ramos:

\footnotetext{
"A imprensa atirou de todos os lados. Confundiu tudo e baralhou mais o debate. Diante de palavras como anatocismo, aumentaram as vendas de dicionários. Mas um aspecto curioso da discussão sobre o entrar ou não em vigor deu-se na semana seguinte, num restaurante de Brasília, onde fui almoçar e encontrei o então senador Fernando Henrique Cardoso. Ele me questionou:

“"Você pensa que vai impedir a vigência da Constituição com um simples parecer jurídico?'

“'Penso.'

"E o Supremo Tribunal pensou a mesma coisa."
}

De fato, a questão foi levada ao STF por meio da ADIn n ${ }^{\circ}$ 4. A ação teve como autor o Partido Democrático Trabalhista (PDT), que pediu a declaração de inconstitucionalidade do Parecer da Consultoria Geral da República ${ }^{59}$. Do ponto de vista processual, o que tecnicamente viabilizou o controle de constitucionalidade do parecer foi a sua natureza normativa, adquirida, como já explicado, com a sua aprovação pelo Presidente da República.

Na petição inicial, assinada por Paulo da Matta Machado, advogado do PDT, a argumentação de caráter essencialmente formal do Parecer foi exaustiva e brilhantemente desmontada. Com respaldo na hermenêutica constitucional clássica (Cooley, Ruy Barbosa), a tese da inicial demonstrava (i) que a relação entre o caput do art. 192 e seus parágrafos era de coordenação - e não de subordinação -, o que implicava a autoaplicabilidade do $\S 3^{\circ}$; (ii) que toda norma de proibição é auto-aplicável; (iii) que a história do processo legislativo constituinte confirmava que o plenário da Assembléia estava

\footnotetext{
${ }^{59} \mathrm{SR} \mathrm{n}^{\circ} 70$, de 06/10/1988.
} 
consciente de votar uma norma que teria aplicação imediata - a vontade do constituinte era demonstrada por uma declaração do seu relator, Bernardo Cabral, que constava dos anais da Constituinte. A tese do PDT foi defendida por vários constitucionalistas, como José Afonso da Silva:

"Pronunciamo-nos, pela imprensa, a favor de sua aplicabilidade imediata, porque se trata de uma norma autônoma, não subordinada à lei prevista no caput do artigo. Todo parágrafo, quando tecnicamente bem situado (e este não está, porque contém autonomia de artigo), liga-se ao conteúdo do artigo, mas tem autonomia normativa. Veja-se, por exemplo, o $\S 1^{\circ}$ do mesmo art. 192. Ele disciplina assunto que consta dos incisos I e II do artigo, mas suas determinações, por si, são autônomas, pois uma vez outorgada qualquer autorização, imediatamente ela fica sujeita às limitações impostas no citado parágrafo.

"Se o texto em causa fosse um inciso do artigo, embora com normatividade formal autônoma, ficaria na dependência do que viesse a estabelecer a lei complementar. Mas, tendo sido organizado num parágrafo com normatividade autônoma, sem referir-se a qualquer previsão legal ulterior, detém eficácia plena e aplicabilidade imediata. O dispositivo, aliás, tem autonomia de artigo, mas a preocupação, muitas e muitas vezes revelada ao longo da elaboração constitucional, no sentido de que a Carta Magna de 1988 não aparecesse com demasiado número de artigos, levou a Relatoria do texto a reduzir artigos a parágrafos e uns e outros, não raro, a incisos. Isso, no caso em exame, não prejudica a eficácia do texto."60

Além da argumentação técnico-jurídica de caráter formal, o PDT argumentou que no Estado Social e Democrático de Direito, é tarefa das normas constitucionais de intervenção no domínio econômico controlar "as autonomias privadas egoísticas e deletérias ao bem comum”. À Constituição, portanto, deveria se aplicar uma interpretação teleológica, que visasse ao "progresso coletivo da sociedade e do País". O encerramento da inicial dá-se com o apelo para que o STF respeitasse a decisão política do constituinte, e se posicionasse contra a "usura".

${ }^{60}$ Cf. José Afonso da Silva, Curso de Direito Constitucional Positivo, 14. ed, São Paulo: Malheiros, p. 758. 
Foi assim que a discussão sobre o poder de regular os juros na nova ordem constitucional transformou-se, ao mesmo tempo, num debate jurídico formal sobre aplicabilidade das normas constitucionais e numa luta política - levada ao Tribunal - do bem contra o mal.

O STF abraçou, por apertada maioria de votos $(6 \times 4)$, a tese do Consultor Geral da República. Embora a decisão final tenha sido lavrada em termos lógico-formais, é equivocada a visão de que o Tribunal tenha se limitado a discutir a relação entre os parágrafos e o caput de um artigo. Em meio a um grande debate sobre métodos de interpretação constitucional, os Ministros desenvolveram argumentos que claramente fugiam aos limites estreitos de uma interpretação voltada para a topografia das normas. ${ }^{61}$

Uma das passagens mais fortes da decisão é o trecho final do voto do Min. Carlos Velloso, que se declarou favorável à aplicabilidade imediata do limite dos juros. Após ressaltar a "importância do método sociológico ou do elemento político-social na interpretação", 62 o Min. Velloso afirmou:

\begin{abstract}
"Nós sabemos, Senhor Presidente, que as taxas de juros que estão sendo praticadas, hoje, no Brasil, são taxas que nenhum empresário é capaz de suportar. Nós sabemos que o fenômeno que se denomina, pitorescamente, de 'ciranda financeira', é que é a tônica, hoje, do mercado financeiro, engordando os lucros dos que emprestam dinheiro e empobrecendo a força do trabalho e do capital produtivo.
\end{abstract}

"Tudo isso eu devo considerar e considero, Senhor Presidente, quando sou chamado, como juiz da Corte Constitucional, a dizer o que é a Constituição."63 (grifos meus).

\footnotetext{
${ }^{61} \mathrm{O}$ caso impressiona pela quantidade de pareceres de importantes juristas que foram juntados aos autos. Em seu voto, o Relator Min. Sydney Sanches declarou expressamente que acolhia a fundamentação dos pareceres de Hely Lopes Meirelles, Caio Tácito, José Frederico Marques, Manoel Gonçalves Ferreira Filho, Celso Bastos, Ives Gandra da Silva Martins, José Alfredo de Oliveira Baracho, Rosah Russomano, Cid Heráclito de Queiroz, Arnoldo Wald e Geraldo Vidigal - todos eles contrários à auto-aplicabilidade do $\S 3^{\circ}$ (p. 805). Dentre as vozes dissonantes na doutrina, destacaram-se José Afonso da Silva e Eros Roberto Grau. 62 p. 820.

63 Id. ib.
} 
Em contraposição, o Min. Célio Borja manifestou-se de forma taxativa contra a possibilidade de o STF levar em conta "considerações que não sejam estritamente jurídicas". ${ }^{64}$ Para ele, que votou contrariamente à auto-aplicabilidade do $\S 3^{\circ}$, o impacto econômico da decisão do Tribunal - a definição das taxas de juros reais - não pode ser apreciada pelo Judiciário, pois é matéria da alçada “dos poderes políticos da Nação, não dos juízes, dos magistrados". ${ }^{65}$

Essa tensão entre racionalidade formal e racionalidade material foi radicalizada, nesse caso, pelo memorando do Banco Central que apontava os efeitos catastróficos da fixação institucional da taxa de juros, tais como: (i) desintermediação financeira, (ii) desestímulo à poupança financeira, especialmente as aplicações de longo prazo, (iii) fuga de capitais das aplicações financeiras para operações especulativas, (iv) dificuldades na condução da política monetária pelo Banco Central, (v) aumento do risco de hiperinflação, (vi) incompatibilidade com o sistema de taxas flutuantes do mercado financeiro internacional, (vii) endurecimento da política fiscal, devido à dificuldade de financiamento interno e externo, (viii) exclusão do Brasil do mercado de crédito internacional, (ix) possibilidade de fuga de capital para o exterior. ${ }^{66}$ Em sua argumentação, o BCB tentou demonstrar, primeiro, a incongruência entre um regime constitucional que tabelava os juros e o mercado financeiro internacional, e, em segundo lugar, o enorme constrangimento que a regra constitucional criaria para a gestão governamental das políticas fiscal, monetária e creditícia. O tabelamento dos juros implicaria a execução de uma política monetária passiva, o que condenaria o governo a ter que optar entre duas estratégias extremas de política econômica: ou o ajuste fiscal ortodoxo ou a expansão monetária hiperinflacionária. ${ }^{67}$

Percebe-se, assim, como considerações não “estritamente jurídicas” poderiam ser utilizadas para defender posições contrárias: (i) por um lado, o combate à usura, a defesa "da força do trabalho e do capital produtivo", como argumento favorável à autoaplicabilidade do art. 192, § $3^{\circ}$; (ii) por outro, a desestruturação do sistema econômico como condenação do limite constitucional dos juros. Não foi isso, porém, que ocorreu.

\footnotetext{
${ }^{64}$ p. 848 .

${ }^{65}$ p. 846.

${ }_{66}^{66}$ pp. 759-760.

${ }^{67}$ p. 763.
} 
Enquanto os ministros favoráveis ${ }^{68}$ ao tabelamento dos juros registraram sua crítica à usura - com exceção do Min. Néri da Silveira -, o formalismo prevaleceu entre aqueles que se posicionaram contrariamente à aplicabilidade imediata do $\S 3^{\circ} .^{69} \mathrm{O}$ formalismo foi dominante, portanto, na própria decisão do Tribunal, com a vitória da fundamentação do voto do Relator, que pode ser resumida nos seguintes pontos: (i) a subordinação do parágrafo ao caput, do que deriva a não auto-aplicabilidade daquele primeiro; (ii) a necessidade de lei que definisse "juros reais".

Para quem não leu a íntegra dos votos, o resultado final do julgamento, consubstanciado na ementa da decisão, parece algo distante do real dilema envolvido no caso: interpretar ou não a Constituição de modo a retirar da autoridade monetária sua competência para fixar as taxas de juros de acordo com a conjuntura, ou seja, permitir ou não que o espírito anti-usura consagrado no texto constitucional restabelecesse a fixação institucional dos juros abolida pela súmula 596 do STF. Embora esse dilema tenha sido encoberto pela argumentação formalista prevalecente no julgamento - e portanto na ementa - da ADIn 4, eles estiveram presentes - e muito presentes - durante a longa sessão em que o Tribunal deliberou.

Assim como nos casos FGC e Proer, o dilema entre governabilidade substantiva e legitimidade legal-racional também está presente nesse julgamento do STF. Fazer cumprir a norma constitucional causaria enorme embaraço para as políticas econômica e monetária do Executivo, uma vez que o nível da taxa de juros é variável macroeconômica cuja livre manipulação pelo Governo e pelas autoridades monetárias é fundamental para a gestão da política econômica. Em outras palavras, o texto constitucional restabeleceu a ideologia anti-usura do Decreto 22.626, inaplicável num contexto econômico internacional de taxas flutuantes.

A análise detalhada do caso permite verificar que a argumentação da petição inicial do PDT, respaldada pela doutrina clássica (Cooley/Ruy Barbosa), é irrebatível, e que a tese desenvolvida no Parecer do Consultor Geral, abraçada pela maioria do STF e pelos vários pareceres de prestigiosos juristas, exaustivamente transcritos no voto do Relator, não

\footnotetext{
${ }^{68}$ Votaram pela procedência da ADIn os Ministros Marco Aurélio, Carlos Velloso, Paulo Brossard e Néri da Silveira.

${ }^{69}$ Ministros Celso de Mello, Célio Borja, Octavio Gallotti, Aldir Passarinho e Moreira Alves.
} 
convence. Não se trata, aqui, de adentrar uma disputa doutrinária, opinando sobre a melhor interpretação das normas constitucionais. O que se afirma é que a tese contrária à aplicabilidade imediata do limite dos juros era claramente "forçada", e visava a legitimar enquanto fundamentação racional-formal - uma decisão de conseqüências mais profundas sobre o poder de regular os juros, decisão essa que levava em conta as conseqüências econômicas e políticas do julgamento da ADIn.

O STF adotou neste caso uma postura que se tem repetido em outros hard cases. Quando resolve abandonar uma hermenêutica mais convencional, tendo em vista as conseqüências de suas decisões, não o faz explicitamente. Ou adia o julgamento do mérito até a mudança da conjuntura, ou desenvolve uma argumentação ad hoc. A primeira atitude foi adotada nos casos FGC e Proer. A última, no julgamento da ADIn 4. Em todos os casos, o STF decidiu de maneira tal que conseguiu repassar para a esfera política o ônus de uma decisão definitiva: (i) no caso $\mathrm{FGC}$, o julgamento do mérito da ação seria provavelmente adiado até que o Congresso editasse lei regulamentadora do art. 192 da Constituição e decidisse, então, manter ou não o seguro de depósito criado pelo CMN enquanto isso não ocorresse, a resolução do CMN que criou o FGC continuaria, portanto, fazendo as vezes de lei complementar, ou seja, o CMN teria efetivamente legislado ${ }^{70}$; (ii) no caso da limitação dos juros reais, o Congresso é que teria que decidir, quando da elaboração daquela mesma lei do sistema financeiro nacional, se insistiria na promessa original (da Assembléia Constituinte) do tabelamento dos juros, ocasião em que o próprio Congresso - e não o STF - tomaria a decisão política (no sentido de policy) de tabelar os juros; (iii) no caso Proer, a medida provisória que "detalhava" a resolução do CMN que criara o programa poderia ser rejeitada pelo Congresso Nacional em alguma de suas reedições, o que nunca ocorreu. Como o próprio partido de oposição perdera o interesse na sua contestação, já que não mais aditara a inicial, a ação foi arquivada.

Ambas as atitudes - adiar julgamentos de mérito de hard cases ou julgar o mérito mediante a construção de argumentos jurídicos ad hoc que ocultam uma racionalidade material com vistas às conseqüências econômicas e políticas das próprias decisões demonstram o desafio que a dinâmica política da jovem democracia brasileira tem

\footnotetext{
${ }^{70}$ Essa função legislativa não poderia nem ser delegada ao Presidente da República - segundo o $\S 1^{\circ}$ do art. 68 da Constituição, as matérias reservadas à lei complementar não podem ser objeto dessa delegação.
} 
apresentado ao STF: será possível reconstruir a interpretação constitucional de modo a incorporar aquilo que o Ministro Célio Borja denominou de considerações não “estritamente jurídicas"? Da forma como os casos analisados foram tratados, os reais dilemas neles envolvidos foram obscurecidos por um falso dilema entre duas posições jurídicas igualmente formais.

Assim, o STF resiste em processar e incorporar formalmente ao que a maioria de seus ministros entende ser uma racionalidade propriamente jurídica os imperativos da governabilidade, a noção de interesse público, as variáveis macroeconômicas, em suma, os elementos tidos como extrajurídicos, materiais, morais, econômicos, políticos. Ao fazer isso, porém, o Tribunal não elimina esses elementos, antes os preserva, ocultos, de tal modo que eles deixam de ser facilmente reconhecíveis e criticáveis pela comunidade jurídica, pelas organizações da sociedade civil organizada, pelos cidadãos em geral.

Essa característica da argumentação do STF, que confere uma falsa aparência de "pureza" do direito a decisões que definem - ainda que provisoriamente - policies, é ainda mais relevante na medida em que se constata que essas decisões confirmam ou realocam recursos de poder, ou seja, mantêm ou transformam a distribuição de competências normativas entre os diversos agentes políticos. ${ }^{71}$ Assumindo que ter competência normativa significa poder inovar a ordem jurídica - o que não é diferente de produzir lei em sentido material -, as decisões do STF que definem as chamadas regras secundárias em termos hartianos - redefinem, a todo momento, a configuração institucional da separação dos poderes brasileira. Isso inclui, obviamente, redefinir a extensão dos poderes normativos da burocracia reguladora do mercado financeiro.

Nos casos estudados, portanto, por trás das disputas dogmáticas, paira a desafiadora racionalidade da burocracia econômica, que, em nome do interesse público, tende a submeter o princípio democrático, a separação dos poderes e a hierarquia das normas aos imperativos da estabilidade sistêmica.

\footnotetext{
${ }^{71}$ O termo “agente político", aqui, não está empregado no sentido técnico-jurídico.
} 
3. O poder normativo da burocracia: reconhecimento sem controle

Embora os casos estudados até aqui tenham provocado efeitos práticos favoráveis ao poder normativo do $\mathrm{CMN}$ e do $\mathrm{BCB}$, eles não explicitaram a que título tais poderes são exercidos: se ele é decorrente de uma ampliação do poder regulamentar ou de delegação legislativa. O que se verá a seguir é como o STF abordou essa questão em alguns casos que são extremamente importantes, mas aos quais não se tem prestado a devida atenção no debate jurídico no Brasil.

O tema da delegação legislativa foi discutido pelo STF no importante caso que tratou da contribuição para o Instituto do Açúcar e do Álcool (IAA). Embora julgando em novembro de 1996 o Caso Usina Caeté, o Tribunal adotou, como norma de regência a Constituição de $1969 .^{72}$ Esta última definia como "independentes e harmônicos"os poderes Legislativo, Executivo e Judiciário, vedando expressamente "a qualquer dos Poderes delegar atribuições", admitindo apenas as exceções que ela própria previa. ${ }^{73}$ Estabelecia ao mesmo tempo um arranjo institucional em que o Presidente da República exercia função legislativa mediante decreto-lei. Como o Tribunal reconhecia o decreto-lei como tendo o mesmo status da lei em sentido formal, a delegação de certas atribuições do Presidente para uma autarquia ou para um Ministro de Estado era discutida pelo STF como problema de delegação legislativa.

As conclusões a respeito desse caso devem portanto se restringir ao período constitucional referido, como ressaltaram diversos ministros em seus votos. Apesar disso, o que esta breve análise pode demonstrar é que há entendimentos que podem sobreviver à mudança constitucional, uma vez que não dizem respeito ao princípio da legalidade estrita no campo tributário, que impediria, atualmente, a criação de contribuição pelo Executivo.

A contribuição discutida no caso foi criada por um decreto-lei em fevereiro de 1967, com o objetivo de financiar a intervenção da União no setor de açúcar e álcool. O decreto-lei, que estipulava valores nominais para as contribuições, conferia ao IAA a

${ }^{72}$ STF, Recurso Extraordinário (RE) 178.144-1/AL (Caso Usina Caeté S/A, 1996, disponível em http://www.stf.gov.br, com a paginação original dos autos). O Tribunal refere-se quase sempre à "Emenda Constitucional 1/69" ou à "Constituição de 67", e não à "Constituição de 69".

${ }^{73} \mathrm{CF} 69$, art. $6^{\circ}$. 
competência de corrigir proporcionalmente esses valores, de acordo com a conjuntura. ${ }^{74}$ Doze anos depois, um outro decreto-lei determinou que caberia ao CMN reajustar o valor das contribuições. ${ }^{75}$ Em 1982, um terceiro decreto-lei criou um adicional às contribuições, atribuindo mais uma vez ao CMN a competência para estabelecer os percentuais. ${ }^{76}$

Ao julgar um recurso extraordinário interposto pela Usina Caeté S/A, o Tribunal entendeu que a delegação via decreto-lei da atribuição de fixar alíquotas ao CMN não era inconstitucional, pois vinha acompanhada de limites $-20 \%$ dos preços oficiais do açúcar e do álcool - e de condições - haver uma proposta do Ministro da Indústria e do Comércio previstos nos decretos-leis. Segundo o relator, Ministro Marco Aurélio, “[p]elo decreto-lei, deu-se uma verdadeira carta branca, ao Conselho Monetário, para atuar". ${ }^{77}$ A competência para fixar as alíquotas era do Poder Executivo, que é unipessoal - o Presidente da República. Este não poderia, ainda de acordo com o relator, delegar a competência para uma autarquia. Entretanto, prevaleceu o entendimento de que a Constituição de 69 permitia ao Presidente delegar as atribuições que lhe eram privativas. ${ }^{78}$

\footnotetext{
${ }^{74}$ Decreto-lei 308, de 28 de fevereiro de 1967, art. 3: "Para custeio da intervenção da União, através do Instituto do Açúcar e do Álcool, na economia canavieira nacional, ficam criadas, na forma prevista no art. 157, § $9^{\circ}$, da Constituição Federal de 25 de janeiro de 1967, as seguintes contribuições: I - de até NCr\$ 1,57 por saco de açúcar de 60 quilos destinados ao consumo interno do País; II - de até NCr\$ 0,01 por litro de álcool de qualquer tipo e graduação destinado ao consumo interno, excluído o álcool anidro para mistura carburante. $\S 1^{\circ}$. As contribuições a que se refere este artigo serão proporcionalmente corrigidas pela Comissão Executiva do Instituto do Açúcar e do Álcool em função da variação dos preços do açúcar e do álcool, fixados para o mercado nacional."

${ }^{75}$ Decreto-lei 1.712/79, art. $3^{\circ}$ : "Mediante proposta do Ministério da Indústria e do Comércio, o Conselho Monetário Nacional poderá reajustar o valor das contribuições de que trata este Decreto-lei, observado o limite máximo de $20 \%$ dos preços oficiais do açúcar e do álcool."

${ }^{76}$ Decreto-lei 1952/82, art. $1^{\circ}, \S 2^{\circ}$ : "Mediante proposta do Ministro da Indústria e do Comércio, o Conselho Monetário Nacional estabelecerá os percentuais do adicional ora instituído, considerando os tipos de açúcar e de álcool ou a sua destinação final”.

${ }^{77}$ Caso Usina Caeté S/A, p. 319.

${ }^{78}$ Id., voto do Min. Maurício Correa (relator para o acórdão), pp. 310-11 (interpretando o parágrafo único e o inciso V do art. 81 da Constituição de 69). Os debates da sessão deixam isso ainda mais claro: "Min. Marco Aurélio (Relator): 'Ministro, quando na Constituição há referência a Poder Executivo, cuida-se de órgão unipessoal, o Presidente da República.’ Min. Carlos Velloso: ‘Aí é que está Ministro Marco Aurélio, ela não se refere ao Presidente da República. A Constituição, em diversos passos, refere-se a Presidente da República, mas não neste caso. Por mais de uma vez discutimos essa questão no antigo Tribunal Federal de Recursos, entendendo que quando a Constituição fala em Poder Executivo, não está estabelecendo que seria o Presidente da República, mas o órgão técnico indicado para essa atividade. E veja V. Exa. que o Conselho Monetário Nacional tinha atribuições amplíssimas. Não fala em Presidente da República, fala em Poder Executivo, quer dizer, órgãos do Poder Executivo poderiam fazer a alteração. O decreto-lei estabeleceu o teto que seria, então, 20\%; o piso, é claro, se não estabelecido, é zero. Penso que não há inconstitucionalidade no caso." (Id., p. 324).
} 
A relevância do caso poderia ser sintetizada, portanto, em dois itens: (i) sob a égide da Constituição de 69, o STF aceitou que a atribuição de fixar alíquotas fosse assumida pelo CMN como uma forma de delegação de atribuição que se entendia de caráter legislativo, qual seja, a fixação de alíquotas de uma contribuição (e de seu adicional), espécie do gênero tributário; (ii) "Poder Executivo" não queria dizer somente "Presidente da República", o que implicava que o Presidente poderia delegar suas atribuições a uma autarquia.

Esse caso fornece alguns elementos para a configuração do que seria a doutrina da vedação da delegação legislativa da Constituição de 69. O debate envolvendo o "créditoprêmio" pode ajudar a detalhar aquela doutrina. Em dezembro de 1979, um decreto-lei ${ }^{79}$ autorizou o Ministro da Fazenda a aumentar ou reduzir, de forma temporária ou definitiva, ou mesmo extinguir os incentivos fiscais concedidos por um outro decreto-lei, de março de $1969^{80}$. O Ministro exerceu essa competência mediante portaria ${ }^{81}$. Julgando o caso, o STF decidiu por apertada maioria ${ }^{82}$ que a delegação era inconstitucional. ${ }^{83} \mathrm{O}$ relator, Min. Carlos Velloso, ${ }^{84}$ lembrou em seu voto que havia tratado da mesma questão - o mesmo decreto-lei -- no antigo Tribunal Federal de Recursos, ${ }^{85}$ e reiterou seu entendimento também vitorioso no TFR -- de que o Presidente não pode delegar competência para editar um ato normativo primário, que inova a ordem jurídica - poder de extinguir um incentivo fiscal concedido por um decreto-lei -- a um Ministro de Estado, devido à vedação constitucional da delegação de atribuições: "Não pode o Presidente da República, ao editar decreto-lei, delegar a uma autoridade administrativa o descumprimento de um ato

\footnotetext{
${ }^{79}$ Decreto-lei 1.724, de 07/12/1979, art. 1 ${ }^{\text {o: }}$ "O Ministro de Estado da Fazenda fica autorizado a aumentar ou reduzir, temporária ou definitivamente, ou extinguir os estímulos fiscais de que tratam os artigos $1^{\circ}$ e $5^{\circ}$ do Decreto-Lei no 491, de 5 de março de 1969".

${ }^{80}$ Decreto-lei 491/69.

${ }^{81}$ Portaria 960/79 do Ministro da Fazenda.

${ }^{82}$ Favoráveis à delegação: Ministros Nelson Jobim, Maurício Correa, Ilmar Galvão e Octavio Gallotti. Contrários a ela: Ministros Carlos Velloso, Marco Aurélio, Sepúlveda Pertence, Sydney Sanches, Néri da Silveira e Moreira Alves.

${ }^{83}$ RE 186.623-3 RS, 26/11/2001, publicado no D.J. 12/04/2002, ementário 2064-4 (Caso Crédito-Prêmio). A paginação aqui usada é a original, a partir da versão obtida no website do STF. Essa decisão passou a ser o "leading case" sobre a matéria, como demonstram o seguintes casos: RE 180.828-4 RS (14/03/2002), RE 186.359-5 RS (14/03/2002), RE 213.677/RS (01/10/2002), RE 175.371/RS (08/10/2002), RE 183.057 (14/11/2002), RE 186.353 (14/11/2002), RE 196.394 (14/11/2002) e RE 268.553 AgR-ED/RJ (19/08/2003).

${ }^{84} \mathrm{RE}$ 186.623-3 RS, voto do Min. Carlos Velloso, pp. 706-13.

${ }^{85}$ Argüição de inconstitucionalidade na AC 109.896-DF, Rel. Min. Pádua Ribeiro, 27/08/1987.
} 
normativo primário, na linguagem de Kelsen, vale dizer, de um ato normativo que inova a ordem jurídica" ${ }^{86}$

O interessante debate que também surgiu nessa decisão foi sobre a natureza do benefício extinto pela portaria do Ministro da Fazenda. Segundo o entendimento vitorioso do relator, tratava-se de isenção tributária, sujeita ao princípio da legalidade e à principiologia do direito tributário como um todo. A posição derrotada sustentava que o incentivo era um crédito-prêmio, ou seja, um "incentivo destinado ao incremento das exportações e, conseqüentemente, a uma função econômica, conjuntural". ${ }^{87}$ A contraposição entre a posição formalista e aquela que via o incentivo fiscal como créditoprêmio - um instrumento foi assim resumida pelo Min. Sepúlveda Pertence: “Sr. Presidente, independentemente dos resultados extra-jurídicos com que acena o eminente Ministro Nelson Jobim, fico, com todas as vênias, no campo dos princípios." 88

A posição do antigo TFR em relação ao crédito-prêmio foi portanto mantida pelo STF quatorze anos depois, quando este último voltou a interpretar a Constituição de 69, após a revogação desta, para tratar do mesmo assunto. Para um observador externo à comunidade jurídica, o problema da delegação legislativa interna ao Executivo parece um formalismo inócuo. Afinal de contas, se o Presidente Figueiredo delegara ao Ministro da Fazenda competências de caráter legislativo típicas de decreto-lei para intervir na política de exportações, manipulando ou mesmo extinguindo incentivos fiscais, qual seria o problema? Sob o presidencialismo, especialmente no período autoritário, o mínimo que se espera é que um ministro de Estado seja fiel às políticas do chefe de governo. Se isso não ocorre, o ministro pode ser demitido ad nutum. Assim, se é o próprio Presidente quem “legisla"ou se quem o faz é seu Ministro, por delegação, tudo se resumiria ao estilo de gestão do Presidente.

As coisas, porém, não são tão simples quanto parecem. Em primeiro lugar, porque, quando se fala em delegação legislativa interna ao Executivo, outros órgãos que não os Ministros não podem ser esquecidos, como no caso da Usina Caeté. A delegação

\footnotetext{
${ }^{86}$ Trecho do voto do Min. Velloso na AC 109.896-DF (TFR), transcrito no RE 186.626-3 RS, p. 710.

${ }^{87}$ Voto do Min. Ilmar Galvão no RE 186.626-3 (p. 727), que também participou do julgamento do AC 109.896 quando integrante do TFR.

${ }^{88}$ RE 186.626-3, p. 734.
} 
legislativa para setores da burocracia estatal tem efeitos distintos da delegação feita para o primeiro escalão, principalmente se a diretoria da autarquia tem mandato - ou seja, se a autarquia tem autonomia decisória garantida em lei. Embora essa não tenha sido à época do Caso Usina Caeté nem ainda seja atualmente a situação dos reguladores do mercado financeiro - com exceção da CVM --, a autonomia pode vir a ser amplamente criada numa eventual mudança do modelo regulatório brasileiro para esse setor.

Em segundo lugar, a construção pelo STF de uma doutrina sobre a delegação legislativa interna ao Executivo é importante pela simples razão de que a jurisprudência do Tribunal tem que ser levada a sério tanto pelo operador do direito quanto pelo observador cuja única preocupação é compreender as tranformações dos cânones do direito público e do papel das instituições e da cultura jurídica. A construção dessa doutrina pelo STF é elemento importante da montagem da doutrina mais ampla da separação dos poderes. Com a mudança da Constituição, os casos Usina Caeté e Crédito-prêmio, "pendências" do regime autoritário, são referências a serem observadas para se compreender melhor a interpretação que o STF tem dado à nova separação dos poderes do Brasil redemocratizado, especificamente no que se refere ao tema da delegação legislativa, mediante a regra de transição do art. 25 do ADCT.

Em seu voto no Caso do Crédito-Prêmio, o Min. Moreira Alves, reconhecido pelo seu rigor no trato da dogmática jurídica, foi muito claro: o decreto-lei que autorizou o Ministro da Fazenda a extinguir incentivos fiscais, independentemente da posição sobre a natureza jurídica do crédito-prêmio, suscita um problema constitucional de "delegação de competência legislativa": 89

"Com efeito, ainda quando se entenda que, na vigência da Emenda Constitucional $\mathrm{n}^{\mathrm{o}} 1 / 69$, se admitia, como no direito constitucional norte-americano, a delegação legislativa a autoridades administrativas quando essa outorga fosse limitada por padrão ou padrões determinados na Lei, o certo é que, no caso, a delegação feita pelo Decreto-Lei $n^{\circ}$ 1724/79 - e se trata de delegação legislativa, porquanto a edição de Decreto-Lei se situa na competência do Presidente da República, no exercício de função legislativa, e, no que diz respeito à extinção do

${ }^{89}$ Id., p. $738-9$. 
incentivo em causa, implica ela cessação de eficácia do próprio Decreto-Lei delegante - é incondicionada à observância de qualquer padrão determinado por esse diploma com força de lei, o que acarreta a inconstitucionalidade dessa delegação. “90

Esse entendimento sobre o que está em jogo - a construção de uma doutrina da delegação legislativa vis-à-vis a vedação constitucional da delegação de atribuições - não destoa dos votos dos demais Ministros.

Entretanto, o que não fica claro a partir da comparação dos casos Usina Caeté e Crédito-Prêmio é que tipo de doutrina o STF busca construir. Os casos são contraditórios e dificultam o processo de consolidação de uma doutrina da separação dos poderes pelo Tribunal - no que se refere à Constituição de 69, deve-se sempre lembrar. Reforça essa análise trecho do voto do Min. Maurício Corrêa que, ao julgar um outro recurso que tratou do crédito-prêmio, ${ }^{91}$ defendeu a constitucionalidade da delegação fazendo uma referência expressa ao caso Usina Caeté. Em ambos os casos, (i) está presente o elemento extrafiscalidade , (ii) a Constituição autorizava a alteração de alíquotas e base de cálculo pelo Executivo, ${ }^{92}$ e (iii) competências tributárias de caráter legislativo foram delegadas pelo Presidente da República mediante decreto-lei. Diante de situações tão semelhantes, fica difícil entender por que o STF produziu decisões diametralmente opostas. Do imbróglio jurisprudencial, o CMN saiu fortalecido.

Boa parte dos debates jurídicos relativos ao poder normativo do CMN e do Bacen pode ser melhor compreendida com uma breve digressão sobre a questão do limite das taxas de juros. Um bom ponto de partida para tratar desse assunto é a Súmula 596 do STF:

Súmula 596: As disposições do Decreto 22.626 de 1933 não se aplicam às taxas de juros e aos outros encargos cobrados nas operações realizadas por instituições públicas ou privadas que integram o sistema financeiro nacional. ${ }^{93}$

\footnotetext{
${ }^{90}$ Id. p. 739.

${ }^{91}$ RE 186.359-5 RS, p. 212 (paginação original, versão disponível no website do STF).

92 Contribuições de intervenção na ordem econômica: CF 69, art. 21, §2º, I, c/c 21, I; IPI: CF 69, art. 21, V, c/c 21, I.

${ }^{93}$ Publicada no DJ de 03/01/77, p. 7.
} 
Em seus comentários a uma decisão do STF do ano de $1971^{94}$, Fábio Konder Comparato $^{95}$ antecipou o que cinco anos mais tarde seria o conteúdo dessa súmula. $\mathrm{O}$ acórdão analisado deveria cuidar da seguinte questão: no Estado da Guanabara, o cliente de um banco pedia em juízo a anulação da cláusula contratual que estipulava o pagamento de uma comissão semestral de $6 \%$ sobre o valor do crédito aberto, além dos juros de $12 \%$ ao ano. Entendia o autor da ação que aquela comissão era na verdade uma taxa adicional de juros que, somada àquela de $12 \%$ a.a., ultrapassaria o limite estabelecido pelo Decreto 22.626/33 (12\% a.a., cf. arts. $1^{\circ}$ e $\left.2^{\circ}\right)$. Além disso, pediu também em sua réplica à contestação do banco a anulação da cláusula de capitalização semestral de juros, com fundamento no mesmo decreto(art. $4^{\circ}$ ), que só permite a capitalização anual.

A ação foi julgada improcedente em primeira instância, mas procedente no Tribunal de Apelação da Guanabara. $\mathrm{O}$ banco interpôs um recurso extraordinário perante o STF, alegando que havia decisão em sentido contrário do Tribunal de Apelação do Rio Grande do Sul, reconhecendo a distinção entre taxa de juros e comissão, permitindo a cobrança desta última. Alegou também, a existência de decisões que reconheciam a legalidade da capitalização de juros (anatocismo).

O STF, entretanto, não conheceu do recurso, por razões processuais, ou seja, não analisou o mérito da questão.

Em seus comentários, Comparato demonstra que, mesmo sem analisar o mérito, o relator Min. Amaral Santos sugere uma solução para o caso baseada na Súmula 121 do STF, segundo a qual "é vedada a capitalização de juros, ainda que expressamente convencionada

Essa tendência do STF, segundo Comparato, ignora completamente a Lei 4595/64, que reestruturou o sistema financeiro nacional, criando o Conselho Monetário Nacional (CMN) e o Banco Central (Bacen). O Decreto 22.626 fora derrogado por aquela lei, cujo art. $4^{\circ}$, em seus incisos VI e IX, conferia competências ao CMN para, respectivamente,

\footnotetext{
${ }^{94}$ RE 65.129 - GB, publ. RTJ 54/24.

${ }^{95}$ Fábio Konder Comparato, "Comentário de Jurisprudência: Abertura de crédito - nulidade de cláusula contratual”, $R D M 3,1971$, p. 59-62.
} 
disciplinar o crédito e limitar taxas de juros e comissões. Esses incisos, segundo Comparato, seriam "autênticas normas em branco", cujo conteúdo deveria ser preenchido pelo CMN - uma técnica legislativa do direito econômico. O CMN teria, assim, atribuições “quase-legislativas", expressão consagrada no direito norte-americano.

Somente cinco anos após essa decisão, em 1976, foi editada a súmula 596, reconhecendo a derrogação do decreto de Getúlio. A nova súmula pode ser entendida como um reconhecimento implícito da competência normativa das autoridades monetárias. ${ }^{96} \mathrm{O}$ STF passou a aceitar, portanto, que o $\mathrm{CMN}$ e o Bacen editassem normas sobre taxa de juros, sua capitalização, cobrança de comissões, e qualquer outro aspecto da concessão de crédito.

Trata-se, efetivamente, de importante momento da história do controle judicial da regulação financeira no Brasil. Todavia, a instauração de uma nova ordem constitucional em 1988 implica uma revisão de toda a jurisprudência. O que se torna passível de questionamento é se o reconhecimento da capacidade normativa de conjuntura do CMN e do Bacen - implícito na súmula 596 - pode continuar sendo aceito, tendo-se em vista o art. 25 do ADCT.

Foi exatamente essa a questão levantada pela Segunda Câmara do Tribunal de Alçada do Rio Grande do Sul, em decisão de $1995 .{ }^{97}$ Segundo o relator, João Pedro Freire, cujo voto foi aprovado por maioria, a Lei 4595/64 não revogou o Decreto 22626/33. A lei da reforma do SFN autorizou o CMN a "limitar" as taxas de juros e comissões:

"A Resolução n 389 do CMN, em verdade, foi que, data venia, abriu a porta da agiotagem oficializada e passou a "interpretar" a lei - como se fosse de sua competência e para tanto tivesse autoridade - mandando que o resto do Brasil lesse o verbo limitar como

\footnotetext{
${ }^{96}$ É a posição de Simone Lahorgue Nunes (Os fundamentos e os limites do poder regulamentar no âmbito do mercado financeiro, dissertação de Mestrado, São Paulo, Faculdade de Direito da USP, maio de 1999, p. 113).

${ }^{97}$ Apelação cível 195.168.299 - Gramado, acórdão reproduzido em Nelson Eizirik (org.), Instituições financeiras e mercado de capitais: jurisprudência, $2^{\circ}$ tomo, vol. 1, Rio de Janeiro, Renovar, 1998, pp. 211 e SS.
} 
sinônimo de liberar, no que recebeu o beneplácito, infelizmente, do próprio STF, no editar a Súmula ${ }^{\circ}$ 596." 98

Em sua crítica veemente, o relator afirma que o Brasil "conviveu ordeira e harmoniosamente por mais de meio século" com o Decreto 22626 e o art. 1062 do antigo Código Civil (que estabelece o limite legal de 6\% a.a. para as taxas de juros). Segundo ele, a Resolução CMN 389, de 15/09/76, foi instrumento dos "políticos representantes não da população, mas dos donos dos grandes conglomerados financeiros, com a assessoria prestimosa dos burocratas daquele egr. Colegiado". 99

Segundo a decisão, o art. 25 do ADCT teria provocado a revogação de todos os dispositivos de delegação ao CMN contidos na Lei 4595/64, o que implicaria nÃo mais ser correta a aplicação da Súmula 596.

Um ano depois, a Quarta Câmara do mesmo tribunal proferiu decisão semelhante. ${ }^{100}$ Sua ementa não poderia ser mais taxativa:

"Com o advento da Constituição Federal de 1988, por força do art. 25 do ADCT, revogadas ficaram todas as instruções normativas e, de resto, o próprio poder normativo, em matéria de competência legislativa do Congresso Nacional. Por conseguinte, o poder normativo a respeito de juros bancários que a Lei 4595/64 concedia ao Conselho Monetário Nacional restou revogado. A única lei federal limitativa de juros é a Lei da Usura que hoje regra os contratos de toda a sociedade, inclusive os bancários." ${ }^{101}$

Para o relator, Márcio Oliveira Puggina, a Súmula 596 consubstanciou uma interpretação "iníqua" da Lei 4595/64, que ele erroneamente chamou de "Lei de Mercado de Capitais". A linha argumentativa é idêntica ao acórdão referido anteriormente.

\footnotetext{
${ }^{98}$ Reproduzido em Nelson Eizirik (org.), Instituições financeiras e mercado de capitais: jurisprudência, ob. cit., p. 213.

${ }^{99}$ Ibid., p. 214.

${ }^{100}$ Apelação cível 196.004.204 - Porto Alegre, acórdão reproduzido em Ibid., pp. 219 e ss.

${ }^{101}$ Ibid., p. 220.
} 
Entretanto, o STF e o STJ têm admitido, ainda que implicitamente, a capacidade normativa de conjuntura das autoridades monetárias, o que significa que todas as decisões "anti-usura" são e serão reformadas em Brasília.

Uma ressalva, neste ponto, deve ser feita, com relação ao tratamento que o STJ dá à questão da capitalização dos juros. Embora, por um lado, seguindo a súmula 596 do STF, o Tribunal reconheça a competência do CMN para tratar da matéria e que o limite de $12 \%$ que a Lei de Usura estabelece não se aplica mais às instituições do sistema financeiro, por outro, assume uma surpreendente postura restritiva em relação à capitalização de juros, afirmando que ela somente é possível nos casos em que há autorização expressa de lei. Sem essa autorização legal, ela seria vedada, ainda que pactuada pelas partes - conforme a súmula 121 do STF. O art. $4^{\circ}$ do Decreto 22626/1933 continuaria, portanto em vigor, não havendo a possibilidade de o CMN editar regra permitindo a capitalização. ${ }^{102}$ Tome-se o exemplo do crédito rural, disciplinado pelo Decreto-lei 167/67, cujo art. $5^{\circ}$ admite a capitalização, quando expressamente pactuada. ${ }^{103}$

Esse entendimento foi ampliado para o crédito comercial e industrial, dando origem à súmula 93 do STJ:

Súmula 93: A legislação sobre cédulas de crédito rural, comercial e industrial admite o pacto de capitalização de juros.

Embora a exigência de lei específica para a permissão do anatocismo seja uma restrição à competência normativa do $\mathrm{CMN}$, a tendência da jurisprudência do Tribunal no sentido de interpretar as leis favoravelmente àquela prática ameniza essa restrição. A jurisprudência do STJ consubstancia, na verdade, uma relativização da Súmula 121 do STF, segundo a qual "é vedada a capitalização dos juros, ainda que expressamente convencionada".

\footnotetext{
${ }^{102}$ Recurso Especial (RESP) 124780/RS, publ. DJ de 25/08/97, p. 9394.

${ }^{103}$ Agravo Regimental no Agravo de Instrumento (AGA) 149493/RS, RESP 142.794/RS, RESP, Agravo Regimental na Medida Cautelar (AGRMC) 1494/GO, AGA 119.568/RS, RESP 93.376/RS, RESP 57.442, RESP 115.048/RS.
} 
Embora não abordem expressamente a questão do art. 25 do ADCT, as decisões do STJ reconhecem parcialmente as competências normativas que a Lei 4595/64 atribuiu ao CMN. São decisões importantes porque garantem ao mercado financeiro a tão desejada segurança jurídica, abalada por decisões de primeira e segunda instâncias que contestam aquelas competências. É necessário, portanto, prestar-se atenção a esta ambigüidade da jurisprudência do STJ.

Ela não consagra uma competência normativa absoluta do CMN, ou melhor dizendo, ela não afirma existir uma reserva de regulamento em matéria de juros. ${ }^{104} \mathrm{Se}$ o Congresso quiser limitar os juros em contratos específicos pode fazê-lo, sem que isso signifique uma invasão da competência do CMN. É o que acontece no exemplo já citado do mútuo rural. Do ponto de vista dogmático, o STJ não desenvolveu uma fundamentação para essa posição. O Congresso continua competente para legislar sobre os juros porque a competência do CMN é resultado de uma delegação legislativa que pode ser revogada ad nutum, ou porque as atribuições daquele órgão são expressão de poder regulamentar próprio de órgãos executivos, e que podem, portanto ser desautorizados por lei específica?

Sem oferecer uma construção dogmática clara sobre o poder normativo de conjuntura do CMN e adotando, ao mesmo tempo, o entendimento da súmula 596 do STF e uma versão mitigada da vedação do anatocismo -- súmula 121 do STF, a jurisprudência do STJ termina por não oferecer, de forma satisfatória, ao mercado financeiro, a segurança jurídica pela qual ele tanto anseia. Permanece, igualmente, sem uma solução formal clara, a tensão entre os cânones do direito público brasileiro e a necessidade estrutural de uma regulamentação conjuntural do mercado financeiro.

Mesmo quando reconhece claramente e sem nenhuma objeção a competência normativa do CMN, o STF não explicita os limites de seu exercício. Foi o que ocorreu, por exemplo, no Caso Ourobraz, de 1999. ${ }^{105}$ A Ourobraz S/A Comércio Importação e Exportação operava no mercado financeiro desde setembro de 1981, captando recursos de terceiros para investimento em ouro ou em certificados de depósito do metal. Em 1987, o CMN editou a Resolução 1429, que considerou aquela atividade privativa de instituição

\footnotetext{
${ }^{104}$ No mesmo sentido, RESP 209.109/RS, RESP 169.440/RS, RESP 163.791/RS, RESP 128.938/RS, RESP 149.477/RS, RESP 164.935/RS, RESP 122777/MG, RESP 31805/RS.

${ }^{105}$ STF, RE 242.550/DF, RTJ 173/1005, relatado pelo Min. Ilmar Galvão.
} 
financeira e condicionada a autorização do Bacen. A Ourobraz recorreu ao Judiciário para contestar a resolução e o caso chegou ao STF como um recurso extraordinário. Em seu sucinto voto, o relator, Min. Ilmar Galvão, confirmou a legalidade e a constitucionalidade da Resolução 1429. Depois de se referir ao art. 192 da Constituição, afirmou que a Lei 4595/64, especificamente em seu trecho relativo à competência do CMN para fixar normas sobre política cambial e compra e venda de ouro, fora recebida pela nova Constituição. O trecho recepcionado era o fundamento legal da Resolução 1429.

Esse reconhecimento da competência normativa do $\mathrm{CMN}$, acolhido por unanimidade pela Primeira Turma do STF no Caso Ourobraz, por si só já seria muito importante. Há, porém, um aspecto adicional que torna esse caso ainda mais relevante. Em seu voto, o Min. Ilmar Galvão transcreve trechos do voto do relator do caso no TRF da Primeira Região, que não somente reconhecera a competência normativa do CMN, mas também a ela se referira explicitando o fundamento de delegação:

"Não há que se falar em ilegalidade, se ambas as resoluções foram baixadas ao amparo de competência expressamente delegada pela Lei 4595/64." 106 (Grifei).

Não sendo absoluto o princípio da liberdade de iniciativa, a atividade econômica pode ter seu exercício limitado por uma Resolução do CMN, pois ela se fundamenta na delegação promovida àquela autarquia pela Lei 4595/64. Em seu voto. O Min. Ilmar Galvão parece adotar esse fundamento - nenhuma palavra sobre o art. 25 do ADCT, nem sobre a separação dos poderes. Nenhuma objeção à "delegação" de competência para a autarquia. Por unanimidade, a Primeira Turma do STF confirma a decisão do TRF preocupando-se exclusivamente com questões de duas ordens: (i) a natureza financeira, e não mercantil, da atividade; (ii) a ausência de violação à livre iniciativa.

Essa decisão do STF mais uma vez deixa obscura a solução formal para os problemas do fundamento e dos limites do poder normativo do CMN.

\footnotetext{
${ }^{106}$ RTJ 173:1008. A outra resolução envolvida no caso é a 1428/87, que autorizou instituições financeiras a praticar compra e venda no mercado físico de ouro.
} 
Em dezembro de 1987, o STF julgou um dos mais importantes casos envolvendo o reconhecimento dos poderes normativos do CMN e do BCB: o Conflito de Atribuições $n^{\circ}$ $35-1 .{ }^{107} \mathrm{O}$ caso dizia respeito à decisão de um juiz estadual do Rio de Janeiro que, a pedido do Ministério Público, concedera uma medida liminar limitando a cobrança de tarifas bancárias e de juros por parte de vários bancos (Bradesco, Itaú, Unibanco, Real e Nacional). Na petição inicial da ação civil pública, a Curadoria de Justiça dos Consumidores do MP expressamente afirmou que estava pedindo ao Judiciário que regulasse as relações de Direito Privado entre bancos e consumidores. Os dez itens do pedido, todos acatados pelo juiz, impressionam pela sua amplitude.

Sob pena de multa diária e prisão administrativa dos membros dos conselhos de administração dos bancos, aos réus foram impostas proibições e limitações relativas à capitalização de juros, à cobrança de juros de mora, de multa contratual, de taxas de cadastro, de comissão de permanência, de taxa de fornecimento de garantia de cheques. Em relação à linha de crédito do cheque especial, aos bancos foi vedada a cobrança de taxas de juros superiores às correções monetárias das OTNs mais 7\% ao ano. Este último limite só poderia ser ampliado cinco anos após o trânsito em julgado da sentença. Alegando a necessidade de uma "intervenção urgente, porém firme e serena do Poder Judiciário", diante do "momento de intranqüilidade social e econômica vivenciado pela nação brasileira" 108 , o juiz sustentou sua competência para regular o mercado financeiro:

"No que tange à previsão de taxas e limites máximos de juros nos contratos financeiros com as instituições bancárias, ainda que a autoridade administrativa, com base em permissivo legal, possa dispor de forma discricionária, não poderiam as situações concretas das lesões aos direitos individuais ser subtraídas da apreciação da Justiça. Não que o Poder Judiciário pretendesse regular matéria das atribuições do Poder Executivo, mas porque, se as normas (imperativas, atributivas ou permissivas) dos órgãos do Poder Executivo, de si acarretam lesões aos direitos das pessoas, quando na realidade as autoridades deveriam impedir práticas abusivas e por isso nocivas aos consumidores, nada impede, muito ao contrário, provocado pelo Ministério Público em seu munus tutelar dos interesses coletivos, o

\footnotetext{
107 STF, C.A. 35-RJ, Rel. Min. Sydney Sanches, D.J.U. 01.12.89, Ementário 1565-1.

${ }^{108}$ Trechos transcritos no Relatório do C.A. 35-1, p. 43.
} 
Poder Judiciário deve regular as relações de direito privado, em matéria econômica, entre os consumidores e, (no caso em tela) os suscitantes" (grifos no original). ${ }^{109}$

O trecho citado, embora contraditório - afirma, ao mesmo tempo, que o Judiciário não pretende regular, mas deve regular -, deixa claro o sentido que o juiz atribui ao seu papel de controle do $\mathrm{CMN}$ e do BCB. Ele reconhece o poder normativo desses órgãos, mas registra a sua omissão em utilizá-lo para impor limites aos bancos e defender os direitos dos consumidores. Na sua avaliação, se o regulador financeiro não tabela os juros, o Judiciário deve fazê-lo, assumindo, assim, um papel ativo na regulação financeira. A atuação reguladora do Judiciário é entendida aqui como uma forma excepcional - dada a "intranqüilidade social e econômica"- de cumprimento da sua função de defesa de direitos. Trata-se, aqui, não da forma clássica de defesa de interesses individuais, mas da ampla proteção de interesses difusos, com técnicas introduzidas no direito processual brasileiro pela Lei 7.347, de julho de 1985 .

O C.A. 35-1 revelou uma série de tensões. Elas aparecem claramente ao longo das várias páginas do parecer da Procuradoria-Geral da República transcritas no voto do Relator, Min. Sydney Sanches. ${ }^{110}$ Considerando-se que o parecer foi adotado integralmente pelo relator, ${ }^{111}$ pode-se afirmar que essas tensões foram incorporadas ao fundamento da decisão do Tribunal - o que a torna ainda mais rica em termos de reflexão e definição sobre os poderes normativos do CMN e do BCB.

Em primeiro lugar, o caso é um exemplo de como um instrumento de controle democrático - a ação civil pública - pode tecnicamente viabilizar uma atuação judicial tão ampla que, pelo alcance da coisa julgada, sem se despir da sua natureza de prestação jurisdicional, provoca na prática os efeitos de um exercício de uma autêntica função normativa pelo Judiciário. Ao competir, no campo da regulação financeira, com os poderes do $\mathrm{CMN}$ e do BCB, essa forma de regulação judicial em nome da defesa dos direitos coletivos pode ser profundamente desestabilizadora do sistema econômico. A segunda tensão, derivada da estrutura formal da ação civil pública, verifica-se entre o caráter amplo

\footnotetext{
${ }^{109}$ Transcrito no Relatório do C.A. 35-1, p. 46.

${ }^{110}$ C.A. 35-1, pp. 55-64.

${ }^{111}$ C.A. $35-1$, p. 29.
} 
da atuação jurisdicional e a separação dos poderes. Em terceiro lugar, a ampla forma de controle democrático inaugurada pela ação civil pública desafiou, no caso concreto estudado, o princípio federativo: na medida em que a política monetária e creditícia é atribuição constitucional privativa da União, como poderia a Justiça Estadual do Rio de Janeiro - ao invés da Justiça Federal - tabelar as taxas de juros?

O STF enfrentou essas tensões em meio a uma grande divergência entre seus ministros. A decisão final, por maioria apertada de votos, reconheceu a existência de um conflito de competências e afirmou os poderes do $\mathrm{CMN}$ e do $\mathrm{BCB}$, mantendo assim nas mãos da burocracia especializada a gestão racional do crédito, restringindo o alcance do seu controle judicial via ação civil pública.

Em seu voto vencedor ${ }^{112}$, o Min. Relator Sydney Sanches parte da distinção entre, de um lado, a criação de direito material, de normas genéricas de conduta, que seriam de competência - "em princípio" - do Legislativo, e, de outro, a declaração do direito, a prestação jurisdicional, própria do Judiciário ${ }^{113}$. Argumenta que a decisão judicial contestada constituiu um "exercício indevido de poder normativo delegado a órgãos administrativos" (grifei) ${ }^{114}$, para concluir que (i) o conflito de atribuições é "evidente", e (ii) que a competência é do $\mathrm{CMN}$ e do $\mathrm{BCB}^{115}$. Sua linha de argumentação procura delimitar o alcance do controle judicial via ação civil pública afirmando que a proteção dos interesses difusos deve se basear em direito material preexistente à decisão do juiz. Seu voto tem ainda um outro elemento que deve ser levado em consideração. Ao conhecer parcialmente do conflito de atribuições, o Min. Sydney Sanches admitiu que o pedido cumulado de condenação a devolver aos clientes todos os valores indevidamente pagos era compatível com a atividade jurisdicional. Deve-se ressaltar aqui o caráter eminentemente processual dessa decisão: o STF não afirmou que os valores deveriam ser devolvidos aos correntistas, mas simplesmente decidiu que essa forma de controle pode ser feita pelo Judiciário, ao contrário da estipulação de normas genéricas de conduta para o setor financeiro.

\footnotetext{
${ }^{112}$ C.A. 35-1, pp. 49-68. Votaram com o Relator os Ministros Carlos Madeira, Octavio Gallotti, Francisco Rezek e Oscar Corrêa.

${ }^{113}$ Id. p. 65.

114 Id. p. 65.

115 Id. p. 67.
} 
A divergência em relação à tese vencedora foi desenvolvida no voto vencido do Min. Moreira Alves, para quem "no caso, nem o Banco Central nem o Juiz têm atribuições administrativas para que possa dar-se o conflito: aquele tem atribuição legislativa decorrente de delegação e este tem o poder jurisdicional de decidir, concedendo ou negando, a liminar requerida" 116 (grifei). Tanto no trecho transcrito como no breve debate que se segue às suas primeiras palavras, o Min. Moreira Alves deixa claro que sua discordância com o Relator diz respeito à estrutura formal da ação civil pública. Para Moreira Alves, a admissão de ação na defesa de interesses difusos necessariamente confere à decisão judicial um alcance de tal ordem que leva à equivocada impressão de que o juiz estaria legislando, quando, na verdade, ele está exercendo uma forma especial de atividade jurisdicional. Em termos estritamente técnico-jurídicos, seria inconsistente contestar a decisão do juiz do Rio de Janeiro por meio de um conflito de atribuições. O correto para tanto seria utilizar os meios processuais próprios. ${ }^{117}$

Com o julgamento desse conflito de atribuições, o STF teve uma excelente oportunidade para discutir o poder normativo do CMN e do BCB. Em nenhuma outra decisão o Tribunal se pronunciou tão claramente sobre a "delegação legislativa" "118 ou sobre o "poder normativo delegado" 119 para o CMN e o BCB. A grande divergência verificada entre os Ministros foi relativa à natureza da decisão judicial contestada, no contexto de um debate formal sobre a tutela jurisdicional dos interesses difusos.

Dos dez Ministros que expressaram seu entendimento, somente o Min. Célio Borja rejeitou a idéia de que os poderes normativos do $\mathrm{CMN}$ e do BCB decorrem de delegação. Ao contrário do que possa parecer, porém, sua recusa da tese da delegação não significou uma condenação daqueles poderes. Muito pelo contrário, o Ministro votou pelo conhecimento in totum do conflito de atribuições e pela incompetência do juiz do Rio de

\footnotetext{
${ }^{116}$ C.A. $35-1$, p. 69.

117 Acompanharam a argumentação do Min. Moreira Alves os Ministros Aldir Passarinho, Néri da Silveira e Djaci Falcão.

${ }^{118}$ Em seu sucinto e objetivo voto, o Min. Moreira Alves utiliza a expressão três vezes (C.A. 35-1, pp. 69 e 72).

${ }^{119}$ Voto do Min. Sydney Sanches, no qual a expressão aparece duas vezes (C.A. 35-1, pp. 65 e 67). O parecer da Procuradoria-Geral da República, acolhido integralmente pelo Relator, também afirma expressamente que a autoridade monetária exerce "delegação legal" (p. 53). O voto vencido do Min. Aldir Passarinho faz referência “às leis baixadas pelo Conselho Monetário Nacional ou pelo Banco Central” (p. 100).
} 
Janeiro. A linha argumentativa que possibilitou ao Ministro, ao mesmo tempo, rechaçar a delegação legislativa e afirmar os poderes normativos das autoridades monetárias, seguiu os seguintes passos ${ }^{120}$ : (i) o sistema de governo brasileiro está baseado numa rígida separação de poderes (art. $6^{\circ}$ da CF de 67); (ii) vigora no Brasil a regra da indelegabilidade das atribuições (parágrafo único do mesmo art. $6^{\circ}$ ); (iii) a mudança de função do Estado levou-o a "tutelar as relações econômicas de natureza privada, através do exercício dos chamados poderes regulatórios", tornando obsoleto o "cartesianismo da classificação exaustiva das funções do Estado, fundado na suposição de que todas as atividades e atos dos poderes públicos inserir-se-iam em uma de suas três espécies"; (iv) esses novos poderes regulatórios, assumidos pela Administração Pública, têm ao mesmo tempo natureza normativa e de poder de polícia; (v) as competências que a Lei 4.595/64 atribuiu ao $\mathrm{CMN}$ e ao BCB têm essa natureza regulatória; (vi) sendo próprios da Administração, não podem ser considerados como resultado de delegação legislativa do Congresso, pois "não se pode dar a outrem o que não se possui"; (vii) sendo o STF o "árbitro dos litígios entre os poderes do Estado", ele não deve permitir que o Judiciário exerça "atividade típica da administração da política monetária e creditícia, sob a modalidade regulatória”, ou seja, que um juiz, desrespeitando o princípio da separação dos poderes, "exerça atribuições de outro poder da República”. Fica claro, portanto, que a tese contrária à delegação legislativa foi minoritária no julgamento.

Uma análise global dos distintos fundamentos e conclusões dos votos dos ministros demonstra que todos eles têm algo em comum: reconhecem os poderes normativos do CMN e do BCB, no contexto de um regime constitucional - o da EC 1/69 - que veda expressamente, seguindo a tradição brasileira, a delegação de poderes. Essa vedação sequer foi abordada nos votos, com a exceção do Min. Célio Borja. Este último, mesmo assim, ao desenvolver o tema, o fez com a intenção de construir uma argumentação que permitisse às autoridades monetárias o exercício de poderes normativos, apesar da vedação constitucional da delegação.

A tese vencedora, que restringe o controle judicial sobre os poderes regulatórios do CMN e do BCB, contribui para a consolidação de um modelo de separação dos poderes

\footnotetext{
${ }^{120}$ Voto de vista do Min. Célio Borja (C.A. 35-1, pp. 75-90).
} 
que reserva para a Administração Pública decisões políticas - no sentido de policy fundamentais relativas à gestão contemporânea da moeda e do crédito. Essa idéia de uma esfera de tomada de decisões que não pode ser submetida ao controle democrático do Ministério Público e do Judiciário foi exemplificada de forma enfática pelo Min. Francisco Rezek, que acompanhou o voto vitorioso do relator:

"Figuro a situação seguinte: amanhã o curador de interesses difusos, no Rio de Janeiro, dirige-se a uma das varas cíveis da capital, com toda a forma exterior de quem pede a prestação jurisdicional, e requer ao juiz que, em nome do bem coletivo, exonere o Ministro da Fazenda e designe em seu lugar outro cidadão, cujo luminoso curriculum viria anexo."121

Outro aspecto importante da tese vencedora diz respeito ao abandono sutil de uma visão formalista do processo e do controle judicial. Se fosse seguido à risca o rigor lógicoformal do argumento do Min. Moreira Alves, a atuação efetivamente reguladora do juiz do Rio de Janeiro deveria ser vista simplesmente como uma prestação jurisdicional diferente, mais ampla que a usual, mas permitida pela lei que criou a ação civil pública. Esse formalismo foi expressamente rechaçado pelo Min. Rezek:

"Não é o fato de alguém dirigir-se ao foro que indica, a meu ver, que este alguém esteja pedindo a prestação jurisdicional, e sim o exato teor daquilo que se pede."122

O breve debate que ocorreu logo após o início do voto do Min. Moreira Alves dá o tom da divergência: ${ }^{123}$

"Min. Sydney Sanches (Relator): Quer dizer que se a Procuradoria-Geral da República não entrar com a avocatória, essa liminar vai ser cumprida?

"Min. Moreira Alves: Sim, como qualquer decisão judicial o deve ser enquanto não reformada ou suspensa.

“Min. Sydney Sanches (Relator): Os diretores estão sendo ameaçados de prisão.

"Min. Moreira Alves: Isso é outra questão: a de punição por descumprimento de ordem judicial.

\footnotetext{
${ }^{121}$ C.A. $35-1$, p. 96.

${ }^{122}$ Id. ib.

${ }^{123}$ Id., p. 70.
} 
"Min. Francisco Rezek: A liminar não é em prol dos bancos. Ela é em prol dos clientes em geral. E impõe aos bancos um procedimento diverso daquele que resultara da regulamentação do Conselho.

"Min. Moreira Alves: A liminar foi concedida em favor apenas dos clientes desses Bancos, tendo em vista que se trata de ação em defesa de interesses difusos. Portanto, a liminar não se destina a todos os brasileiros, mas somente aos clientes dos Bancos contra os quais a ação foi proposta, o que demonstra que não se trata de medida de ordem geral, mas apenas em favor dos beneficiários da ação em causa proposta na defesa de seus interesses.

"Min. Sydney Sanches (Relator): Mas são milhares...

"Min. Moreira Alves: Isso resulta da admissão de ação na defesa de interesses difusos. E ela é admitida em nosso ordenamento jurídico.”

A tese vencedora no C.A. 35-1 leva-nos a revisitar uma importante decisão do próprio Tribunal: o julgamento do Habeas Corpus 30.355, de 21 de julho de $1948,{ }^{124}$ no qual o tema da delegação legislativa tem centralidade. O habeas corpus fora impetrado em favor de um comerciante condenado por haver vendido carne verde a preço superior ao da tabela da então existente Comissão Central de Preços.

O principal argumento do impetrante foi a inconstitucionalidade superveniente do decreto-lei que tratava do controle de preços e criara os órgãos que o executariam ${ }^{125}$ - com a promulgação da nova Constituição, em setembro de 1946, as delegações legislativas passavam a ser expressamente proibidas pelo art. $36, \S 2^{\circ}$. Ainda segundo o argumento da petição inicial, o tabelamento de preços é matéria própria do Legislativo, que não poderia, portanto, ser delegada à Comissão de Preços. Essa teria sido a consequiência da vitória na Constituinte da doutrina que conferia todo o poder Legislativo ao Congresso, restando ao Executivo um poder regulamentar limitado à fiel execução das leis.

O voto do Min. Castro Nunes, Relator, impressiona pelo seu realismo conjugado com a preocupação hermenêutica - ou seja, demonstra uma aguda sensibilidade em relação à dinâmica da regulação econômica, ao mesmo tempo em que, por respeito à tradição e à ordem jurídica, esforça-se para construir uma doutrina que não leve à desmoralização da

\footnotetext{
${ }^{124}$ Habeas Corpus n ${ }^{\circ}$ 30-355-DF, 21/07/1948, Rel. Min. Castro Nunes (paginação original).
}

${ }^{125}$ Decreto-lei 9.125, de 04.04.1946. 
Constituição de 46, que expressamente vedava a delegação legislativa. O Min. Castro Nunes começa - respeito à tradição - lembrando que o tema da delegação legislativa é velho, e que no Brasil sempre se entendeu, desde o Império, que a proibição era implícita, decorrendo da separação dos poderes. A proibição explícita surgiu com a primeira constituição republicana e se repetira em 34 e 46. Seu segundo passo - justificativa hermenêutica - é sustentar que a interpretação constitucional não pode ter a mesma rigidez daquela das normas de direito comum:

"É sabido que a interpretação constitucional dispõe de possibilidades muito mais amplas do que as consentidas ao intérprete em face das normas ordinárias. E nisso consiste o segredo da longevidade das instituições americanas, velhas de século e meio, e atualizados pela jurisprudência construtiva da Côrte Suprema na revelação de normas insuspeitas à leitura dos textos e que forma a Constituição não escrita, à margem do instrumento constitucional". ${ }^{126}$

Com uma linguagem direta, o Min. Castro Nunes - seu terceiro passo -relativiza a doutrina da vedação da delegação legislativa:

"Se a Constituição, implícita ou explicitamente, declara que o Poder Legislativo não pode delegar suas atribuições, lança uma proibição a ser observada em linha de princípio, sem excluir, todavia, certas medidas a serem adotadas pelo órgão executor no tocante a fatos ou apurações de natureza técnicas dos quais dependerá a incidência ou aplicação mesma da lei”. ${ }^{127}$

A experiência das delegações legislativas e comissões ou conselhos administrativos dos E.U.A. e a própria experiência brasileira são referências usadas para comprovar a adequação de sua tese à nova dinâmica constitucional e à realidade econômica. O Min. Castro Nunes, ao argumentar que o tabelamento de preços via lei formal seria "impraticável", descreve com todas as letras a necessidade daquilo que se tem chamado mais recentemente de capacidade normativa de conjuntura:

\footnotetext{
${ }^{126}$ HC 30.355, pp. 190-191.

${ }^{127}$ HC 30.355, p. 191.
} 
"Nem o legislador poderia prefixá-los, estabelecendo uma tabela insensível às flutuações do mercado e a outros fatores que intervêm no preço das mercadorias e utilidades; nem seria possível, sem comprometer a eficácia das medidas de proteção ao consumidor, a intervenção legislativa para adoção de nova ou novas tabelas - o que tornaria precário e praticamente inútil o controle que se quis estabelecer." 128

O tabelamento deve, na sua visão, "acompanhar pari passu as variações do mercado". A necessidade da edição rápida e flexível de normas que visem à regulação econômica foi igualmente enfatizada pelo Min. Orosimbo Nonato, para quem o combate ao lucro excessivo não poderia ser feito apenas pelo Congresso, pois as leis "rapidamente se tornariam anacrônicas, fatalmente insensíveis às cotações do mercado, às flutuações econômicas, aos fatos de ordem comercial, que se sucedem às vezes com uma vertiginosidade irrastreável, através da longa elaboração das leis pelo Congresso". ${ }^{129}$

Por unanimidade, foi indeferido o pedido de habeas corpus. A decisão significou um claríssimo esforço - de um STF unido numa mesma tese - de adaptação de um importante cânone do direito público brasileiro à nova realidade do capitalismo regulado e do Estado intervencionista brasileiro, como sintetizou o Min. Orosimbo Nonato:

“A Constituição vigente permite ampla intervenção do poder estatal na ordem econômica. Ha, nesse sentido, uma série de providências que marcam, inequivocamente, que ela não adotou - e nem podia adotar - o anacrônico laissez faire, laissez passer, em face da ordem econômica." ${ }^{\text {130 }}$

Devendo a Constituição ser interpretada presumindo-se sua unidade fundamental, dando-se à norma a "plasticidade adequada às necessidades da vida nacional”, não se pode aceitar, continua o Min. Orosimbo Nonato, que "a vedação das delegações” impeça "a repressão constitucional do lucro excessivo". A consciência da gravidade do assunto está presente no seu voto, aparecendo logo no seu início, quando reconhece que o caso envolve o preenchimento de norma penal em branco, preenchimento este que "tem avultações de

\footnotetext{
${ }^{128} \mathrm{HC} 30.355$, p. 193.

${ }^{129}$ HC 30.355, p. 197.

${ }^{130}$ HC 30.355, p. 197.
} 
ato legislativo". O realismo explícito de seu voto - "[d]elegações sempre existiram" lembra que a extensão do conceito de regulamento fora a saída encontrada nos julgados antigos para acomodar essa necessidade prática. Ao criticar a escola que não faz uma distinção substancial entre lei e regulamento, porque ela levaria à indistinção entre Poder Executivo e Poder Legislativo, Orosimbo Nonato está na verdade reforçando a estratégia segundo a qual a construção doutrinária a ser seguida deveria mesmo ser a da aceitação da delegação legislativa, não obstante a expressa proibição constitucional do art. $36, \S 2^{\circ}$.

Esses importantes casos demonstram como o STF, interpretando constituições que vedavam expressamente a delegação de poderes, adotou a delegação legislativa como fundamento do poder normativo do CMN e do BCB. No HC 30.355, a delegação é expressamente justificada vis-à-vis a vedação constitucional por meio de um raciocínio principiológico e teleológico. No C.A. 35, a delegação é dada como certa pela decisão, sem que se justifique sua constitucionalidade. Ambos os casos, entretanto, têm em comum (i) o fato de serem omissos em relação à hipótese de mutação constitucional e (ii) a ausência da definição de critérios para o controle judicial dos limites da delegação e do poder normativo dela decorrente.

O reconhecimento dos poderes normativos da burocracia pelo STF vem, portanto, desacompanhado dos critérios para o seu controle para o qual não se define qualquer critério, nem substantivo nem procedimental.

\section{Controle judicial e participação democrática}

Nenhum dos casos até aqui analisados tratou expressamente dos mecanismos decisórios do $\mathrm{CMN}$ e do $\mathrm{BCB}$, nem da composição desses órgãos. Como referido no capítulo anterior, a lei geral de processo administrativo federal trata exclusivamente dos princípios dos procedimentos relativos ao contencioso administrativo. ${ }^{131}$ Ela não traz nenhum mecanismo de controle democrático ou de participação no processo administrativo normativo, como consultas ou audiências públicas. Algumas leis específicas, como a Lei

\footnotetext{
${ }^{131}$ Lei $9.748 / 99$.
} 
Geral de Telecomunicações (LGT), ${ }^{132}$ prevêem a realização de consultas e audiências públicas para permitir que todos os interessados possam apresentar críticas e sugestões sobre a regulamentação de determinadas matérias. ${ }^{133}$ A Lei $4.595 / 64$, importante herança da nossa modernização autoritária, não possui uma previsão análoga.

O processo político de centralização do poder monetário no $\mathrm{CMN}$ e no $\mathrm{BCB}$ que ocorreu durante o Plano Real ${ }^{134}$ foi reforçado por uma alteração institucional relevante: a mudança radical da composição daquele órgão. A medida provisória que criou o Plano Real $^{135}$ (i) reduziu, de dez para três, o número de membros do Conselho; (ii) dele excluiu os presidentes do Banco do Brasil e do BNDES; (iii) nele incluiu o presidente do Banco Central. Essa mudança na composição do Conselho ${ }^{136}$ e seus procedimentos decisórios são sintetizados no quadro $\mathrm{n}^{\circ} 05$.

Na ADIn movida contra a mudança da composição do $\mathrm{CMN},{ }^{137}$ quando já havia ocorrido a conversão da medida provisória reeditada em lei, ${ }^{138}$ o Partido dos Trabalhadores alegou que tamanha alteração do órgão mais importante do sistema financeiro nacional só poderia ser efetuada por lei complementar, nos termos do art. 192 da Constituição. Na inicial, o PT criticou o "viés autoritário"139 da alteração, por ela ter excluído do Conselho e, portanto, do processo decisório, "setores expressivos da vida econômica nacional, inclusive os trabalhadores, instituições financeiras oficiais e órgãos do Poder Executivo cuja participação, com direito a voto, reputa-se essencial para assegurar, àquele órgão,

\footnotetext{
${ }^{132}$ Lei $9.472 / 97$.

${ }^{133}$ Para uma análise recente dos mecanismos de participação pública no proceso administrativo normativo da ANATEL, a partir do modelo de democracia deliberativa de Habermas, ver Paulo Todescan Lessa Mattos, "Regulação econômica e social e participação pública no Brasil”, mimeo, Núcleo Direito e Democracia/CEBRAP, 2004 (baseado na tese de doutoramento do autor, recentemente apresentada à Faculdade de Direito da USP).

${ }^{134}$ Cf. Lourdes Sola e Eduardo Kugelmas, "Estabilidade econômica e o Plano Real como construção política - statecraft, liberalização econômica e democratização", in Lourdes Sola/Eduardo Kugelmas/Laurence Whitehead, Banco Central: autoridade politica e democratização - um equilíbrio delicado, Rio de Janeiro: FGV, 2002, pp. 79-109.

${ }^{135}$ Medida Provisória no 434, de 27.02.1994.

${ }^{136}$ A composição do CMN foi alterada diversas vezes desde a sua criação. O quadro reflete a mudança em relação à composição em vigor imediatamente antes do Plano Real. Essa foi, entretanto, a primeira vez que ocorreu uma mudança tão radical, com a exclusão de todos os integrantes não governamentais - inclusive com a extinção sumária dos mandatos ainda não cumpridos.

137 ADIn 1.312-2-DF (Medida liminar), Rel. Min. Moreira Alves, 19.10.95, D.J.U. 24.11.95, Ementário 1810-02. Disponível [on-line] in http://www.stf.gov.br.

${ }^{138}$ Lei 9.069, de 29.06.95.

139 Conforme relata o despacho do Min. Sepúlveda Pertence, que indeferiu a medida cautelar ad referendum do Tribunal (transcrito no Relatório do Min. Moreira Alves, p. 217).
} 
pautar-se pelo interesse da coletividade, e não apenas do governo." ${ }^{140}$ A argumentação prossegue atacando de frente o problema do controle democrático da burocracia:

"Além disso, atenta contra o interesse público que decisões de enorme importância para o conjunto da sociedade sejam adotadas e implementadas sem o necessário controle social e transparência, em virtude da alegada necessidade de 'autonomia da autoridade monetária"”. ${ }^{141}$

Quadro no 05: CMN - composição e participação pública ${ }^{142}$

\begin{tabular}{|c|c|c|}
\hline Período & Antes do Plano Real & Após o Plano Real \\
\hline Composição & $\begin{array}{l}\text { - Ministro da Fazenda (Presidente) } \\
\text { [na sua ausência, podiam assumir a } \\
\text { presidência o Ministro da Indústria e do } \\
\text { Comércio e, na falta deste, o Ministro do } \\
\text { Planejamento] } \\
\text { - Presidente do Banco do Brasil } \\
\text { - Presidente do BNDES } \\
\text { - } 7 \text { membros nomeados pelo Presidente da } \\
\text { República e aprovados pelo Senado (com } \\
\text { mandato de } 7 \text { anos) }\end{array}$ & $\begin{array}{l}\text { - Ministro da Fazenda (Presidente) } \\
\text { - Ministro do Planejamento } \\
\text { - Presidente do Banco Central }\end{array}$ \\
\hline $\begin{array}{l}\text { Processo } \\
\text { decisório }\end{array}$ & $\begin{array}{l}\text { - Deliberação por maioria de votos } \\
\text { - Quorum exigido de } 6 \text { membros } \\
\text { - Presidente tem voto de qualidade }\end{array}$ & $\begin{array}{l}\text { - Deliberação por maioria de votos } \\
\text { - Em casos de urgência e relevância, o } \\
\text { presidente pode deliberar ad referendum } \\
\text { do Conselho }\end{array}$ \\
\hline $\begin{array}{l}\text { Participação } \\
\text { possível, s em } \\
\text { direito de voto }\end{array}$ & $\begin{array}{l}\text { - Ministro da Indústria e do Comércio } \\
\text { - Ministro do Planejamento }\end{array}$ & $\begin{array}{l}\text { Podem ser convidados pelo presidente: } \\
\text { - Ministros de Estado } \\
\text { - Representantes de entidades públicas } \\
\text { ou privadas }\end{array}$ \\
\hline $\begin{array}{l}\text { Previsão legal de } \\
\text { procedimentos } \\
\text { de participação } \\
\text { pública } \\
\text { (consultas, } \\
\text { audiências } \\
\text { públicas) }\end{array}$ & - Não há & - Não há \\
\hline
\end{tabular}

\footnotetext{
${ }^{140}$ Petição inicial, p. 7.

141 Trecho da inicial transcrito na ADIn 1.312-2-DF, p. 216.

${ }^{142}$ Cf. Lei 4.595/64; Medida Provisória 434/2004; Lei 9.069/95.
} 
O STF indeferiu por unanimidade o pedido de medida liminar. Seu primeiro argumento foi de natureza formal: como o CMN não constava expressamente do texto do art. 192, a dúvida sobre estar ou não sua composição submetida à reserva de lei complementar não permitia a concessão da liminar. O segundo argumento baseava-se num "dado circunstancial, que contra-indica a suspensão cautelar"143: a alteração já era vigente há um ano, desde a primeira edição da medida provisória do Plano Real. O terceiro argumento, a partir da constatação de que a medida provisória já havia sido convertida em lei, é o que mais nos interessa aqui:

\begin{abstract}
“Se a conversão em lei não destrói a alegação básica de ser a matéria reservada à lei complementar, o certo é que elide, pelo menos, um dos fundamentos do requerimento liminar: o de que as alterações no perfil do Conselho Monetário subtraindo-lhe a participação da sociedade civil - são de tal importância que não deveriam ser ditadas sem o necessário controle social. Elas têm hoje o respaldo da legitimidade do Congresso Nacional" (grifei). ${ }^{144}$
\end{abstract}

Aqui, o STF enfrentou, ainda que de forma sumária e provisória, a tensão entre legitimidade e eficiência burocrática. Com o Plano Real, o CMN assumiu o papel estratégico de regular o lastreamento da nova moeda e a sua paridade em relação ao dólar, bem como a forma de o Banco Central administrar as reservas internacionais. ${ }^{145}$ No processo de consolidação do novo padrão monetário, parecia impossível manter ou ampliar mecanismos de participação democrática em processos decisórios que envolviam a definição do próprio valor da moeda. O processo político de centralização do poder monetário não estaria, portanto, completo sem essa alteração institucional que faria do CMN um órgão governamental fechado à participação de representantes da sociedade civil no seu processo decisório. Essa necessidade de insulamento do CMN estava claramente anunciada num documento citado na inicial do PT: a Exposição de Motivos Interministerial $n^{\circ}$ 205/MF/SEPLAN/MJ/MTB/MPS/MS/SAF, que acompanhou a edição da Medida Provisória 542/94. A Exposição ressaltava a necessidade de garantir a

\footnotetext{
${ }^{143}$ ADIn 1.312-2/DF, Despacho do Min. Sepúlveda Pertence, p. 216 (incorporado ao voto do Relator).

${ }^{144}$ Id., p. 223.

${ }^{145}$ Lei $9.069 / 95$, art. $3^{\circ}, \S 4^{\circ}$.
} 
“desejável autonomia da Autoridade Monetária” em relação às pressões políticas e ao próprio sistema financeiro:

"A inclusão de representantes do setor privado distorce o caráter de instituição pública do Conselho, pois envolve partes interessadas em decisões onde deve prevalecer o interesse público e o compromisso com a estabilidade da moeda." ${ }^{146}$

Essa autonomia, ainda segundo a Exposição de Motivos, deveria também isolar o CMN em relação a pressões vindas de setores do próprio Estado "nem sempre sintonizados com a função precípua da Autoridade Monetária, de defender a estabilidade da moeda."147 O objetivo da mudança de composição é claro: "priorizar a gestão monetária e preservar o Real das pressões políticas e econômicas que possam pôr em risco a estabilidade do padrão monetário do país." ${ }^{148}$ Revela-se aqui, com todas as letras, o problema que vem sendo enfrentado ao longo de todo esse trabalho: a gestão tecnocrática da moeda e do crédito não se abre à participação democrática a partir da justificativa de que essa abertura seria contrária ao interesse público. O déficit democrático da regulação financeira seria, paradoxalmente, requisito essencial para o exercício democrático - não capturado por interesses privados organizados - dos poderes normativos delegados à burocracia reguladora.

Para o STF, o problema da legitimidade fora resolvido na medida em que o Poder Legislativo aprovara a conversão da medida provisória do Real em lei. Importante, para a compreensão desse problema, é atentar para o fato de que os requeridos na ADIn 1312-2 são o Presidente da República e o Congresso Nacional. O aspecto mais importante da decisão residiu, portanto, na consideração da seguinte questão: qual deve ser o papel do STF no controle de atos dos demais Poderes que restringem a participação democrática em processos decisórios no interior da burocracia econômica?

A resposta do STF aponta claramente para uma posição de self-restraint. Em primeiro lugar, no que se refere ao aspecto formal de sua argumentação, o Tribunal tornou ainda mais ambígua sua posição em relação ao art. 192 da Constituição. Em outros

\footnotetext{
${ }^{146}$ Trecho da Exposição transcrito na petição inicial, p. 5, disponível [on-line] in http://www.stf.gov.br. ${ }^{147}$ Id., ib.

148 Id., ib.
} 
julgados, como o relativo ao limite constitucional dos juros (ADIn 4), o STF enfatizou a necessidade de se respeitar a vontade do constituinte de submeter a regulamentação do sistema financeiro nacional à reserva de lei complementar. Como pode afirmar, agora, que a mudança da composição do órgão regulador mais importante do mercado financeiro não precisaria se submeter àquela exigência? Dessa forma, o STF sacrifica a coerência em nome de sua postura de não-intervenção nos processos decisórios da burocracia que regula a moeda e o crédito.

Em segundo lugar, o Tribunal deixa de desenvolver quaisquer critérios materiais de controle de constitucionalidade de mudanças institucionais que restringem a participação democrática em processos decisórios. A regra da maioria é adotada como critério legitimador: se uma maioria não qualificada no Congresso aprovou a mudança, ela é legítima. O Tribunal não deve, portanto, atender aos reclamos das minorias que o provocam via ação direta contra a ditadura da maioria ou contra o "autoritarismo" do governo, ainda que tenha sido atropelada a exigência de lei complementar - um claríssimo vício formal de inconstitucionalidade.

Em terceiro lugar, ao fechar as portas para a possibilidade de qualquer participação de pessoas ou entidades não governamentais nas decisões do CMN, o STF ao mesmo tempo fez prevalecer a eficiência burocrática, na tensão entre ela e a legitimidade democrática, mas atribui ao Congresso o papel de resolver essa tensão. Devolve a política aos políticos. Por fim, o STF, como parece ser cada vez mais comum em casos difíceis, não permitiu ainda que sua posição ganhasse status jurisprudencial. Passados sete anos, não há ainda uma decisão de mérito. O serviço de acompanhamento do website do tribunal $^{149}$ revela o seguinte: (i) de dezembro de 1995 a setembro de 2001 - quase seis anos -, os autos ficaram com o Procurador-Geral da República, aguardando parecer; (ii) o parecer foi pela improcedência do pedido; (iii) desde setembro de 2001, os autos estão conclusos com o Relator, que foi substituído em julho de 2003 pelo Min. Joaquim Barbosa. Dessa forma, arrasta-se, há anos, a definição de um dos casos mais importantes sobre o déficit democrático da regulação financeira no Brasil.

\footnotetext{
${ }^{149}$ Disponível [on-line] in http://www.stf.gov.br, [01.05.2004].
} 
É inevitável comparar esse caso com o julgamento da ADIn 2223-7, mediante a qual o Partido do Trabalhadores (PT) sustentou a inconstitucionalidade de alguns artigos da Lei $\mathrm{n}^{\circ}$ 9932, de 20 de dezembro de 1999, que dispunha sobre a transferência de atribuições da IRB-Brasil Resseguros S.A. para a Superintendência de Seguros Privados (SUSEP). Na inicial, o principal argumento do PT foi o de exigência de lei complementar. é o da exigência, estipulada pelo inciso II do art. 192, combinado com o seu caput, de lei complementar para a matéria. ${ }^{150}$ Em sua petição inicial, o PT refere-se expressamente à ADIn 4-7 e ao "tratamento global do sistema financeiro".

Em sua decisão de 13 de julho de 2000, que deferiu a liminar ad referendum do Tribunal Pleno, o Relator, Ministro Maurício Corrêa, fez uma afirmação que, em princípio, induziria à confirmação da tese atacada no presente trabalho:

"O que se assevera é que a Lei $n^{\circ}$ 9932, de 20 de dezembro de 1999, adentrou o campo da autorização e funcionamento dos estabelecimentos de seguro e resseguro, o que somente poderia ocorrer mediante a lei complementar - que esta Corte já entendeu abrangente - e que versará, se algum dia vier a ser aprovada, sobre o Sistema Financeiro Nacional como um grande todo, incluindo seguro, resseguro, previdência e capitalização.. ${ }^{151}$

Em sessão plenária do dia 22 de novembro de 2001, os Ministros Sepúlveda Pertence e Nelson Jobim referendaram a decisão do Ministro Relator no sentido de suspender a eficácia da expressão "incluindo a competência para conceder autorizações" contida no art. $1^{\mathrm{o}}$ da Lei. ${ }^{152}$

\footnotetext{
${ }^{150}$ CF 1988, art. 192: "II - autorização e funcionamento dos estabelecimentos de seguro, resseguro, previdência e capitalização, bem como do órgão oficial fiscalizador;" - tratava-se da nova redação deste inciso, dada pela Emenda Constitucional $\mathrm{n}^{\circ} 13 / 96$, que extinguiu o monopólio estatal da atividade de resseguro. Na novíssima redação, após a Emenda

${ }^{151}$ DJU 01.08.2000.

152 "Art. $1^{\circ}$ As funções regulatórias e de fiscalização atribuídas à IRB-Brasil Resseguros S.A. - IRB-BRASIL Re pelo Decreto-Lei $\mathrm{n}^{\circ}$ 073, de 21 de novembro de 1966, incluindo a competência para conceder autorizações, passarão a ser exercidas pela Superintendência de Seguros Privados - SUSEP".
} 
5. Controle de constitucionalidade, burocracia e democracia deliberativa

O estudo de casos exemplares do STF ajuda a compreender melhor a real dinâmica do direito público brasileiro. Em primeiro lugar, ele demonstra o quão distante dessa dinâmica está a doutrina jurídica predominante no Brasil contemporâneo, de forte caráter liberal, descrita no primeiro capítulo desse trabalho. Muito ao contrário do que essa doutrina apregoa, os poderes normativos da burocracia econômica são confirmados pela jurisprudência constitucional, que tem se demonstrado sensível à necessidade desses poderes para a regulação do mercado financeiro numa sociedade complexa. Considerandose o prestigioso papel que os livros e artigos doutrinários exercem no Brasil, embora o direito real - as normas criadas a partir dos textos normativos e dos dados da realidade seja aquele que emana das decisões do Tribunal, ${ }^{153}$ essa primeira constatação provoca a perplexidade de se perceber a enorme discrepância entre os cânones consagrados nos manuais (law in books) e a realidade do direito brasileiro (law in action), ou seja, entre o discurso jurídico da doutrina predominante e o discurso do direito produzido pelo STF. ${ }^{154}$

A segunda constatação é relativa à forma como, no jogo de competências da constituição-máquina brasileira, desenvolve-se o reconhecimento dos poderes normativos do CMN e do BCB. Não é, de forma alguma, mediante uma clara evolução jurisprudencial. Não há uma orientação coerente, construída de forma consistente ao longo do tempo. O que existe é um conjunto de decisões ad hoc que seguem estratégias formais e informais distintas para lidar com a tensão entre racionalidade formal e material, entre governabilidade substantiva e legitimidade legal-racional, entre eficiência burocrática e legitimidade democrática. Ao invés de interpretação construtiva, mediante uma hermenêutica mais sofisticada e aberta ao sopesamento de princípios jurídicos, o que se percebe é a reação auto-limitadora, expressada em pautas hermenêuticas tradicionais ou em estratégias informais de decisão, que lidam de forma ambígua e contraditória com valores e com pressões dos sistemas político e econômico.

\footnotetext{
${ }^{153}$ Cf. Eros Roberto Grau; "Também a interpretação feita pela ciência jurídica é distinta daquela feita pelos órgãos jurídicos; a interpretação feita pela ciência jurídica não é autêntica; é pura determinação cognoscitiva do sentido das normas jurídicas; não é criação jurídica. [...] Apenas o intérprete autêntico - concluo - é revestido do poder de criar as normas jurídicas" (Ensaio e discurso sobre a interpretação/aplicação do direito, São Paulo: Malheiros, 2002, pp. 78-9).

${ }^{154}$ Cf. Eros Roberto Grau: "Discurso do direito é o discurso prescritivo produzido pelos juízes e tribunais autorizados a dizê-lo. Discurso jurídico é o conjunto dos discursos que usam ou falam do discurso do direito", ob. cit., p. 83.
} 
A terceira constatação é sobre o resultado final de todo esse processo, no que diz respeito ao controle democrático da capacidade normativa de conjuntura. Um primeira interpretação plausível é que, dada a constante instabilidade econômica e institucional do País, o STF tem feito o que é possível: adotar, caso a caso, a estratégia que melhor leve a uma acomodação política do problema, evitando, ao mesmo tempo, (i) uma declaração formal de ruptura com a hierarquia das normas e a separação dos poderes, ou seja, com a legalidade, e (ii) decisões que, pelo bloqueio da ação dos órgãos reguladores, deixariam o Estado de mãos atadas, abandonando os mercados à sua própria sorte. Uma segunda interpretação seria mais crítica, apontando os problemas decorrentes de não se ter desenvolvido uma jurisprudência clara e coerente sobre os limites do poder normativo do $\mathrm{CMN}$ e do $\mathrm{BCB}$. O adiamento de julgamentos de mérito até a perda de objeto das ações e decisões contraditórias em relação ao processo legislativo não contribuiriam para a garantia dos procedimentos necessários para a gênese democrática do direito, ou, em outros termos, para a legitimidade democrática da cadeia de faculdades de estatuir que estão na base da capacidade normativa de conjuntura.

Qualquer interpretação está, obviamente, imbuída de um componente normativo: o modelo de democracia adotado por aquele que avalia o movimento da constituiçãomáquina. Do ponto de vista de um modelo de democracia deliberativa, baseado numa teoria discursiva do direito, o papel da corte constitucional consistiria em garantir a legitimidade do direito mediante o reforço de procedimentos que preservassem ao mesmo tempo a autonomia privada e a autonomia política dos cidadãos, ameaçadas pela ação administrativa estatal que se desenvolve mediante a edição de regras jurídicas por uma burocracia insulada. Como afirma Habermas:

"The intention is to tame the capitalist economic system, that is, to 'restructure' it socially and ecologically in such a way that the deployment of administrative power can be simultaneously brought under control. From the standpoint of effectiveness, this means training the administration to employ mild forms of indirect steering; from the standpoint of legitimacy, it means linking the 
administration to communicative power and immunizing it better against illegitimate power."155

O tipo de controle judicial que o STF tem apresentado em relação aos poderes da burocracia econômica frustra a expectativa do observador e do cidadão que haviam descartado a solução plebiscitária weberiana. Como explicado na parte final do primeiro capítulo, Weber enxergava na liderança carismática - que despontaria no "celeiro" do Parlamento para ocupar o Poder Executivo - o papel de contrabalançar o imenso poder da burocracia na sociedade contemporânea.

$\mathrm{Na}$ perspectiva da democracia deliberativa, a esperança era de que a corte constitucional, mediante uma interpretação construtiva, preservando a coerência do direito, distinguindo princípios de valores, e fundamentando de forma consistente suas decisões, utilizasse sua faculdade de impedir de modo a garantir as condições procedimentais da gênese democrática dos textos normativos no âmbito dos demais poderes e da burocracia reguladora. Essa atuação deveria objetivar a modelagem da constituição-máquina brasileira de forma a criar uma dinâmica mediante o qual o controle do judicial da regulação financeira se transformasse num mecanismo de desobstrução dos canais de participação com vistas à formação democrática de uma vontade geral de modo a levar em consideração todos os interessados, com a prevalência do melhor argumento.

O que se tem visto no Brasil é o oposto disso tudo: ao invés da domesticação do sistema administrativo, com vistas à sua abertura aos canais informais de comunicação política, tem-se a chancela incondicional do Tribunal para que a tecnocracia iluminada cuide do "interesse público". Poder sem responsabilidade, reconhecimento sem controle, eficiência sem legitimidade.

É complexo o resultado da combinação, de um lado, de uma prestigiosa doutrina jurídica que, de forma irrealista e segundo cânones liberais insustentáveis, não reconhece os poderes normativos da burocracia, e, de outro, um controle judicial que, em meio às dificuldades metodológicas, institucionais e estruturais peculiares do controle de constitucionalidade da jovem democracia brasileira, tem sido impedido de se afirmar como

${ }^{155}$ Cf. Jürgen Habermas, Between facts and norms, ob. cit., p. 410. 
um controle democrático efetivo que se contraponha à tendência de burocratização da vida social. Dessa forma, a capacidade normativa de conjuntura da burocracia reguladora do sistema financeiro torna-se apenas mais um meio de resolução de problemas de integração funcional. $^{156}$

Duas ressalvas devem, entretanto, matizar essa conclusão. A primeira diz respeito ao seu alcance: ela aplica-se tão somente à regulação financeira, e não a toda a atuação do Tribunal. Somente um conjunto muito amplo e detalhado de pesquisas sobre várias matérias específicas poderia autorizar um juízo sobre a atuação global do STF - o que foge, portanto, à capacidade e aos objetivos do presente trabalho. A segunda ressalva é relativa ao inégavel papel fundamental que o STF tem desempenhado na história da República, o que é exemplificado pela doutrina que construiu sobre o habeas corpus, ampliando a sua utilização para a defesa de direitos, num tempo em que o mandado de segurança ainda não havia sido criado. ${ }^{157}$ Muitos outros exemplos poderiam ser dados de criações jurisprudenciais sólidas do STF, importantíssimas para a democracia brasileira.

A conclusão do estudo de casos não aponta, pois, para uma crítica fácil, generalizada, de toda a jurisprudência constitucional, até porque o objeto da crítica não é o Tribunal em si, mas o conjunto da constituição-máquina. O que o presente capítulo demonstra é que, no que se refere à capacidade de normativa de conjuntura dos órgãos que regulam o mercado financeiro, a atuação do STF não foi ainda capaz de oferecer uma reação consistente ao problema da legitimidade do poder normativo da burocracia. Conseqüentemente, o problema do déficit democrático desse exercício permanece sem solução.

\footnotetext{
156 "Policies that are adopted in a manner that does not conform to the conditions for the democratic genesis of law are merely cloaked in juridical form. When this occurs, one also loses the criteria by which these policies can be normatively assessed. In the execution of such programs, standards of effectiveness that govern the deployment of administrative power take the place of standards of the legitimacy of legal regulation. In fact, this danger seems to grow as the state is expected to take on an increasing number of tasks. Then the law, having been instrumentalized for political goals and deprived of its internal structure, degenerates in the eyes of an independent administrative system into one more means for solving problems of functional integration - and only for solving such problems." (Jürgen Habermas, ob.cit., p. 429).

${ }^{157}$ Lêda Boechat Rodrigues dedicou à jurisprudência do STF sobre o habeas corpus - para ela, "a maior criação jurisprudencial brasileira" - todo o terceiro volume de sua História do Supremo Tribunal Federal, que abrange o período de 1910 a 1926 (Rio de Janeiro: Civilização Brasileira, 1991, p. 17).
} 


\section{CAPÍTULO IV DIREITO ECONÔMICO E DEMOCRACIA}

1. O falso consenso: a construção dos cânones do direito público brasileiro

Em conferência proferida no dia 18 de setembro de 1959, Seabra Fagundes afirmou que a proibição da delegação legislativa "cria obstáculos à fecundidade do trabalho governamental e leva a distorções na prática da administração, como está acontecendo quando o Presidente da República legisla". ${ }^{1}$ Três anos antes, fora publicada uma outra conferência sua, em que discorria sobre a crise do processo legislativo, a incapacidade deste de produzir normas com rapidez e eficiência. Atacava o conhecido e tão debatido $\S$ $2^{\circ}$ do art. 36 da Constituição de 1946, ${ }^{2}$ defendendo, porém, a sua importância para a independência do Judiciário. Reivindicava, portanto, com base na prática política "de todos os povos", a mudança da Constituição, contra a crença predominante na doutrina jurídica da separação dos poderes:

"No campo das instituições políticas o que vale primordialmente é a funcionalidade, é a eficiência, é a utilidade das fórmulas na sua transplantação à realidade ambiente, e não a harmonia das regras com modelos teóricos."33

A afirmação clarividente de Seabra Fagundes reflete o espírito de uma época. Entre agosto de 1955 e abril de 1956, o Instituto de Direito Público e Ciência Política da Fundação Getúlio Vargas (INDIPO) realizou, no Rio de Janeiro, mesas redondas que tinham como objetivo discutir e propor reformas na estrutura e nas funções do Poder Legislativo, com vistas a uma eventual revisão constitucional. Junto com Seabra Fagundes, participavam dos encontros, presididos por Themistocles Cavalcanti, nomes como João Mangabeira, Nestor Duarte, Gustavo Capanema, Bilac Pinto, Victor Nunes Leal, Barbosa Lima Sobrinho e Hermes Lima, dentre outros, além do presidente da FGV, Luís Simões

\footnotetext{
${ }^{1}$ Apud Bonifácio Fortes, "Delegação legislativa", Revista de Direito Administrativo 62 (1960), p. 369.

${ }^{2} \mathrm{CF} 46$, art. 36, § 20: "É vedado a qualquer dos Podêres delegar atribuições".

${ }^{3}$ Miguel Seabra Fagundes, "Reformas essenciais ao aperfeiçoamento das instituições políticas brasileiras", Revista Forense 163 (1956), p. 13.
} 
Lopes. ${ }^{4}$ Os debates eram sempre realizados a partir de um documento com sugestões prévias elaborado por João Mangabeira, que exercia a função de relator. Os tópicos abrangiam os aspectos mais importantes do Congresso, desde a proposta de extinção do Senado até a delegação legislativa. Foi na última mesa redonda, realizada em 30 de abril de 1956, que João Mangabeira discutiu com o grupo sua proposta de revogação do $\S 2^{\circ}$ do art. 36. Dessa reunião não participou Seabra Fagundes. Os debates mostram claramente como a vedação constitucional da delegação legislativa, ou, de forma mais ampla, de qualquer das funções estatais, era vista como algo anacrônico:

"Bilac Pinto: Sr. Presidente, igualmente estou de acôrdo, em princípio, com a sugestão do Sr. João Mangabeira a respeito da delegação de poderes.

"Sabemos que duas razões principais concorrem para que a delegação de poderes seja atualmente inscrita nas constituições dos países democráticos.

"Em primeiro lugar, o volume da legislação; em segundo o caráter técnico da legislação que cada vez mais se apura em razão da intervenção do Estado na ordem econômica. No caso do Brasil, eu acrescentaria outra razão a justificar a medida em determinadas condições: a pressão sobre o Congresso. Há, no Brasil, grupos de pressão que exercem sôbre o Congresso uma violenta coação."

Bilac Pinto ressalta, entretanto, que também o Executivo está sujeito à influência de grupos de interesse. $\mathrm{Na}$ sua concepção, essa influência poderia ser diminuída com a fixação, pelo Congresso, no ato da delegação, das diretrizes políticas da lei a ser elaborada, exatamente como propunha João Mangabeira. Os debates não deixam de revelar uma crítica contundente à doutrina clássica da separação dos poderes, como no pronunciamento de Themistocles Cavalcanti:

“SR. PResidente: Há muito tempo que defendo a delegação de poderes. Tenho escrito e falado sôbre o assunto. Não tenho a mística do princípio rígido a meu ver errôneamente consagrado na Constituição, com ênfase incompreensível, da independência dos poderes."

\footnotetext{
${ }^{4}$ A transcrição dos debates foi publicada em João Mangabeira (rel.), Estudos constitucionais: Poder Legislativo, Rio de Janeiro: FGV/INDIPO, 1956.

${ }^{5}$ Ibid., p. 91.

${ }^{6}$ Ibid., p. 93 .
} 
O relatório final aprovou a supressão do $\S 2^{\circ}$ do art. 36 , além de sugerir o acréscimo ao $\S 4^{\circ}$ do art. 67 da Constituição de 1946 medidas que incluíam no processo legislativo a possibilidade de delegação legislativa. O debate travado foi muito mais rico e complexo do que o resumo aqui apresentado. Ele abrangia, por exemplo, a distinção entre "autorização" e "delegação" legislativa, e a discussão sobre até que ponto a proposta de João Mangabeira de inovação do processo legislativo configurava uma autêntica delegação legislativa. ${ }^{8}$ Entretanto, o que importa, aqui, é o espírito das mesas redondas, sua abertura para a necessidade de repensar a separação dos poderes e o dogma da indelegabilidade para se viabilizar a atuação do Estado brasileiro - com a preocupação proporcional de garantir a vinculação do Executivo às políticas traçadas pelo Congresso.

Em palestra proferida em 1952, outro participante das reuniões do INDIPO, Carlos Medeiros Silva, após dar exemplos de vários países em que o regulamento fora ampliado ou a delegação legislativa se tornara uma prática, criticou enfaticamente a Constituição de 1946, afirmando que

“o Brasil, com o regime presidencialista, de separação rígida de poderes, em pleno meado do século vinte, constitui uma singularidade. Não admite a delegação de poderes e veda ao poder regulamentar a extensão que êle precisa ter, em face das necessidades sempre crescentes do Govêrno, quanto ao provimento do bem público". 9

Para ele, duas únicas soluções seriam possíveis: ou o conceito de poder regulamentar deveria ser ampliado, ou o texto constitucional deveria ser reformado, para permitir as delegações legislativas. Segundo o autor, esta última opção seria a melhor, do ponto de vista técnico. ${ }^{10}$

\footnotetext{
${ }^{7}$ Ibid., p. 97.

${ }^{8}$ Também aprovada no relatório final, a proposta era a seguinte: (i) a Câmara, com a concordância do Senado, poderia autorizar o Presidente da República a completar um projeto de lei já iniciado no Congresso, mas que continha apenas as normas jurídicas fundamentais ou as diretrizes políticas; (ii) o Presidente completaria o projeto e o devolveria à Câmara; (iii) a Câmara deveria aprovar ou rejeitar a íntegra do projeto, não podendo emendá-lo (ibid., p. 14).

${ }^{9}$ Carlos Medeiros Silva, "O poder regulamentar no direito comparado", Revista de Direito Administrativo 30 (1952), p. 32.

${ }^{10}$ Ibid., p. 33.
} 
Bonifácio Fortes, ao comentar a vedação da delegação legislativa, afirmou que “êste aspecto dogmático é decorrente da reação liberal, demagógica, após a redemocratização". ${ }^{11}$ No mesmo sentido, foi de Afonso Arinos de Melo Franco a mais contundente crítica à vedação constitucional da delegação, ressaltando seu caráter meramente simbólico:

“Êste artigo não é senão a explosão de um recalque antiditatorialista da Assembléia Constituinte, não é senão o gesto de revide desta Casa, fechada traiçoeiramente a 10 de novembro pelo ditador. Êste artigo não tem significado econômico, êste artigo não tem sequer significado jurídico. Êle não é senão a manifestação de uma condenação política, êle não é senão o protesto da consciência legislativa nacional em face das ameaças da espada ou da ditadura."12

Durante os debates constituintes que deram origem ao texto de 1946, a polêmica esteve sempre presente. O problema da governabilidade foi levantado na Constituinte por Hermes Lima: "ninguém pode governar sem funções delegadas". ${ }^{13}$ Agamenon Magalhães e Barbosa Lima Sobrinho posicionaram-se da mesma forma. ${ }^{14}$

Convém voltar ainda mais no tempo e relembrar, neste ponto, o famoso debate entre Waldemar Ferreira e Oliveira Vianna, na década de 30, quando da discussão sobre a criação do poder normativo da Justiça do Trabalho. Em seu parecer sobre o projeto de criação da Justiça do Trabalho, Waldemar Ferreira, de posição liberal, sustentou a inconstitucionalidade daquela competência normativa, na medida em que estender além dos litigantes os efeitos de uma decisão judicial, além de contrariar consagrado princípio do direito processual, implicaria conceder à Justiça um autêntico poder legislativo.

Em sua defesa do projeto, Oliveira Vianna desenvolve uma crítica sarcástica e contundente dos processualistas clássicos, imbuídos de um uma visão individualista do direito e do processo. Mais do que a defesa do projeto, seu texto sustenta o anacronismo da regra da indelegabilidade legislativa:

\footnotetext{
${ }^{11}$ Bonifácio Fortes, "Delegação legislativa", Revista de Direito Administrativo 62 (1960), p. 367.

${ }^{12}$ Diário do Congresso Nacional, 24-II-1959, p. 1296), apud Caio Tácito, “As Delegações Legislativas e o Poder Regulamentar", Revista de Direito Administrativo, 34 (1953), p. 471.

${ }^{13}$ Diário da Assembléia, 17-VIII-46, p. 4176, apud Caio Tácito, ob. cit., p. 471.

${ }^{14}$ Cf. Bonifácio Fortes, ob. cit., p. 368.
} 
"O que a experiência dos povos mais velhos tem verificado é que este princípio, mesmo quando é consagrado explicita e taxativamente nos textos constitucionaes, não póde ter uma applicação muito rigorosa, sob pena de tornar impossível a administração da cousa pública. O mandamento prohibitivo quebra-se em face dos próprios imperativos da prática administrativa. Crea-se - como veremos mais adiante - o dilemma: ou há delegação, ou não há administração possível."15 (Grifos no original).

Para Oliveira Vianna, a obediência cega à letra da constituição não pode prevalecer sobre a busca da eficiência do serviço público, sendo este valor o fundamento para a edição de legislação delegada. ${ }^{16} \mathrm{~A}$ autoridade administrativa poderia ter, assim, poderes que não estavam "nem no texto, nem no pensamento da lei". ${ }^{17}$

A base empírica de seu argumento é a prática da delegação legislativa nos E.U.A. Vianna exalta o pragmatismo da Suprema Corte, que reconheceu e justificou a constitucionalidade da competência legislativa concedida a autoridades administrativas, segundo ele, "um imperativo da própria realidade". ${ }^{18}$

Os exemplos acima mostram como parte importante da doutrina do Direito Público brasileiro sempre defendeu a tese segundo a qual a lentidão e a falta de preparo técnico do Legislativo implicariam a necessidade de intervenção do Executivo, notoriamente em matérias administrativas e econômicas, o que demonstra a dissociação existente entre as necessidades práticas da governabilidade e a norma constitucional que impede o exercício de função legislativa pelo Executivo. ${ }^{19}$

Poderíamos voltar ainda mais no tempo. Encontraríamos, obviamente, firmes objeções ao poder regulamentar. Uma das mais conhecidas era a de Pimenta Bueno, na sua obra clássica em que analisava e ao mesmo tempo fazia a apologia da Constituição do

\footnotetext{
${ }^{15}$ Francisco José Oliveira Vianna, "O problema da delegação de poder”, Revista Forense 72 (1937), p. 224.

${ }^{16}$ É curioso observar a coincidência entre o argumento de Oliveira Vianna e o de Tercio Sampaio Ferraz Jr., resumido na parte 1 do capítulo I: a eficiência da Administração Pública como fundamento da delegação legislativa.

${ }^{17}$ Ibid., 225.

${ }^{18}$ Ibid., 226.

${ }^{19}$ Castro Nunes, "Delegação de poderes", Revista Forense 137 (1951), p. 8.
} 
Império. ${ }^{20}$ Sua exposição é clara. Ao comentar o $§ 12$ do art. 102 da Constituição de 1824, segundo o qual é atribuição do Poder Executivo "expedir os decretos, instruções e regulamentos adequados à boa execução das leis", ele argumentava que o governo não poderia usurpar o poder legislativo, falseando a divisão dos poderes. O regulamento não poderia, portanto (i) criar direitos ou obrigações novas, não estabelecidos pela lei; (ii) ampliar, restringir ou modificar direitos ou obrigações; (iii) ordenar ou proibir o que a lei não ordena ou não proíbe; (iv) suprir lacunas da lei; (v) facultar ou proibir diversamente do que a lei estabelece; (vi) extinguir ou anular direitos e obrigações. ${ }^{21}$

$\mathrm{Na}$ formulação, os regulamentos "são atos, não de legislação, mas de pura execução, e dominados pela lei”:

\begin{abstract}
"São instruções metódicas circunscritas, e não arbitrárias, que não podem contrariar o texto, nem as deduções lógicas da lei, que devem proceder de acôrdo com os seus preceitos e conseqüências, que não têm por fim senão empregar os expedientes acidentais e variáveis, precisos para remover as dificuldades e facilitar a observância das normas legais."22
\end{abstract}

Essa concepção do poder regulamentar, ainda apresentada - século e meio depois pela doutrina predominante no Brasil contemporâneo como incontroversa, sempre foi objeto de importantes debates. ${ }^{23}$ Do o Império até a era Vargas, passando pela primeira Constituição republicana, que não vedava expressamente a delegação, a jurisprudência do STF não era clara a respeito. ${ }^{24}$

\footnotetext{
${ }^{20}$ Cf. Eduardo Kugelmas, "Pimenta Bueno, o jurista da Coroa", introdução à recente reedição da obra do marquês de São Vicente, Direito Público e análise da Constituição do Império, São Paulo: Ed. 34, 2002, pp. 19-49.

${ }^{21}$ José Antonio Pimenta Bueno, Direito Público Brasileiro e análise da Constituição do Império, Rio de Janeiro: Ministério da Justiça e Negócios Interiores, 1957, pp. 230-235 [originalmente publicado em 1857].

${ }^{22}$ Ibid., p. 324.

${ }^{23}$ Cf. Bonifácio Fortes, "Delegação legislativa", ob. cit., pp. 364-377. O autor traça um panorama desse debate, com importantes informações sobre as posições de seus personagens.

${ }^{24}$ O STF declarou a nulidade da reforma do ensino promovida pelo Decreto no 3902/1901, que aprovava o regulamento da Faculdade de Medicina, por considerar essa matéria de competência privativa do Congresso. Entretanto, as reformas do ensino feitas posteriormente, em 1911 e 1915, por meio de delegação, foram consideradas constitucionais (ibid., p. 366).
} 
O debate que ocorreu durante a elaboração da Constituição de 1946 continuou após sua promulgação até sua repercussão no STF gerar o leading case de 1948: o Habeas Corpus 30.355 , que tratava do tabelamento de preços, analisado no capítulo anterior. ${ }^{25}$

Não por acaso, o Ministro Castro Nunes, relator do acórdão, era voz ativa no debate doutrinário. Em 1951, ele publicou um artigo no mesmo volume da Revista Forense que trazia a íntegra do HC 30.355. Em seu texto, ele descreve o dilema enfrentado pelos intérpretes autênticos - "oficiais", na sua linguagem -- da Constituição, diante da vedação constitucional expressa da delegação. Sustenta, aludindo à experiência norte-americana que teria sido melhor que o texto constitucional tivesse sido omisso a respeito, o que daria aos juízes - ele, inclusive - uma maior flexibilidade:

\begin{abstract}
"Ficaria assim aos intérpretes oficiais da Constituição acomodar o princípio às necessidades práticas, no rumo das indicações da doutrina e da experiência de outros povos. Evitar-se-ia o que está ocorrendo e terá de ocorrer - a contradição manifesta e chocante entre as práticas admitidas e o texto constitucional, no seu enunciado literal.".26
\end{abstract}

Os debates em torno da Constituição de 1946 terminaram por confirmar a profecia de um outro ilustre membro das mesas redondas do INDIPO, também membro do Conselho Diretor do Instituto. Victor Nunes Leal publicou, em 1945, um artigo intitulado "Lei e regulamento". ${ }^{27}$

Nesse trabalho, considerado um dos mais importantes sobre o tema, Victor Nunes Leal disseca as normas de competência da constituição de 1937. Assume a posição de Duguit, para quem o regulamento, do ponto de vista substancial, é lei, e, do ponto de vista formal, ato administrativo. A lei, do ponto de vista formal, é toda decisão emanada do órgão que uma determinada constituição designou de legislativo. Já a lei, do ponto de vista material, é ato de formulação de uma regra de direito objetivo ou de organização de

\footnotetext{
${ }^{25}$ O HC 30.355 é apontado como leading case por Alberto Venâncio Filho (A intervenção do Estado no domínio econômico: o direito público econômico no Brasil, Rio de Janeiro: FGV, 1968, p. 232). Eros Roberto Grau aponta a decisão como uma importante referência para a discussão sobre a constitucionalidade da capacidade normativa de conjuntura ("Notas sobre o ordenamento jurídico dos preços", Revista da Faculdade de Direito da UFMG, ano XXV, nova fase, v. 27, n. 22 (1979), p. 155).

${ }^{26}$ Castro Nunes, "Delegação legislativa", Revista Forense 137 (1951), p. 8.

${ }^{27}$ Victor Nunes Leal, "Lei e regulamento", in: Problemas de Direito Público Rio de Janeiro: Forense, 1960, pp. 57-91 (publicado originalmente na Revista de Direito Administrativo 1 (1945).
} 
instituições que devem assegurar o cumprimento daquela regra. Essa tese implica a aceitação de que a hierarquia existente entre lei e regulamento é só de natureza formal.

A Constituição de 37 instituiu, portanto, dois órgãos legislativos: o Parlamento e o Presidente da República. Este, além de poder expedir regulamentos, tinha competência para editar decretos-leis em certas matérias - atribuição originária, independentemente de delegação legislativa. Lei e decreto-lei tinham idêntico valor formal, resultantes que eram do exercício de poder legislativo. A terminologia adotada pela Constituição era a seguinte:

(a) lei constitucional ( $=$ emenda constitucional, art. 174, $\left.\S 4^{\circ}\right)$;

(b) $l e i$ (= leis do Parlamento, arts. 64 a 66; 11 e 74, “a");

(c) decreto-lei (= leis do Presidente, arts. 12, 13, 14 e 74, "b");

(d) decreto, regulamento, regulamento complementar (= regulamentos, arts. 11 e 74 , “a").

Victor Nunes Leal desce a detalhes: como saber se o Presidente promulgou uma norma legal ou uma simples norma regulamentar? A resposta seria dada pela invocação da competência constitucional. Se o fundamento estivesse nos arts. 11 ou 74, "a", seriam meros regulamentos, passíveis de juízo de legalidade. Se o fundamento estivesse nos arts. 12, 13, 14 e 180, seriam normas legais, passíveis de juízo de constitucionalidade.

“A menção da competência é que deve prevalecer, pois lei é ato do poder legislativo e poder legislativo não é, pela atual Constituição, um órgão determinado, mas uma competência constitucional que pertence a mais de um órgão."28 (grifos meus).

O que Victor Nunes Leal sustenta é que a distinção formal entre lei e regulamento não deixou de existir no sistema da Carta de 37:

“Admitir o contrário importa completa subversão da ordem jurídica. O sistema da legalidade, o Estado de direito teria desaparecido entre nós, e o Presidente da República estaria equiparado aos imperantes das antigas monarquias absolutas: Princeps legibus solutus est. Esta conseqüência repugna, porém, não só à

\footnotetext{
${ }^{28}$ Cf. "Lei e Regulamento", in: Problemas de Direito Público, Rio de Janeiro: Forense, 1960a, p. 70.
} 
consciência jurídica moderna, como ainda ao próprio texto constitucional. (grifos meus)."29

Dessa forma, mesmo no caso extremo do exercício total da função legislativa pelo Presidente da República (hipótese do art. 180), a identidade do órgão que expede decretosleis (= leis) e regulamentos não elimina a distinção, pois não é natureza do órgão, mas sim sua competência que está sendo exercida que importa.

Embora limitado à análise da relação entre lei e regulamento à luz da Constituição de 37, a argumentação de Victor Nunes Leal realiza mais do que diz oferecer: ao quebrar a correspondência biunívoca entre Poderes e funções - já que mostra que o Executivo também pode ser órgão legislativo -, desbanca a doutrina tradicional da separação de poderes como separação de funções; não obstante defender que o regulamento é lei em sentido material, consegue justificar a relevância da distinção e da hierarquização - formal - entre lei e regulamento.

Por outro lado, é desconcertante que esse exercício dogmático hermenêutico, respeitoso, segundo o autor, da legalidade e do Estado de Direito, tenha sido motivado pela Constituição do Estado Novo. ${ }^{30}$

Um ano e meio depois, Victor Nunes Leal publica um outro trabalho não menos surpreendente: "Delegações legislativas",31, também clássico na literatura do Direito Público brasileiro. Nesse texto, prevalece a preocupação com as questões que surgem com a transição do regime autoritário para o democrático. Ele escreve em meio aos trabalhos da Assembléia Constituinte e prevê que o novo texto estipulará a proibição das delegações legislativas $^{32}$, resgatando a regra da Constituição de $34\left(\operatorname{art.} 3^{\circ}, \S 1^{\circ}\right)$.

Lembra que as delegações legislativas foram objeto de constantes debates no Império e na Primeira República, cujas constituições eram omissas a respeito, mas

\footnotetext{
29 "Lei e Regulamento", ob. cit., p. 71.

${ }^{30}$ Deve-se lembrar que o art. 187 da Carta de 37 determinava a realização de um plebiscito, o que nunca aconteceu.

${ }^{31}$ Victor Nunes Leal, "Delegações Legislativas", in Problemas de Direito Público, Rio de Janeiro: Forense, 1960, pp. 92-108 (publicado originalmente na Revista de Direito Administrativo 5 (1946)).

${ }^{32} \mathrm{O}$ que terminou realmente acontecendo. A nova Constituição abrigou a regra em seu art. $36, \S 2^{\circ}$ : "É vedado a qualquer dos Podêres delegar atribuições".
} 
terminaram por serem aceitas pelo costume político. Segundo o autor, a jurisprudência do Supremo Tribunal Federal na vigência da constituição de $1891^{33}$ inclinou-se pela nulidade da delegação, mas deu uma interpretação extensiva ao poder regulamentar do Presidente da República. ${ }^{34}$ Cita três acórdãos, cujo argumento principal pode ser sintetizado da seguinte forma: (a) 1915: o exercício do poder regulamentar não implica delegação legislativa; (b) 1921: o poder regulamentar é amplo, e pode inovar para sanar qualquer lacuna da lei; (c) 1923: o decreto regulamentar é ato próprio e autônomo, independente de autorização do Congresso, que "não pode dar o que não tem e exatamente a quem tem". 35

Entretanto, a lembrança do Estado Novo e o receio do recrudescimento autoritário levariam os constituintes a optar pela vedação da delegação legislativa. A delegação, para a maioria dos constituintes, aumentaria o risco de ocorrer a hipertrofia do Poder Executivo. Victor Nunes Leal ataca esse argumento:

“O raciocínio não é, porém, completamente verdadeiro, porque consiste em tomar a parte pelo todo, o acidental pelo essencial. As delegações legislativas, sobretudo as delegações amplas, nunca foram causa ou fundamento da hipertrofia do executivo. Ou são efeito dessa hipertrofia, ou não passam de um dos muitos meios através dos quais se manifestam os fatôres sociais e políticos que conduzem aos regimes autoritários. Quando um parlamento se serve de delegação legislativa para agigantar o executivo, renunciando simultâneamente às suas próprias prerrogativas, é que as condições gerais da vida política chegaram a um ponto deplorável. Com ou sem a possibilidade das delegações, não faltarão, em tal hipótese, os meios adequados a favorecer as ambições absolutistas do executivo., ${ }^{\text {36 }}$

${ }^{33}$ A Constituição de 1891 não proibia expressamente a delegação, mas a doutrina e o STF assumiam esta premissa, sem qualquer divergência.

${ }^{34} \mathrm{Na}$ França, o repúdio provocado pelo regime de Vichy levou à adoção da proibição formal da delegação legislativa pela Constituição de 27/10/46 (art. 13: "Somente a Assembléia Nacional vota a lei. Ela não pode delegar este direito"). Posteriormente, o Conselho de Estado desenvolveu uma interpretação que ampliou a extensão do poder regulamentar, conciliando, assim, a vedação constitucional com a necessidade de se conferir ao Executivo a possibilidade de editar leis em sentido material (apud Caio Tácito, "As Delegações Legislativas e o Poder Regulamentar", RDA 34 (1953), p. 471). O Direito Público francês evoluiu no sentido de aceitar cada vez essa função legislativa do Executivo, até que os regulamentos autônomos foram consagrados pela Constituição de 1958 (Louis Favoreu (org.), Lê Domaine de la Loi e du Reglement, 2. ed., Paris: Econômica, 1981).

${ }^{35}$ Todos os exemplos foram retirados por Victor Nunes Leal do livro de José Afonso Mendonça de Azevedo, A Constituição Federal interpretada pelo Supremo Tribunal Federal, Rio, 1925, p. 63 (apud Vitor Nunes Leal, "Delegações Legislativas", ob. cit., p. 103).

36 "Delegações Legislativas", ob.cit., p. 95. 
Quem fala, aqui, não é o jurista, mas sim o cientista político, que critica o idealismo jurídico dos que combatiam a delegação legislativa. Em plena vigência da Constituição de 34, que vedava a delegação, o Parlamento aprovara quatro medidas que permitiram a Getúlio levar adiante a proposta golpista: a lei de segurança nacional, as emendas constitucionais, a criação do Tribunal de Segurança e a decretação do estado de guerra em todo o território nacional.

Além disso, segundo Victor Nunes Leal, havia uma segunda motivação para a campanha contra as delegações: o conservadorismo da Assembléia Constituinte, que tentava impedir a possibilidade de edição pelo Executivo de medidas legislativas rápidas no domínio econômico, eventualmente contrárias a seus interesses.

A prática da delegação legislativa nos EUA e na Inglaterra, para reformas conjunturais, mas com controle do Poder Legislativo, era outra evidência de que a hostilidade às delegações, predominante na Constituinte, era equivocada, exagerada, e geraria futuros problemas de governabilidade. Um verdadeiro anacronismo, tendo em vista a evolução constitucional de países tidos como democráticos.

Se parasse por aí, o texto de Victor Nunes Leal já teria sua importância mais que justificada. No entanto, sua contribuição vai mais além, quando ele passa a abordar a questão do conceito de regulamento em regimes que proíbem a delegação legislativa. Segundo o autor, a transição de um regime de delegação permitida para outro de delegação proibida levanta dois problemas.

O primeiro problema tem a ver com o próprio conceito de regulamento. Prevendo que a nova Constituição vedaria as delegações - lembre-se que Victor Nunes Leal escreve durante os trabalhos da Assembléia Constituinte - ele afirmou que ela manteria a competência do Presidente da República de expedir regulamentos para a fiel execução das leis. ${ }^{37}$ Para o autor, toda lei que pode ser regulamentada "contém em si mesma certa margem, por pequena que seja, de delegação ao poder executivo"38. Não se trata, obviamente, de delegação em sentido técnico, uma vez que inexiste ato formal de

\footnotetext{
${ }^{37}$ O que terminou acontecendo - cf. art. 87, I, da constituição de 1946.

38 "Delegações Legislativas", ob. cit., p. 99.
} 
transferência de competência. O que Victor Nunes Leal ressalta é que o resultado concreto é idêntico ao de uma verdadeira delegação, pois

“[...] se o Congresso pode regular um assunto nos seus mínimos detalhes e não o faz, deixando margem para o regulamento, temos, praticamente, uma situação que se assemelha à delegação, embora sem os requisitos técnicos que esta apresenta." 39

O autor mantém, nesse texto, a adesão à noção de que o regulamento é lei em sentido material (Duguit), portanto, ato de natureza normativa, sendo exclusivamente formal sua distinção em relação à lei, e a esta se subordinando.

Em regimes de delegação legislativa permitida, o conceito de regulamento é menos problemático porque ele pode trazer inovações expressa ou implicitamente permitidas pela lei. Entretanto, se a delegação é vedada, o conceito de regulamento é mais rígido, o poder regulamentar não pode ser usado para dissimular uma delegação.

Victor Nunes Leal enxerga, assim, uma contradição entre serem proibidas as delegações e ao mesmo tempo ser conservado o poder regulamentar do Executivo, já que

“[...O] regulamento, dado o seu papel de texto complementar da lei, envolve sempre a idéia de lacuna legislativa, o que equivale a dizer que contém sempre algum resíduo legislativo, uma certa medida de autoridade delegada." ${ }^{* 0}$

${ }^{39}$ Ibid., p. 100. É o próprio Victor Nunes Leal que retoma, em seu favor, a conhecida frase de Pontes de Miranda, segundo a qual as funções de legislar e de regular "não se podem considerar substancialmente distintas e rigorosamente delimitáveis. Do regular ao legislar, do legislar ao regular, nem sempre são claras as raias. Entre as duas competências medeia uma zona de fronteira, indecisa, mista, por ventura comum, em que as leis ora regulamentam, ora os regulamentos legislam" (Comentários à Constituição da República dos E. U. do Brasil, tomo I, p. 409-410, apud Leal ("Delegações legislativas", ob. cit., p. 101)). Entretanto, décadas depois, ao comentar a Constituição de 1967, nos termos da Emenda 1/69, Pontes de Miranda afirmou sua adesão à posição ortodoxa: "O decreto somente pode vincular ao ato ou à omissão se cabe na competência do Presidente da República, ou do Governador, ou de Prefeito a regra jurídica que se decreta. Dá-se o mesmo a propósito dos regulamentos: com êles se regula, não se legisla. Não se falou de instruções nem de avisos, nem de portarias. Com as instruções só se pode instruir. Com os avisos só se pode avisar. A portaria lembra a ordem ou mando ao porteiro, ou aos porteiros. Pensar-se que a Justiça pode atribuir à portaria o que só à lei é dado edictar é pensar-se que se possam esquecer de textos claríssimos da Constituição de 1967: 'Ninguém pode ser obrigado a fazer ou deixar de fazer alguma coisa senão em virtude de lei' (art. 153, § 2º." (Comentários à Constituição de 1967, com a Emenda $n^{\circ} 1$, de 1969, $2^{\mathrm{a}}$. ed. rev., t. V, São Paulo: RT, 1971, p. 3.).

40 “Delegações Legislativas", ob. cit., p. 102. 
A tendência seria, portanto, que esta contradição levasse os tribunais a resgatar a jurisprudência relativa à constituição de 1891, já referida supra. Tendo em vista o equívoco do constituinte, que proibiu a delegação legislativa, o Judiciário teria que adotar um conceito mais amplo de poder regulamentar.

O segundo problema decorrente da transição do regime de permissão para o de proibição das delegações consiste no seguinte: que destino teriam as delegações efetuadas na vigência da Carta de 37? Na solução proposta por Victor Nunes Leal, é necessário distinguir as delegações utilizadas daquelas não utilizadas no regime anterior. Já que a Carta de 37 permitia as delegações, a legislação delegada poderia ser recepcionada pela nova Constituição. Já as delegações não usadas seriam extintas com a entrada em vigor da nova Constituição.

Com relação aos decretos baixados no regime anterior (= legislação delegada), Victor Nunes Leal ressalta que sob a égide da nova ordem constitucional tais textos só poderiam ser alterados por regulamento nos trechos que trazem disposições propriamente regulamentares:

"Em outras palavras, se a lei delegou algumas matérias ao regulamento, o texto deste conterá, ao lado das disposições propriamente regulamentares, outras disposições com o caráter de legislação delegada. É indispensável fazer essa distinção. Se o executivo pode expedir regulamentos e alterá-los como bem the aprouver, mas não pode legislar por via de delegação, parece claro que, nos casos figurados, poderá o executivo modificar as disposições que forem propriamente regulamentares, mas não poderá tocar naquelas que tiverem o caráter de legislação delegada, embora umas e outras possam constar formalmente do mesmo ato (decreto, regulamento)." ${ }^{, 41}$

E neste ponto reaparece o problema do conceito de regulamento. O que são disposições "propriamente regulamentares", considerando que o regulamento é lei em sentido material? Para Victor Nunes Leal, tudo dependeria do conceito de poder regulamentar a ser construído pelo Poder Judiciário.

${ }^{41}$ Ibid., p. 107. 
É de enorme importância para a doutrina do Direito Público brasileiro o conjunto de reflexões que Victor Nunes Leal desenvolveu nos dois textos abordados, textos estes que são até costumeiramente citados pela doutrina contemporânea, mas de forma superficial. Como se não bastasse a ousadia do jurista do primeiro texto - dogmático, que insiste na natureza de lei em sentido material do regulamento, e se rebela contra a doutrina hegemônica da separação dos poderes --, é no segundo texto que ele mais surpreende, pois exerce um realismo jurídico que escandalizaria a doutrina liberal do Brasil contemporâneo, caso esta lhe prestasse a devida atenção.

O que o cientista político do segundo texto está tentando mostrar é que a consagração constitucional da proibição expressa e absoluta das delegações legislativas não terá efetividade, ou eficácia social. O Estado contemporâneo não funciona sem mecanismos de transferência de função legislativa para o Executivo. Se os constituintes, num gesto de reação contra a herança varguista, conseguissem - como conseguiram proibir as delegações, o processo político levaria à sua permissão por outro meio: a extensão do poder regulamentar via interpretação judicial - o que terminou ocorrendo.

Delegação legislativa e ampliação do poder regulamentar são, portanto, formas jurídicas distintas de se atingir o mesmo resultado: permitir que o Executivo produza lei em sentido material.

Expressão que é do conflituoso processo de construção histórica dos cânones de nosso direito público, o trabalho de Victor Nunes Leal nos fornece vigoroso exemplo de como uma análise realista das faculdades de estatuir pode contribuir para a reconstrução consistente da dogmática publicística ou para a própria reforma das instituições.

Nos casos analisados, o STF deparou-se com as opções apontadas por Victor Nunes Leal: ou se aceita a delegação, ou se amplia o poder regulamentar. É a mesma escolha que deve fazer a doutrina que não segue a ortodoxia da separação dos poderes. Como vimos, ela é discutida há mais de meio século por importantes nomes do Direito Público brasileiro. A sua percepção pelo STF foi mais clara no HC 30.355 do que nos seus julgados mais recentes. 
A ampliação do poder regulamentar passa necessariamente pela superação da concepção de regulamento enquanto mero instrumento de execução que não inova a ordem jurídica. Em outras palavras, faz-se necessário aprofundar um processo que já teve início: repensar os conceitos dogmáticos e as doutrinas do direito público que dirigem o sistema do direito brasileiro, com vistas ao controle democrático da capacidae normativa de conjuntura da burocracia reguladora.

A dogmática do direito público pode e deve ser transformada. Seus cânones e suas mais importantes noções revelam-se, na sua forma predominante hoje no Brasil, não somente irrealistas, mas prejudiciais para a própria democracia.

Ao chamar a atenção para o caráter histórico das noções jurídicas, Carré de Malberg referia a concepção de lei como conteúdo uma regra de direito, ou seja, preceito relativo à liberdade e à propriedade. Segundo esta concepção, somente é lei o preceito que traz modificação ou inovação no estatuto jurídico dos indivíduos, criando deveres ou direitos inéditos. Essa noção de lei encontra sua origem histórica no estabelecimento das monarquias constitucionais no continente Europeu, na primeira metade do século XIX. No sistema constitucional alemão de 1814 a 1830, por exemplo, matéria de lei é tudo que se refere à liberdade e à propriedade, restando para o monarca a competência para regulamentar a organização e o funcionamento internos dos serviços administrativos. Para essa doutrina, a generalidade não faz parte da essência da lei. Se uma lei autoriza o Poder Executivo a editar regras de direito, instituiu-se uma delegação de poder legislativo feita pelo Parlamento. Os regulamentos, que são editados pelo Executivo, podem então ser classificados em:

(1) regulamentos com características legislativas, ou seja, de regra de direito (Rechtsverordnungen);

(2) regulamentos que não criam direito novo para os indivíduos, vinculando somente a conduta dos funcionários da Administração na prestação de serviços (Verwaltungsverordnungen).

A evolução histórica da noção de lei, em termos esquemáticos, dá-se da lei enquanto regra geral (século XVIII) para a lei enquanto regra de direito (século XIX). O terceiro passo dessa evolução foi dado a partir do momento em que as constituições passaram a considerar como sendo lei todo e qualquer preceito editado pelo órgão 
legislativo, independentemente de seu conteúdo: qualquer preceito, ainda que não seja genérico e abstrato, e mesmo que não inove a ordem jurídica (criando direitos e deveres inéditos para os indivíduos), é considerado lei. Trata-se, obviamente, de uma concepção formal de lei - lei como produto do processo legislativo.

Nesse contexto é que surge a distinção entre lei em sentido formal e lei em sentido material, introduzindo um dualismo no conceito de lei. Lei em sentido formal é todo preceito editado pelo Legislativo (qualquer que seja seu conteúdo), enquanto a lei em sentido material - que pode ou não ser uma lei em sentido formal - é todo preceito que inova a ordem jurídica.

Como se verifica, a noção de lei durante três séculos seguidos é profundamente alterada, sem que as novas concepções eliminem as velhas. Como salienta Carré de Malberg $^{42}$, os autores continuam a reproduzir definições de lei nascidas em tradições passadas, ao mesmo tempo em que a tendência do direito público positivo tem sido de consagrar uma concepção formal de lei. A confusão conceitual, portanto, dá-se em dois planos: de um lado, entre doutrinadores; de outro, entre a doutrina e o direito positivo.

A reformulação das noções jurídicas dogmáticas precisa portanto ser orientada por uma compreeensão dos desafios de cada época histórica. Se levarmos a sério a idéia de que, na constituição-máquina, o poder normativo da burocracia pode ser visto como uma faculdade de estatuir, damos o primeiro passo para recuperar, como fez Victor Nunes Leal, o realismo que permitirá ao direito público enfrentar o desafio do déficit democrático da regulação financeira:

“[... C]omme toujours les faits sont plus forts que les constitutions; le pouvoir réglementaire s'etend constantement et un grand nombre de règlements apparaissent, qu'il est impossible de rattacher à l'exécution des lois. Ainsi il s'est formé à côté de la législation que l'on peut appeler réglementaire et qui a pour les particuliers, les administrateurs et les juges la même force obligatoire que les lois formelles." ${ }^{43}$

\footnotetext{
${ }^{42} \mathrm{Ob}$ cit, $\mathrm{n}^{\mathrm{o}} 11$.

${ }^{43}$ Léon Duguit, Les transformations du droit public, Paris: Librairie Armand Colin, p. 88.
} 
2. Para além do controle judicial: constituição-máquina e imaginação institucional

Em meio à recente reconstrução da democracia brasileira, os debates sobre delegação legislativa e poder regulamentar foram retomados sobre novas bases, sob a égide da Constituição de 1988. O que se pretendeu demonstrar com o breve registro do debate que tem caracterizado o direito público brasileiro é que a interpretação, ou mesmo a reformulação da atual Constituição pode ser enriquecida se levarmos a sério o que disseram autores como Victor Nunes Leal, bem como os debates que marcaram a história do direito público brasileiro. Percebe-se, assim, como muitos de nossos problemas atuais são, na realidade, velhos e recorrentes temas do Direito Público brasileiro.

O resgate desse debate, especialmente da forma como ele se desenvolveu em torno da Constituição de 46, pode ser útil para a compreensão da ordem constitucional brasileira pós-88. Guardadas as devidas proporções, o art. 25 do ADCT da atual Constituição, discutido no primeiro capítulo, equivale ao antigo $\S 2^{\circ}$ do art. 36 da Constituição de 1946. O debate sobre a vedação constitucional da delegação legislativa ressurge num contexto político e jurídico idêntico ao de 46: instauração de um regime democrático e promulgação de uma nova Constituição.

A atual Constituição confere ao Presidente da República autêntica função legislativa, mediante a edição de medidas provisórias e leis delegadas. A atribuição constitucional explícita dessas competências restringe a possibilidade de divergências quanto à sua interpretação, com as exceções notórias das polêmicas sobre a possibilidade de reedição de medidas provisórias (antes da Emenda e do controle judicial dos requisitos de urgência e relevância. $O$ fato é que a cultura jurídica brasileira já admite o exercício de função legislativa pelo Chefe do Executivo). ${ }^{44}$

O mesmo não acontece, entretanto, com os órgãos da Administração. No caso específico das autoridades monetárias, o Conselho Monetário Nacional (CMN) e o Banco Central (Bacen), vige no Brasil uma dissociação entre o discurso da maior parte da

${ }^{44}$ Clèmerson Merlin Clève, Atividade Legislativa do Poder Executivo no Estado Contemporâneo e na Constituição de 1988, São Paulo: RT, 1993. 
doutrina do Direito Público e a prática "profana" e "clandestina" da normatividade do sistema financeiro nacional. ${ }^{45}$

Todo o intricado debate sobre a competência normativa (com fundamento em delegação legislativa ou atribuição explícita ou implícita de poder regulamentar) de órgãos da Administração direta e indireta poderia pelo menos bastante reduzido, se a Constituição trouxesse regras claras sobre tema tão complexo.

O anteprojeto de Constituição de Fábio Konder Comparato ${ }^{46}$ atacou diretamente esse problema. Na Seção 5 do Capítulo $3^{\circ}$ do Título I, denominada "Os Órgãos Normativos Autônomos", lê-se o seguinte:

“Art. 107 - Lei complementar pode criar órgãos administrativos autônomos, dotados de poder normativo e de polícia, para regular a moeda e o crédito e outros setores determinados da ordem econômica e social.

"Parágrafo único - Além do poder normativo autônomo, exercido dentro dos limites fixados pela lei que os instituiu, a esses órgãos administrativos pode também ser atribuído, expressamente, o poder de regulamentar certas e determinadas leis.”

Mesmo sem resolver o problema dogmático - delegação legislativa ou atribuição de poder regulamentar -, a proposta de Comparato destitui essa discussão de efeitos práticos. O poder normativo "autônomo" dos órgãos administrativos igualmente autônomos está consagrado, mas dentro de limites fixados pela lei. A redação sugere a adoção pelo autor de uma distinção entre "poder normativo" e "poder regulamentar", como se este último não tivesse natureza normativa (poder de editar leis em sentido material). Outra imprecisão também deriva da alusão ao poder de polícia, como se o poder normativo não fosse também uma expressão deste último.

45 O mesmo já afirmara Bonifácio Fortes, em relação a órgãos como a Superintendência da Moeda e do Crédito (SUMOC) e o Instituto do Açúcar e do Álcool (IAA) ("Delegação legislativa”, ob. cit., p. 374). No mesmo sentido, Almiro do Couto e Silva refere as "formas veladas de delegação legislativa": "Nenhum de nós ignora o significado e o poder dos regulamentos, resoluções, circulares, portarias etc., pelas quais de um só golpe, como ocorre com as Resoluções do Conselho Monetário Nacional ou com as circulares do Banco Central, altera-se o desenho de importantíssimos setores da Nação. O problema, aliás, não é só nosso e encontra símile na maioria dos países democráticos do nosso tempo" ("Princípios da legalidade da Administração Pública e da segurança jurídica no Estado de Direito Contemporâneo", Revista de Direito Público 84 (1987), p. 52).

${ }^{46}$ Muda Brasil: uma Constituição para o desenvolvimento democrático, São Paulo: Brasiliense, 1986. 
Não obstante essas considerações, a proposta é inovadora no direito brasileiro. As motivações doutrinárias de sua formulação encontram-se melhor desenvolvidas em outros textos do autor. $^{47}$

Após diagnosticar as insuficiências e impropriedades da democracia liberal principalmente do processo legislativo clássico - para as grandes decisões de transformação econômica e social, Comparato alerta para a necessidade de intervenção estatal no domínio econômico mediante a edição de normas de conjuntura ou mesmo com caráter experimental. ${ }^{48}$

“Aqui, como alhures, quase todas as matérias referentes à moeda, ao crédito e ao mercado de capitais, ao sistema bancário e segurador, são reguladas por resoluções, instruções ou circulares editadas por órgãos administrativos formalmente autônomos. Nos Estados unidos, as independent regulatory comissions tiveram reconhecidos, pela Suprema Corte, poderes "quase-legislativos" e "quasejudiciais", além do tradicional poder de polícia. No Brasil, nem mesmo chegou a ser levada aos tribunais a questão constitucional de se saber se a criação por lei desses órgãos normativos autônomos, no âmbito administrativo, não feriria o princípio de que, salvo as exceções previstas na própria Constituição, 'é vedado a qualquer dos Poderes delegar atribuições' (art. $6^{\circ}$ e parágrafo único)". 49

$\mathrm{O}$ aludido $\S$ único do art. $6^{\circ}$ da EC $1 / 69$ provocava os mesmos questionamentos do $\S 2^{\circ}$ do art. 36 da Constituição de 46, hoje suscitados pelo art. 25 do ADCT da atual Constituição. A regra da vedação da delegação legislativa é declaração inócua nas constituições de fachada e empecilho ao funcionamento democrático e eficiente do Estado nas constituições de sociedades democráticas. A proposta de Comparato rompe com a tradição brasileira de "recalque" contra as delegações, redesenhando as instituições.

Todavia esta ruptura é acompanhada de uma preocupação com a garantia de democratização dos órgãos e de seus processos decisórios. De acordo com o art. 109 do anteprojeto, "a lei assegurará, sempre que possível, a publicidade do processo normativo".

\footnotetext{
${ }^{47}$ Fábio Konder Comparato, Muda Brasil: uma Constituição para o desenvolvimento democrático, ob. cit. .

${ }^{48}$ Ibid., p. 404.

${ }^{49}$ Ibid., p. 405.
} 
Os órgãos autônomos e seu poder normativo igualmente autônomo estariam submetidos a um regime de publicidade relativa, uma fórmula que viabiliza ações estatais que eventualmente possam exigir sigilo, como é comum na regulação e supervisão do sistema financeiro. O que é fundamental é que este regime de publicidade relativa ou seletiva é traçado pela lei, e não pelo próprio órgão.

A composição dos órgãos autônomos deriva de uma fórmula já consagrada: indicação pelo Presidente da República e aprovação do Congresso Nacional. Estes órgãos não seriam, porém, estritamente governamentais, pois pelo menos um terço dos membros efetivos deveria ser composto de "pessoas indicadas pelos grupos econômicos e sociais do setor em que o órgão normativo exercerá sua atuação" (art. 108, II), ou seja, representantes da sociedade civil. A autonomia é garantida por duas outras regras: (a) Ministros de Estado, funcionários públicos não efetivos e funcionários demissíveis ad nutum não podem compor o órgão autônomo; (b) a instituição de mandato, sendo admitida a recondução para o período subseqüente somente uma vez (art. 108, I e III, respectivamente).

Os órgãos normativos autônomos encontram-se inseridos numa proposta de inovação institucional muito mais ampla. Comparato propõe uma reformulação da tradicional separação de poderes, com vistas à formulação de um planejamento democrático. Assim, assumindo-se a distinção entre a função de desenvolver políticas a longo prazo e a de administração ordinária dos negócios correntes, aquela primeira seria confiada a órgãos de planificação: a Superintendência Nacional de Planejamento e o Conselho Nacional de Planejamento. A primeira teria um caráter mais técnico, com um presidente com mandato de seis anos, e elaboraria os planos nacionais e regionais de desenvolvimento, com os respectivos orçamentos-programa. O Conselho, por sua vez, seria um órgão político, composto de representantes de grupos sociais e categorias profissionais. Os planos deveriam ser aprovados pelo Congresso e por órgãos políticos regionais. Nesse arranjo, os órgãos normativos autônomos, como o Conselho Monetário Nacional, estariam juridicamente vinculados ao plano.

Comentando a proposta, Luiz Werneck Vianna questionou o corporativismo da proposta, que parece diminuir o papel dos partidos políticos e do Presidente da República, que se tornaria um mero executor de um plano que ele não elaborou, e com o qual pode eventualmente não ter qualquer afinidade ideológica. Subjacente à proposta está uma 
concepção de burocracia iluminada, e uma noção de corporação não medieval, não fascista, mas de natureza burguesa. ${ }^{50}$

Não é intenção do presente ensaio aprofundar o exame da proposta de Comparato, mas simplesmente mostrar que há formas e arranjos institucionais alternativos em que as burocracia reguladora do mercado financeiro poderia se inserir.

Têm sido longas, repetitivas e improdutivas, no Direito Público brasileiro, as querelas dogmáticas hermenêuticas acerca da delegação legislativa e do poder regulamentar. As transições democráticas, como profetizou Victor Nunes Leal, não foram períodos de grande ousadia institucional. No que se refere à configuração constitucional da burocracia reguladora, 1988 repetiu 1946.

Entretanto, não temos alternativa. Diante da implausibilidade de uma reforma constitucional ousada nos próximos anos, toda e qualquer mudança só poderá vir da militância doutrinária ou da jurisprudência constitucional. Somente pela rejeição do "fetichismo institucional" $"$ da doutrina clássica da separação dos poderes, ou seja, a relação necessária que ela vê entre ideais políticos e configurações intitucionais, é que o controle judicial da burocracia poderá contribuir para a democratização da regulação financeira no Brasil, sem que precise bloquear a ação da burocracia que zela, em última instância, pela coesão social.

\footnotetext{
${ }^{50}$ Cf. Nilo Odália (org.), Brasil, o desenvolvimento ameaçado: perspectivas e soluções, São Paulo: Unesp, 1989, p. 99.

${ }^{51}$ Cf. Roberto Mangabeira Unger, Social theory: its situation and its task, Cambridge: Cambridge University Press, 1987, pp. 200 e ss. Para exemplos instigantes de imaginação institucional e experimentalismo democrático que escandalizariam nossos doutrinadores liberais, ver Bruce Ackerman, "The new separation of powers", ob. cit; Charles Sabel e Michael Dorf, "A constitution of democratic experimentalism", Columbia Law Review 98 (1998), pp. 268-473; Roberto Mangabeira Unger, False necessity: anti-necessitarian social theory in the service of radical democracy, Cambridge: Cambridge University Press, 1987, pp. 449-480.
} 


\section{BIBLIOGRAFIA}

Ackerman, Bruce. “The new separation of power". Harvard Law Review 113 (2000): 633729.

Akerlof, George. "The market for 'lemons': quality, uncertainty and the market mechanism". Quarterly Journal of Economics 84 (1970): 488-500.

Aglietta, Michel. Macroeconomie financiére. Paris: Editions La Decouverte, 1995.

. Régulation et crises du capitalisme. nouvelle édition revue et corrigée, Paris: Odile Jacob, 1997.

Aglietta, Michel, / Orléan, André. La monnaie entre violence et confiance. Paris: Odile Jacob, 2002.

Alessi, Renato. Princìpi de Diritto Amministrativo. v. 1, 4. ed., Milão: Giuffrè, 1978.

Alexy, Robert. Teoría de los derechos fundamentales. Madrid: Centro de Estudios Constitucionales, 1993.

Althusser, Louis. Montesquieu: la Politique et l'Histoire. 7. ed., Paris: Quadrige/PUF, 1992.

Aragão, Alexandre. "As agências reguladoras independentes e a separação de poderes uma contribuição da teoria dos ordenamentos setoriais". Revista dos Tribunais 786 (2001): 11-56.

. "Os ordenamentos setoriais e as agências reguladoras independentes", Revista de Direito da Associação dos Procuradores do Novo Estado do Rio de Janeiro IV (2000): 87-136.

Arantes, Rogério Bastos. Judiciário e política no Brasil. São Paulo: Idesp/Sumaré/Educ/Fapesp, 1997.

Ataliba, Geraldo. "Delegação Normativa (Limites às Competências do CMN e do BACEN)". Revista de Direito Público 98 (1991): 50-69.

. "Poder Regulamentar do Executivo". Revista de Direito Público 57-58 (1981): 184208.

Bandeira de Mello, Celso Antônio. Curso de Direito Administrativo. 12. ed., São Paulo : Malheiros, 2000.

. "Regulamento e Princípio da Legalidade". Revista de Direito Público 96 (1990): 4250.

Barroso, Luís Roberto. "Apontamentos sobre o princípio da legalidade”, in: Temas de direito constitucional. Rio de Janeiro: Renovar, 2001: 165-188.

. "Disposições Constitucionais Transitórias (natureza, eficácia e espécie), Delegações Legislativas (validade e extensão), Poder Regulamentar (conteúdo e limites)". Revista de Direito Público 23 (1990): 69-80.

- "Princípio da legalidade. Delegações legislativas. Poder regulamentar. Repartição constitucional das competências legislativas", São Paulo: 1996, disponível [on-line] in http://www.forense.com.br [29-05-1996].

Beetham, David. Bureaucracy. 2. ed., Minneapolis: University of Minnesota Press, 1996.

Boyer, Robert / Saillard, Yves Saillard (dir.). Théorie de la régulation: l'état des savior. nouvelle édition complétée, Paris: La Decouverte, 2002.

Bruna, Sérgio Varella. Agência reguladoras: poder normativo, consulta pública, revisão judicial. São Paulo: Revista dos Tribunais, 2003.

Camargo, Margarida Maria Lacombe (org.). 1988-1998: uma década de Constituição. Rio de Janeiro: Renovar, 1999. 
Cappelletti, Mauro / Cohen, William. Comparative constitutional law: cases and materials. Charlottesville: The Michie Company, 1979.

Carré de Malberg, Raymond. La Loi, Expression de la Volonté Générale. Paris: Librairie du Recueil Sirey, 1931.

Chesnais, François (coord.). A mundialização financeira. São Paulo: Xamã, 1998.

Cheek, James H. "Approaches to market regulation", in: Fidelis Oditah (ed.), The future for the global securities market: legal and regulatory aspects. Oxford: Clarendon Press, 1996: 243-245.

Clevè, Clèmerson Merlin. Atividade Legislativa do Poder Executivo no Estado Contemporâneo e na Constituição de 1988. São Paulo: Revista dos Tribunais, 1993.

. Medidas Provisórias. 2. ed., São Paulo: Max Limonad, 1999.

_. A fiscalização abstrata da constitucionalidade no Direito brasileiro. 2. ed., São Paulo: Revista dos Tribunais, 2000.

Comparato, Fábio Konder. Muda Brasil: uma Constituição para o desenvolvimento democrático. São Paulo: Brasiliense, 1986a.

"Um quadro institucional para o desenvolvimento democrático", in: Helio Jaguaribe et. al., Brasil, sociedade democrática. 2. ed., Rio de Janeiro: José Olympio, 1986b: 393432.

"Precisões sobre os conceitos de lei e de igualdade jurídica". Revista dos Tribunais 750 (1998): 11-19.

Couto e Silva, Almiro do. "Princípios da legalidade da Administração Pública e da segurança jurídica no Estado de Direito contemporâneo". Revista de Direito Público 84 (1987): 46-63.

Coutu, Michel. "Rationalité juridique et légitimité du droit chez Max Weber", in: Pierre Lascoumes (dir.), Actualité de Max Weber pou la sociologie du droit. Paris: LGDJ, 1995: pp. 211-219.

De Chiara, José Tadeu. Moeda e Ordem Jurídica, Tese de Doutoramento, São Paulo: Faculdade de Direito da USP, 1986.

Duarte, Clenício da Silva. “Os Regulamentos Independentes”. Revista de Direito Público 16 (1951): 89-95.

Duguit, Léon. Les transformations du droit public, Paris: Libraire Armand Colin, 1921.

Dworkin, Ronald. "Hard cases". Harvard Law Review 88 (1975): 1057.

. Taking rights seriously. Cambridge: Harvard University Press, 1977.

Eisenmann, Charles. "L'Esprit des Lois et la Séparation des Pouvoirs", in: Cahiers de Philosophie Politique (Montesquieu). Bruxelas: Ousia, 1985: 3-34.

. "La Penséé Constitutionelle de Montesquieu", in: Cahiers de Philosophie Politique (Montesquieu). Bruxelas: Ousia, 1985: 35-66.

Eizirik, Nelson (org.). Instituições financeiras e mercado de capitais: jurisprudência. Tomo 1, v. 1, Rio de Janeiro: Renovar, 1996a.

Instituições financeiras e mercado de capitais: jurisprudência. Tomo 1, v. 1, Rio de Janeiro: Renovar, 1996b.

Instituições financeiras e mercado de capitais: jurisprudência. Tomo 2, v. 1, Rio de Janeiro: Renovar, 1998a.

Instituições financeiras e mercado de capitais: jurisprudência. Tomo 2, v. 2, Rio de Janeiro: Renovar, 1998b.

Elster, Jon. "Constitutional courts and central banks: suicide prevention or suicide pact?". East European Constitutional Review 3 (1994): 66.

Fagundes, Miguel Seabra. "Reformas essenciais ao aperfeiçoamento das instituições políticas brasileiras". Revista Forense 163 (1956): 13. 
Falcão, Joaquim. "Repercussão geral”, Folha de São Paulo, 18.04.2004, p. A-3.

Faria, José Eduardo. Eficácia jurídica e violência simbólica: o direito como instrumento de transformação social. São Paulo: Edusp, 1988.

. Direito e economia na democratização brasileira. São Paulo: Malheiros, 1993.

. O Direito na economia globalizada. São Paulo: Malheiros, 1999.

Favoreu, Louis (org.). Le Domaine de la Loi e du Reglement. 2. ed., Paris: Economica, 1981.

Ferraz, Sérgio. Três Estudos de Direito: Desapropriação de Bens Públicos; o Prejulgado Trabalhista em Face da Constituição; Regulamento. São Paulo: Revista dos Tribunais, 1977.

Ferraz Jr., Tércio Sampaio. Função social da Dogmática Jurídica. São Paulo: Max Limonad, 1998.

. "Agências Reguladoras: legalidade e constitucionalidade". Revista Tributária e de Finanças Públicas 35 (2000): 143-158.

Ferreira, Carlos Kawall / Freitas, Maria Cristina Penido de / Schwartz, Gilson. "Formato institucional do sistema monetário e financeiro: um estudo comparado", in: Marcos Antonio Macedo Cintra e Maria Cristina Penido de Freitas (org.), Transformações institucionais dos sistemas financeiros: um estudo comparado. São Paulo: Fapesp/Fundap, 1998: 113-144.

Figueiredo, Argelina / Limongi, Fernando. "O Congresso e as Medidas Provisórias: Abdicação ou Delegação?”. Novos Estudos Cebrap 47 (1997): 127-154.

Executivo e Legislativo na nova ordem constitucional. Rio de Janeiro: FGV/FAPESP, 1999.

Fiori, José Luís. "Estados, moedas e desenvolvimento”, in: José Luís Fiori (org.), Estados e moedas no desenvolvimento das nações. Petrópolis: Vozes, 1999.

Fortes, Bonifácio. "Delegação legislativa". Revista de Direito Administrativo 62 (1960): 353.

. “O Poder Regulamentar”. Revista Forense 199 (1962): 371-378.

Freund, Julien. "La rationalisation du droit selon Max Weber". Archives de philosophie du Droit 31 (1981).

Garten, Helen A. US Financial Regulation and the Level Playing Field. New York: Palgrave, 2001.

Gasparian, Fernando (org.). A luta contra a usura - o limite constitucional dos juros anuais de $12 \%$ está em vigor. São Paulo: Graal, s/d.

Giannini, Massimo Severo. Diritto Pubblico dell'Economia. 33 . ed. Roma: Il Mulino, 1989.

Goodhart, Charles et al. Financial regulation: why, how and where now? London/New York: Routledge, 1998.

Goodhart, Charles / Schoenmaker, Dirk. "Should the functions of monetary policy and banking supervision be separated?". Oxford Economic Papers 47-4 (1995): 539560.

Grau, Eros Roberto. "Capacidade Normativa de Conjuntura", in: Enciclopédia Saraiva de Direito. v. 13, São Paulo: Saraiva, 1977: 48-50.

. "Notas sobre o ordenamento jurídico dos preços". Revista da Faculdade de Direito da UFMG 22 (1979): 155.

. "Os modelos de direito formal e de direito moderno e a dupla desestruturação do direito", in: $O$ direito posto e o direito pressuposto, São Paulo: Malheiros, 1996: 64-82. 
- "Crítica da 'separação dos poderes': as funções estatais, os regulamentos e a legalidade no Direito brasileiro, as leis-medida", in: O Direito Posto e o Direito Pressuposto. São Paulo: Malheiros, 1996: 167-199.

. La doppia destrutturazione del diritto. Milano: Unicopli, 1996.

. A ordem econômica na Constituição de 1988. São Paulo: Malheiros, 2000.

Ensaio e discurso sobre a interpretação/aplicação do direito. São Paulo: Malheiros, 2002.

Guastini, Ricardo. "Michel Troper sur la fonction juridictionnelle". Droits - Revue Française de Philosophie et de Culture Juridiques 37 (2003): 111-122.

Guttman, Robert. How Credit-Money Shapes the Economy: the United States in a Global System. Armonk, New York/London, England: M. E. Sharpe, 1994.

Gwyn, W. B. The meaning of the separation of powers: an analysis of the doctrine from its origin to the adoption of the United States Constitution. New Orleans: Tulane University, 1965.

Habermas, Jürgen. The theory of communicative action. 2 v., Boston: Beacon Press, 1987. Between facts and norms. Cambridge: MIT, 1997.

The inclusion of the other: studies in political theory. edited by Ciaran Cronin and Pablo De Greiff, Cambridge/Massachusetts: The MIT Press, 1998.

Hart, Herbert L. A. The concept of law. 2. ed., London: Oxford University Press, 1997.

Ihering, Rudolf von. Law as means to an end. trad. Isaac Husik. Boston: The Boston Book Company, 1913.

Joerges, Christian / Vos, Ellen (ed.). EU committees: social regulation, law and politics, Oxford: Hart Publishing, 1999.

Kelsen, Hans. Quien debe ser el defensor de la Constitución? trad. R. J. Brie. Madrid: Editorial Tecnos, 1995.

Teoria Geral do Direito e do Estado. trad. Luis Carlos Borges. São Paulo: Martins Fontes, 1998.

Kennedy, Duncan. A critique of adjudication (fin de siècle). Cambridge/Massachusetts: Harvard University Press, 1997.

Kugelmas, Eduardo. "Pimenta Bueno, o jurista da Coroa", in: Direito Público e análise da Constituição do Império. São Paulo: Ed. 34, 2002: 19-49.

Leães, L. G. Paes de Barros. Mercado de Capitais \& Insider Trading. São Paulo: Revista dos Tribunais, 1982.

Leal, Victor Nunes. "Delegações Legislativas". Revista de Direito Administrativo 5 (1946): 377-384.

. "Lei e Regulamento". Revista de Direito Administrativo 1 (1945): 371-375.

Problemas de Direito Público. Rio de Janeiro: Forense, 1960.

Leiter, Brian. "Legal realism, hard positivism, and the limits of conceptual analysis", in: Jules Coleman (ed.), Hart's postscript: essays on the Postscript to The Concept of Law. London: Oxford University Press, 2001: 355-370.

Llewellyn, David. "The economic rationale for financial regulation", FSA Occasional Paper, London, 1999.

Loewenstein, Karl. Teoria de la Constitución. Barcelona: Ariel, 1986.

Lopes, José Reinaldo de Lima. "Judiciário, democracia, políticas públicas". Revista de Informação Legislativa 122 (1994): 255-265.

Macey, Jonathan. "The business of banking: before and after Gramm-Leach-Bliley Act". Journal of Corporation Law 25 (2000): 691-722.

Mangabeira, João (rel.). Estudos constitucionais: Poder Legislativo. Rio de Janeiro: FGV/INDIPO, 1956. 
Martins, Ives Gandra. “A constituição e as agências regulatórias”, Valor Econômico, 31.05.2001, p. B-2.

Mendes, Gilmar Ferreira. "Lei 9868/99: processo e julgamento da ação direta de inconstitucionalidade e da ação declaratória de constitucionalidade do Supremo Tribunal Federal", Teresina, 2000, disponível [on-line] in http://www1.jus.com.br/doutrina/texto.asp?id=130 [29-01-2004].

Mesquita, José Ignácio Botelho. "O desmantelamento do sistema brasileiro de controle de constitucionalidade". Revista da Pós-graduação da Faculdade de Direito da Universidade de São Paulo 5 (2002): 9-19.

Mommsen, Wolfgang. The age of bureaucracy. London: Harper \& Row, 1974.

. "Max Weber on bureaucracy and bureaucratization: threat to liberty and instrument of creative action", in: The political and social theory of Max Weber. Chicago: The University of Chicago Press, 1989: 109-120.

Montesquieu, De L'Esprit des Lois, 2 vols., Paris: Garnier-Flammarion, 1979.

. O espírito das leis. trad. Fernando Henrique Cardoso e Leôncio Martins Rodrigues, São Paulo: Editor Víctor Civita, 1973.

Moreira, Egon Bockmann. "Conselho Monetário Nacional, Banco Central do Brasil e Comissão de Valores Mobiliários: considerações acerca de sua natureza jurídica, em face das chamadas 'Agências Administrativas"'. Revista de Direito Bancário e do Mercado de Capitais 6 (1999): 106-122.

Moreira Neto, Diogo de Figueiredo. "Agências reguladoras (descentralização e deslegalização)", in: Mutações do Direito Administrativo. 2. ed., Rio de Janeiro: Renovar, 2001: 149-184.

Müller, Friedrich. Discours de la méthode juridique. trad. Olivier Jouanjan. Paris: PUF, 1996.

Nonet, Philippe / Selznick, Philip. Law and society in transition: toward responsive law. 2. ed., New Brunswick: Transaction Publishers, 2001.

Nunes, Castro. “Delegação de poderes". Revista Forense 137 (1951): 5-8.

Nunes, Simone Lahorgue. Os fundamentos e os limites do poder regulamentar no âmbito do mercado financeiro. Rio de Janeiro: Renovar, 2000.

Odália, Nilo (org.). Brasil, o desenvolvimento ameaçado: perspectivas e soluções. São Paulo: Unesp, 1989.

Oliveira Vianna, Francisco José. “O problema da delegação de poder”. Revista Forense 72 (1937): 221-227.

Page, Alan. "Regulating the regulator - a lawyer's perspective on accountability and control”, in: Eilís Ferran / Charles Goodhart (eds.), Regulating financial services and markets in the twenty first century. Oxford Portland/Oregon: Hart Publishing, 2001: 127-149.

Piçarra, Nuno. A Separação dos Poderes como Doutrina e Princípio Constitucional: um Contributo para o Estudo das suas Origens e sua Evolução. Coimbra: Coimbra Ed., 1989.

Pimenta Bueno, José Antonio. Direito Público Brasileiro e análise da Constituição do Império. Rio de Janeiro: Ministério da Justiça e Negócios Interiores, 1957.

Polanyi, Karl. "The Economy as instituted process", in: Mark Granovetter and Richard Swedberg, The sociology of economic life. Oxford: Westview Press, 1992: 29-51.

The Great Transformation: the political and economic origins of our time. $2^{\text {nd }}$ ed. Boston: Beacon Press, 2001.

Pontes de Miranda. Comentários à Constituição de 67, com a Emenda $n^{\circ} 1$, de 69. Tomo V, 2. ed., rev., São Paulo: Revista dos Tribunais, 1971. 
Quintão, Geraldo Magela da Cruz. "Parecer da Advocacia Geral da União". Revista de Direito Bancário e do Mercado de Capitais 1 (1998): 152-159.

Rodrigues, Leda Boechat. História do Supremo Tribunal Federal. 4 v. Rio de Janeiro: Ed. Civilização Brasileira, 1991.

Rose-Ackerman, Susan. "American administrative law under siege: is Germany a model?". Harvard Law Review 107 (1994): 1279-1302.

Rosenn, Keith. "Judicial review in Brazil: developments under the 1988 Constitution". Southwestern Journal of Law and Trade in the Americas 7 (2000): 291-319.

Schluchter, Wolfgang. The Rise of Western Rationalism: Max Weber's Developmental History. Berkeley/Los Angeles/London: University of California Press, 1985.

Seabra Fagundes, Miguel. "Reformas essenciais ao aperfeiçoamento das instituições políticas brasileiras". Revista Forense 163 (1956): 9-21.

Silva, Carlos Medeiros. "O Poder Regulamentar e sua Extensão". Revista Forense 130 (1950): 339-341.

. "O poder regulamentar no direito comparado". Revista de Direito Administrativo 30 (1952): 28-33.

Siqueira Castro, Carlos Roberto de. O Congresso e as Delegações Legislativas. Rio de Janeiro: Forense, 1986.

Sola, Lourdes et. al. "Banco central, autoridade política e governabilidade democrática", in: Lourdes Sola/Eduardo Kugelmas/Laurence Whitehead (orgs.), Banco central: autoridade política e democratização - um equilíbrio delicado. Rio de Janeiro: FGV, 2002, pp. 113-159.

Stiglitz, Joseph / Greenwald, Bruce / Weiss, Andrew. "Information imperfections in the capital market and macroeconomic fluctuations". American Economic Review 74 (1984): 194-199.

Sundfeld, Carlos Ari. "Serviços públicos e regulação estatal: introdução às agências reguladoras", in: Carlos Ari Sundfeld (coord.), Direito Administrativo Econômico. São Paulo: Malheiros, 2000: 17-38.

Tácito, Caio. “As Delegações Legislativas e o Poder Regulamentar". Revista de Direito Adminsitrativo 34 (1953): 471-473.

Teubner, Gunther. "Juridification: concepts, aspects, limits, solutions", in: Gunther Teubner (ed.), Juridification of social spheres: a comparative analysis in the areas of labor, corporate, antitrust and social welfare law. Berlin: Walter de Gruyter, 1987, pp. 3-48.

Troper, Michel. "Charles Eisenmann contre le Mythe de la Séparation des Pouvoirs". Cahiers de Philosophie Politique (Montesquieu). Bruxelas: Ousia, 1985: 67-79.

. La Séparation des Pouvoirs et l'Histoire Constitutionelle Française. Paris: LGDJ, 1980.

"Actualité de la séparation des pouvoirs", in: Pour une théorie juridique de l'État. Paris: PUF, 1996: 225-236.

. La théorie du droit, le droit, l'État. Paris: PUF, 2001.

Trubek, David. "Max Weber's tragic modernism and the study of Law in society". Law \& Society Review 4 (1986): 573-598.

Velloso, Carlos Mário da Silva. "Do Poder Regulamentar”. Revista de Direito Público 65 (1983): 339-341.

. "Delegação Legislativa - a Legislação por Associações", in: Temas de Direito Público. Belo Horizonte: Del Rey, 1997: 40-48.

Venâncio Filho, Alberto. A Intervenção do Estado no Domínio Econômico. Rio de Janeiro: FGV, 1968. 
Vianna, Francisco José Oliveira. "O problema da delegação de poder”. Revista Forense, 72 (1937): 224.

Vianna, Luiz Werneck et al. A judicialização da política e das relações sociais no Brasil. Rio de Janeiro: Revan, 1999.

Vianna, Maria Lúcia Teixeira Werneck. A Administração do "Milagre": o Conselho Monetário Nacional -- 1964-1974. Petrópolis: Vozes, 1987.

Vieira, Oscar Vilhena. Supremo Tribunal Federal: jurisprudência política. São Paulo: Revista dos Tribunais, 1994.

Vile, Maurice J. C. Constitutionalism and the Separation of Powers. Oxford: Clarendon Press, 1967.

VVAA. Vários artigos e pareceres, Revista de Direito Público 88 e Revista de Direito Público 89.

Weber, Max. Economy and Society: an outline of interpretative sociology. v. 2, edited by Guenther Roth and Claus Wittich, New York: Bedminster Press, 1968.

"Burocracia", in: C. Wright Mills and Hans Gerth (orgs.), Max Weber: Ensaios de Sociologia. trad. Waltensir Dutra. Rio de Janeiro: Guanabara Koogan, 1982: 229282. 


\section{RÉSUMÉ}

La régulation financière, spécialement la régulation bancaire, a un rôle central dans l'organisation de la vie sociale. Les techniques régulatrices modernes, hautement sophistiquées, sont le résultat de décennies d'évolution. Elles exigent des techniciens spécialisés, des budgets spécifiques et une complexe structure institutionnelle. Plus encore : dans le but de promouvoir la régulation prudentielle et la prévention du risque systémique, les régulateurs nécessitent de vastes pouvoirs normatifs.

L'attribution de ces compétences à des institutions qui n'ont pas été légitimées par le vote est considérée par certains auteurs comme une sorte d'anomalie dans le droit constitutionnel. Pour d'autres, au contraire, elle est un élément nécessaire de la configuration institutionnelle de l'État Régulateur contemporain. C'est à ce point que se croisent les débats sur le procès de bureaucratisation da la vie sociale et sur le développement des canons du droit occidental, spécialement la doctrine de la séparation des pouvoirs.

La juridicisation des sphères sociales suscite le thème du déficit démocratique de la formulation de politiques pour la bureaucratie. Cette thèse doctorale développe la prémisse normative selon laquelle le contrôle juridictionnel est nécessaire pour garantir la légitimité démocratique du procès administratif. Comme le citoyen commun ne dispose ni de connaissances techniques, ni des moyens matériels nécessaires pour accompagner le procès de prise de décisions, le contrôle juridictionnel devrait fonctionner comme un mécanisme de contrôle démocratique de la régulation financière.

Cette thèse analyse ce déficit démocratique à partir de la jurisprudence constitutionnelle du Suprême Tribunal Fédéral (STF) relative à la séparation des pouvoirs et aux disputes doctrinaires sur la délégation législative et le pouvoir réglementaire. Les études de cas, concentrées sur le système financier, démontrent que l'action du STF n'est pas en train de garantir d'une façon adéquate un équilibre entre la rationalité technocratique et les exigences normatives d'une démocratie délibérative. 


\begin{abstract}
Financial regulation, specially banking regulation, plays a central role in the organization of social life. The current regulatory techniques, highly sophisticated, are the result of decades of evolution. They require well-trained public officials, specific budgets and a complex institutional framework. Moreover, in order to carry on the systemic and prudential regulations, regulators need broad rule-making powers.
\end{abstract}

The assignment of such authority to non-majoritarian bodies is considered by some authors as a sort of anomaly in Constitutional Law. To others, it is seen as a necessary element of the institutional design of the contemporary Regulatory State. This is the stage where the debate about the process of bureaucratization of social life meets the intellectual concern about the current developments of western public law, namely the issue of the separation of powers.

The juridification of the social spheres brings the issue of the democratic deficit of bureaucratic policymaking. Since ordinary citizens lack the expertise as well as the material and financial resources which are necessary to monitor the decision-making process, this dissertation develops the normative assumption that judicial review is necessary to ensure the democratic legitimacy of the administrative process.

The dissertation analyses that democratic deficit from the viewpoint of the constitutional jurisprudence of the Brazilian Supreme Court (Supremo Tribunal Federal STF) regarding separation of powers, the rule-making authority of Brazilian nonmajoritarian bodies and the doctrinal disputes about legislative delegation. The case studies show that the judicial review by STF has in practice rejected the Brazilian public law nondelegation doctrine, but has done it in a way that does not strike a balance between technocratic rationality and the normative claims of deliberative democracy. 